Christoph Arndt

\title{
The Electoral Consequences of Third Way Welfare State Reforms
}

SOCIAL DEMOCRACY'S TRANSFORMATION AND ITS

Political Costs 
THE ELECTORAL CONSEQUENCES OF THIRD WAY WELFARE STATE REFORMS 


\section{CHANGING WELFARE STATES}

For quite some time, a key finding and theoretical puzzle in comparative welfare state research was welfare states' remarkable stability. In the last decade, however, it has become clear that advanced welfare states were (far) less immovable than they seemed at first. In fact, speaking of changing welfare states captures much better the actual reforms that were taking place. This series is about the trajectories of those changes. Have there been pathbreaking welfare innovations or are the changes incremental instead? Are welfare states moving in a similar or even convergent direction, or are they embarking on divergent trajectories of change? What new policies have been added, by which kind of political actors, how, and with what consequences for competitiveness, employment, income equality and poverty, gender relations, human capital formation, or fiscal sustainability? What is the role of the European Union in shaping national welfare state reform?

This series answers these and related questions by studying the socioeconomic, institutional and political conditions for welfare state change, its governance, and its outcomes across a diverse set of policy areas. The policy areas can address traditional "old" social risks like old age, unemployment, sickness (including the health care system), disability and poverty and inequality in general, or "new" social risks that have arisen mainly due to post-industrialization, such as reconciling work and family life, non-standard employment, and low and inadequate skills. In addition to focusing on the welfare state more narrowly defined, the series also welcomes publication on related areas, such as the housing market. The overriding objective of the series is tracing and explaining the full trajectories of contemporary welfare state change and its outcomes.

\section{EDITORS OF THE SERIES}

Gøsta Esping-Andersen, University of Pompeu Fabra, Barcelona, Spain Brian Burgoon, University of Amsterdam, the Netherlands Anton Hemerijck, VU University Amsterdam, the Netherlands Barbara Vis, VU University Amsterdam, the Netherlands Kimberly Morgan, George Washington University, Washington, USA Herman van der Werfhorst, University of Amsterdam, the Netherlands 


\section{The Electoral Consequences of Third Way Welfare State Reforms}

Social Democracy's Transformation and its Political Costs

Christoph Arndt 
Cover illustration: Johann Peter Hasenclever, Arbeiter vor dem Magistrat

Cover design: Crasborn Grafisch Ontwerpers BNo, Valkenburg a/d Geul Lay-out: $\mathrm{V}_{3}$-Services, Baarn

ISBN 9789089644503

e-ISBN 9789048517213 (pdf)

e-ISBN 978904851722 o (ePub)

NUR $\quad 754$

@ Christoph Arndt / Amsterdam University Press, Amsterdam 2013

All rights reserved. Without limiting the rights under copyright reserved above, no part of this book may be reproduced, stored in or introduced into a retrieval system, or transmitted, in any form or by any means (electronic, mechanical, photocopying, recording or otherwise) without the written permission of both the copyright owner and the author of the book. 


\section{Table of Contents}

\section{List of Tables 9}

\section{List of Figures 13}

\section{List of Abbrevations 15}

\section{Preface 19}

$1 \quad$ Introduction 23

1.1 Empirical puzzle 23

1.2 The arguments in brief 27

1.3 Structure of the book 29

\section{Theoretical Background 33}

2.1 The political-economic and societal background to Third Way policies 33

Social Democracy's transformation towards the Third Way 35

2.2 Social policy and the welfare state as a base for social democratic alignment 37

2.3 Welfare state reform as a catalyst for partisan dealignment 41 Comparison of traditional social democratic and Third Way social policy 43

2.4 Decommodification, social class and conceptualising the social democratic core constituency 46

2.5 Political system, party competition and welfare reforms 50 The impact of the electoral system for the electoral effects of the reforms 50

Competitor parties for social democracy after Third Way reforms under $P R \quad 52$

Challenge from the left 53

Challenge from the right 55 
Mainstream parties as potential challengers 59

2.6 Social democracy and declining class voting 60

Design and Methods 65

3.1 Case selection and strategy of comparison 65

3.2 Analysis of reforms 69

3.3 Analysis of the electoral consequences of reforms 72

3.4 Data sources for the statistical analysis 74

3.5 Organisation of chapters 74

4.1 The social policy of the Labour Party 78

4.2 Alignment of the social democratic core constituency in the United Kingdom 80

4.3 Welfare state reforms in Britain under New Labour, 1997-2005 81

4.4 Party competition around welfare state reforms, 1997-2005 85

4.5 Data and variables 88

4.6 Results 89

Attitudes towards Labour's policy and voting behaviour after $1997 \quad 89$

Electoral effects of Labour's policy change, 1997-2001 92

Electoral effects of Labour's policy change, 2001-05 93

4.7 Conclusion 94

5.1 The social policy of German social democracy 100

5.2 Alignment of the social democratic core constituency in Germany 101

5.3 Welfare state reforms in Germany and their political context, 1998-2009 104

5.4 Party competition on welfare state reforms in Germany, 1998-2009 110

5.5 Data and variables 113

5.6 Results 115

Attitudes towards reform proposals and actual reforms 115

First red-green cabinet, 1998-2002 118

Second red-green cabinet, 2002-05 119

The SPD in the Grand Coalition, 2005-09 121

5.7 Conclusion 123 
6.1 The social policy of social democracy in Denmark 128

6.2 The traditional core constituency of Danish social democracy 130

6.3 The labour market reforms under social democratic governments, 1993-2001 132

6.4 Party competition and welfare state reforms, 1993-2001 138

6.5 Data and variables 141

6.6 Results 142

Attitudes towards reform proposals and party choice after $1993 \quad 142$ Alignment of SD's core constituency, 1994-98 145

Alignment of SD's core constituency and breakthrough of the Danish People's Party, 1998-2001 147

6.7 Conclusion 149

\section{Sweden 153}

7.1 The Swedish social democratic party and its social policy 154

7.2 The core constituency of Swedish social democracy 157

7.3 The Third Road, crisis responses and welfare state reforms in the 1980 s and 1990 s 159

7.4 Party competition in Sweden, 1991-2006 167

7.5 Data 171

7.6 Analysis 171

Attitudes towards labour market reform proposals and party shares 171

The electoral punishment after the crisis, 1994-98 174

The SAP's recovery and the Left Party's setback, 1998-2002 176

7.7 The SAP's electoral fortunes in opposition $\quad 178$

7.8 Conclusion 179

\section{Comparative Summary 183}

8.1 General expectations and summary of findings 183

The role of the electoral system for the electoral effects of the reforms 185

The role of party competition for the electoral effects of the reforms

8.2 Discussion of rival explanations 192

\section{Discussion 201}

9.1 Applicability of arguments to other countries 202

9.2 Contribution to existing literature and political implications 204

9.3 Implications for future research on social democracy 208 


\section{Appendices 215}

Appendix A: Appendix to Chapter 4 (United Kingdom) 215

Data sources 215

Description of variables used in analysis 215

Appendix B: Appendix to Chapter 5 (Germany) 220

Data sources 220

Description of variables used in analysis 220

Appendix C: Appendix to Chapter 6 (Denmark) 226

Data sources 226

Decription of variables used in analysis 226

Appendix D: Appendix to Chapter 7 (Sweden) 232

Data sources 232

Description of variables used in analysis 232

\section{Notes 239}

\section{References 249}

Index 275 


\section{List of Tables}

Table 2.1 Social and labour market principles and policies under traditional and Third Way social democracy 4.4

Table 2.2 EGP-Class, labour market position and claim for decommodification 47

Table 2.3 Occupational composition of Western European electorates, $1995 \quad 62$

Table 3.1 Electoral system, party competition and possible contenders for reform-minded social democrats in the early 1990 s 68

Table 4.1 Party choice by selected social classes, United Kingdom 1964-1997 80

Table 4.2 Vote shares for three major parties and turnout in British general elections, 1964-2005 81

Table 4.3 Selected labour market reforms introduced by Conservative and Labour governments, 1998-2005 84

Table 4.4 OECD replacement rates of unemployment benefits for United Kingdom, 1989-2007 85

Table 4.5 Perception that Labour Party looks after interests of social groups, 1997-2005 (per cent) 90

Table 4.6 Party shares and non-voting among Labour Party's core constituency, 1992-2005 (per cent) 91

Table 4.7 Predicted probabilities of vote choice among aligned core constituency by perception of Labour, 200192

Table 4.8 Predicted probabilities of vote choice by perception of Labour, 200594

Table 5.1 Party choice by selected social classes, Germany 1969-98 102

Table 5.2 Vote shares for federal elections, Germany 1965-2009 103

Table 5.3 Classification of labour market reforms introduced by redgreen government, 1998-2005 108

Table 5.4 OECD replacement rates of unemployment benefits for Germany, 1989-2007 110 
Table 5.5 Attitudes towards labour market reform proposals by voter group, percentage points 116

Table 5.6 Party shares and non-voting among the SPD's core constituency, 1998-2009 (per cent) 117

Table 5.7 Predicted probabilities of vote choice among aligned core constituency by perception of SPD, $2002 \quad 119$

Table 5.8 Predicted probabilities of vote choice among voter groups by attitudes towards reforms, 2005120

Table 5.9 Predicted probabilities of vote choice among voter groups by attitudes towards reforms, 2005122

Table 6.1 Party shares for selected parties by selected social classes, Denmark 1973-2005 131

Table 6.2 Vote shares in Danish general elections, 1973-2007 132

Table 6.3 Classification of labour market reforms introduced by SD-led governments, 1993-2001 135

Table 6.4 Summary measures of benefit entitlements for Denmark, 1989-2002 137

Table 6.5 Attitudes towards labour market reform proposals by voter group, percentage points 143

Table 6.6 Party shares and non-voting among social democratic core constituency, Denmark 1998-2005 (per cent) 144

Table 6.7 Predicted probabilities of vote choice for attitudes towards welfare policy among aligned core constituents, 1998 (per cent) 146

Table 6.8 Predicted probabilities of vote choice for attitudes towards immigration and welfare policy among aligned core constituents (per cent) 148

Table 7.1 Party shares for selected parties by selected social classes, Sweden 1960-94 157

Table 7.2 Vote shares in Swedish general elections, 1970-2006 158

Table 7.3 Classification of labour market reforms introduced or supported by SAP, 1991-2002 164

Table 7.4 Summary measures of benefit entitlements for Sweden, 1989$2003 \quad 165$

Table 7.5 Attitudes towards labour market reform proposals by voter group, percentage points 172

Table 7.6 Party shares and non-voting among voter groups, Swedish Riksdag election 1991-2006 (per cent) 174

Table 7.7 Predicted probabilities of vote choice among voter groups by perception of SAP policy, 1998 election (per cent) 175 
Table 7.8 Voter migration in 2002 election (per cent) 177

Table 7.9 Attitudes towards lower unemployment benefits and party choice in 2002 election (per cent) 178

Table 8.1 Non-voter shares among social democratic core constituents and non-core constituents 186

Table 8.2 Summary of empirical findings 192

Table A1.1 Effects of voter group membership and perception of Labour Party on party choice in British General Election 2001. Coefficients from multinomial logistic regression models 216

Table A1.2 Effects of voter group membership and perception of Labour Party on party choice in British General Election 2005. Coefficients from multinomial logistic regression models 218

Table A2.1 Effects of voter group membership and assessment of government's performance on party choice in federal election 2002. Coefficients from multinomial logistic regression models 222

Table A2.2 Effects of voter group membership and assessment of welfare state reforms on party choice in federal election 2005. Coefficients from multinomial logistic regression models 223

Table A3.1 Effects of voter group membership and social policy attitudes on party choice in Danish General Election 1998. Coefficients from multinomial logistic regression models 228

Table A3.2 Effects of voter group membership, attitudes towards immigration and assessment of government's social policy on party choice in Danish General Election 2001. Coefficients from multinomial logistic regression models 230

Table A4.1 Effects of voter group membership and assessment of SAP policy on party choice in Swedish Riksdag Election 1998. Coefficients from multinomial logistic regression models 234

Table A4.2 Effects of voter group membership and attitudes towards lower unemployment benefits on party choice in Swedish Riksdag Election 2002. Coefficients from multinomial logistic regression models 237 



\section{List of Figures}

Figure 2.1 Role of electoral system for main electoral effects of welfare state reforms 52

Figure 3.1 Summary of party system features and hypothesised development in the four cases 75

Figure 5.1 Support for SPD among core constituency, 1998-2007 118

Figure 8.1 Electoral system, party competition and effective competitors for reform-minded social democrats, c. 1990-2009 187 



\section{List of Abbreviations}

ALG I/ALG II Arbeitslosengeld I and Arbeitslosengeld II (first- and second-tier of unemployment benefits in Germany after 2003)

\begin{tabular}{|c|c|}
\hline $\operatorname{ALMP}(\mathrm{s})$ & Active Labour Market Policy (Policies) \\
\hline AMS & $\begin{array}{l}\text { Arbetsmarknadsstyrelsen (National Labour Market Board } \\
\text { in Sweden) }\end{array}$ \\
\hline АTP & $\begin{array}{l}\text { Allmän Tillägspension/Arbejdsmarkedets Tillægspension } \\
\text { (earnings-related pension schemes in Sweden and } \\
\text { Denmark) }\end{array}$ \\
\hline BES & British General Election Studies \\
\hline BNP & $\begin{array}{l}\text { British National Party (far-right party in the United } \\
\text { Kingdom) }\end{array}$ \\
\hline C & Centerpartiet (Centre Party in Sweden) \\
\hline $\mathrm{CD}$ & $\begin{array}{l}\text { Centrumdemokraterne (Centre-Democrats, Danish } \\
\text { Centre Party) }\end{array}$ \\
\hline $\mathrm{CDA}$ & $\begin{array}{l}\text { Christen-Democratisch Appèl (Christian democratic } \\
\text { party in the Netherlands) }\end{array}$ \\
\hline $\mathrm{CDU} / \mathrm{CSU}$ & $\begin{array}{l}\text { Christlich Demokratische Union/Christlich Soziale Union } \\
\text { (Christian democratic parties in Germany) }\end{array}$ \\
\hline D66 & $\begin{array}{l}\text { Democraten '66 (Democrats 66, Dutch social liberal } \\
\text { party) }\end{array}$ \\
\hline $\mathrm{DF}$ & $\begin{array}{l}\text { Dansk Folkeparti (Danish People's Party, right-wing party } \\
\text { in Denmark) }\end{array}$ \\
\hline DNA & Det Norske Arbeiderparti (Norwegian Labour Party) \\
\hline DNWS & German National Election Studies \\
\hline DVU & $\begin{array}{l}\text { Deutsche Volksunion (German People's Union, far-right } \\
\text { party in Germany) }\end{array}$ \\
\hline EGP scheme & $\begin{array}{l}\text { Class Scheme developed by Erikson, Goldthorpe and } \\
\text { Portocarero }\end{array}$ \\
\hline EL & $\begin{array}{l}\text { Enhedslisten (the Red-Green Alliance, far-left party in } \\
\text { Denmark) }\end{array}$ \\
\hline
\end{tabular}




\begin{tabular}{|c|c|}
\hline FDP & $\begin{array}{l}\text { Freie Demokratische Partei (Free Democratic Party, } \\
\text { liberal party in Germany) }\end{array}$ \\
\hline FP & $\begin{array}{l}\text { Folkpartiet Liberalerna (The Liberal People's Party, liberal } \\
\text { party in Sweden) }\end{array}$ \\
\hline FPÖ & $\begin{array}{l}\text { Freiheitliche Partei Österreichs (Freedom Party of } \\
\text { Austria, right-wing party in Austria) }\end{array}$ \\
\hline FPTP & $\begin{array}{l}\text { First-Past-The-Post Electoral System (electoral system in } \\
\text { the United Kingdom) }\end{array}$ \\
\hline FrP & $\begin{array}{l}\text { Fremskridtspartiet (Progress Party, populist right-wing } \\
\text { party in Denmark) }\end{array}$ \\
\hline GLES & German Longitudinal Election Studies \\
\hline JSA & $\begin{array}{l}\text { Job Seekers Allowance (unemployment benefits in the } \\
\text { United Kingdom after 1996) }\end{array}$ \\
\hline $\mathrm{KD} / \mathrm{KDS}$ & $\begin{array}{l}\text { Kristdemokraterna/Kristdemokratiska Samhällspartiet } \\
\text { (Swedish Christian democratic party, formerly labelled } \\
\text { Christian Democratic Unity) }\end{array}$ \\
\hline $\mathrm{KF}$ & $\begin{array}{l}\text { Det Konservative Folkeparti (Conservative People's Party } \\
\text { in Denmark) }\end{array}$ \\
\hline $\mathrm{KrF} / \mathrm{KD}$ & $\begin{array}{l}\text { Kristeligt Folkeparti (Christian People's Party, Christian } \\
\text { democratic party in Denmark, also used the label KD) }\end{array}$ \\
\hline LibDems & $\begin{array}{l}\text { Liberal Democrats (social liberal party in the United } \\
\text { Kingdom) }\end{array}$ \\
\hline M & $\begin{array}{l}\text { Moderaterna (The Moderate Party, conservative party in } \\
\text { Sweden) }\end{array}$ \\
\hline MMP & Mixed Member Proportionality Electoral System \\
\hline MP & $\begin{array}{l}\text { Miljöpartiet de Gröna (The Environmental Party of the } \\
\text { Greens, green party in Sweden) }\end{array}$ \\
\hline ND & $\begin{array}{l}\text { Ny Demokrati (New Democracy, populist right-wing } \\
\text { party in Sweden during the 199os) }\end{array}$ \\
\hline NHS & National Health Service in the United Kingdom \\
\hline NPD & $\begin{array}{l}\text { Nationaldemokratische Partei Deutschlands (National } \\
\text { Democratic Party of Germany, far-right party in } \\
\text { Germany) }\end{array}$ \\
\hline OECD & $\begin{array}{l}\text { Organisation for Economic Co-operation and } \\
\text { Development }\end{array}$ \\
\hline ÖvP & $\begin{array}{l}\text { Österreichische Volkspartei (Austrian People's Party, } \\
\text { Christian democratic party in Austria) }\end{array}$ \\
\hline PDS & $\begin{array}{l}\text { Partei des Demokratischen Sozialismus (Party of } \\
\text { Democratic Socialism, left-wing and post-communist } \\
\text { party in Germany) }\end{array}$ \\
\hline
\end{tabular}


PR

$\operatorname{PvdA}$

RNM

RV

SAP

SD

SD

SDP

SERPS

SF

SNP

SP

SPD

UKIP

Venstre VVD

$\mathrm{VP} / \mathrm{VPK}$

WASG
Proportional Representation Electoral System(s)

Partij van de Arbeid (Dutch Labour Party)

Routine Non-manual Employees

Det Radikale Venstre (Danish social liberal party)

Sveriges Socialdemokratiska Arbetareparti

(Swedish social democratic party)

Socialdemokratiet i Danmark (Danish social democratic party)

(in Sweden chapter) Sverigedemokraterna (Sweden

Democrats, populist right-wing party in Sweden)

Social Democratic Party (social democratic party and one predecessor of Liberal Democrats in the United Kingdom) State Earnings-Related Pension Scheme (abolished earnings-related pension scheme in the United Kingdom)

Socialistisk Folkeparti (Socialist People's Party, left socialist party in Denmark)

Scottish National Party (regionalist party in the United Kingdom)

Socialistische Partij (Socialist Party, Dutch left socialist party)

Sozialdemokratische Partei Deutschlands (German social democratic party)

United Kingdom Independence Party (populist right-wing party in the United Kingdom)

Danish Liberal Party

Volkspartij voor Vrijheid en Demokratie (People's Party for Freedom and Democracy, Dutch conservative-liberal party)

Vänsterpartiet/Vänsterpartiet Kommunisterna (Left

Party in Sweden, formerly labelled Left Party - The

Communists)

Wahlalternative Arbeit und Soziale Gerechtigkeit (Labour and Social Justice - The Electoral Alternative, German left-socialist association and party, merged with PDS into the Left Party) 



\section{Preface}

This book project began more than five years ago when I handed in my diploma thesis, in which I had found a remarkable break in class voting in unified Germany after the social democratic party engaged in pathbreaking welfare state reform in the electoral term 2002-05. The idea that welfare state reforms may lead to realigning elections came to my mind after considering recent electoral change in other European countries. My then supervisor, Alexander Gattig, suggested that I turn this idea into a $\mathrm{PhD}$ project. The Department of Political Science at Aarhus University gave me the opportunity to conduct this project in a stimulating intellectual environment and, later, to turn the PhD thesis into a book. On the journey to complete the research project, I have benefited from the help and good advice of a number of people, and I would like to express my gratitude to them.

First, I owe thanks to my main supervisor, Christoffer Green-Pedersen, and my co-supervisor, Rune Stubager, for their excellent advice, constructive criticism and support when I was writing my thesis. They also helped me integrate into a new academic environment in Denmark and to steer my PhD project at various stages. I also owe special thanks to Herbert Kitschelt, who was my supervisor during my stay as a visiting scholar at the Department of Political Science, Duke University, during the fall semester 2009. He offered many inspiring and stimulating comments and also shaped my research interests beyond the thesis and the later book.

Second, I have to thank my two office mates, Flemming Juul Christiansen and Christian Hjerrild Ovesen, for creating a good and enjoyable daily work atmosphere, and for countless discussions on the project, politics and all kinds of other issues beyond politics.

Further thanks go to the members of the Research Section on Danish Politics and the Comparative Politics Section, of which I am a proud member. They provided me with excellent and inspiring comments and constructive criticism during the various presentations of my research 
project. The same goes for the group of $\mathrm{PhD}$ scholars at the department who provided an intellectually stimulating and 'hyggelig' working environment and helped me with the various practical and linguistic aspects of getting settled in a new country. I also owe thanks to various members of staff at the department. Anne-Grethe Gammelgaard, Birgit Kanstrup, Inge Rasmussen and Tina Aronro were always very keen to help me with administrative and practical issues and the organisation of teaching. I thank Vivi Mikkelsen, Berit Møller and Stig Petersen from the department's IT support services for their technical assistance at various points. I also thank Annette Andersen for her dedicated secretarial assistance and language editing for both the thesis and the later book.

Special thanks go to those persons who sharpened my thinking at various stages of the project by discussing, commenting on and criticising various aspects of my research, as well as expressing their enthusiasm for the project in general. In particular, these are Carsten Jensen, Flemming Juul Christiansen, Florian Langbehn, Jens Peter Frølund Thomsen and Rune Slothuus, who often 'expanded' their working week by attending the Friday Bar with me to discuss all kinds of issues concerning political science research and beyond. I also have to thank a lot of people outside the department who shared their comments when I presented various parts of the project at conferences, seminars, summer schools and workshops. This concerns the lecturers and participants at the PhD Summer School Course 'The Political Opportunities and Constraints in Welfare State Reform' in Oslo, August 2009; the PhD Seminar 'Social Research as a Craft', in Aarhus and Odense, February-April 2009; the 'NordWel and REASSESS International Summer School 2010: State, Society \& Citizen', University of Southern Denmark, 15-20 August 2010; the conference participants at the 'Elections, Public Opinion and Parties Annual Conference', EPOP 2010, University of Essex, 10-12 September 2010; the annual meeting of the Danish Political Science Association 2010, Vejle Fjord, 4-5 November 2010; and the workshop 'Political Parties and Welfare State Reform', Department of Political Science, Aarhus University, 18 January 2011. I also thank Klaus Armingeon, Oddbjørn Knutsen and Kees van Kersbergen as members of the dissertation committee, and Herman van de Werfhorst and the editorial board from Amsterdam University Press for their interest and the critical and constructive comments on my thesis that helped me to turn it into a book.

I also owe special thanks to Kees van Kersbergen for encouraging me to turn the $\mathrm{PhD}$ thesis into a book and for the valuable comments on a revised version that transformed the dissertation into a real book. 
None of the persons mentioned above are, of course, to be held responsible for interpretations, omissions or mistakes of any kind in this book.

Aarhus, Oktober 2012

Christoph Arndt 



\section{Introduction}

\subsection{Empirical puzzle}

In recent decades, policymakers in all advanced Western nations have implemented encompassing welfare state reforms, breaking with past welfare arrangements. Social democracy, in particular, engaged in significant policy change under the Third Way paradigm (Giddens 1998; Cuperus et al. 2001; Green-Pedersen et al. 2001; Clasen 2002; Bonoli \& Powell 2004; Merkel et al. 2008; Huo 2009; Randall \& Sloam 2009; Keman 2011). The transformation and modernisation of social democracy under Third Way agendas was a successful strategy in the early and mid-1990s, as many social democratic parties regained power after often long periods in opposition (Cuperus \& Kandel 1998; Powell 2004). The Third Way was an explicit appeal to new voters from the centre ground, using well-known labels such as New Labour in Britain or 'die Neue Mitte' (the New Centre) in the case of the German social democratic party (SPD). In office, the new agenda became visible as Third Way social democracy introduced welfare state reforms that broke with social democracy's traditional reputation on welfare, with which ties with its core constituency in the 2oth century had been forged (Esping-Andersen 1985, 1990; Bonoli \& Powell 2004; Merkel et al. 2008; Huo 2009). ${ }^{1}$

However, in many Western countries, social democratic parties suffered a remarkable electoral decline after the turn of the millennium. Parliamentary elections in countries such as Denmark, Germany, the Netherlands and the United Kingdom resulted in disastrous losses for the incumbent social democratic parties that had gained office under the Third Way agenda. The 2009 European Parliament elections showed similar tendencies at the supra-national level. The losses were typically concentrated among social democracy's core constituency of manual workers and lower white-collar employees, indicating that these parties will continue to suffer a weakened position in the near future. In contrast, many parties on the left and right wings of the party spectrum 
increased their electoral strength or even emerged as new competitors. In a postscript to a volume on the Third Way (Bonoli \& Powell 2004), Bonoli (2004: 21of) compares party shares from the early 2000 s with corresponding figures from the 1990 os and characterises the Third Way as an electoral failure.

This book provides a comparative study of the electoral consequences of Third Way welfare state reforms. It investigates whether Third Way reforms alienated traditional social democratic core constituents and sheds some light on the factors causing variation between countries. The book's main argument is that Third Way reforms indeed produced an electoral setback for social democrats, and that the nature of the setback is contingent on the electoral system and the party competition social democrats face when reforming the welfare state.

The interplay between social policy reforms and social democracy's performance at the ballot box has been largely neglected in the literature, even though the importance of the welfare state for social democracy's electoral fortunes was emphasised from very early on (for a review, see e.g. Castles 1978; Korpi 1983; Esping-Andersen 1985, 1990; Therborn 1987; Keman 1988, 1993). Only recently have scholars begun to examine the electoral consequences of welfare state reforms (Armingeon \& Giger 2008; Giger 2011; Giger \& Nelson 2011; see also Karreth et al. 2012 for the electoral effects of social democracy's move to the centre). However, these contributions remain at the macro-level, since only party shares or vote choice for the incumbent have been used as the dependent variable, rather than the party choices of individual voters. This book adds analysis at the micro-level by using election studies and survey data to study the electoral effects of welfare state reforms implemented under social democratic governments in four West European countries.

Analysing the electoral consequences of Third Way welfare state reforms from a comparative perspective, this study speaks to both the welfare state literature and political sociology. Welfare state research is voluminous and, in recent decades, has often focused on the political constraints and opportunities that shape and condition the prospects of retrenchment and welfare state reform. Political sociology debates typically concern whether class voting has declined as a general political phenomenon in modern Western societies.

Paul Pierson's seminal 'New Politics of the Welfare State' approach $(1994,1996,2001)$ states that the logic of welfare state reform diverges from the logic of welfare state expansion as policymakers can only claim credit for the latter. The reason is that the welfare state has formed its 
own constituency and, consequently, policymakers interested in re-election refrain from making encompassing reforms. Accordingly, in Pierson's perspective, the electoral threat accounts for the resilience of the welfare state, but the actual consequences of the reforms have not been thoroughly analysed. This book analyses how the electoral threat materialises after policymakers have reformed the welfare state. In particular, it reveals the extent and context-specific nature of the electoral hazard social democrats face if they reform the welfare state in ways that conflict with the attitudes of its own welfare-minded constituency.

This is in contrast to Fiona Ross (2000), who claims that a 'Nixon-goesto-China logic' is at work, as social democratic parties can reform the welfare state without being seriously punished by the electorate. Unlike market-liberal and conservative opponents, these parties are regarded as defenders of the welfare state who undertake reform out of necessity and not due to ideological motivations (see Klitgaard 2007 for a similar argument). Therefore, given their ownership of welfare issues, social democrats are expected to evade serious electoral consequences after having reformed and retrenched the welfare state. This book demonstrates that this is not true; Ross's claim about issue ownership is rather static and does not account for the loss of the welfare issue as a result of reforms that break with social democracy's traditional social policy image. If this happens, and other parties win the issue, the electoral setback occurs against a Nixon-goes-to-China logic.

Turning to recent debates in political sociology, my contribution is twofold. Beginning with the heated controversy over whether class voting or, more generally, cleavage-based voting declined in the late 20 th century, scholars of party competition and electoral behaviour increasingly focused on changing patterns of party competition and de-/realignments of major parties' core electorates. Class voting was said to decline as social structures change, indicating that the working-class vote was becoming less important for political competition (e.g. Przeworski 1980; Przeworski \& Sprague 1986; Kitschelt 1994, 1999). Moreover, the rising share of people with higher education and thus cognitive skills would reduce the importance of social structural attributes such as class or religion for voting behaviour (e.g. Franklin 1985; Dalton 1996). One weakness of this literature is that it neglects the role of the welfare state and social policy for voting behaviour, whereas societal change is the predominant explanation for changing patterns of voting behaviour.

In contrast to the structural reasoning in large parts of the class voting literature, the present study offers a more concrete policy explanation for 
the suspected decline of class voting. If class-based parties such as social democrats engage in policies against the political preferences of classes traditionally affiliated with the party, patterns of class voting may change. The question of whether social democrats have sacrificed their core constituency in the Third Way reforms is an important one. A stable core constituency is typically the backbone of political parties that secures them a certain level of electoral support, regardless of whether the party is in government or not, has decent leadership or not, and so on. If these voters dealign, parties find themselves in a weakened electoral position, as the guaranteed support from the core constituency has waned substantially. This can, of course, be compensated politically if social democracy wins new coalition options and is strategically more flexible in terms of office-seeking (Kitschelt 1994, 1999; Häusermann 2006, 2010). In this respect, this book offers a policy explanation to the debate on whether class voting has declined or changed.

Similarly, by examining the prospects of the realignment of social democratic core voters with new populist left and authoritarian right-wing parties, this book speaks to the literature on dealignment and realignment. Since the 1970s, political sociology has studied the rise and establishment of new radical right parties (see Kitschelt 2007 for a comprehensive review). One consistent major empirical finding has been that these parties enjoy strong backing among the working class. Moreover, Kriesi et al. (2008) argue that right-wing parties have played an important role in the transformation of West European party systems as a consequence of globalisation, as they absorb the 'losers of globalisation'. The literature typically focuses on socio-cultural issues, in particular immigration, to explain the rise and breakthrough of this party family. This study proposes that the welfare state and social policy can also be important determinants for the electoral breakthrough of such parties. Another recent development is the rise and consolidation of left-wing populist parties in countries such as Germany and the Netherlands. The present book reveals how the Third Way has driven the emergence of this type of party in some countries, and examines whether the Third Way can be seen as a favourable context for the rise and establishment of parties on the far left and the far right. As the Third Way loosens the ties between social democracy and its traditional core constituency, these parties may have a chance to foster a realignment of these voters. I will now briefly outline the main arguments. 


\subsection{The arguments in brief}

In a comparative study on the social democratic Third Way, Huo (2009) theorises the ideological background of social democracy, the change to the Third Way paradigm and the institutional factors accounting for country-specific differences in policy outcomes. Specifically, Huo (2009: 1off) argues that the paradigm shift implies an electoral trade-off for social democracy, as the party may appeal to other voters than the core constituency, which is in turn alienated by the reform agenda. This is because Third Way reforms do not represent the social policy preferences of social democracy's core constituency, namely working-class voters. Against this backdrop, several social democratic parties experienced declining electoral support after they engaged in significant policy change under the Third Way.

However, what is lacking in the literature is a framework that theorises the decline of social democracy as a consequence of the Third Way and its contextual conditions. Such a framework would allow a comparative empirical analysis of the electoral consequences of Third Way reforms.

To theorise the role of the welfare state and social policy for the alignment of social democracy's core constituency, this study reintroduces Esping-Andersen's classic work $(1985,1990)$ on the importance of social policy for the electoral fortunes of social democracy. In this perspective, the welfare state is crucial for the long-term mobilisation of the social democratic core constituency: the working class and lower white-collar employees. These voters demand decommodification of labour in their own interest, and social democrats represent their natural political ally by advocating a decommodifying welfare state. This leads to the alignment between social democracy and the working class and lower whitecollar employees. Given the book's focus on the electoral consequences of social democratic welfare reforms, Esping-Andersen's theory also provides a story about social policy's feedback effects. Social democracy risks a dealignment of its core constituency if it engages in policies that go against the preferences of its core constituency. Core constituents may dealign from social democracy or even realign with other parties if the decommodification tie is broken by social democratic policy.

Since Third Way reforms have been seen as recommodification of labour (e.g. Dingeldey 2007; Merkel et al. 2008; Huo 2009), we should expect social democracy to lose considerable electoral support, especially among core constituents alienated by the reforms. Therefore, the basic argument is that welfare state reforms implemented under Third Way agen- 
das have caused a lasting electoral setback for social democracy among its traditional core constituency.

Moreover, I claim that the extent and nature of the electoral backlash that follows the reforms is contingent on the electoral system under which social democrats reform the welfare state, and which type of challengers they face. This claim rests upon arguments from the New Politics and retrenchment literature, which originally regarded institutions and party competition as crucial determinants for the process of welfare state reform. Institutions and features of political systems structure the political constraints and opportunities policymakers face when they want to reform and recalibrate mature Western welfare states (e.g. Pierson 1994, 1996; Kitschelt 2001a; Green-Pedersen 2002a; Korpi \& Palme 2003; Allen \& Scruggs 2004; Starke 2008). This book will apply and refine the respective arguments from the literature to theorise the contextual conditions for the actual electoral consequences of Third Way welfare state reforms.

In a nutshell, I argue that a majoritarian electoral system effectively prevents reform-minded mainstream parties, in this case social democrats, from being challenged by parties on the margins or protest parties that may emerge as consequence of the reforms (Kitschelt 2001a; Starke 2008). Under majoritarian voting systems, social democrats should experience a dealignment of their dissatisfied core voters, as these voters stay home given the lack of competitive, credible, and efficient alternatives. For instance, Britain's first-past-the-post (FPTP) system may explain why New Labour was not challenged by parties on the margins after it abandoned its traditional working class programme. Hence, I claim that a majoritarian electoral system leads to lower turnout among the social democratic core constituency as a consequence of dissatisfaction with ideological realignment and Third Way welfare reforms.

By contrast, proportional representation (PR) electoral systems do not prevent social democrats from being challenged by competitor parties. Rather, the welfare state reforms may not only lead to dealignment, but may also realign the core constituency with other parties. Serious challengers can exploit the window of opportunity opened by Third Way reforms and forge a realignment of social democratic core constituents.

I maintain that leftist parties represent one type of serious challenger, as they are typically pro-welfare and advocate a generous welfare state that reflects the social policy preferences of social democracy's core constituency (Esping-Andersen 1985; Kitschelt 1999, 2001a; Arter 2002, 2003; March \& Mudde 2005). Parties of the new right represent a second type of dangerous challenger, as their stance on socio-cultural issues is close 
to the attitudes of social democracy's core constituency (Lipset 1981; Kitschelt 2001b; Scheuregger \& Spier 2007; Houtman et al. 2008; van der Waal et al. 2010). Moreover, if these parties appear welfare-minded, they particularly target social democratic core voters by representing social protectionist attitudes. These aspects come to the fore after social democratic parties have broken their ties with the core constituency (Kitschelt 2003, 2004). I claim that an authoritarian right-wing party can exploit the Third Way electorally by realigning with social democracy's traditional core constituency.

This book offers insights on how the Third Way has constituted a favourable political context for the gains of a new populist left and the breakthrough and establishment of parties on the far right. Another electoral effect can be gains for established mainstream parties, such as Christian democrats. Mainstream contenders may exploit the political space opened by Third Way social democracy by positioning themselves closer to the political preferences of the social democratic core constituency during the reform period.

However, these proposed effects of the reforms do not occur automatically, as the prospects of realignment are contingent on voters' credibility considerations. Challengers damage their credibility if they endorse a reform agenda or previously participated in reforms in a legislative or formal coalition. My claim is that challenger parties that have been involved in reforms or plan to become so in the future spoil their chances of forging realignments with social democratic core constituents.

My arguments offer some useful explanations for why Third Way reforms may have different electoral consequences under different conditions and circumstances. The absence or presence of particular competitor parties and their actual credibility do affect the nature of the electoral backlash faced by Third Way social democrats after reforming mature Western welfare states.

\subsection{Structure of the book}

Chapter 2 elaborates the theoretical framework for the study of the electoral consequences of Third Way reforms. The chapter conceptualises the role played by social policy and the welfare state in the ties that were formed between social democracy and its core constituency during the second half of the 2oth century. I discuss how the core constituency risks being alienated from social democracy in a lasting manner as a conse- 
quence of Third Way reforms that contradict these voters' social policy preferences. Next, I discuss the electoral system and competitor parties that condition the electoral consequences of Third Way reforms and thus account for cross-country variations.

Chapter 3 describes the design and methodology, case selection and strategy of comparison, the approach to analysing the reforms and their electoral consequences, and lists the data sources.

Chapter 4 analyses the electoral consequences of Third Way reforms under the majoritarian FPTP electoral system in the United Kingdom. The chapter demonstrates that FPTP systems lead to a dealignment of social democratic core constituents. The ideological transformation of British social democracy in the form of New Labour and the welfare state reforms under the New Deal led to lower turnout among former core Labour supporters after 1997. In addition, the Liberal Democrats captured some former Labour voters who were dissatisfied with the new policies adopted by their old party.

Chapter 5 shows how dangerous a pro-welfare and populist left-wing challenger can be for Third Way social democracy. The chapter analyses the setback suffered by the German SPD after engaging in serious policy change after 1998, when the party implemented path-breaking welfare state reforms under Agenda 2010. Afterwards, the SPD was challenged by the Left Party as a competitor on welfare grounds. The results reveal that the SPD lost reform-averse core constituents, who realigned with the socialist challenger. Abstention is another reason for social democratic decline in Germany as a consequence of Third Way reforms.

Chapter 6 demonstrates that an authoritarian right-wing challenger can be extremely dangerous, as it exploits the favourable context created by social democracy's adoption of a Third Way agenda. After the Danish social democrats (SD) introduced three rounds of labour market reforms, they lost a considerable part of their core constituency, which realigned with the rightist Danish People's Party in 2001. The People's Party has now retained these voters for almost a decade. Chapter 6 tests and confirms the arguments that contenders need to be credible to mobilise social democratic core voters. The results show that by supporting the SD during the reform period, the Socialist People's Party damaged its potential to benefit from the reforms. In addition, the Danish case reveals that a mainstream party can benefit from Third Way reforms. Having modernised its own programme, the liberal party Venstre gained a foothold among the traditional voter base of Danish social democracy during the reform period. 
Chapter 7 analyses the electoral effects of Swedish social democracy's social policy in the period between 1991 and 2006. Sweden serves as a sort of control case, given that the social democratic party (SAP) did not abandon its traditional stance on welfare and only introduced moderate reforms, many of which were temporary, as they were reactions to an economic crisis rather than part of a distinct Third Way agenda (Merkel et al. 2008: chap. 8). The results show that the SAP did not suffer lasting a dealignment or even a realignment, as it recaptured votes that it had lost in the 1998 election, four years later. This confirms the expectation that social democrats do not lose their core constituency per se, as long as they are able to stick to a more traditional social policy.

Chapter 8 offers a comparative perspective, summing up the findings from the four case studies in light of the theoretical arguments. Alternative explanations are discussed and contrasted with the empirical findings.

Chapter 9 concludes and discusses the theoretical framework and the study's empirical findings, situating them in the existing literature and recent political developments. It discusses the political implications of the results and their generalisability to other cases where social democratic parties have reformed the welfare state and broken with their traditional social policy. 



\section{Theoretical Background}

This chapter develops the theoretical framework for the analysis of the electoral consequences of Third Way welfare state reforms. It begins with an outline of social democracy's transformation under the Third Way, and the background to this transformation. Then, it theorises the role of social policy in the formation of the social democratic core constituency's partisan alignment; delineates the potential dealignment that is risked by social democracy if it engages in policy change that goes against the core constituency's political preferences; and conceptualises the social democratic core constituency in terms of a class framework. It continues with a discussion of the effect of electoral systems and the role of particular competitor parties for the electoral fortunes of Third Way social democrats. The chapter concludes with a discussion on the suspected decline of class voting as the most obvious rival to the explanation presented in this book.

\subsection{The political-economic and societal background to Third Way policies}

Against a background of poor election results and a wave of centreright governments in the Western world in the 1980s, a time when social democrats were out of office for long periods in countries such as Denmark, Germany, the Netherlands, Portugal, the United Kingdom and the United States, social democracy had to reconcile its electoral appeal with changed circumstances (Kitschelt 1994; Giddens 1998; Cuperus et al. 2001). The economic and demographic changes that had been occurring since the 1970 os forced social democratic parties to transform their electoral programmes and to develop new electoral winning formulas (Przeworski 1985; Kitschelt 1994, 1999; Pontusson 1995). If they failed to do so, social democracy's future vote- and office-winning chances were thought to be slim. 
As for the economic challenges for social democracy, the two oil crises in 1973 and 1981-82, high inflation rates and the emergence of structural unemployment stripped social democrats of their traditional Keynesian macro-economic toolkit and left the provision of largely passive social security benefits no longer practicable (Pontusson 1995; Huber \& Stephens 1998; Huo 2009; Lindvall 2010). Given the accumulated public debts often in combination with high inflation - deficit spending and demand management had ceased to be feasible options for social democratic governments by the $1980 \mathrm{os}$, and this became even more pronounced after the fall of the Iron Curtain and intensifying globalisation (e.g. Pontusson 1995; Huber \& Stephens 1998; Notermans 2006; cf. Merkel et al. 2006, 2008 for reviews of the literature). These changed macro-economic conditions put pressure on the social security provisions that social democracy had traditionally advocated.

The unemployment problem that emerged following the first oil crisis in 1973 constituted another challenge for social democracy, since its traditional social and labour market policies were no longer part of the solution, but rather part of the problem. Encompassing social security schemes that provided passive and generous transfer incomes in case of unemployment or sickness were designed for temporary redundancies and frictional unemployment, but led to problems of social exclusion and long-term unemployment after the Golden Age of the welfare state (Huo 2009). Facing budgetary constraints and mass unemployment, social democracy was confronted with the problem of how to reform and defend the welfare state at a time when its old policy instruments had become ineffective (e.g. $\mathrm{Hu}$ ber \& Stephens 1998; Merkel et al. 2006, 2008; Huo 2009; Lindvall 2010).

At the societal level, social-structural change has constituted another political challenge for social democracy in recent decades. First, changes in the employment structure of Western societies have led to a decline in the number of manual workers, the traditional electoral backbone of social democratic parties. The same goes for the declining union membership in many (but not all) Western countries. These trends will automatically lead to a weaker electoral and political position for social democratic parties, unless this is offset by winning new groups of voters and by shaping new electoral coalitions (e.g. Przeworski 1985; Przeworski \& Sprague 1986; Kitschelt 1994, 1999).

A second, related aspect is the rise of the service sector professions and the growing electoral importance of the salaried middle class (Kitschelt 1994; Van de Werfhorst \& de Graaf 2004; Oesch 2006). Although not traditionally inclined to vote for social democratic parties, these voter seg- 
ments are considered to be new target constituencies for social democracy in post-industrial societies that ought to be wooed by new electoral policies. However, the changed electoral appeal of social democratic parties towards more market-oriented policies on the one side, and more liberal socio-cultural policies on the other, constitutes an electoral dilemma in itself, since the working class may be scared off by the changed electoral agenda (Kitschelt 1994, 2001b).

A third factor that has been discussed in the literature is demographic change. As Western societies age and life expectancy rises, the fiscal burden for Western welfare states is increasing (OECD 2000). Accordingly, the changing ratio between working-aged citizens and the elderly requires a re-allocation of public revenues and thus a re-balancing of welfare provisions to account for ageing societies. However, this has implications for the future strategies of social democratic parties, although these are less straightforward than the other economic and societal trends mentioned above (cf. Merkel et al. 2006, 2008).

To cope electorally with these challenges, it was argued that social democracy ought to engage in programmatic and strategic realignment, especially because the working-class core constituency is shrinking and the electorate is becoming more heterogeneous. This argument was made most prominently in Kitschelt's seminal book (1994) and Giddens' writings $(1998,2000)$. These works spelled out several general strategies for the future political success of social democratic parties that take account of economic and social change in post-industrial societies. First, on the socio-cultural dimension, social democratic parties ought to shift their policies towards more libertarian positions in order to attract the rising share of salaried middle-class voters. Second, increasing international competition and further processes of economic change call for a moderation of social democracy's positions on the socio-economic dimension in order to remain electable for broader segments of the electorate. This may also come at the expense of a clear distinction between social democracy and mainstream bourgeois parties with regard to this dimension of political competition.

\section{Social Democracy's transformation towards the Third Way}

The above-mentioned arguments for the transformation of social democracy found their distinct expression in the early 1990 os and afterwards, when many social democratic parties adapted a Third Way agenda to reach out to new constituencies (Cuperus et al. 2001; Green-Pedersen et 
al. 2001; Bonoli \& Powell 2004; Merkel et al. 2008; Huo 2009; Keman 2011). The Third Way has typically been used as a catchphrase to characterise the modernisation of social democracy, inspired by Gidden's writings $(1998,2000)$. The term will be used to subsume the transformation of social democratic parties after the 1980 os, albeit the fact that not every party explicitly referred to this term, while others modernised with a similar change of policy before the catchphrase became ubiquitous (cf. Green-Pedersen et al. 2001).

Under the Third Way, social democracy indeed moderated its policies in many areas (Green-Pedersen et al. 2001; Bonoli \& Powell 2004; Merkel et al. 2008; Huo 2009; Randall \& Sloam 2009). In economic, fiscal and social policy, many old policy instruments were given up and replaced by policy instruments that are typically assigned to centre-right parties (GreenPedersen et al. 2001; Green-Pedersen \& van Kersbergen 2002; Merkel et al. 2008). Thus, in line with Kitschelt's claims, social democracy abandoned many of its distinct traditional leftist positions and became less egalitarian, focusing more on equality of opportunity than of outcome.

Third Way social security reforms aimed to replace the 'welfare without work' principle with the 'welfare to work' principle (Green-Pedersen et al. 2001). This reconstruction of the welfare state marked a departure from the decommodification principle, as incomes could no longer be realised outside the market for longer periods, as originally claimed by EspingAndersen $(1985,1990)$. Rather, the reforms were intended to enforce labour market participation. Old social democracy had explicitly seen the function of social security as providing a source of non-market income that allowed a sufficient standard of living, to be ensured by relatively unconditional and unlimited access to generous and universal social security benefits.

Labour market participation would be promoted by improving the employability of benefit claimants. Third Way reforms placed much more emphasis on Active Labour Market Policy (ALMP) and enabling policies. On the one hand, job placement services and training programmes for the unemployed were improved and expanded. On the other hand, the reforms introduced coercive elements, as passive behaviour was sanctioned. In combination with the increased conditionality, this policy change goes against Esping-Andersen's notion (1990: 21ff, $47 \mathrm{ff}$ ) that decommodification is appropriately secured by rather unconditional access to benefits regardless of the claimants' behaviour, actual performance or labour market attachment. Taking part in activation is no longer a right, but a duty (e.g. Green-Pedersen et al. 2001: 316). In this respect, Third Way reforms replaced welfare with workfare and security with flexicurity. 
On a more philosophical level, Huo (2009: chap. 2) has conceptualised the Third Way as a departure from two traditional social democratic principles: egalitarianism and solidarity. The Third Way transformed these principles into prioritarian egalitarianism and productivist solidarity. Old social democracy's notion of egalitarianism was to improve the core constituency's standard of living by redistribution and social security schemes, on the grounds that the working class was typically the worstoff labour market group in industrial society. This was secured by wage compression and wage replacement if a worker was not able to derive his income from the market. Thus, egalitarianism incorporated the decommodification principle (Huo 2009: 13). Old social democracy's notion of solidarity was targeted at the rather homogenous working class, even though it also showed solidarity with the poor. The notion relied on the instrument of the social security system with passive benefits, but without an emphasis on work (Huo 2009: 20).

Prioritarian egalitarianism and productivist solidarity, by contrast, take into account the unemployment problem that emerged in the $1970 \mathrm{OS}$ and, more generally, the changing economic and social structures. The Third Way is seen as a response to these developments, since it incorporates a more heterogenic electorate into social democracy's appeal and strategies (Giddens 1998: 2off; Kitschelt 1999; Huo 2009: chap. 2) - but not without costs. Social democracy is facing a dilemma, since the two new principles do not make the core constituency the focal group of social policy, but instead emphasise new social risk groups and other marginalised social groups outside social democracy's traditional core constituency (Huo 2009: 11, 21ff, 315f). In terms of policy, this means a shift from social protection through decommodification and wage compression to enabling policies and poverty reduction (Huo 2009: 18).

To understand the difference between traditional social democracy and Third Way social democracy, the next section delineates EspingAndersen's arguments on the importance of the welfare state for social democratic voter alignment.

\subsection{Social policy and the welfare state as a base for social democratic alignment}

Esping-Andersen $(1985,1990,1999)$ conceptualised the welfare state as an agency to tie and mobilise the social democratic core constituency. As social democracy advocates an encompassing and generous welfare state, 
it attracts a particular social group, the working class, because the welfare state has a risk-hedging function and thus decommodifies individuals from pure market dependency. In turn, the manual classes argue for decommodification due to their limited resources, which leave them in a precarious position in the labour market and with low living standards if they are exposed to pure market forces. Furthermore, decommodification works as one element of egalitarianism, a key theme for social democracy, and improves the living conditions of the working class and other less well-off segments (Esping-Andersen 1985; Huo 2009: chap. 2). Thus, social democracy formed an alignment with the manual classes by offering the politics of decommodification and the welfare state as agency. This was expanded to include lower white-collar employees who held similar positions in the labour market and who were demanding risk-hedging policies (Esping-Andersen 1985).

To account for the social democratic mobilisation by using decommodifying welfare policies and the welfare state, we have to draw on voter preferences and interests; that is, to look at the individual level. This allows us to establish a theoretical link between the partisan alignment of particular voter groups and social democracy and to explain partisan dealignment due to welfare state reforms, which is discussed later.

The basic claim here is that traditionally, social democrats have successfully mobilised the manual classes via the politics of decommodification because those voters should have a particular individual interest in the decommodification of labour given their position in the labour market. Pure exposure to market forces would create particular hardship for these individuals, as labour is only a discrete commodity depending on labour demand and the price of labour (Esping-Andersen 1985: 31). Labour as a commodity is therefore the most conflictual issue in social policy (Esping-Andersen 1990: 35). Moreover, the risk of unemployment is contingent on the economic context and an individual's human capital.

A related feature is the effect of commodification on individual living standards. Given commodified labour, an individual's living standard is contingent on his or her skills and the demand for these skills. As the manual classes have limited skills that are abundant on the labour market, the logic of pure competition on manual labour is likely to decrease wages and thus living standards. Moreover, a low skill level implies limited chances of individual promotion. Collective action and institutionalised wage bargaining by trade unions should therefore be in the interest of manual workers since this, unlike the predominantly market allocation of manual labour, will improve their living standards (Esping-Andersen 
1985: 31ff; Weakliem \& Heath 1994: 244ff; Korpi 2006). Moreover, as manual workers are expected to have below-average incomes, they also have an interest in income redistribution, wage compression and generous welfare entitlements that will increase their living standards by decommodifying labour. Based on these arguments, Esping-Andersen (1990: 22) claimed that decommodification has always been a priority for labour.

Decommodification in favour of the working class is understood as the establishment of generous and unconditional income maintenance in case of unemployment or sickness. If this is fulfilled, the living standards and economic fortunes of the working class are no longer purely contingent on market forces, but can be improved independent of market forces (Esping-Andersen 1990: 37; cf. Huo et al. 2008). Decommodification is institutionalised by a universal welfare state and legislation guaranteeing generous and unconditional benefits, accompanied by high income replacement rates (Esping-Andersen 1985: 33; Esping-Andersen 1999: 78ff).

By engaging in the politics of decommodification, social democracy is therefore the natural political ally of classes that wish to hedge their risks. This match between the working class's interest-based claim for decommodification and social democratic policy accounts not only for simple electoral mobilisation, but also for the formation of the party's core constituency and its long-term mobilisation, as long as social democrats represent the politics of decommodification and pursue corresponding social and economic policies (Esping-Andersen 1985). Hence, the social democrats are seen to own the welfare issue, which binds them to their core electorate as long as the party is able to hold on to the issue via its programmes and policies (Blomqvist \& Green-Pedersen 2004).

However, not all voters are expected to have a strong preference for decommodification. Originally, Esping-Andersen (1990:22) regarded employers as the main opponents due to their economic interests, especially their weakened bargaining power if decommodification is institutionalised. This perspective can be extended to particular groups of wageearners. Breen (1997) has argued that some occupational groups do not prefer the decommodification of labour, as they have more to gain from market-based arrangements given their assets and/or a fortunate bargaining position in the labour market, implying higher remuneration. These are typically wage-earners endowed with scarce but highly demanded skills and qualifications, who would lose parts of their income if the decommodification of other wage-earners were realised by means of high tax burdens for the well-off (see also Korpi 2006). 
On that score, the present book's theoretical model of voting and the arguments to follow below are embedded in the partisan politics theory. In this perspective, political parties represent the socio-economic interests of their social constituencies (e.g. Hibbs 1977; Schmidt 1982; Korpi 1983, 2006; Esping-Andersen 1985). This theoretical approach - and its related variant, power resources theory - argues that socio-economic interests are class-based, since working class voters demand a generous and encompassing welfare state to compensate for their weak resource endowment and to alleviate their exposure to market risks. Social democratic and other leftist parties were thus the natural allies of workingclass voters. By contrast, middle-class voters, the self-employed and capital owners were represented by secular bourgeois parties that advocated leaner welfare states to reduce the tax burden for their constituents and to enhance economic competitiveness. Christian democratic parties were able to attract voters from both the working and the middle class, given their cross-class appeal that sought to find a compromise between the interests of business and labour (van Kersbergen 1995).

While originally focused on explaining the emergence of the welfare state and different welfare state regimes (Esping-Andersen 1990; Korpi 2006; Manow 2007), partisan politics theory also provides a policy-based explanation for class-based party alignments and therefore a microfoundation for patterns of class voting (see Korpi 2006, esp. 172ff). The policy preferences of working-class voters account for their alignment with social democracy, this being the party family that reflects these policy preferences in its welfare and economic policies (Hibbs 1977; Schmidt 1982; Korpi 1983; Esping-Andersen 1985). Furthermore, the partisan politics perspective provides a dynamic perspective on class-based party allegiances, as voters located in classes are tied to parties due to policy preferences given their risk exposure and not due to the class location per se (Korpi 2006). As I outline in detail below, this means that parties' changing policy positions and the break with previous policies may cause dealignments of hitherto stable social constituencies.

Given the book's focus on social policy reforms and their effect on the commodification and decommodification of labour, I take the partisan politics approach to political behaviour as the theoretical point of departure for the arguments in the following sections. Moreover, applying partisan politics theory is not generally incompatible with more recent approaches to the study of electoral behaviour, such as issue voting or proximity voting. This will be briefly addressed in Section 2.5 . 


\subsection{Welfare state reform as a catalyst for partisan dealignment}

For Esping-Andersen (1985: 35), social policy not only accounts for partisan alignments, it can also foster the opposite development, namely partisan dealignments and realignments. By 1985, Esping-Andersen had already delineated the electoral risks of policy change for social democratic parties. If social democratic parties were to engage in policy change that went against the economic interests and social policy preferences of their core constituency, they would risk alienating these voters. The voters might not only dealign from the party, but might also realign with challengers that appealed to them by offering credible policies.

Esping-Andersen (1985) used Danish social democracy's electoral misfortunes during the 1970 as an example. In contrast to its Norwegian and Swedish sister parties, the Danish social democratic party had trouble maintaining high and stable support among its core constituency. One reason was that Danish social democracy (SD) had joined political agreements that liberalised the Danish housing market during the $1950 \mathrm{os}$ and 1960s (ibid: chap. 6). This created a divide not only between owners and tenants, but also within the social democratic core constituency. The Socialist People's Party spoke for the tenants and argued that they had been disadvantaged by the SD's policy. This continued in the 1970s, when by trying to reduce the homeowners' tax privileges, the SD split its own voter base, as many workers had bought houses during the phase of liberalisation. The Socialist People's Party reinforced its position among the tenants, whereas the SD suffered a weak electoral performance and saw its right wing break out to form a new party, the Centre Democrats.

The SD's tax policy underwent a similar development in the same period. At that time, the tax burden in Denmark was among the fastest growing in the world, and the social democratic expansion of the welfare state produced equity conflicts in the Danish electorate. Workers were also concerned by the high tax burden, and some workers became disaffected with the social democrats and their welfare policy as other societal groups benefited from the expansion of the welfare state (EspingAndersen 1985, esp. chap. 8). These voters turned to the new protest party 'Fremskridtspartiet' (the Progress Party) in the 1973 election and the remainder of the 1970s. The SD was weakened in this period as its policies went against the economic interests of its own core constituency, which defected to parties on the margins.

By contrast, the Norwegian Labour Party and the Swedish social democrats avoided dividing their electorate as a consequence of their housing 
policies or tax policies, as well as the increased and cross-cutting political salience of those issues. As they did not engage in policies that went against the social policy attitudes of their core constituencies, they held on to these voters. Esping-Andersen's explanations of electoral change are thus policy-based. He theorised and demonstrated the feedback effects that occur when social democrats engage in policies that conflict with the interests of their core voters and their own historical principles.

Similar arguments apply when we theorise the electoral consequences of Third Way welfare state reforms. As the Third Way implied a departure from basic social democratic principles, as I will outline below, we can expect this paradigm shift to produce electoral risks for social democracy. This is particularly true for the decommodification principle, which has been identified as crucial for the alignment of the core constituency, but which was violated by Third Way reforms.

Given the social democratic core constituency's aspiration for decommodification, policies that reflect a recommodification of labour are simply not in line with the interests and preferences of the party's core constituency. Consequently, if social democrats engage in policies that deviate from the politics of decommodification, they face a serious electoral risk (Esping-Andersen 1985: 148f). This implies not only short-term effects due to dissatisfaction, but also a dealignment of the party's core electorate; or, in Esping-Andersen's words, a 'social democratic decomposition' (ibid: 35 ) as the voter-party mechanism is suspended. In other words, social democracy is in danger if it loses the welfare issue due to a policy change (Blomqvist \& Green-Pedersen 2004: 597f). This also implies that Ross's claim about the effect of issue ownership which prevents an electoral setback for social democrats may be too static and does not secure blame-avoidance at the very end.

As pointed out, a decommodifying welfare state and its social policy are characterised by generous and unconditional benefits as well as high replacement rates to reduce the individual's reliance on the market as the main source of income and to protect his or her skills and assets. More concretely, Esping-Andersen (1990: 47) has spelled out an operationalisation of social policy in terms of decommodification and recommodification that will be applied in this book and described in more detail in Chapter 3.

Esping-Andersen refers to three dimensions of commodification. He first considers the accessibility of benefits; that is, eligibility rules and restrictions on entitlements. Decommodification is ensured if there is easy access to (generous) social security schemes and if this access is not 
contingent on previous contributions or employment records, labour market attachment or means-testing. Similarly, eligibility is not restricted through entitlement periods. Recommodification means that the right to benefits from a social security scheme is contingent on previous contributions or employment records, means-testing, labour market attachment or other types of restrictions. Limited and shortened eligibility periods also indicate recommodification. Likewise, recommodification is reinforced if these principles are reinforced by legislative changes.

A second dimension concerns the degree of income maintenance. Decommodification is reflected by having a large share of one's former income replaced by high benefit levels to secure a sufficient standard of living. Recommodification occurs if benefit levels do not match a sufficient share of former income and benefits fall considerably below average earnings, which forces the unemployed back to the market quickly. The third dimension is the universality of entitlements. A guaranteed citizens' wage would reflect a very high degree of decommodification, whereas restricted and particularistic schemes indicate the opposite.

Accordingly, reforms that introduce less generous benefits, and tightened eligibility and suitability criteria, make benefits more conditional, and reduce replacement rates clearly mark a departure from the politics of decommodification. By implementing these policies, social democrats risk losing their core constituency, which, as outlined above, has a preference for the decommodification of the wage-earner.

Having outlined Esping-Andersen's arguments on the various aspects of decommodification, I now embed the policies implemented under Third Way agendas into the framework to demonstrate that the Third Way indeed produced a potential dealignment between social democracy and its core constituency.

Comparison of traditional social democratic and Third Way social policy

This section contrasts the social policies of social democracy before and under the Third Way, showing why social democracy risked a dealignment of its core constituency as a consequence of Third Way policies.

The Third Way was responsible for a recommodification of the wageearner, since many social policy arrangements and provisions were reformed in ways that conflicted with social democracy's traditional notions and principles. In contrast to the decommodification principle, Third Way social policy reforms enforce labour market participation by creating incentives to enter (or re-enter) the labour market and not to rely on 
benefits over long periods. This was typically implemented by means of stricter eligibility criteria, shorter entitlement periods, tighter suitability criteria and less generous benefits, in particular lower replacement rates (e.g. Green-Pedersen et al. 2001; Bonoli 2004; Powell 2004; Dingeldey 2007). Furthermore, Third Way reforms introduced means-testing for social benefits, which is in line with prioritarian egalitarianism. The main recipients of benefits were no longer the working class, in line with the notion of wage replacement, but other marginalised social groups, as a means of poverty alleviation. More generally, a social investment state was to replace the old welfare state (Keman 2011).

The contrast between Third Way reforms and old social democratic principles and policies in labour market and social policy is illustrated in Table 2.1.

It is obvious that the measures implemented under Third Way agendas contradict traditional social democracy's principles and policies in labour

Table 2.1 Social and labour market principles and policies under traditional and Third Way social democracy

\begin{tabular}{lll}
\hline & Traditional Social Democracy & Third Way Social Democracy \\
\hline & Egalitarianism & Prioritarian Egalitarianism \\
Solidarity & Productivist Solidarity \\
Frinciples & Traditional Welfare State & Focus on Equality of Opportunity \\
& Rights & Social Investment State \\
& Universalism & No rights without responsibilities \\
Security & Mix universalism and selectivity \\
\hline & Welfare without work: passive social & Conditionality and Active Labour \\
security benefits & Market Policies \\
High services and benefits & High services but low benefits \\
High replacement rates (especially for & Lower replacement rates or even flat- \\
core work force) & rate benefits \\
Lenient eligibility criteria for social & Tightened eligibility criteria \\
security benefits & \\
Long or unlimited eligibility period for & Shorter eligibility periods for benefits \\
benefits & $\begin{array}{l}\text { (often accompanied by mandatory } \\
\text { activation) }\end{array}$ \\
\hline No or moderate Job Suitability Criteria & Tight Job Suitability Criteria \\
\hline
\end{tabular}

Source: Own compilation drawing on Green-Pedersen et al. (2001); Bonoli 2004; Powell 2004: Table 1.1; Dingeldey 2007; Keman 2011. 
market and social policy. The table's upper half shows that the Third Way transformed many traditional social democratic principles. The lower half demonstrates that this was accompanied by considerable policy changes. Most importantly, decommodification was suspended by Third Way social democracy, since access to benefits was no longer an unconditional social right, but limited by eligibility and conditionality. In this respect, the (re-)commodification of labour as the enforcement of labour market participation was an explicit Third Way goal (e.g. Green-Pedersen et al. 2001; Huo 2009).

Consequently, this book will explicitly study the actual policy changes implemented by social democratic parties to assess whether actual labour market reforms did indeed depart from traditional social democratic policies. In other words, the analysis of the reforms will investigate whether the policy change illustrated in the lower half of Table 2.1 took place under social democratic governments. Admittedly, such an approach implies a rather narrow focus on Third Way reforms. Nevertheless, this operationalisation captures the core of Esping-Andersen's notion of decommodification. Looking at actual policies captures the issue of whether labour is commodified or protected against the risks of the labour market through social security arrangements. This cannot be ensured by only analysing manifestos, as these might announce policy changes that were never realised in the political praxis or leave out policy changes that were actually realised. I will nonetheless briefly review party constitutions and analogous statements to identify the parties' ideological stance on social policy in terms of my framework. The issue of analysing labour market reforms will be further discussed in Chapter 3 .

In sum, having engaged in welfare state reforms under the Third Way paradigm, social democrats no longer fulfil the conditions for the longterm alignment of their core constituency, since the reforms go against the social policy demands of their traditional supporters. The Third Way aimed to enhance labour market participation by means of active labour market polices, which made benefits contingent on the individual's willingness to take up work or training. Moreover, replacement rates were decreased (at least in the long run) and opportunities to leave the labour market with a relatively high share of one's former income were considerably reduced. In particular, Merkel et al. (2008: 14) claim that 'the decommodification objective has been partially substituted by a principle of conditionality' (cf. Dingeldey 2007: 823 for a similar summary). Hence, the essential argument is: by introducing recommodifying reforms under the Third Way, social democrats violated their original programmatic as- 
pirations and thus risked alienating their core constituencies. The main proposition to be examined is: social democratic parties that engage in the recommodification of labour risk alienating their core constituencies, as these reforms conflict with the social policy preferences of these voters.

\subsection{Decommodification, social class and conceptualising the social democratic core constituency}

This section conceptualises the notion of the social democratic core constituency to be applied in the empirical analysis. It operationalises the argument, made by Esping-Andersen and others, that the preference for decommodification is class-based and thereby explains the alignment between particular classes and social democracy. In this respect, it is fruitful to draw on a class concept that takes the individual's position in the labour market, skills and the resulting claim for protection against risks into account (Korpi 2006). The notion of 'risk classes' is the crucial underlying rationale (Baldwin 1990; Esping-Andersen 1999: 4of) and allows us to delineate those classes that originally formed the social democratic core constituency to give us an analytical construct for the empirical investigation. One such conception is the class scheme proposed by Erikson, Goldthorpe and Portocarero (e.g. Erikson \& Goldthorpe 1992; Goldthorpe 2007) - henceforth the EGP scheme - which systematically incorporates the human capital of wage-earners, employers and the self-employed. As mentioned above, human capital in terms of assets and skills and the resulting position in the labour market are the important aspects of an individual's desire for decommodification. Moreover, individuals with typical wage relationships should be most concerned with decommodification (Esping-Andersen 1999: 45; see also Korpi 2006: 172ff). In this regard, the EGP scheme accounts for human asset specificity influencing type of work contract, chances of promotion and risk of redundancy, and classifies occupations in terms of these factors (see Goldthorpe 2007). In my opinion, this class scheme is appropriate for classifying claims for decommodification, and I argue that classes with a labour contract and low human capital have formed the social democratic core constituency via the decommodification linkage.

The EGP scheme can be seen as the basis for a more systematic treatment of occupations than Esping-Andersen's original work, which mainly drew on labour force statistics to distinguish classes. The EGP 
scheme enables a coherent operationalisation of individuals' decommodification claims in line with Esping-Andersen's arguments. More generally, the scheme allows us to test the arguments drawn from the partisan politics literature on the social policy preferences of different social constituencies with individual-level data. Table 2.2 lists the classes distinguished by the EGP scheme, their endowment with human capital, differentiation of employment contracts, and expected claims for decommodification.

The classes IIIb, VI and VII, manual workers and lower-white collar employees, exhibit features that lead to a claim for decommodification, as they have labour contracts and only limited human capital. This is in accordance with both Esping-Andersen's theoretical claims for social democratic class alignments (1985: chap. 1) and the descriptive analysis on the

Table 2.2 EGP-Class, labour market position and claim for decommodification

\begin{tabular}{|c|c|c|c|c|}
\hline Class & & $\begin{array}{l}\text { Type of } \\
\text { employment } \\
\text { contract }^{a}\end{array}$ & $\begin{array}{l}\text { Endowment with } \\
\text { human capital }\end{array}$ & $\begin{array}{l}\text { Claim for } \\
\text { decommo- } \\
\text { dification }^{b}\end{array}$ \\
\hline I & $\begin{array}{l}\text { Professionals and managers, } \\
\text { higher grade }\end{array}$ & $\begin{array}{l}\text { Service } \\
\text { relationship }\end{array}$ & High & No \\
\hline II & $\begin{array}{l}\text { Professionals and managers, } \\
\text { lower grade; technicians, } \\
\text { higher grade }\end{array}$ & $\begin{array}{l}\text { Service } \\
\text { relationship } \\
\text { (modified) }\end{array}$ & High & No \\
\hline IIla & $\begin{array}{l}\text { Routine non-manual } \\
\text { employees, higher grade }\end{array}$ & Mixed & Low-Intermediate & No \\
\hline IIIb & $\begin{array}{l}\text { Routine non-manual } \\
\text { employees, lower grade }\end{array}$ & $\begin{array}{l}\text { Labour } \\
\text { (modified) }\end{array}$ & Low & Yes \\
\hline IV & $\begin{array}{l}\text { Small proprietors and } \\
\text { employers and self-employed } \\
\text { workers }\end{array}$ & Self-employed & Not classified & No \\
\hline V & $\begin{array}{l}\text { Technicians, lower-grade; } \\
\text { supervisors of manual workers }\end{array}$ & Mixed & $\begin{array}{l}\text { Intermediate- } \\
\text { High }\end{array}$ & No \\
\hline VI & Skilled manual workers & $\begin{array}{l}\text { Labour } \\
\text { (modified) }\end{array}$ & Low & Yes \\
\hline Vlla & $\begin{array}{l}\text { Non-skilled manual workers } \\
\text { (other than in agriculture) }\end{array}$ & Labour & (very) Low & Yes \\
\hline VIllb & Agricultural workers & Labour & (very) Low & Yes \\
\hline
\end{tabular}

Notes: a. Classified according to Goldthorpe (2007).

b. Own classification following Esping-Andersen (1985: chap. 1; 1990, 1999: chap. 3); modified means that labour contract accounts for some specific individual skills. 
class distinctiveness of Scandinavian social democrats in the post-war era (1985: 122ff). The EGP scheme has two main virtues. First, it theoretically distinguishes classes based on their position in the labour market, which conditions claims for decommodification. Second, this allows us to identify the social democratic core constituency in line with EspingAndersen's decommodification linkage. It also distinguishes other social classes opposing decommodification on the basis of their own economic interests, given their human capital and highly marketable skills. These individuals should benefit from commodification as an effect of their labour market position and are thus distinguishable from social democracy's core constituency.

Research on social policy preferences and attitudes towards the welfare state has shown that manual workers and lower white-collar employees have the strongest affiliation to social protection, income maintenance and egalitarian policies (e.g. Goul Andersen 2003b; Svallfors 2006; Edlund 2007). In line with Esping-Andersen, manual workers, and to a lesser extent lower-white collar employees, have had a significantly higher propensity to vote for social democratic or labour parties in recent decades (e.g. Manza et al. 1995; Evans 1999; Brooks et al. 2006; Knutsen 2006; Merkel et al. 2006: 8off; Bartolini 2007). Using the EGP class scheme or similar classifications of occupational groups, the literature has demonstrated that in several Western countries, unskilled and skilled workers, as well as the lower non-manual strata, could be identified as the social democratic core constituency until the 199os.

One might object that changing social policy attitudes and political preferences among the social democratic core constituency paved the way for Third Way reforms. If social democratic voters had developed more meritocratic attitudes in the years preceding the Third Way, the electoral risk of recommodifying reforms might have been alleviated. In a similar vein, less egalitarian social policy preferences among the electorate may have eased social democracy's electoral trade-offs in switching to a more market-oriented Third Way agenda.

The work of Svallfors (2006: chap. 5; 2007) and Edlund (2007) has analysed data on social policy attitudes and attitudes towards redistribution collected around the turn of the millennium, and thus during the initial phase of the Third Way. Using a similar class scheme to that presented in Table 2.2 above, the analyses reveal that there is still a considerable class cleavage on socio-economic issues such as the welfare state's generosity, taxation, redistribution and acceptable wage inequalities. Working class and routine non-manual employees are most supportive of a welfare state 
that secures generous and encompassing social security benefits and the public (rather than private) provision of welfare services. The same goes for state intervention in markets and the correction of market outcomes. These occupational groups are less tolerant of large income differentials than other groups with more marketable skills, and want to maintain existing decommodifying welfare schemes in line with the arguments made in sections 2.2 and 2.3. Hence, one can hardly say that social democratic core voters had become heavily inclined towards meritocratic ideals by the change of the millennium, as demonstrated by Svallfors' and Edlund's analysis.

Similarly, Boeri et al.'s analysis of survey data on attitudes towards welfare state retrenchment (2001) has shown that the lower social strata object to reforms and the retrenchment of the welfare state, even in an age of fiscal austerity. These patterns will be confirmed by analysing the attitudes towards welfare reform proposals in the case study chapters below. In sum, around the turn of the millennium, the occupational groups conceptualised as the social democratic core constituency still demonstrated strong egalitarian preferences, were inclined to support generous and encompassing social security benefits, and rejected proposals to reform the welfare state. Therefore, while social policy preferences might have changed between the Golden Age and the 1990s, the social democratic core constituency continued to harbour attitudes that implied a serious electoral backlash for social democratic parties that moved away from their traditional social policy principles. In this respect, Edlund (2007: 69 ) has stated 'that inertia, not change, is the most likely outcome as far as the contemporary development of political cleavages [around socioeconomic issues, CA] is concerned'. This also means that the partisan politics approach to electoral behaviour, as applied in this book, still has its merits, because it is possible to distinguish social classes by their demand for decommodification and link this to party choice and electoral change.

Given the theoretical and empirical evidence, I conceptualise the social democratic core constituency as consisting of manual workers and lower white-collar employees. This implies that I often use a straightforward twofold or threefold definition of the electorate in the empirical analyses. This is, of course, a rather simple operationalisation of social groups given the heterogeneity of the workforce and the discussion on new class divisions within the workforce (e.g. Müller 1999; Kitschelt \& Rehm 2005; Oesch 2006). On the other hand, this approach employs a theoretically stringent and clear concept to study voter alignments over time and space. I am aware that this also implies a loss of information, 
but as not all data sources used in this book allow for the use of more elaborate class schemes, my operationalisation is sufficiently distinct, as the above-cited research on social policy preferences and voting behaviour has shown. Moreover, related research on social democracy and the insider-outsider problem has often applied similar parsimonious operationalisations of the workforce to study dynamics over time or space (e.g. Rueda 2005, 2006, 2007; Lindvall \& Rueda 2012). Further research on the electoral consequences of Third Way reforms must, of course, dig deeper by using more fine-grained class operationalisations and testing new class schemes.

Returning to the general claim that recommodifying reforms imply a risk of an electoral setback for social democracy, the next section discusses the role of the electoral system and competitor parties. On the basis of this discussion, some arguments are elaborated for the expected patterns of electoral consequences of the reforms in a given context.

\subsection{Political system, party competition and welfare reforms}

The impact of the electoral system for the electoral effects of the reforms

The argument made in this section is that the electoral effects of welfare reforms in FPTP systems are different from those in PR systems, because FPTP protects reform-minded social democrats from being challenged by competitors on the margins or other welfare parties. One should note that both the arguments on electoral consequences made below and the book's analytical focus in general refer to those social democratic parties that held office and were responsible for welfare state reforms. Analysing the electoral fortunes of those parties that were out of office at that time is beyond the scope of the book, although recent developments in the Swedish case for the oppositional social democrats will be discussed in Chapter 7.

FPTP systems typically produce single-party governments with competition between two major parties or between two major parties and a minor third party with regional (or other socially defined) strongholds that allow it to survive. Scholars of welfare reform often embed this feature in veto-player logic and argue that welfare state retrenchment can be pursued more easily under Westminster-style FPTP systems (Kitschelt 2001a; Starke 2008, esp. 3of, 196ff). It is easier for established parties to imple- 
ment otherwise unpopular reforms and cutbacks, since leftist or Christian democratic pro-welfare parties that may block reforms or gain votes afterwards remain marginalised. The same is true for the radical right or other types of protest parties.

The absence of such challengers in parliament and the electorate's knowledge about the ineffective support for these parties make reforms more likely under FP TP systems. Starke (2008: 208) claims that FPTP is the strongest institutional determinant for retrenchment, especially when social democrats support the reforms (such as New Zealand's Labour Party in Starke's case). As the main opponent of the social democrats is a market-liberal conservative party, which cannot credibly oppose or block the reforms, they have relatively broad leeway to implement their policies. Disaffected core supporters can only abstain or vote for ineffective leftist parties (Kitschelt 2001a: 283). The dependent variable in this literature is the likelihood of welfare state reforms. I claim that the arguments can be rewritten to predict the electoral consequences of reforms and the role of the electoral system in a first step, and the importance of particular parties in a second step.

In other words, the arguments can be used to theorise the electoral system's impact on the electoral effects of the reforms under an FPTP system, in contrast to those countries that use PR. As the electoral system effectively prevents the emergence of serious challengers to Third Way social democracy, and the second mainstream party is not credible, the electoral trade-off for reform-minded social democrats is reduced to a non-voter dilemma. In an FPTP electoral system, abstention on the part of reform-averse core constituents should be the typical electoral effect of recommodifying welfare state reforms implemented by social democrats.

This effect was confirmed by Kriesi and colleagues' examination of the role of globalisation in electoral change (Kriesi et al. 2008). Examining the establishment of right-wing parties in the context of globalisation, Kriesi et al. (ibid., esp. 38ff) claimed that the established parties in the UK were not seriously challenged by this type of contender thanks to the FPTP system. By contrast, during the past three decades of increasing globalisation, countries with PR systems have typically seen the rise or emergence of parties on the political margins.

Nevertheless, if a country with an FPTP system has a third party that challenges the two major parties, such as the Liberal Democrats in the UK, some social democratic core voters may shift to this relatively marginalised party if there is a realistic chance that it might win in the respective constituencies. In the British context, the Liberal Democrats 
have often attracted voters who are dissatisfied with both Labour and the Tories (as the party positioned itself in equidistance until the mid-199os). Moreover, its regional strongholds in England's south-west and southeast, as well as Scotland, allowed it to survive against an oversimplified interpretation of Duverger's law. Thus, apart from the non-voter tradeoff discussed above, the existence of a centrist minor third party under FPTP needs some empirical inspection to see whether this produces a diverging effect against my general claim of the dealignment of social democratic core voters under FPTP as a consequence of recommodifying reforms.

Having borrowed the arguments from both the retrenchment literature and the party competition literature, I argue that an FPTP system basically leads to a dealignment of social democratic core voters after recommodifying reforms have been implemented by 'their' party. We should not expect considerable realignments with other parties, as these are marginalised by this electoral system and voters are aware that shifting to non-established parties means a wasted vote. I thus expect that the electoral system conditions the electoral consequences of the reforms, as while social democracy is only threatened by dealignment under FPTP systems, it faces challenger parties under PR that implies realignment to other parties.

Figure 2.1 summarises these expectations in a highly stylised fashion.

Figure 2.1 Role of electoral system for main electoral effects of welfare state reforms

\begin{tabular}{|lll|}
\hline $\begin{array}{l}\text { Reforms } \\
\text { No }\end{array}$ & FPTP & PR \\
Yes & Core constituency sticks to party \\
& Dealignment (abstention) & Realignment (gains for \\
& & competitors) \\
\hline
\end{tabular}

This brings us to the question of what happens if the electoral system is PR and thus does not prevent reform-minded social democratic parties from being challenged by other parties as a consequence of the reforms.

Competitor parties for social democracy after Third Way reforms under PR

This section develops the arguments relating to which competitor parties are most dangerous for social democrats reforming the welfare state, and under which conditions. Of course, non-voting remains an option 
for dissatisfied social democratic voters under PR systems, but the crucial difference is the likelihood of realignments to dangerous challengers that are not marginalised by the electoral system. ${ }^{1}$ My main argument is that leftist challengers represent the first type of dangerous competitor and authoritarian right-wing parties the second type. Further arguments concern the role of other mainstream parties and the electorate's credibility considerations regarding these challengers.

\section{Challenge from the left}

Esping-Andersen (1985) maintained that the most serious competitor for a social democratic party that has implemented recommodifying welfare reforms is a party to its left. Similarly, Kitschelt (2001a: 276) claimed that due to their stance on welfare policy, these parties 'are likely to become the recipients of disappointed social democratic voters'. Thus the retrenchment literature saw leftist parties as veto players, as they constitute an electoral dilemma for reform-minded social democrats in advance (Kitschelt 1999, 2001a; Merkel et al. 2006, 2008). Moreover, due to their programmatic stance, they are not only a short-term threat.

This problem has also been identified in earlier research on social democracy (Przeworski 1980, 1985; Przeworski \& Sprague 1986; King \& Wickham-Jones 1990). This literature generally discussed the electoral dilemmas relating to different strategic options: whether a social democratic party should be an orthodox working-class party or a party with broader societal appeal, as it later aspired to implement a Third Way agenda. Social democrats would risk losing working-class voters to other class-based parties, such as communists and left-socialists, if they became more moderate and broadened their appeal to attract middle-class voters (Przeworski \& Sprague 1986: 55f, 7off; King \& Wickham-Jones 1990: 390). Competition from the left thus constitutes a serious electoral trade-off for social democrats that wish to appeal to the centre, as their working-class constituencies are now ideologically closer to the left-wing challenger.

In this respect, left-wing parties do not only pose a short-term threat, as they particularly attract the (former) social democratic core constituency, which demands risk-hedging welfare policies. Such parties also advocate universal and generous social security schemes with a high degree of income replacement. Accordingly, they reflect the attitudes of social democratic core constituents and may try to mobilise these voters with their stance on welfare. In this respect, communist or leftist socialist parties may present themselves as 'original' social democrats after the social 
democrats have adopted Third Way agendas and moved towards the ideological centre (Arter 2002; Blomqvist \& Green-Pedersen 2004; Volkens 2004). Left-wing competitors therefore have a chance to draw on the decommodification mechanism that originally tied the social democrats to their core constituency, to foster electoral realignment after welfare state reform has taken place.

Although the present book takes arguments from the partisan politics literature as its theoretical point of departure, the danger of left parties (as well as other challengers) can also be conceptualised from the perspective of issue voting theories. The arguments from the perspective applied in this book are by no means contradictory to or mutually exclusive of arguments from the issue voting literature. Even if political competition is increasingly structured around issue competition, 'there is no reason to assume that a responsive electorate is inconsistent with substantial class differences in party preference' (Evans \& Tilley 2012: 141).

In short, the issue voting literature assumes that voters elect political parties or politicians on the basis of their perceived competence on salient issues on which they have developed policy preferences (Budge \& Farlie 1983; Petrocik 1996). Moreover, parties own particular issues: social democratic parties have built a reputation on welfare issues and fighting unemployment, whereas centre-right parties are typically regarded as fiscally prudent and able to enhance competitiveness (e.g. Budge \& Farlie 1983; Petrocik 1996). The fact that social democrats have traditionally 'owned' the welfare issue due to their function as an advocate of welfare state development has also been used as an argument for why social democrats have more leeway in reforming the welfare state (Ross 2000; Green-Pedersen 2002a). However, stable issue ownership for social democrats due to previous policies is a rather static assumption, and disregards the position of left-wing competitors under conditions of issue competition after social democracy has shifted to a Third Way policy platform, as argued above. On that score, social democrats may lose the welfare issue that they traditionally owned (Blomqvist \& Green-Pedersen 2004). As a consequence of Third-Way-induced policy change, left-wing competitors can take over the welfare issue from the social democrats and win voters who prioritise welfare, something that is particularly true for the social democratic core constituency. The welfare state and the fight against unemployment have typically been highly salient issues in Western European electoral contexts (Aardal \& van Wijnen 2005), and this should particularly be the case when policymakers adopt policies that depart from their parties' traditional issue reputations. In this vein, 
arguments from the issue competition approach provide a different linkage between partisans and parties, but not one that is incompatible with the partisan politics literature, as both use voters' policy preferences as a common core for theorising partisan alignments. ${ }^{2}$

Moreover, in the language of spatial models of party competition, leftist parties may now occupy the gap on the left where the more centrist Third Way reform agenda should have created a vacuum (Neugebauer \& Stöss 1999; Arter 2002; Blomqvist \& Green-Pedersen 2004; Patton 2006; Allen 2009). A left-wing challenger can now be used for compensational or directional voting as former social democratic voters are punishing their parties by shifting to parties that are closer to their policy positions (Adams et al. 2005; Kedar 2005). Summing up the theoretical arguments, we can expect left-wing (socialist) parties to constitute dangerous competitors for reform-minded social democrats. As a consequence of recommodifying welfare reforms, these parties may draw on the welfare link that originally tied social democracy to its core constituency and therefore foster a realignment of this voter segment. Furthermore, these parties are not expected to engage in retrenchment given their position on social policy issues, making them credible alternatives for the social democratic core constituency. On the other hand, if they were previously involved in welfare state reforms or advocate future reforms, they may have seriously damaged their credibility. This will be addressed below.

\section{Challenge from the right}

The literature also maintains that right-wing parties are increasingly challenging social democracy, as they typically attract the same segment of voters as social democrats do (cf. Kitschelt 2007 for an extensive literature review). These arguments often refer to Lipset's classic thesis (1981) on working-class authoritarianism; that is, a cross-pressure effect for workers who are leftist on economic issues but rightist on socio-cultural issues. As I will argue in this section, this can also be linked to the Third Way. For the sake of clarity, I exclude traditional conservative and marketliberal parties here, and mean parties of the new right or far right when I refer to 'right-wing parties'.

Authoritarian right-wing parties are serious challengers to social democratic parties, as they represent the attitudes of social democratic core voters on socio-cultural issues such as the environment, immigration or law and order (Kitschelt 2001b; Scheuregger \& Spier 2007; Houtman et al. 2008; Kriesi et al. 2008). The authoritarian attitudes of the 
manual classes bear the potential for realignments with parties on the right (Kitschelt 2001b; Achterberg 2006; van der Waal et al. 2007; Kriesi et al. 2008).

Given these arguments, there are strong indications that right-wing parties constitute dangerous challengers to Third Way social democracy. Once the welfare link between social democracy and its core constituency is broken, right-wing parties may foster realignment with social democracy's core constituency, basing their attitudes on socio-cultural issues. More generally, the Third Way has a more centrist electoral appeal, which implies that social democratic and mainstream centre-right parties, such as Christian democrats, converge on the welfare economics dimension (Keman et al. 2006; Huo 2009). In this respect, cultural voting benefits right-wing challengers (Kitschelt 1997; Carter 2005: 206ff; see also Kitschelt 2001b: 431f; Achterberg 2006; Houtman et al. 2008; van der Waal et al. 2010). This danger is particularly virulent if the right-wing party itself takes a social protectionist stance by defending core social security schemes to attract working class constituencies that oppose welfare reforms (Kitschelt 2003, 2004). Kitschelt (2001b: 435) has proposed that far right parties could turn into post-industrial labour parties, to the detriment of social democratic parties.

Following these lines of reasoning, I argue that Third Way reforms provide a favourable context for the realignment of social democratic core constituents with authoritarian right-wing parties. However, I claim that it is not the cultural dimension per se that causes the realignment, but rather the reforms themselves, because the latter break the ties between social democracy and its core voters and trigger the shift to right-wing parties, provided these are not (distinctly) anti-welfare. Of course, these parties may now capitalise on their position on cultural issues, once social democracy is no longer able to hold on to its voters with social policy.

However, there has been substantial variation in the success of authoritarian right-wing parties in Western countries (e.g. Kitschelt 1997, 2007; Arzheimer \& Carter 2006; Stöss 2006). Some countries have seen the emergence and electoral breakthrough of such parties, whereas other countries have not. This is of particular importance in the case of Germany, one of the cases in this book. In contrast to many neighbouring countries, there was neither a far right party at the federal level before the SPD adopted a Third Way agenda nor after the SPD gained office in 1998 (Dolezal 2008). This needs to be discussed briefly in order to clarify why the chapter on Germany is almost exclusively focused on competition from the left. 
The existing German far right parties - the German People's Union (DVU), the National Democratic Party (NPD) and the Republikaner were by no means successful competitors at the federal level during the period under review, as they never came close to surpassing the threshold for parliamentary representation and did not pose a dangerous challenge to the established parties. ${ }^{3}$ This is because they either declined to compete due to internal struggles at that time (Republikaner), or were still associated with the national socialist legacy (DVU and NPD) (Stöss: 2006: 555ff). ${ }^{4}$ Moreover, the two parties did not distance themselves from this legacy in an authentic manner, but rather remained ambivalent in public appearances or even cooperated with violent extremists. This has led to the enduring political marginalisation of the DVU and NPD and to only occasional electoral gains in second-order elections. Moreover, the DVU and NPD belong to the extreme right, and not to the family of socalled populist or new right parties, such as the Danish People's Party or the Norwegian Progress Party, which have been far more competitive in recent decades (e.g. Stöss 2006; Dolezal 2008: 218). The NPD was even threatened with being banned in 2001, due to its suspected opposition to the German Constitution and its affiliation with the national socialist legacy. Given these arguments and the outright failure of the far right in the German case, the respective chapter is focused on the electoral challenge from the left for the reform-minded SPD after 1998. This marks a contrast to the Danish case, where a competitor from the right had electoral success during the period under review, and where the competitor did not hold extremist views that prevented the party from becoming competitive.

In sum, there is also serious potential for a realignment of social democratic core voters with authoritarian right-wing parties as a consequence of recommodifying Third Way welfare state reforms. Once such reforms have taken place, right-wing parties can attract this segment of voters with a combination of authoritarian socio-cultural appeal and a social protectionist stance on welfare. The two sections above on left- and rightwing competitors yield the following proposition: pro-welfare leftist and authoritarian right-wing parties constitute the most dangerous challengers for reform-minded social democrats under PR.

\section{Credibility considerations and the prospects for challenger parties}

Having argued that leftist pro-welfare parties and authoritarian rightwing parties are the most dangerous challengers to reform-minded so- 
cial democrats, I nevertheless claim that some qualifications have to be made with respect to the competitors' actual electoral prospects. Realignments do not occur automatically; challengers must appear credible in terms of their own policy and their current political positions on social policy.

A crucial aspect for the credibility of challengers is whether they have 'dirty hands' from participation in previous retrenchment and reform. If potential competitors were part of a legislative or formal coalition that engaged in retrenchment and welfare state recalibration, they have already damaged their credibility. This effect has been demonstrated by Heinisch's analysis (2003) of the Austrian Freedom Party (FPÖ). Having attracted large shares of working class votes during the 1990s, the FPÖ lost parts of its working class constituency in the 2002 election after implementing controversial welfare and tax reforms in coalition with the Christian Democratic People's Party (övp). The party could no longer exploit its anti-establishment appeal and 'clean hands' image, which had attracted working-class voters.

I make a similar point for the case of the Socialist People's Party in Denmark in this book. This party typically represents a left-socialist party that should have constituted a dangerous challenger for reform-minded social democrats, as outlined before. However, as the chapter on Denmark will show, the party gave parliamentary support to the social democratic minority government after 1994, a government that was responsible for three rounds of encompassing labour market reforms. The party failed to show credible opposition to the reforms and acted too compliantly to be seen as a credible challenger to the social democrats. In this vein, the party got 'dirty hands' by giving parliamentary support to a reform coalition and thus damaged both its credibility and its chance to win social democratic core voters at that time. This is different from the case of Germany, where we also find a left-socialist challenger, but a credible one. The Left Party that emerged during the period of welfare state reform in Germany under Chancellor Schröder was by no means involved in the legislation around the reforms and cuts, and therefore posed a credible challenge for the SPD. Thus, the cases of Denmark and Germany enable us to test the credibility argument by looking at the electoral fortunes of the left-socialist parties in these two countries, which differed in their political strategy during the respective reform periods.

Lastly, potential challengers that promote their own reform agendas damage their credibility and thus their prospects of attracting social democratic core voters. Under normal circumstances, these voters cannot be 
expected to shift to a party that proposes even harsher reforms than their traditional political ally. Hence, potential challengers to social democracy damage their credibility and weaken their chances of attracting social democratic core voters if they have 'dirty hands' or promote their own reform agendas. This can be summed up in the following proposition: challengers have to be credible and cannot have supported reforms in the past or plan to do so in the future.

\section{Mainstream parties as potential challengers}

To conclude the discussion on competitor parties for Third Way social democracy, I want to consider mainstream parties that have a reputation on welfare or try to abandon an anti-welfare image by counteracting a social democratic challenger's Third Way agenda with their own strategic move. They are typically, but not exclusively, Christian democratic parties. Christian democratic parties are seen as welfare parties that also advocate some degree of decommodification (Esping-Andersen 1990; van Kersbergen 1995), and thus constitute an electoral competitor for social democratic parties engaging in welfare state reform in a few countries. In opposition to reform-minded social democrats, they may benefit from public discontent about welfare reform due to their pro-welfare image and thus take over the welfare issue among some voters (Kitschelt 2001a; Schmidt 2006).

Similar points can be made if a social democratic party faces another mainstream party that is not distinctively anti-welfare and that moderates its appeal to incorporate workers and lower white-collar employees in its electoral considerations. Such parties may also benefit from disaffection with social democratic welfare state reforms, but it is more questionable whether this will lead to outright and lasting realignments. Like left-socialist and authoritarian right-wing parties, mainstream parties may benefit if their positions are close to those of the social democratic electorate, but they cannot be a credible alternative if these parties advocate conflicting positions. This may be the case if a mainstream party endorses its own reform agenda or takes a libertarian position on sociocultural issues. In contrast to their left-wing and right-wing opponents, who directly target working-class constituencies, the role of mainstream parties seems more ambiguous in terms of the electoral consequences of Third Way reforms. 


\subsection{Social democracy and declining class voting}

The claims outlined above have to be brought into the context of another apparent and probably the most obvious rival explanation, the postulated decline of class voting as a trend in modern societies. If this is true, classbased social democratic parties should lose support as a logical consequence of social change, which is presumed to be the driving force for the decline of class voting. The literature on the decline of class voting offers various explanations for the weakening effect of voters' social class background on vote choices and party alignments. More precisely, there are five discernable theories (Manza et al. 1995; Goldthorpe 1996; Evans 200o).

The first explanation points to the 'embourgeoisement' of the working class and the 'proletarianisation' of white-collar work as an explanation for declining class voting (e.g. Goldthorpe et al. 1968). This is supported by claims about increased occupational and social mobility blurring class effects on political choice (De Graaf et al. 1995).

A second line of reasoning has argued that new or re-emerging cleavages, such as gender, race, ethnicity or consumption, are replacing the hitherto dominant class cleavage as the predominant predictor for political behaviour (e.g. Dunleavy 1980; Huckfeldt \& Kohfeld 1989; Inglehart \& Norris 2000).

The third set of explanations relates to increasing levels of educational attainment and thus the 'cognitive mobilisation' of the electorate. Political preferences no longer originate from class-based social identities, but can increasingly be traced to rationality considerations and political learning processes. This leads to a decline in class voting, whereas issue voting and voting based on assessment are expected grow (e.g. Dalton 1984, 1996; Franklin 1985; Heath et al. 1991).

The fourth line of reasoning is probably the most influential and widespread explanation for the decline in class voting in Western societies: that the increasing importance of postmaterialist values has reduced the role played by materialist values in society (e.g. Inglehart 1984, 1990), and that voting decisions are therefore based on values rather than on class affiliations. The result is a division of the left into an old class-based left consisting of workers and a new postmaterialist left drawing support from the new middle class. This is said to weaken the traditional left-right division structured by class, while overall class voting is not expected to decline (e.g. Lipset 1981; Inglehart \& Rabier 1986; Weakliem 1991).

The fifth argument is that as the share of manual workers was never sufficient and has declined substantially, class-based social democratic 
parties cannot reach a majority based on their working-class constituencies. They thus have an incentive to broaden their appeal to the middle classes. This dilemma of electoral socialism has led to a general decline in class-based politics and has reduced the importance of class in the vote choice for social democratic parties (Przeworski 1980; Przeworski \& Sprague 1986; King \& Wickham-Jones 1990). Przeworski, Sprague and later Kitschelt further conceptualised the electoral trade-off faced by social democrats if they try to attract new voters outside their traditional core constituency by moving to the political centre (Przeworski 1980; Przeworski \& Sprague 1986; Kitschelt 1994, 1999). Since this requires compromise and reformist policies that do not reflect orthodox social democratic policies, the core constituency is likely to be alienated and its support to become uncertain.

These explanations typically concern the period prior to the Third Way; that is, the period between the 1970s and the early 199os. In this respect, the present book speaks in particular to the fifth type of explanation, because the origins of the Third Way lay in the kind of electoral dilemma that Przeworski and others referred to. Given the insufficient and declining number of workers in modern Western societies, social democrats had to broaden their electoral support to capture the centre ground and to mobilise new voters from other social groups, specifically the middle class (Kitschelt 1994; Giddens 1998; Huo 2009; Häusermann 2010). This would be realised by transforming social democracy's stance on various policy areas to appeal to middle-class voters, especially labour market policy. The very mechanism that tied social democrats to their core constituency - decommodification - was suspended by means of a serious policy change. Accordingly, we would expect electoral dilemmas to materialise under the Third Way.

Table 2.3 shows the share of the occupations in 1995 that I treat as the social democratic core constituency for the four cases examined and for other selected Western European electorates. It becomes clear that around 1995, manual workers and routine non-manual employees comprised what was far from being a non-negligible political group for social democracy. With the exception of the Netherlands, these occupations represented at least one-fourth of Western electorates at a time when most European social democratic parties had begun to transform themselves and re-calibrate their electoral messages under Third Way agendas. This is not to say that the changing occupational structure had no long-term repercussions for social democracy, as outlined in the previous passage, but it clearly illustrates that alienating the core constituency by 
implementing Third Way reforms implied a considerable weakening of social democracy's long-term electoral strength, as in 1995, every fourth voter still belonged to those occupational groups.

Table 2.3 Occupational composition of Western European electorates, 1995

\begin{tabular}{|c|c|c|c|c|c|c|c|c|c|c|}
\hline & 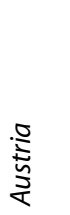 & 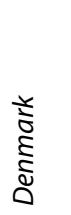 & $\frac{\substack{0 \\
\vdots}}{i=1}$ & 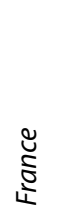 & 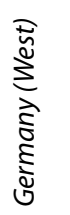 & 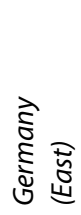 & 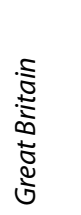 & 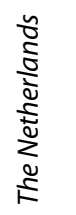 & $\frac{\grave{c}}{\grave{c}}$ & 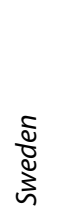 \\
\hline $\begin{array}{l}\text { Core } \\
\text { constituency }\end{array}$ & 26.5 & 29.6 & 23.9 & 27.9 & 26.9 & 30.6 & 28.0 & 21.0 & 24.7 & 29.1 \\
\hline $\begin{array}{l}\text { Non-core } \\
\text { constituency }\end{array}$ & 29.9 & 24.4 & 28.0 & 27.9 & 27.8 & 23.0 & 24.9 & 29.1 & 26.1 & 28.8 \\
\hline Non-labour force & 43.6 & 46.0 & 48.1 & 44.2 & 45.3 & 46.4 & 47.1 & 49.9 & 49.2 & 42.1 \\
\hline
\end{tabular}

Source: Eurobarometer Trend File 1970-2002 (ZA-Nr. 3521), own calculations.

Furthermore, critics may argue that the findings of this study merely reflect a continuation of the general trend towards the declining importance of class for vote choice, as anticipated by the scholars cited above. This is especially evident as the endeavour here is to investigate the expected dealignment of social democracy's core constituency. One might claim that the dealignment from social democracy merely reflects a secular and ubiquitous trend towards declining class voting, irrespective of social democracy's actual policies. Contrary to this claim, I argue that patterns of changing class voting are policy-induced when it comes to the alignment of social democracy's class constituency. Social democracy under the Third Way does not lose its core voters due to a secular trend. Rather, Third Way policy change, in the form of recommodifying welfare reforms, produces dealignments from social democracy. We can control for this by investigating the developments in a case where the social democrats did not adapt a Third Way agenda.

If I find diverging trends between countries with moderate reforms and countries with encompassing or even path-breaking reforms, the concern about a secular trend of declining class voting can be rejected. Moreover, the Third Way and welfare reforms under this ideological adaptation of social democracy may not only be a response to the suspected decrease in 
class voting, but also a further catalyst of this trend. If the reforms have an independent effect on the decline of social democratic voting among social democracy's core constituency, then the decline of class voting is not necessarily a rival explanation to the book's arguments, but rather a compatible perspective. Against this backdrop, my theoretical arguments and findings provide a more policy-based explanation for the suspected decline in class voting. In line with the partisan politics perspective, policy matters for the strength of class-based alignments to social democratic parties, and not just structural change, as typically emphasised in the literature on class voting. ${ }^{5}$ This book thus draws on micro-level data to investigate this electoral dilemma and its effect on class voting. The next chapter lays out the thesis's research design and methodology. 



\section{Design and Methods}

This chapter describes and discusses the design of the study, the data and the methods used for the empirical analysis in the following chapters. I begin with a delineation of the case selection strategy that allows me to test the propositions from Chapter 2. Following this, I describe the measures, concepts and data that are used to analyse the policy of the social democratic parties under review and the labour market reforms implemented in terms of the recommodification framework outlined in the previous chapter. Next, I present the statistical methods and the data sources applied to study the postulated electoral effects.

\subsection{Case selection and strategy of comparison}

The empirical analysis of the electoral consequences of Third Way welfare state reforms in the following chapters is based on a comparative analysis of four Western European countries. The rationale of the case selection is to choose cases that make it possible to test the propositions from Chapter 2 empirically. I apply theory testing case studies to examine causal claims (George \& Bennett 2005: 75), and the recommended intentional selection is based on the research objective and strategy (King et al. 1994: 139f). More concretely, selecting typical cases on the variables of interest is the suggested method for this type of study (Gerring 2007: 91ff).

The case selection comprised three stages. First, I had to choose a country in which a large social democratic party did not undergo an encompassing Third Way transformation during the 1990s, unlike many other social democratic parties at the time. This was the case in Sweden, where the reforms were more moderate and often temporary (e.g. Lindbom 2001). ${ }^{1}$ Sweden is used as a 'control case' where the key explanatory concept - the welfare state reforms under Third Way agendas - takes a different value (King et al. 1994: 20off); that is, the reforms are more moderate and do not represent an outright break with existing policy principles. 
Another reason is that Swedish social democracy has always advocated active labour market policies and did not have to introduce these policies in a way that conflicted with previous policy principles. The choice of Sweden also controls for the decline of class voting as a general explanation for the electoral decline of social democracy. Due to the existence of an established left-wing challenger (Vänsterpartiet) at the beginning of the period of investigation (1991), the choice of Sweden also controls for whether challengers gain strength irrespective of social democratic policy choices. Accordingly, the case of Sweden is analysed in the final empirical chapter to compare the electoral effects in countries with Third Way social democracies with those in a country where no explicit transformation took place.

Second, to study the proposed effect of the electoral system, I had to choose a country where a social democratic party had adopted a Third Way agenda and implemented path-breaking reforms in office under an FPT P system. This constellation can be found in the United Kingdom, with the transformation of the Labour Party as the prototype of Third Way social democracy under a single-member constituency electoral system. The United Kingdom was thus chosen as a typical case (Gerring 2007) of an FPTP system, given the theoretical proposition on the role of electoral systems for the electoral consequences of the reforms.

Third, Denmark and Germany were chosen as cases where social democracy faced competitor parties of theoretical relevance under PR systems, as argued before. In both countries, social democratic parties faced leftsocialist parties (the Party of Democratic Socialism, PDS) and later the Linkspartei (Left Party) in Germany, and the Socialistisk Folkeparti in Denmark after their ideological realignment and implementation of pathbreaking welfare state reforms. However, the respective chapters will show that the two leftist competitors adopted different political strategies. This feature allows me to investigate the respective arguments on the credibility of challenger parties. In contrast to the German Left Party, the Danish socialists were part of a legislative coalition with the social democrats. The expectation is therefore that the party would fail to forge a realignment, in contrast to its German equivalent, which was a pure opposition party when reforms were implemented.

The Danish social democrats also face a right-wing challenger, the Dansk Folkeparti, which fits the above description of this type of party quite well. This case allows us to test the proposition regarding the success of right-wing parties. In Germany, the social democratic party (SPD) is also challenged by an established mainstream Christian democratic 
party, which has also traditionally had a welfare reputation (van Kersbergen 1995). The SPD, however, did not face a serious challenger from the far right, despite the PR system. As argued in Chapter 2, the German People's Union (DVU) and the National Democratic Party (NPD) represent extremist anti-system parties and not parties of the new right. Thus, in the empirical analysis in Chapter 5 , the German case is treated as having no competitive challenger from the right. In sum, the two countries are typical cases, as they have PR systems and their party systems contain the parties identified as the most dangerous challengers to reform-minded social democrats. They also allow us to test the argument on the credibility of challengers.

On the other hand, the countries vary considerably on other aspects that are often emphasised in the welfare state literature, especially the literature on welfare state retrenchment. Beginning with Esping-Andersen's classic welfare state typology (1990), I have drawn cases from each of the three clusters: the United Kingdom belongs to the liberal type of welfare state, Denmark and Sweden to the social democratic type, and Germany represents the archetypal Christian democratic welfare state. Although this distinction has sometimes been used to predict the likelihood of welfare state reforms with the institutional logic of the welfare regime (examples are Esping-Andersen 1990; Bonoli 2001; Huber \& Stephens 2001; Korpi \& Palme 2003), I do not regard this as a determinant for the electoral consequences. The reason is that we find similar reforms in three different welfare regimes, as the case studies of Denmark, Germany and the United Kingdom will show, and the social democratic parties show sufficient similarity in the type of policies they have traditionally advocated, as the review of their programmatic and social policy records will reveal. ${ }^{2}$ They were also tied to similar voter groups as core constituencies, although with some variation. For instance, the Labour Party was not as successful as the Swedish SAP in attracting lower white-collar employees. Nonetheless, irrespective of the type of the welfare regime in which the parties act, the respective electorate can be expected to have sufficiently similar expectations of the country's social democratic party.

Other variations concern the political system and institutions, as the four countries differ substantially. The uK has the archetypal Westminster system, with few veto players given the single-party government rule, the unitary state structure and the dominant position of the lower house. The two Scandinavian countries have multi-party (often minority) governments and a unitary state structure with a unicameral parliamentary system, but corporatist structures. Finally, Germany has a variety of veto 
players due to its bicameralism with a federal state structure, which often leads to a divided government. Germany is also characterised by majority coalition governments, juridical review and a strong corporatist tradition. Although these features are often used to explain the capacity to reform and retrench the welfare state (cf. the reviews of Green-Pedersen \& Haverland 2002; van Kersbergen 2002; Starke 2006; see also the composition of different arguments in Starke 2008: chap. 2), they offer no peculiar arguments on the electoral consequences of the reforms, but reflect variation that does not directly conflict with the theoretical propositions.

Another aspect is that the countries' features that I identified as theoretically relevant cannot always be disentangled from the other properties emphasised by the literature, but remain mutually supportive. For instance, a Westminster-style political system with a majoritarian electoral system typically goes hand in hand with a liberal welfare state (Iversen 2005: chap. 4; Manow 2007). Countries with PR systems typically belong to the social democratic or Continental European welfare state cluster. Other theoretically possible combinations do not exist in reality. ${ }^{3}$

While these caveats should be kept in mind, I argue that the other sources of variation do not influence the empirical results as they basically point to the conditions for reforms, but not to the actual consequences of those reforms, once implemented. Rather, understood in the logic of diverse cases, comparative case studies face the challenge of 'variation and representativeness' (Gerring 2007: chap. 5). The case selection thus reflects the variation on the crucial features mentioned in Chapter 2 that are necessary to test the arguments. The variation is theoretically motivated and rests on these crucial and distinctive features. Accordingly, the case selection includes a country with less encompassing reforms, the two types of electoral systems (FPTP and PR), and countries with party systems that include those parties that I characterise as the most dangerous challengers to reform-minded social democrats. This is illustrated in Table 3.1.

Table 3.1 Electoral system, party competition and possible contenders for reformminded social democrats in the early $1990 \mathrm{~s}$

\begin{tabular}{llll}
\hline & \multicolumn{2}{c}{ FPTP } & PR \\
Reforms & Competitors marginalised & Left challenger & Right challenger \\
\hline No & Non-existent & Sweden & - \\
Yes & United Kingdom & Germany, (Denmark) & Denmark \\
\hline
\end{tabular}

Source: Own compilation. Parentheses indicate non-credible challenger. 
In the period of investigation, many European social democratic parties underwent a transformation under Third Way agendas and regained office in the early to mid-1990s, until they were voted out of office during the first decade of the millennium. This was the period in which the Third Way materialised in terms of actual policies, and not only as an academic construct. As we saw in Section 2.3, after having replaced centre-right governments, social democrats implemented labour market reforms that contradicted traditional social policy principles. In other words, choosing the period in which social democrats held office allows us to study the electoral effects when the actual policy change came into play. As a point of reference, I also use the last election before the Third Way agenda, as well as the first election after the parties lost office or partly left the Third Way. This yields the following periods for the four countries: Denmark (1990-2005), Germany (1994-2009), Sweden (1991-2006) and the United Kingdom (1992-2010). The periods cover time spans of 15 to 18 years and at least four elections in each country.

\subsection{Analysis of reforms}

Each chapter begins with a brief description of the ideological stance and political objectives of the four social democratic parties and a summary of their policy record prior to the 1990s, to illustrate that they did indeed reflect the decommodification principle in ideology as well as policy. Afterwards, I characterise the transformation of the three parties that adopted Third Way agendas and the more orthodox programmatic appeal of Swedish social democracy.

Subsequently, I analyse the policies and reforms implemented in the countries from both a qualitative and a quantitative perspective. This twopronged approach bridges the gap between the two schools of thought in the literature on welfare state change (cf. Green-Pedersen 2004; Clasen \& Siegel 2007; Starke 2008: chap. 2). This provides a more comprehensive picture, in view of the fact that both approaches have deficiencies and virtues, as discussed in the literature on the 'dependent variable problem' for the study of welfare state change (Green-Pedersen 2004; Clasen \& Siegel 2007).

Given the key theoretical claim that recommodification is the cause of social democratic decline, recent advances in the literature have developed concepts and measures that come very close to Esping-Andersen's conceptualisation and thus allow an elaborated operationalisation. Starke (2008: 19) classifies as retrenchment those policy changes that lead to: 
1) reductions in benefit levels and duration,

2) tightening of eligibility, and

3) restrictions in benefit coverage.

This matches the measures that - based on Esping-Andersen $(1985,1990)$ - are classified as recommodification and contain a qualitative as well as a quantitative element. Beginning with the qualitative aspects, Clasen \& Clegg (2007) developed a conditionality framework to study qualitative changes over time, which elaborates on the concept of commodification. In short, the rationale behind this framework is whether legislative changes introduce/strengthen or abolish/diminish the conditions attached to drawing unemployment benefits. This can be applied as a qualitative measure for recommodification that captures changes in the universality of social insurance, eligibility criteria and entitlements by describing and classifying legislative changes of unemployment support. The classification rests on three levels and levers of conditionality, as it incorporates conditions of membership (universality of benefits), conditions of circumstance (e.g. eligibility criteria and requirements) and conditions of conduct (behaviour). I define the legislative changes in conditionality (i.e. reforms) in Clasen \& Clegg's framework as recommodification in a qualitative sense that is, or can be, classified as tighter or more intensive conditionality, respectively.

Fortunately, Clasen \& Clegg's empirical work (2007; Clasen 2005) already covers labour market reforms in three of the four countries quite extensively, as major legislative changes concerning unemployment support in Denmark, Germany and the United Kingdom are classified for the period between 1979 and 2005. I will supplement the empirical findings with my own literature review for the three countries. In the case of Sweden, I make an analogous compilation of the legislative changes that uses the same practices to classify the labour market policies by reviewing the literature.

Turning to the quantitative operationalisation of recommodification, I draw on the widely used replacement rates as indicators of welfare state generosity developed and applied by Scruggs $(2006,2007)$ and the OECD (2010a and various years for other sources). The data allows me to quantify welfare state entitlements and changes to these over time in terms of the commodification approach applied in the present study, as they measure 'the portion of income replaced by a social welfare programme' (Scruggs 2007: 143). The data sources thus allow me to study income replacement over time, which is a crucial component of decommodification 
in Esping-Andersen's work; he used similar indices with data that were not publicly available $(1985,1990) .{ }^{4}$ Recommodification in a quantitative sense is thus understood as lower replacement rates as a consequence of labour market reforms.

The reason for using two data sources is twofold. First, using two indicators of income replacement that apply slightly different methods to calculate the figures increases the validity of the conclusions. Investigating whether recommodification in a quantitative sense took place due to the reforms implies taking a more conservative approach. One will be more cautious if one data source shows somewhat extreme developments, whereas the other data source does not indicate a similar development. A second and more pragmatic reason is that not all years for each country are covered by the same data set, meaning that one has to draw on a second data source. For instance, Scruggs' data (2006) does not cover the labour market reforms in Germany between 2003 and 2005, as the data series ends with 2003. By contrast, using OECD summary data (2010a) allows me to investigate the effect of the reforms on replacement rates and thus the generosity of social security over the years, but the reports on 'Benefits and Wages' do not cover the reforms of the mid-199os.

The unemployment replacement rates obtained from Lyle Scruggs' 'Welfare State Entitlements Dataset' Project (2006) include the degree of income replacement for 18 Western countries over the period 1971-2002 (or even longer). The data include information on benefit replacement rates, qualifying conditions, coverage and take-up ratios obtained from various national and international sources. A comprehensive description of the data including codebooks and operationalisation procedures can be found in Scruggs (2006, 2007).

The OECD has developed a 'Summary Measure of Benefit Entitlements' that is 'defined as the average of the gross unemployment benefit replacement rates for two earnings levels, three family situations and three durations of unemployment' (2010a). ${ }^{5}$ It thus contains measures for gross replacement rates over the period 1961-2007 for uneven years and allows me to investigate the effect of labour market reforms on the degree of income replacement in the case of unemployment in general. When necessary, this is supported by using specific information and replacement rates for particular unemployment situations from the OECD's series 'Benefits and Wages' that started in $1998 .{ }^{6}$

In sum, by applying elaborate measures and concepts on both the qualitative and the quantitative aspects of labour market reforms, my operation- 
alisation of (re)commodification comes very close to Esping-Andersen's theoretical conceptions $(1985,1990)$.

\subsection{Analysis of the electoral consequences of reforms}

The electoral consequences of the reforms will be analysed in two steps. First, a descriptive part looks at attitudes towards welfare policy, welfare state reforms and policy changes among the social democratic core constituency and the remaining voters. I also present the vote shares of the theoretically important parties among the different voter groups to give a first general indication of patterns of electoral change during the period of reforms, looking in particular at whether social democracy's vote share among the core constituency declined during the Third Way period (or 1991-2006, in the Swedish case).

The statistical part examines whether attitudes towards labour market reforms, welfare policies and policy changes had electoral consequences, and which types of electoral consequences, in terms of the theoretical expectations. The technique used is that of multinomial logistic regression models, which is well suited to and widely used in the study of voting behaviour, as party choice is typically a categorical dependent variable (e.g. Long \& Freese 2006).

The independent variables in the logistic regression models consist of at least two measures: the respondents' voter group and a variable that captures attitudes towards the reforms that will be described in more detail in the country chapters. Other variables will be described in the country chapters as well. The voter group variable distinguishes between non-core constituency, non-aligned core constituency and aligned core constituency. Aligned core constituency means belonging to the social democratic core constituency as defined above and having voted for the social democratic party before, operationalised via the respective vote recall questions in the data sets. I use confirmative analyses for elections after a major electoral change to check that these changes were not reversed in the following election. This is done by adding a category for the voter group variable that captures voters from the social democratic core constituency who have chosen the option that I theoretically expect as a consequence of the reforms. For instance, in the British case, I first investigate whether Labour core voters abstained in 2001 as a consequence of their disaffection with Labour's policy change. Afterwards, I investigate whether non-voters from the core constituency (captured by this addi- 
tional category) had a tendency to return to the Labour Party in the 2005 general election. Given the lack of applicable and available panel data sets for all cases under review, this at least controls for lasting effects in a probabilistic sense, as a large outflow of social democratic core voters as an effect of reforms at $\mathrm{T}_{1}$ that is not followed by a considerable backflow to the social democrats at $\mathrm{T} 2$ gives a clear pattern of lasting electoral consequences. Similarly, this controls for lasting gains for challenger parties among the social democratic core constituency or an increased tendency for these voters to abstain in an FPTP electoral system. Together with the descriptive results on party shares during the Third Way period, this should yield some pretty robust results. In this vein, both one-shot effects and longer lasting changes to party affiliations can be identified, given the absence of panel data.

In the logistic regression models, I only included the main effects for the dummy variables and did not introduce any interaction effects, given the ongoing discussion on the proper application and interpretation of interaction effects in logistic regression models (Ai \& Norton 2003; Norton et al. 2004; Berry et al. 2010). The core argument made by Berry and collaborators is that statistically significant interaction terms are neither necessary nor sufficient for the interaction term to have a meaningful effect on the values of the dependent variable. Given the nature of the logit function, even the significance level and the sign of an interaction may yield misleading results that are difficult to interpret in a meaningful manner. Rather, I followed the authors' recommendation to model the effects with conditional probabilities using the Clarify programme (King et al. 2000; Tomz et al. 2003). This is especially feasible given the dummy coding of each variable that makes it possible to model the presence and absence of one or more conditions, as well their interaction, without including a product term. The results are presented as conditional probabilities and not as regression coefficients. ${ }^{7}$ Moreover, Clarify presents confidence intervals for the predicted probabilities, which makes it possible to identify significant differences between party shares under given conditions. For instance, does the share of social democratic voters in the group of reform-minded voters differ significantly from its share among the reform-averse voters? The tables in the country chapters present the effects of social policy attitudes on the probabilities of voting for a particular party, shifting to another party or abstaining in the different voter groups. ${ }^{8}$ 


\subsection{Data sources for the statistical analysis}

The data sources are only briefly introduced and described here, as I explain the variables in detail in the country chapters. I use national election studies and exit polls for the British, Danish and Swedish cases and the Politbarometer surveys for the German case. The respective national election studies comprise the Danish National Election Studies for elections to the Folketing 1990-2005, the Swedish Election Studies and exit polls for Riksdag elections 1991-2006, and the British General Election Studies (BES) for Westminster elections 1992-2010. In the German case, I decided not to use the German National Election Studies (DNws) for the logit models, as the Politbarometer data sets after 2004 contain items that directly ask respondents about their attitudes towards the reforms after 2002, which are not available in the DNws. However, the Politbarometer Studies, which are conducted by the German Institute for Election Research (Forschungsgruppe Wahlen), have often been used by electoral research as an alternative to the DNWs. Given the superior information in the data sets, I draw on Politbarometer surveys for most of the statistical analysis in the German case.

\subsection{Organisation of chapters}

The chapters are organised in accordance with the methodological approach outlined above. Each chapter starts with a brief introduction to the political situation in the relevant country and the initial situation of the country's social democratic party. I then review the party's programme and social policy record, on which its ties with its core constituencies were based. I then analyse the reforms using the qualitative and quantitative measures described above, and place them in the national political context. This is followed by a discussion of the electoral system, party competition and possible competitor parties to spell out the hypotheses for the individual chapters. After a description of the variables and items used, I analyse the electoral effects of the reforms by means of descriptive and statistical analysis. The last section sums up the findings and discusses implications and developments in the national context. Figure 3.1 summarises the relevant features of the countries' party systems and the hypothesised developments. The background for the formulation of the hypotheses will be further elaborated in the case study chapters, in which the behaviour of the political parties is discussed. 


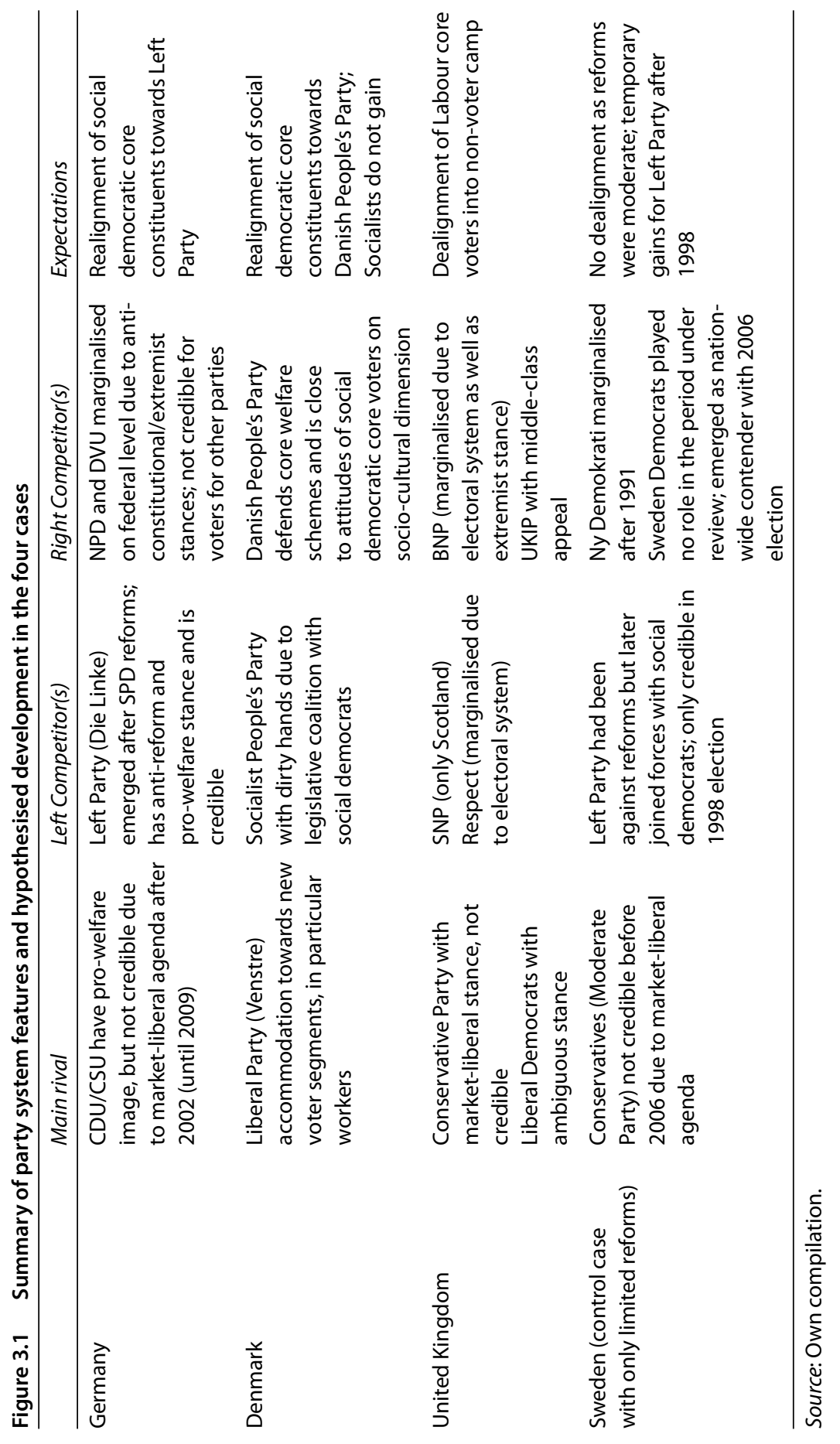





\section{$4 \quad$ United Kingdom}

This chapter examines the proposition that an FPTP electoral system only produces a non-voter trade-off for Third Way social democrats, as it effectively constrains the electoral fortunes of those challengers that have been identified as dangerous in the theoretical framework. The United Kingdom is used as a typical case on the basis that the Labour Party should face different opportunities and constraints to engage in welfare state reforms compared to its continental sister parties, thanks to the British single-member plurality electoral system (e.g. Kitschelt 2001a; Randall \& Sloam 2009). In this respect, Randall \& Sloam (2009) have claimed that the adoption of Third Way agendas by social democratic parties and the political reforms under these agendas imply higher political costs for continental social democratic parties than for Labour. The same holds true for the electoral aftermath of those reforms, as the corresponding electoral dilemmas for the Labour Party should have a distinct character, as discussed in Chapter 2.

The Labour Party's transformation in the 1990 s is often seen as the prototype of Third Way social democracy. In 1997, after 18 years in opposition, the Labour Party returned to power having undergone a process of ideological transformation, as indicated by the label 'New Labour'. In office, the party's changed ideological position on social and economic policy became visible as New Labour implemented the 'New Deal' welfare state reforms, indicating a policy change from Labour's old social policy legacy (e.g. Shaw 2003, 2007; Clasen 2005).

On the other hand, Labour's only challengers were the existing competitors on the national level, the Conservatives and the Liberal Democrats. Neither did a serious challenger on the margins emerge after 1997. The most striking development was a decline in turnout of more than 10 percentage points under the aegis of Tony Blair, which fits the hypothesised effect of FPTP electoral systems for the electoral consequences of Third Way reforms. This chapter investigates the proposed effect of the unique electoral system; that is, an expected dealignment of Labour core voters into the non-voter camp. 


\subsection{The social policy of the Labour Party}

With respect to social policy commitments, Labour does not have a party constitution comparable to those of the German SPD or the Swedish SAP (Shaw 2007: 18). Rather, the Beveridge report published in 1942 and the writings of Crosland (1956), Marshall (1950), Tawney (1964) and Titmuss (1958) provided the basis of Labour's post-war social policy commitments. In terms of the party's ideology, Shaw $(2003,2007)$ has characterised Labour's traditional programmatic stance on the welfare state as representing core social democratic values in line with Esping-Andersen's (and Huo's) thoughts outlined above. Labour's ideology reflected income maintenance through entitlements, full employment, egalitarianism, solidarity and, most importantly, the decommodification of labour through social rights (Shaw 2003: $7 \mathrm{ff}, 2007$ : chap. 1). Moreover, collectivism and egalitarianism had been identified as Labour's traditional policy aspirations, and the party had been ideologically committed to a universal welfare state (see also Ellison 1997). This was reflected in Labour's social policy record in the second half of the 2 oth century, before the party transformed its image as New Labour.

Labour's actual policy record closely reflects the party's social policy aspirations. The 1945-1951 Labour government introduced the National Health Service (NHS), a major social policy innovation in the history of the British welfare state (Hill 1993: 31ff; Glennerster 2007: chap. 3). Labour also reformed the National Insurance system, indicating higher levels of benefits for various social groups. After Labour lost the general election in 1951, the party went into opposition for 13 years. Before, the party had criticised its conservative opponent for its stance on welfare and tried to mobilise voters on expected cuts in welfare services and social spending. However, between 1951 and 1964, the Conservative governments had some achievements in welfare policy, which were also ascribed to electoral considerations (Hill 1993: 61f; Glennerster 2007: 95).

In order to return to power in 1964, Labour brought forward an ambitious electoral manifesto in terms of welfare state expansion (Glennerster 2007: 97ff). Labour promised to increase social security benefit levels, especially income maintenance in case of unemployment or sickness. A reconstruction of the social security system was proposed that would turn means-tested schemes into a contribution-based income replacement scheme. Pensions would no longer only be based on the flat-rate Beveridge scheme, but extended with a wage-related 
supplement. In reality, the Wilson government increased the social security benefits for unemployment, health and pensions, although some critics regarded the expansion of social security as insufficient given Labour's ambition for a more comprehensive expansion of the British welfare state (cf. Hill 1993: chap 5; Glennerster 2007: chap. 5). Labour also introduced income replacement schemes in case of unemployment and sickness, but only with a temporary eligibility period. Somewhat surprisingly, Labour lost the general election in 1970, and Edward Heath's Conservative government lasted until 1974. The Heath government's record on social policy is mixed. The period was characterised by social policy expenditure and extended use of means-tests (see Hill 1993: chap. 6).

In 1974, Labour returned to power. The government introduced some major social security measures until 1976, when the premiership changed from Harold Wilson to James Callaghan and Britain's economic situation started to deteriorate (cf. Glennerster 2007: 122). Most importantly, Labour implemented the State Earnings-Related Pension Scheme (SERPS), a new pension scheme intended to guarantee replacement rates up to 100 per cent in the long run, but that also included non-labour market participants such as people bringing up children and carers (Glennerster 2007: 114f).

The economic crisis in 1976 marked a watershed for both British social policy and the Labour Party (Hill 1993: 122; Ellison 1997: 45; Glennerster 2007: 168ff). The party had to bring public spending under control and introduce cuts. Labour lost the general election in 1979 and remained in opposition until 1997, a period during which the party fiercely criticised the Conservative governments' social policy (Heffernan 2001: 21, 70). Until 1992, when Labour was increasingly changing its programme, including its commitment to the welfare state to regain power, Labour's post-1979 stance on economic and social issues had been characterised as predominantly in line with the party's basic principles (Heffernan 2001: 69).

Summing up, the Labour Party's social policy record is in line with Esping-Andersen's framework on social democratic policies, even though one has to take into account the particular character of the British welfare state. The same is true for Labour's ideological commitment to traditional social democratic goals. Thus, we should expect particular classes to be aligned to Labour as its core constituency. 


\subsection{Alignment of the social democratic core constituency in the United Kingdom}

Table 4.1 shows the major parties' vote shares among selected social classes. The figures reveal that between 1964 and 1997, Labour attracted the working class as its core constituency. Lower white-collar employees did not align with Labour to the same degree, but constituted the class outside the working class in which Labour performed best over time (cf. Evans \& Norris 1999: 90). ${ }^{1}$

The support of the working class has been highly stable over time. However, in the period under review, support for Labour was lowest among workers, as well as among the electorate in general, during the two elections in the 1980s. This had been attributed to the emergence of the Social Democratic Party (SDP) in the 1980s, which formed an electoral alliance with the Liberal Party in 1983 and 1987. Being a splinter of the Labour Party, the SDP was able to attract parts of Labour's voter base given Labour's distinct left-wing stance on socio-cultural issues and its perceived incompetence (Heath et al. 2001: chap. 5). ${ }^{2}$ After Labour's abandonment of this stance in the 1980s, the party's new leadership and the SDP's merger with the Liberal Party, Labour was able to recapture these voters in the 1990 os. Labour thus represents the classic working-class-based social democratic party in the British post-war era (e.g. Butler \& Stokes 1974). This is supplemented with a sizable backing among lower white-collar workers.

Table 4.1 Party choice by selected social classes, United Kingdom 1964-1997

\begin{tabular}{llrrrrrrrrrr}
\hline & & 1964 & 1966 & 1970 & $\begin{array}{l}1974 \\
\text { Feb. }\end{array}$ & $\begin{array}{l}1974 \\
\text { Oct. }\end{array}$ & 1979 & 1983 & 1987 & 1992 & 1997 \\
\hline Labour & RNM & 26 & 41 & 40 & 29 & 32 & 32 & 20 & 26 & 30 & 49 \\
& Skilled & 70 & 73 & 63 & 59 & 62 & 58 & 47 & 48 & 50 & 67 \\
& Unskilled & 66 & 70 & 61 & 61 & 65 & 53 & 49 & 48 & 60 & 69 \\
Cons. & RNM & 59 & 49 & 51 & 45 & 44 & 52 & 53 & 51 & 54 & 33 \\
& Skilled & 25 & 22 & 33 & 23 & 20 & 28 & 33 & 31 & 37 & 14 \\
& Unskilled & 26 & 25 & 32 & 24 & 22 & 34 & 29 & 31 & 28 & 18 \\
Liberals & RNM & 15 & 10 & 9 & 26 & 24 & 16 & 27 & 23 & 16 & 18 \\
& Skilled & 5 & 5 & 4 & 18 & 18 & 14 & 20 & 21 & 13 & 19 \\
& Unskilled & 8 & 5 & 7 & 15 & 13 & 13 & 22 & 21 & 12 & 13 \\
\hline
\end{tabular}

Source: Evans et al. (1999: 90, Table 5.1), drawing on British Election Studies data.

Notes: RNM: Routine non-manual employees. Skilled: skilled workers; Unskilled: unskilled workers. Liberals: 1964-79: Liberal Party; 1983-87: Alliance of SDP and Liberal Party; after 1990: Liberal Democrats. 
Table 4.2 gives an overview of the vote shares of the three major parties and turnout in Britain in the last four decades. What is striking, in terms of the purposes of this chapter, is the drop in turnout after 1997 (cf. also Denver \& Fisher 2009). Before the 2001 election, turnout remained in a rather narrow interval between approximately 72 and 78 per cent. After New Labour's first term it dropped below 60 per cent and did not recover in the following election. This gives a first impression of the proposed effect that there is a dealignment of core voters in an FPTP system after social democrats undergo a Third Way transformation.

Table 4.2 Vote shares for three major parties and turnout in British general elections, 1964-2005

\begin{tabular}{lrrrrrrrrrrrr}
\hline & 1964 & 1966 & 1970 & $\begin{array}{l}1974 \\
\text { Feb. }\end{array}$ & $\begin{array}{l}1974 \\
\text { Oct. }\end{array}$ & 1979 & 1983 & 1987 & 1992 & 1997 & 2001 & 2005 \\
\hline Labour & 44.1 & 47.9 & 43.0 & 37.1 & 39.2 & 37.0 & 27.6 & 30.8 & 34.4 & 43.3 & 40.7 & 35.2 \\
Cons. & 43.3 & 41.9 & 46.4 & 37.8 & 35.8 & 43.9 & 42.4 & 42.3 & 41.9 & 30.7 & 31.7 & 32.4 \\
Liberals & 11.2 & 8.5 & 7.5 & 19.3 & 18.3 & 13.8 & 25.4 & 22.6 & 17.8 & 16.8 & 18.3 & 22.0 \\
Turnout & 77.1 & 75.8 & 72.0 & 78.1 & 72.8 & 76.0 & 72.7 & 75.3 & 77.7 & 71.5 & 59.4 & 60.9 \\
\hline
\end{tabular}

Source: Butler \& Kavanagh (2002: 261f); Norris \& Wlezien (2005). Notes: Liberals: 1964-79: Liberal Party; 1983-87: Alliance of SDP and Liberal Party; 1990-2005: Liberal Democrats.

Looking back at Table 4.1, we can observe that Blair's victory in 1997 rested on a strong mobilisation of Labour's core constituency, comparable to the results in the pre-Thatcher elections. After New Labour's changed ideological commitment to the welfare state became visible in daily politics (see below), the party lost votes in the 2001 and 2005 elections. However, only the Liberal Democrats recovered to the levels seen in the 1980s. As demonstrated in Table 4.2, turnout in Britain significantly declined under New Labour, perhaps due to a dealignment of Labour's rank and file. The next step is to investigate the welfare state reforms under New Labour and discuss the role of party competition during the period under review.

\subsection{Welfare state reforms in Britain under New Labour, 1997-2005}

Before I turn to the analysis of the labour market reforms under New Labour, some introductory remarks on the character of British unemployment insurance have to be made. The traditional British system of unemployment insurance and benefits was not predominantly contribution-based, as was 
common in most other European countries, but mainly financed through taxes (Clasen 2005). However, unemployment insurance was partly co-financed by National Insurance. The benefits were a combination of flat-rate and earnings-related benefits. The contribution requirements to claim unemployment benefits were very lenient and activation was also very weak (Clasen 2005: 57ff). Before 1979, after which the system was reformed by both Tory and Labour governments, unemployment insurance had a low degree of conditionality. The traditional unemployment system was thus a hybrid of a needs-based tax-financed system and a contribution-based insurance system, predominantly administrated by the state and not by corporatist arrangements, as was common in Continental Europe.

Having won the elections in 1997, the Labour Party started to implement the 'New Deal' programme aimed at reforming the labour market. The programme was generally characterised as a clear break with Labour's social policy commitments in the post-war era, since it represented a 'welfare to work' strategy with mandatory shifts from welfare benefits to labour market programmes (e.g. Hewitt 2002; Annesley \& Gamble 2004; Clasen 2005: 81f; Rueda 2007: 174ff; Merkel et al. 2008: 49ff). It left the somewhat far-reaching reforms of the previous conservative government in place; for instance, it did not reintroduce the Bismarckian status-maintaining elements of the former unemployment insurance legislation that had been abolished by the previous Conservative government. New Labour also kept the Job Seekers Allowance (JSA) legislation of the Major government as a foundation for the New Deal reforms to come. Moreover, Clasen (2005: 83) states that the policy reorientations 'highlight Labour's acceptance of the need for a flexible and deregulated labour market, and its strategy aimed at integration into employment which might be low paid and thus requires public subsidy'.

The New Deal programme changed the British system of unemployment insurance: welfare entitlements were no longer granted by welfare rights but by principles of conditionality, as already foreseeable under the Conservative government (e.g. Hewitt 2002; Dwyer 2004; Taylor-Gooby et al. 2004; Clasen 2005: chap. 4; Shaw 2007: 145f). The measures launched sanctions on the unemployed who refused to participate in labour market programmes, including job-search assistance and training. The eligibility periods for benefits were linked to participation in the new programmes and work-related conditions were enforced (Hewitt 2002; Dwyer 2004: $27 \mathrm{off}$ ). In contrast to its traditional universalistic stance, Labour imposed compulsory labour market programmes, particularly for groups such as the long-term unemployed and jobless young people. Labour left the re- 
forms of the previous Conservative government largely in place, as demonstrated by Clasen (2005) and Clasen \& Clegg (2007). Table 4.3 gives an overview of the important labour market reforms implemented under Conservative and Labour governments during the last three decades.

New Labour also changed the administration of the unemployment system; in particular, the placement of job seekers became more clientbased. The New Deal programme implemented the use of market mechanisms to achieve welfare aims (Taylor-Gooby et al. 2004) by developing tax credit schemes and other measures to create employability by rewarding people for taking up precarious work.

To express the changes in quantitative terms, that is, replacement rates, Tables 4.4 and 4.5 show the development of benefit entitlements over time. The OECD summary measure presented in Table 4.4 reveals that Labour even reduced the low replacement rates inherited from previous Conservative governments from 17 to 12 per cent in 2007. The post-reform figures mark the lowest values in the OECD time series beginning in 1961. The figures for net replacement rates for long-term unemployed in Table 4.4 should be interpreted with some caution, as the OECD changed the definition of this measure between 1997 and 2001. Nevertheless, there is some evidence that this type of income maintenance declined after New Labour came into office in 1997 and that there has since been no increase.

In sum, New Labour did engage in policy change, since the reforms reveal a clear pattern of increased conditionality and recommodification (Hewitt 2002; Rueda 2007: 208ff; Clasen \& Clegg 2007; Shaw 2007: 145). New Labour did not always actively engage in legislation, but simply preserved the labour market policy inherited from the Thatcher and Major governments to a considerable degree. This was especially the case for the tightened benefit eligibility and entitlement criteria implemented under the Tories (Clasen \& Clegg 2007: 177). Labour adapted to its Conservative opponent by abandoning its original decommodification stance (cf. Heffernan 2001 on Labour's convergence towards the Conservatives' social and economic policy) and emphasising recommodification, as the results in Tables 4.3 and 4.4 show. Labour's changed commitment to the welfare state and the main features of the reforms clearly contradict EspingAndersen's call for unconditional, permanent and generous benefits to secure decommodification $(1985,1990: 47 \mathrm{ff})$ and, thus, social democratic mobilisation. New Labour's policy change has been characterised as an accommodation to the market that reflects a significant departure from social democratic tradition (Shaw 2007; Randall \& Sloam 2009: 106). These reforms imply that Labour risked alienating its social democratic 
core voters, as discussed in Chapter 2 (cf. also Cressey 1999: 190). However, we would expect the actual electoral effects to be conditioned by the electoral system and party competition, to which we now turn.

Table 4.3 Selected labour market reforms introduced by Conservative and Labour governments, 1998-2005

\begin{tabular}{|c|c|c|c|}
\hline Year and legislation & Reform (status quo in brackets) & $\begin{array}{l}\text { Level of con- } \\
\text { ditionality }\end{array}$ & $\begin{array}{l}\text { Direc- } \\
\text { tion }\end{array}$ \\
\hline & \multicolumn{3}{|c|}{ Conservative governments $1979-97$ (selected reforms) } \\
\hline 1982: Abolition of ERS & $\begin{array}{l}\text { Earnings related supplement (ERS) to } \\
\text { unemployment benefits (UB) abolished }\end{array}$ & Eligibility & $\mathrm{R}$ \\
\hline $\begin{array}{l}\text { 1986-92: various } \\
\text { reforms }\end{array}$ & $\begin{array}{l}\text { Tightening of disqualification conditions for } \\
\text { unemployment benefits }\end{array}$ & $\begin{array}{l}\text { Behaviour/ } \\
\text { Conduct }\end{array}$ & $\mathrm{R}$ \\
\hline 1988 & $\begin{array}{l}\text { Tighter contribution record required for } \\
\text { unemployment benefits }\end{array}$ & Eligibility & $\mathrm{R}$ \\
\hline $\begin{array}{l}\text { 1996: Introduction of } \\
\text { Job seekers Allowance }\end{array}$ & $\begin{array}{l}\text { Maximum duration period of contributory JSA } \\
\text { reduced from } 12 \text { to } 6 \text { months }\end{array}$ & Eligibility & $\mathrm{R}$ \\
\hline $\begin{array}{l}\text { (JSA) consisting of } \\
\text { contributory JSA and }\end{array}$ & $\begin{array}{l}\text { Reduction of benefit rates for JSA claimants } \\
\text { aged } 18 \text { to } 24 \text { by } 20 \%\end{array}$ & Eligibility & $\mathrm{R}$ \\
\hline \multirow[t]{3}{*}{ income-related JSA } & $\begin{array}{l}\text { Remaining dependent additions existing under } \\
\text { UB withdrawn }\end{array}$ & Eligibility & $\mathrm{R}$ \\
\hline & $\begin{array}{l}\text { Introduction of requirement to sign job seeker's } \\
\text { agreement; includes obligatory directions }\end{array}$ & $\begin{array}{l}\text { Behaviour/ } \\
\text { Conduct }\end{array}$ & $\mathrm{R}$ \\
\hline & Labour governments 1997-2005 & & \\
\hline $\begin{array}{l}\text { 1998: New Deal for } \\
\text { young people (NDYP) } \\
\text { \& long-term } \\
\text { unemployed (NDLTU) }\end{array}$ & $\begin{array}{l}\text { Increased conditionality for benefit receipt, } \\
\text { mandatory participation in New Deal } \\
\text { programme (more moderate rules before with } \\
\text { non-mandatory programmes) }\end{array}$ & $\begin{array}{l}\text { Behaviour/ } \\
\text { Conduct }\end{array}$ & $\mathrm{R}$ \\
\hline 1999: New Deal for & Joint claim for those with partners claiming & Behaviour/ & $\mathrm{R}$ \\
\hline partners (NDP) & $\begin{array}{l}\text { job-seekers allowance (no joint claim to qualify } \\
\text { for benefits) }\end{array}$ & $\begin{array}{l}\text { Conduct } \\
\text { Membership }\end{array}$ & $\mathrm{D}$ \\
\hline 2001: New Deal 25+ & $\begin{array}{l}\text { Mandatory participation in labour market } \\
\text { schemes if unemployed for } 18 \text { of the last } 21 \\
\text { months (more moderate rules before with non- } \\
\text { mandatory programmes) }\end{array}$ & $\begin{array}{l}\text { Behaviour/ } \\
\text { Conduct }\end{array}$ & $\mathrm{R}$ \\
\hline $\begin{array}{l}\text { New Deal for disabled } \\
\text { people }\end{array}$ & Voluntary programme for disabled & Membership & $\mathrm{D}$ \\
\hline $\begin{array}{l}\text { 2002: New Deal for } \\
\text { lone parents }\end{array}$ & $\begin{array}{l}\text { Introduction of compulsory job-related } \\
\text { interview (non-compulsory before) }\end{array}$ & $\begin{array}{l}\text { Behaviour/ } \\
\text { Conduct }\end{array}$ & $\mathrm{R}$ \\
\hline New Deal for partners & $\begin{array}{l}\text { Mandatory participation in interview for JSA } \\
\text { claimants under } 45 \text { years (non-mandatory before) }\end{array}$ & $\begin{array}{l}\text { Behaviour/ } \\
\text { Conduct }\end{array}$ & $\mathrm{R}$ \\
\hline 2004 & $\begin{array}{l}\text { Entry into NDYP and ND } 25+\text { after } 3 \text { months of } \\
\text { unemployment }\end{array}$ & $\begin{array}{l}\text { Behaviour/ } \\
\text { Conduct }\end{array}$ & $\mathrm{R}$ \\
\hline
\end{tabular}

Sources: Walker \& Wiseman (2003); Annesley \& Gamble (2004); Taylor-Gooby et al. (2004); Clasen (2005); Clasen \& Clegg (2007).

Note: the classification of reforms in terms of level of conditionality and direction draws on the scheme of Clasen \& Clegg (2007); R: recommodification, D: decommodification. 
Table 4.4 OECD replacement rates of unemployment benefits for United Kingdom, 1989-2007

\begin{tabular}{lllllllllll}
\hline & 1989 & 1991 & 1993 & 1995 & 1997 & 1999 & 2001 & 2003 & 2005 & 2007 \\
\hline $\begin{array}{l}\text { OECD summary } \\
\text { measure }\end{array}$ & 18 & 18 & 19 & 18 & 18 & 17 & 13 & 13 & 12 & 12 \\
\hline & & $1997^{\mathrm{a}}$ & 2001 & 2002 & 2003 & 2004 & 2005 & 2006 & 2007 \\
\hline $\begin{array}{l}\text { Net replacement } \\
\text { rate }\end{array}$ & 50 & 41 & 41 & 41 & 41 & 41 & 40 & 40 \\
\hline
\end{tabular}

Source: Summary measure: OECD (2010a). Net replacement rate for 1997: OECD (1999), for 2001-07: OECD (2010b).

Notes: The OECD summary measure is defined as the average of the gross unemployment benefit replacement rates for two earnings levels, three family situations and three durations of unemployment. The net replacement rate for long-term unemployed is the compensation for a long-term unemployed single person with 100 per cent of average wage earner 1997-2007. a. the 1997 figures are not based on the average wage earner, but on the 100 per cent average production worker, so the 1997 figures are not directly comparable, as the OECD changed the definition of the net replacement rate. Bold figures represent post-reform years.

\subsection{Party competition around welfare state reforms, 1997-2005}

The United Kingdom has a FPTP electoral system with single-member constituencies rather than the party lists typically found in PR systems. The British case thus allows us to test the proposition that Third Way social democrats cannot be challenged by the type of dangerous competitor outlined in Chapter 2 if the electoral system is FPTP. This electoral system typically leads to restricted competition between two major parties, or between two major parties and a minor third party that is able to survive thanks to regional strongholds. Under these circumstances, I expected a dealignment of social democratic core constituents who would stay home due to the lack of credible alternatives. The following section outlines the party competition with which New Labour was confronted after 1997, in order to formulate the respective proposition to guide the analysis that follows.

First, some preliminary remarks on Labour's programmatic realignment when the party was in opposition between 1979 and 1997. Having lost the general elections in 1983 and 1987 and given the relative strength of the SDP-Liberal Alliance, Labour began to modernise its programme under its new leader, Neil Kinnock. The defeat in the 1992 election is seen as having accelerated Labour's programme of change (e.g. Merkel et al. 2008: 41). The change of leadership from Neil Kinnock to John Smith and 
Tony Blair went in line with a rightward shift of the party in general, and on welfare issues in particular (e.g. Heffernan 2001: chap. 5; Rueda 2007: $208 \mathrm{ff}$ ). Labour also reformed its party organisation and emancipated itself from the trade unions. To expand its electoral appeal, the party changed its name to New Labour, indicating a symbolic break with Labour's traditional commitment to the welfare state and its tax-and-spend image.

New Labour regained power in the 1997 general election, as the party was now able to attract a considerable share of middle-class voters without having lost its working-class core constituency (see Table 4.1 above). Even though Labour changed its commitment to the welfare state and was responsible for a recommodifying social policy, a serious nationwide competitor on welfare grounds did not exist or emerge after New Labour came into office. This implies that the configuration of party competition in Britain between 1997 and 2005 was rather stable (Bara \& Budge 2001 for the first term; Helms 2006). The Conservative Party remained the main opponent on the right and the Liberal Democrats were positioned to the left, but with a social liberal stance. ${ }^{3}$ This will be discussed here to hypothesise on the electoral consequences of New Labour's welfare state reforms and the party's ideological shift.

Labour's traditional competitor, the Conservatives, continued to propose market-liberal policies that did not represent the political preferences of Labour's traditional core constituency. The Conservatives' electoral performance during Tony Blair's first two terms (1997-2005) was relatively poor. The leadership changed several times, but the party did not become significantly more 'welfare-friendly' and undertook a move to the right in the late 1990s (Lynch \& Garner 2005: 542). New Labour countered Conservative attempts to attract voters on socio-cultural issues such as immigration or asylum with tough legislation and populist rhetoric (cf. Butler \& Kavanagh 2002: 20; Lynch \& Garner 2005: 541). Hence, we would not expect the Conservatives to be a serious contender for working-class and lower white-collar votes under the aegis of New Labour. ${ }^{4}$

The Liberal Democrats, the third party on the national level, has presented itself as a centre-left party, in particular to the left of Labour after Labour's ideological realignment (e.g. Bara \& Budge 2001; Lynch \& Garner 2005; Norris \& Wlezien 2005: 671; Kriesi \& Frey 2008). Its potential to attract Labour's core constituency is ambivalent in terms of my framework on challenger parties, though. The party has occasionally attacked New Labour on welfare issues and on, for example, the British involvement in the Iraq war, in order to gain protest votes (Lynch \& Garner 2005; Kriesi \& Frey 2008; Russell \& Cutts 2009). However, the party is 
strategically constrained in attracting Labour core voters for two reasons. First, appealing to Labour core supporters reduces the party's prospects of attracting disillusioned Conservatives or of defending constituencies held by the Liberal Democrats against the Conservatives. This marks a trade-off for the party in targeting Labour voters, as the Liberal Democrats may fear losing their own heartland and constituencies held with narrow majorities. Russell \& Cutts (2009: 78) have claimed that the party appealed more to Labour core voters by exploiting their dissatisfaction with the New Labour project. This would qualify the Liberal Democrats as a mainstream challenger that tries to capitalise on the transformation of the social democratic party by changing its own strategic appeal.

A second aspect of the Liberal Democrats' electoral appeal - its social liberal stance - undermines the party's prospects of attracting working class votes on the welfare dimension. As shown in Chapter 2, social democratic core voters, such as blue-collar workers, tend towards authoritarian views on the libertarian-authoritarian dimension (e.g. Scheuregger \& Spier 2007; Houtman et al. 2008; Kriesi et al. 2008), whereas the Liberal Democrats are on the libertarian side on issues such as immigration or law and order (Kriesi \& Frey 2008). Moreover, the party turned to the left on several non-economic issues, such as the Iraq war and ethnic minorities, in Labour's second term (Norris \& Wlezien 2005: 669). This should have hampered the party's attempts to attract supporters from Labour's rank and file, as the party's image did not match the attitudes of social democratic core supporters on socio-cultural issues. In sum, the Liberal Democrats' potential to win social democratic core voters under New Labour seemed ambiguous. Nevertheless, the rising support for the party in the period between 1997 and 2005 demands inspection.

Other parties were not able to attack Labour effectively. The electoral system marginalised those parties that I have identified as dangerous competitors for reform-minded social democrats. There was no nationwide left-socialist party or right-wing authoritarian party to seriously challenge New Labour, as the threshold is high and voters are aware of the effect of the electoral system in Britain (Dunleavy 2005; Dunleavy \& Margetts 2005). ${ }^{5}$ Dunleavy (2005) confirms that the British electoral system has a penalising effect on minor parties, showing that they receive considerable support in elections held with PR, such as the elections for the European Parliament, to the disadvantage of the two major parties.

Left-socialist and right-wing parties, such as the United Kingdom Independence Party (UKIP) or the British National Party (BNP), as well as other minor parties, enjoyed some progress after New Labour came into 
office in 1997 (Webb 2005). This was only translated into parliamentary seats for the far-left-wing Respect Party, which won a constituency in London in the 2005 general election, mainly on the basis of opposition to the Iraq War (cf. Webb 2005: 767ff). Accordingly, Labour's transformation may have opened the flank for some minor parties to attract Labour's core supporters, which the analysis has to control for, even though this is hardly expected to produce clear patterns of realignments. ${ }^{6}$

As there was no serious contender for Labour after its ideological shift, I would expect Labour to face its strongest electoral challenge from absenteeism. In terms of the framework on party competition, given the FPTP electoral system, the British case should reveal a dealignment of social democratic core constituents, but no realignment with other competitors. After describing the data source, I analyse this proposition empirically.

\subsection{Data and variables}

The data used for the analyses are the British General Election Studies (BES) for the elections in 1992, 1997, 2001 and 2005 (BES 1992, 1997, 2001, 2005). The 1992 and 1997 studies are only used for descriptive purposes. The BES provide the traditional data source for the study of electoral behaviour in Britain, as they offer a wide range of variables and items. The analysis below consists of a descriptive and statistical part.

In the descriptive part, I analyse whether the perception of the Labour Party as a party looking after the interests of the working class and the unemployed changed after 1997. This is a proxy for the evaluation of Labour reforms after 1997, as the reforms have been classified as conflicting with the interests of Labour's core constituency due to their recommodifying effects. ${ }^{7}$ It should capture the attitude towards Labour's policy change quite well given the nature of the reforms, which were against the interests of these groups, as spelled out above. Neither the BES nor other data sources, such as the 'British Social Attitudes Surveys', contain better variables that can capture attitudes towards Labour's social policy over time.

Belonging to Labour's core constituency is a dummy variable (yes/ no), which was obtained via the variable of the respondents' social class. Workers and lower white-collar employees have been coded as the core constituency. Party choice was obtained through the respective variables in the BES and consists of five categories (1 'Labour', 2 'Conservatives', 3 'Liberal Democrats', 4 'All other parties', 5 'Non-voting'). ${ }^{8}$ 
The statistical part examines whether changed perceptions of Labour led to an electoral setback for the party and to a dealignment of Labour's core constituency. This was done by applying logistic regression models with party choice as the dependent variable. For the 2001 election, the independent variables consist of two measures, the respondents' voter group and an index for the perception of the Labour Party. The voter group variable distinguishes between the non-core constituency, a non-aligned part of the core constituency and the aligned part of the core constituency. Aligned core constituency means belonging to Labour's core constituency, as defined above, and having voted for Labour in 1997. ${ }^{9}$ The index measures whether Labour is perceived as looking after the interests of the working class and the unemployed and was constructed through the respective items. It takes a value 'o' if Labour is seen as representing the interests of both groups well; ' 1 ' if a respondent sees Labour as not looking after the interests of either the working class or the unemployed; and ' 2 ' if Labour is perceived as disregarding the interests of both groups. The rationale of the index is to measure the effect of dissatisfaction with Labour's policy change after 1997 on party choice. For the 2005 election, I used the same dependent and independent variables, but the voter group variable consists of a further category for abstention in 2001 and belonging to Labour's core constituency. Although we lack panel data for a stricter test, this allows us to assess whether the respective voters really defected from Labour after 1997 or came back to their 'natural' party.

\subsection{Results}

Attitudes towards Labour's policy and voting behaviour after 1997

In this first step of the analysis, I demonstrate that the public perception of the Labour Party changed after the party took office in 1997. As mentioned, attitudes towards Labour's policy change and the party's welfare policy after 1997 are operationalised through proxy variables examining whether respondents perceive the Labour Party as representing the interests of the working class and the unemployed respectively. These variables should capture attitudes towards New Labour and its social policy record quite well, as Labour has traditionally been seen as the party of the working class and the lower social stratum due to its ideological commitment to the welfare state. As Table 4.5 shows, the share of respondents that did not perceive Labour to represent the interests of the working 
class and the unemployed clearly increased from 1997 to 2001, the period in which Labour began to implement the New Deal reforms.

Table 4.5 Perception that Labour Party looks after interests of social groups, 1997-2005 (per cent)

\begin{tabular}{lccc}
\hline \multicolumn{5}{c}{ Share of respondents not perceiving Labour to represent } & working-class interests \\
& 1997 & 2001 & 2005 \\
\hline Non-core constituency & 5.9 & 33.5 & 33.4 \\
Core constituency & 6.8 & 37.6 & 38.4 \\
All respondents & 6.3 & 35.1 & 35.6 \\
\hline \multicolumn{2}{r}{ Share of respondents not perceiving Labour to represent the interests of the unemployed } \\
& 1997 & 2001 & 2005 \\
\hline Non-core constituency & 12.9 & 31.8 & 18.7 \\
Core constituency & 14.8 & 36.1 & 28.7 \\
All respondents & 13.8 & 33.5 & 23.1 \\
\hline
\end{tabular}

Source: Own calculations with British Election Studies 1997-2005.

The figures reveal that Labour's image as a working-class party changed dramatically after 1997. In 1997, less than 10 per cent of the respondents did not perceive Labour as representing the interests of the working class in the UK; in 2001 and 2005, more than one out of three respondents felt that way. Similarly, the perception that Labour represents the interests of the unemployed changed considerably after 1997, but the change was not as pronounced as that for the working class. From 2001 to 2005 these shares declined slightly, but remained twice as high as in 1997 among the core constituency. This means that it was not the new label that induced the changed perception of Labour, as the party still had its old-style working class image at the 1997 election.

Rather, the results suggest that it was New Labour's actual policy that affected the attitudes towards the party and not simply the transformation into New Labour in the mid-1990s. In 2001 and 2005, a sizable share of voters no longer perceived Labour to be reflecting the concerns of the working class or the unemployed.

The next step is to look at descriptive statistics on party shares to get a first indication of electoral change during the period of Labour's programmatic transformation and the welfare reforms. Table 4.6 yields some first descriptive evidence for the expected non-voter trade-off for Labour after the party's policy change. 
Table 4.6 Party shares and non-voting among Labour Party's core constituency, 19922005 (per cent)

\begin{tabular}{lrrrr}
\hline Core constituency & 1992 & 1997 & 2001 & 2005 \\
\hline Labour & 42.5 & 48.1 & 37.0 & 29.3 \\
Conservatives & 28.8 & 14.5 & 14.0 & 10.7 \\
Liberal Democrats & 11.0 & 11.6 & 10.5 & 11.0 \\
Other parties & 2.8 & 4.3 & 3.5 & 5.2 \\
Non-voters & 14.7 & 21.6 & 35.1 & 43.8 \\
\hline Non-core constituency & 1992 & 1997 & 2001 & 2005 \\
\hline Labour & 19.0 & 33.0 & 30.4 & 26.4 \\
Conservatives & 49.9 & 31.3 & 24.6 & 29.8 \\
Liberal Democrats & 18.5 & 16.8 & 16.3 & 17.4 \\
Other parties & 2.4 & 4.4 & 3.2 & 3.0 \\
Non-voters & 10.2 & 14.6 & 25.7 & 23.4 \\
\hline
\end{tabular}

Source: British Election Studies 1997-2005. Figures do not always add up to 100 per cent due to rounding.

The figures in Table 4.6 demonstrate that Labour lost considerable support among those classes conceptualised as the social democratic core constituency, as the party's share dropped from 48 to 29 per cent after 1997. Similarly, the share of non-voters doubled from 1997 to 2005, which confirms the non-voter trade-off for New Labour. There is almost a substitution of the numbers between the respective cells if we compare the results for 1997 and for 2005 .

The figures for the other parties show that no competitor was able to mobilise among Labour's core constituency after $1997 .{ }^{10}$ Comparing those figures with the respective results among the non-core constituency displays a much more moderate decline, as Labour only lost 7 percentage points in this group. Accordingly, the non-voter share among these social classes only increased by 8 percentage points, and not by 22 percentage points, as among the social democratic core constituency. Again, all other parties show no pattern of realignments among those voters, as their shares remain relatively stable.

These two developments, the changed perception of the Labour Party and decreasing support among the party's core voter base, provide initial evidence that Labour's ideological transformation and the welfare state reforms under New Labour after 1997 also had electoral consequences. The next step is to model these electoral consequences. 
As discussed above, I present conditional probabilities obtained from multinomial logistic regression models to investigate whether the changed image of the Labour Party has led to decreasing support among its core voter base and gains for competitor parties. ${ }^{11}$ As explained above, the dependent variable was party choice and the independent variables were the respondents' voter group and an index for the perception of the Labour Party. I focus on the aligned core constituency's vote choice in 2001. I always refer to aligned core constituents perceiving Labour to represent the interests of the working class and the unemployed as the reference group to examine the effects of dissatisfaction with Labour on electoral outcomes. Table 4.7 presents the results for the 2001 general election.

Table 4.7 Predicted probabilities of vote choice among aligned core constituency by perception of Labour, 2001

\begin{tabular}{lccc}
\hline & \multicolumn{3}{c}{ Labour looks after interests of working class/the unemployed } \\
$\begin{array}{l}\text { Estimated party } \\
\text { choice 2001 }\end{array}$ & $\begin{array}{l}\text { Looks after interests } \\
\text { of both groups }\end{array}$ & $\begin{array}{l}\text { Looks after interests } \\
\text { of only one of the } \\
\text { groups }\end{array}$ & $\begin{array}{l}\text { Disregards interests } \\
\text { of both groups }\end{array}$ \\
\hline Labour & 77.5 & $62.5^{*}$ & $36.8^{*}$ \\
Conservatives & 1.8 & 3.4 & 4.6 \\
Liberal Democrats & 6.7 & 10.0 & $17.4 !$ \\
Other parties & 2.3 & 4.8 & $11.9 !$ \\
Non-voting & 11.7 & 19.4 & $29.3^{*}$ \\
Overall & 100 & 100 & 100 \\
\hline
\end{tabular}

Source: Predicted probabilities obtained from multinomial logistic regression model using Clarify.

Note: The number of simulations to obtain the probabilities was set to $1,000$. ! $p<.10 ;{ }^{*} p<.05$.

The figures reveal that Labour is still able to attract about eight out of ten core constituents as long as the party is regarded as representing the interests of both the working class and the unemployed. Other parties play no role under these conditions (left-hand column). However, if core constituents no longer feel that Labour looks after the interests of these social groups, then they significantly defect from New Labour. This is especially pronounced among former core voters who perceive Labour to be disregarding the interests of both groups. Here, the Liberal Democrats 
and minor parties make significant gains compared to the control group. The Conservatives make no significant gains, in line with expectations.

What is most striking is the significant turn towards abstention on the part of disaffected Labour core voters, which almost triples in the righthand column compared to the left-hand column. Summing up the analysis for 2001, the analysis of the conditional probabilities confirms the expected non-voter trade-off for the Labour Party after engaging in welfare state reform and an ideological shift. As shown in Table 4.7, turnout in the UK dropped in 2001, particularly among disappointed Labour core supporters. This can be explained by a changed perception of Labour, as the analysis of the conditional probabilities has demonstrated. The next question is whether this pattern is confirmed by the 2005 election, and I now conduct a similar analysis using the 2005 dataset.

\section{Electoral effects of Labour's policy change, 2001-05}

As for the 2001 election, I obtained the conditional probabilities from a multinomial logistic regression model to assess whether the alignment to the Labour Party among its core supporters is contingent on the attitude towards the party. The variables used are the same as in the analysis above, but I expanded the model with a dummy for voters who belong to Labour's core constituency and abstained in 2001 to assess whether they had returned to Labour. ${ }^{12}$ Table 4.8 presents the results for aligned Labour core voters and non-voters from the 2001 election belonging to Labour's core voter base.

The table's upper half indicates that Labour lost core supporters in the 2001 election who did not perceive Labour to be representing the concerns of the two groups. However, no other option differs significantly from the control group (the left-hand panel), even though non-voting has doubled among disillusioned core voters. As in the 2001 election, the Liberal Democrats and minor parties made some advances, as Labour's image had been damaged (the differences are not significant). Again, the Conservatives played no role among these voters.

The table's lower half shows that Labour did not regain core voters who had abstained four years previously. Abstention among those respondents remained at 70 per cent and above. Surprisingly, this was also true for those who perceived Labour to be looking after the interests of the working class and the unemployed. The Liberal Democrats and minor parties were able to attract small shares of former non-voters among the social democratic core constituency, but non-voting remained predominant here. 


\begin{tabular}{|c|c|c|c|}
\hline \multirow[b]{3}{*}{$\begin{array}{l}\text { Estimated party } \\
\text { choice } 2005\end{array}$} & \multicolumn{3}{|c|}{ Labour vote in 2001} \\
\hline & \multicolumn{3}{|c|}{ Labour looks after interests of working class/the unemployed } \\
\hline & $\begin{array}{l}\text { Looks after interests } \\
\text { of both groups }\end{array}$ & $\begin{array}{l}\text { Looks after interests } \\
\text { of only one of the } \\
\text { groups }\end{array}$ & $\begin{array}{l}\text { Disregards interests of } \\
\text { both groups }\end{array}$ \\
\hline Labour & 67.8 & $36.9^{*}$ & $31.7^{*}$ \\
\hline Conservatives & 4.6 & 9.2 & 6.0 \\
\hline Liberal Democrats & 7.5 & 15.8 & 17.4 \\
\hline Other parties & 5.1 & 13.1 & 15.1 \\
\hline \multirow[t]{3}{*}{ Non-voting } & 14.9 & 24.9 & 29.9 \\
\hline & \multicolumn{3}{|c|}{ Abstention in 2001} \\
\hline & \multicolumn{3}{|c|}{ Labour looks after interests of working class/the unemployed } \\
\hline $\begin{array}{l}\text { Estimated party } \\
\text { choice } 2005\end{array}$ & $\begin{array}{l}\text { Looks after interests } \\
\text { of both groups }\end{array}$ & $\begin{array}{l}\text { Looks after interests } \\
\text { of only one of the } \\
\text { groups }\end{array}$ & $\begin{array}{l}\text { Disregards interests of } \\
\text { both groups }\end{array}$ \\
\hline Labour & 3.3 & 1.0 & 0.8 \\
\hline Conservatives & 12.2 & 14.1 & 8.2 \\
\hline Liberal Democrats & 7.5 & 9.0 & 9.1 \\
\hline Other parties & 4.0 & 5.6 & 6.3 \\
\hline Non-voting & 73.0 & 70.3 & 75.6 \\
\hline
\end{tabular}

Source: Predicted probabilities obtained from multinomial logistic regression using Clarify. Note: The number of simulations to obtain the probabilities was set to $1,000$. ! $p<.10 ;{ }^{*} p<.05$.

Hence, the results indicate that Labour did not recapture the non-voters among its core voter base that it had previously lost due to its policy change. This confirms the claims about the proposed effect of an FPTP system for the electoral fortunes of Third Way social democrats among their traditional core constituencies. Thanks to the British electoral system, Labour did not face a serious competitor that was able to attract dissatisfied core voters.

\subsection{Conclusion}

The goal of this chapter was to test the proposition that an FPTP electoral system leads to a dealignment of core constituents from Third Way social democrats, but not to realignments with other parties, on the grounds 
that this electoral system effectively prevents the emergence of dangerous challengers. This was done by analysing the electoral consequences of Labour's ideological transformation and the welfare state reforms under New Labour after 1997. The British Labour Party was traditionally committed to classic social democratic principles, the decommodification of labour being the most important in terms of my theoretical framework. This allowed the party to form an alignment with particular social classes reflecting the party's core constituency in the post-war era. After Labour changed its commitment to the welfare state in the 1990s and introduced some recommodifying welfare state reforms after 1997 (most notably the New Deal programmes), the alignment was examined as set out in Chapter 2. Given the nature of the party competition as a consequence of the British electoral system, I hypothesised that Labour mainly faced dealignment of the party's core supporters thanks to the absence of other welfare or leftist parties. The Conservatives were not expected to be a serious competitor due to their market-liberal position, whereas the Liberal Democrats were expected to have an ambiguous appeal.

The results confirmed these expectations: Labour was exposed to a dealignment of core constituents into the non-voter camp when New Labour was no longer perceived as upholding working-class interests. Accordingly, many dissatisfied Labour core supporters defected in 2001. While they did not return in the 2005 election, Labour maintained its position as the strongest party after 1997 . One reason for this is the absence of a systematic realignment of these voters to another party. However, the Liberal Democrats were able to benefit from the disaffection with New Labour, as the party made some gains among Labour's core constituency that seem to have lasted into the 2005 election. The party also benefited indirectly among these voters, as the lower turnout of former Labour core voters implies greater weight of the existing Liberal Democrats' backing among the working class at the ballot. However, we should be careful to understand this as an outright realignment, as the party is the successor to the SDP - a right-wing splinter of Labour - and has always enjoyed some backing among Labour's core voter base. Similarly, the Liberal Democrats made gains under the aegis of Tony Blair, but the party was no stronger than its predecessors in the 1970 or or 1980 . This is true for both the party shares and the electoral performance among voters conceptualised as the social democratic core constituency.

Minor parties, especially those on the fringes of the party system, made some gains after 1997, but failed to produce any outright electoral change in line with the electoral system argument. Nevertheless, given my argu- 
ments on dangerous challengers for Third Way social democrats, there are two minor parties whose recent electoral prospects deserve some attention. First, the left-socialist Respect Party won the constituency of Bethnal Green and Bow against the Labour incumbent in the 2005 election. The party mobilised against the Iraq War, but it also opposed the economic reforms implemented under previous Tory and Labour governments (Webb 2005: 769) and campaigned for their withdrawal. This shows that although left-socialist parties are marginalised under an FPTP system, they may benefit from disaffection with Third Way social democracy under certain favourable context conditions. This was not a lasting development, since the party lost the seat with the 2010 election and was marginalised due to internal quarrels after 2005 .

Second, the transformation of the Labour Party can be related to the rise of a right-wing authoritarian party, the BNP. The BNP fits the type of right-wing authoritarian challenger to some extent, although it is clearly extremist. While the party was unable to translate this into parliamentary representation, the BNP's vote shares increased from 0.1 per cent in 1997 to 2.0 per cent in the 2010 election. ${ }^{13}$ Labour's ideological realignment seemed to have fuelled this development, as the BNP's gains typically occurred in white working-class constituencies and thus former Labour strongholds (Denver \& Fisher 2009: 37; Goodwin 2010). It has been suggested that this is a consequence of disappointment with New Labour. Recent research has identified the BNP as a dangerous competitor in line with my framework when it comes to voting behaviour. The social profiles of current BNP voters and traditional Labour supporters are remarkably similar, with a large overrepresentation of the working class among the BNP vote (Ford \& Goodwin 2010; Goodwin et al. 2010). This provides some evidence that the transformation of the Labour Party can be seen as creating a favourable context for the strengthening of a right-wing authoritarian challenger, even under an unfavourable electoral system.

Summing up, in line with the theoretical expectations, this chapter's main implication is that the Labour Party mainly faced a dealignment of the party's core constituency after having abandoned its traditional social democratic principles. No other party was able to foster an outright realignment and no nationwide left-wing competitor emerged, although the Liberal Democrats and minor parties such as the BNP made some gains among the social democratic core constituency at the expense of New Labour. These developments are, of course, determined by the FTPT electoral system, which means that a lesser electoral setback is suffered by the 
Labour Party if it engages in recommodification than that suffered by its social democratic sister parties in other countries.

Nonetheless, future research should focus on the advance of the Liberal Democrats and the BNP among Labour's traditional voter base. Whereas the former party may have a hard time fostering a lasting realignment among these voters due to its social-liberal stance and its recent coalition with the Conservatives, the latter may confront Labour with some additional trade-offs. If the BNP successfully combines populist appeals on welfare issues with its authoritarian stance, the consequence could be a weakened Labour Party, even though the BNP gains rarely translate into parliamentary representation.

The next chapter looks at the case of the German SPD between 1998 and 2009, and examines what happens when Third Way social democrats are challenged by a left-socialist competitor that is not disadvantaged by the electoral system. 



\section{Germany}

This chapter investigates what happens when Third Way social democrats are confronted with a left-socialist challenger under a PR system. The case is that of Germany, where the social democrats (SPD) engaged in pathbreaking labour market reforms and faced the Left Party as a new competitor due to this policy change. The latter party fits the type of 'dangerous left challenger', as this chapter will illustrate. We also examine the competition from a mainstream Christian democratic party, as the SPD's biggest competitor. Hence, the chapter examines the electoral consequences of the welfare state reforms introduced by social democratic governments in Germany from 1998 to 2009.

As with the Labour Party in Britain, the German SPD (Sozialdemokratische Partei Deutschlands) returned to power in the late 1990 os with a new label that accentuated the party's move towards the centre, 'Die Neue Mitte' (the New Centre). ${ }^{1}$ However, the reform trajectory was different from that of New Labour, as the SPD-Greens coalition only implemented moderate reforms in its first electoral term (1998-2002). The second term (2002-05) saw the introduction of the path-breaking Agenda 2010 reform package, including the highly controversial Hartz labour market reforms. This was a remarkable departure from the SPD's traditional position on social policy (e.g. Kemmerling \& Bruttel 2006; Fleckenstein 2008; Debus 2008). The SPD was largely consistent in its adherence to its reform agenda in the Grand Coalition with the Christian democratic parties (CDU/ $\mathrm{CSU}$ ) from 2005 to 2009 , which also was responsible for sweeping pension reforms.

During the first years in government, the SPD lacked a left-wing challenger, as the post-communist Party of Democratic Socialism (PDS) was relatively marginalised and its electoral importance restricted to the eastern part of Germany. This changed after the Hartz reforms and Agenda 2010, when the PDS merged with a couple of SPD dissidents to form the Left Party. This new party turned into a nationwide left-wing challenger to the SPD: the party easily surpassed the 5 per cent threshold in the 2005 
election, which was called after the implementation of the Hartz reforms. There was no competitive authoritarian right-wing party during the period of investigation, as outlined in Chapter 2. The case of Germany thus allows me to investigate the proposed electoral danger of left-socialist parties for Third Way social democrats.

\subsection{The social policy of German social democracy}

As discussed in Chapter 2, social democratic parties tie their core constituencies by advocating particular political goals and aspirations, decommodification of labour being the most important of these. Drawing on this conception of the alignment of the social democratic core constituency, this section briefly illustrates the SPD's traditional social policy aspirations and its ideological commitment to the welfare state. The German SPD introduced two party manifestos after 1945: the 'Godesberger Programm' in 1959 and the 'Berliner Programm' in 1989. Even though the manifestos originate from different historical contexts, they indicate commitments to a particular social policy and to the welfare state, in line with Esping-Andersen's approach. The party committed itself to generous and institutionalised income maintenance in case of unemployment, sickness or old age (SPD 1959, 1989). Moreover, both manifestos pointed to income redistribution and wage compression as a means to improve the living standards of the less well-off, by alleviating the effects of pure market allocation. Collective action and institutionalised wage bargaining were seen as the means to realise this objective. The ties to the trade unions and their importance were emphasised in both programmes, and the SPD's traditional programmatic commitment referred to the realisation of decommodification and its various aspects outlined above. Furthermore, both manifestos appealed to the traditional social democratic principles of egalitarianism and solidarity, as emphasised by Huo (2009: chap. 2).

In the political praxis, the SPD was - together with the CDU/CSU the driving force in the expansion of the German welfare state after the Second World War (e.g. Huber \& Stephens 2001: 146ff; Schmidt 2006; Wehler 2008: 257ff). Before the party participated in government for the first time in 1966, the SPD often supported the Christian democrats' proposals to expand the welfare state, in particular pensions. Moreover, the social democratic proposals went beyond those of the Christian democratic competitor in terms of generosity and universality. For instance, in the first Grand Coalition with the CDU/CSU (1966-69), the SPD managed 
to raise replacement rates for sickness insurance to 100 per cent (Huber \& Stephens 2001: 151). Until the mid-1970s, the social-liberal coalition (1969-82), consisting of the SPD and the liberal party (FDP), expanded the welfare state in a faster and broader manner than any previous government (Schmidt 2006: 142f; Wehler 2008: 264ff). New groups were now integrated into the social security system, making it more universal. Moreover, social security benefits and the replacement rates of various social programmes were increased and an encompassing pension reform was implemented. This went in line with rising white-collar support for the party, which had begun in the 1960 .

After the SPD returned to opposition in 1982, the party criticised the welfare politics of the centre-right CDU/CSU and FDP government for engaging in retrenchment policies, even though the Kohl government only introduced minor cutbacks and incremental changes aiming at budget consolidation (cf. Schmidt 2003: 241). ${ }^{2}$ The political discussion intensified after German unification in 1990 as a result of the escalating financial pressure, high unemployment rates and the increasingly divergent political positions of the two major parties. In its last electoral term (1994-98), the Kohl government introduced several welfare state reforms aimed at fiscal consolidation and adapting the welfare state to the new economic and societal context. The SPD ran its 1998 election campaign against these reforms, claiming that they would cause social hardships and promising to withdraw them (e.g. von Alemann 1999: 4of; Feist \& Hofmann 1999; Picot 2009: 172).

This brief summary of the SPD's policy paradigms and its actual social policy record in the period 1949-98 reveals that the party's policy was in line with the theoretical framework on the alignments of social democratic parties with respect to social policy. The German SPD advocated decommodification, egalitarianism and solidarity as its basic programmatic commitments and implemented these policies when it was in office. Hence, the SPD should have appealed to particular social classes representing the party's core constituency during this period. The next section describes the SPD's electoral performance among its core constituency over time.

\subsection{Alignment of the social democratic core constituency in Germany}

Table 5.1 reports the party shares of the SPD and its main competitors on welfare, the Christian Democrats and the PDs/Left Party, in classes identified as the social democratic core constituency prior to the reforms 
introduced by the red-green government. ${ }^{3}$ To demonstrate electoral performance over time, the tables also show the parties' overall share of votes in federal elections since 1965.

Table 5.1 Party choice by selected social classes, Germany 1969-98

\begin{tabular}{lllllllllll}
\hline & & 1969 & 1972 & 1976 & 1980 & 1983 & 1987 & 1990 & 1994 & 1998 \\
\hline SPD & RNM & 50 & 61 & 78 & 50 & 48 & 41 & 40 & 55 & 60 \\
& Skilled & 63 & 68 & 57 & 62 & 46 & 55 & 39 & 44 & 53 \\
& Unskilled & 52 & 62 & 61 & 56 & 49 & 42 & 48 & 41 & 39 \\
\multirow{5}{*}{ CDU/CSU } & RNM & 39 & 33 & 16 & 35 & 42 & 46 & 46 & 31 & 30 \\
& Skilled & 34 & 24 & 39 & 28 & 48 & 37 & 43 & 42 & 29 \\
& Unskilled & 45 & 33 & 38 & 30 & 45 & 46 & 41 & 47 & 51 \\
\multirow{5}{*}{ PDS/Left } & RNM & - & - & - & - & - & - & - & 2 & 3 \\
& Skilled & - & - & - & - & - & - & - & 6 & 7 \\
& Unskilled & - & - & - & - & - & - & - & 6 & 2 \\
\hline
\end{tabular}

Sources: German National Election Studies 1969-98.

Notes: Figures for 1969 to 1990 refer to Western Germany, 1994 and 1998 refer to unified Germany. RNM: Routine non-manual employees.

Table 5.1 illustrates that the SPD was indeed able to form an alignment with classes conceptualised as the social democratic core constituency in Western Germany, and later in unified Germany. Originally predominantly a workers' party, the SPD also targeted lower-white collar employees with the Godesberg Programme from 1959. In this vein, the alignment of routine non-manual employees with the SPD materialised after 1965 and peaked in the 1970 . The strength of the alignment of the classes considered to be the social democratic core constituency has fluctuated over time, however, at least to some extent due to the general political context in Germany. The results until 1983 must be seen in the context of the two-and-a-half-party system, with two clearly dominant parties and a minor third party, before the Greens gained parliamentary representation and the party system became more factionalised. However, it has been maintained that this did not increase polarisation on welfare issues, as the centripetal competition on this issue prevailed (Zohlnhöfer 2001; Padgett 2005; Picot 2009). ${ }^{4}$ During the Kohl era (1982-1998), both large parties wooed the social democratic core constituency and the differences between them decreased somewhat. 
In the new Länder, the CDU/CSU mobilised working class votes in the years between 1990 and 94, something that was attributed to the unification (Dalton \& Bürklin 1995), whereas the SPD was able to attract lower white-collar employees. Support for the SPD among workers grew until 1998, though, which at least indicates that the voting patterns conformed to the western patterns as the effects of unification became weaker. ${ }^{5}$

The SPD victory in 1998 reflected a stronger alignment of the social democratic core constituency, as shown by the respective vote shares for both parts of Germany. The party's 1998 electoral winning formula was based on Schröder's ability to mobilise swing and middle-class votes by his electoral appeal on the one hand, and SPD chairman Oskar Lafontaine's ability to mobilise the social democratic core constituency with a more orthodox appeal on the other hand (von Alemann 1999; Feist \& Hofmann 1999; Niedermayer 2002, 2006: 121). The striking feature is that the SPD experienced a steady decline among the electorate after the party came into government in 1998 with a pronounced Third Way agenda, labelled 'Die Neue Mitte.' The decline was moderate in the first electoral term and seemed to benefit the Christian democrats. Table 5.2 shows the vote shares of the parties that gained parliamentary representation after the unification.

Table 5.2 Vote shares for federal elections, Germany 1965-2009

\begin{tabular}{lrrrrrrrrrrrrr}
\hline & 1965 & 1969 & 1972 & 1976 & 1980 & 1983 & 1987 & 1990 & 1994 & 1998 & 2002 & 2005 & 2009 \\
\hline SPD & 39.3 & 42.7 & 45.8 & 42.6 & 42.9 & 38.2 & 37.0 & 33.5 & 36.4 & 40.9 & 38.5 & 34.2 & 23.0 \\
CDU/CSU & 47.6 & 46.1 & 44.9 & 48.6 & 44.5 & 48.8 & 44.3 & 43.8 & 41.5 & 35.1 & 38.5 & 35.2 & 33.8 \\
FDP & 9.5 & 5.8 & 8.4 & 7.9 & 10.6 & 7.0 & 9.1 & 11.0 & 6.9 & 6.2 & 7.4 & 9.8 & 14.6 \\
Greens & - & - & - & - & 1.5 & 5.6 & 8.3 & $5.0^{\mathrm{a}}$ & 7.3 & 6.7 & 8.6 & 8.1 & 10.7 \\
PDS/Left & - & - & - & - & - & - & - & 2.4 & 4.4 & 5.1 & 4.0 & 8.7 & 11.9 \\
Others & 3.6 & 5.4 & 1.0 & 0.9 & 0.4 & 0.4 & 1.5 & 4.2 & 3.5 & 5.7 & 2.8 & 3.8 & 6.0 \\
Turnout & 86.8 & 86.7 & 91.1 & 90.7 & 88.6 & 89.1 & 84.3 & 77.8 & 79.0 & 82.2 & 79.1 & 77.7 & 70.8 \\
\hline
\end{tabular}

Source: http://www.Bundeswahlleiter.de.

Note: 1965-87 Western Germany; 1990-2009 unified Germany.

a. The figures report the joint result of the Green Party and Alliance90/the Greens, which later merged. In 1990, only the East German Alliance passed the threshold in the eastern Länder; the threshold was applied separately for the two regions in the 1990 election.

After the social democrats engaged in comprehensive welfare state reforms in their second electoral term, support for the party declined considerably. This trend continued under the 2005-09 Grand Coalition, with 
the party receiving fewer than one out of four votes in the federal election in 2009. By contrast, the vote shares for the Left Party clearly increased during this period. For the first time since unification, the SPD's left-wing challenger easily passed the threshold for parliamentary representation; former election nights had been nail-biters for the party. The party's predecessor, the PDS, had been electorally marginalised, struggling to pass the 5 per cent threshold and never gaining a foothold among the western electorate or on the national level. ${ }^{6}$ This puzzle has to be seen in light of the substance of the welfare state reforms. The following sections examine the reforms of the red-green government with respect to the decommodification framework and outline the party competition in this period.

\subsection{Welfare state reforms in Germany and their political context, 1998- 2009}

The German welfare state is typically seen as the archetype of the Bismarckian welfare state. The welfare state's core schemes are financed by social insurance rates, benefits are earnings-related and eligibility is coupled to a sufficient employment record. Unemployment insurance originally consisted of two tiers. The first tier was the contribution-financed Arbeitslosengeld, which had a replacement rate of around 67 per cent and was paid for up to 32 months. The second tier was the tax-financed and means-tested Arbeitslosenhilfe, which had a replacement rate of about 58 per cent (Clasen 2005). In principle it was possible to claim Arbeitslosenhilfe for an unlimited amount of time as long as certain income criteria were fulfilled. Unemployment insurance and the German welfare state in general were not as universal as the social democratic welfare regime, but did secure a relatively high degree of decommodification for the core work force due to the status maintenance principle. As described in Section 5.1, both of the welfare parties, the CDU and the SPD, incorporated these principles ideologically and implemented them in the political praxis during the formative phase of the German welfare state.

Before the red-green government took over, the so-called 'Reformstau' debate was raging in Germany. Reformstau means reform gridlock; that is, the failure to adjust the German welfare state to changed socio-economic circumstances. This, in turn, causes economic problems and fiscal austerity, and has been identified as the major cause of the high unemployment rates in the 1990s (cf. Cox 2001; Harlen 2002; Zohlnhöfer 2004). In the 1994-98 electoral term Chancellor Kohl tried to initiate reforms of the la- 
bour market, the social insurance systems and fiscal policy (Harlen 2002; Zohlnhöfer 2001, 2004). However, not all of the reforms were passed and the unemployment rate remained high. Accordingly, the oppositional SPD with chancellor candidate Schröder launched its electoral campaign for the federal elections in 1998 on these issues, promising to withdraw the Kohl government's reforms, as they were regarded as having adverse social effects. The SPD's victory and the change to a red-green coalition government were credited to the election campaign on social issues and high unemployment (e.g. von Alemann 1999; Feist \& Hofmann 1999).

As promised, the Schröder government suspended Kohl's reforms and introduced minor labour market reforms that were more or less in line with traditional German labour market policies. Moreover, some reforms at the beginning of the electoral term served the demands of the SPD's core clientele and the trade unions (cf. Blancke \& Schmid 2003; Schmidt 2003, 2006; Streeck \& Trampusch 2005). Until 2001, the labour market policy was characterised as 'Politik der ruhigen Hand' (literally: policy of the steady hand), as the Schröder government abstained from controversial labour market reform proposals between 1991 and 2001 (e.g. Blancke \& Schmid 2003: 225). In general, the literature argues that there were moderate welfare reforms during the 1998-2002 election term, but they failed to produce any effects and were largely tailored to the redgreen government's re-election in the 2002 federal election (cf. Blancke \& Schmid 2003; Schmidt 2003; Camerra-Rowe 2004; Zohlnhöfer 2004; Streeck \& Trampusch 2005). The only notable exceptions were the JobAQTIV legislation and the Riester pension reform. ${ }^{7}$

The Job-AQTIV legislation was proposed by the Schröder government in 2001 and came into effect on 1 January 2002 (Blancke \& Schmid 2003: 219). The package reformed the ALMPs by extending qualification and training programmes. For instance, the law introduced wage subsidies for employers who let employees participate in qualification programmes. However, the Job-AQTIV package was not seen as an outright break with the SPD's social policy principles, as it did not tighten eligibility criteria or entitlements for the workforce, nor did it imply any benefit cuts (Blancke \& Schmid 2003: 226).

The second important reform of Schröder's first cabinet was the introduction of a voluntarily-funded private old-age provision scheme (Riester-Rente). Aimed at stabilising non-wage labour costs, the Riester-Rente decreased the future lower replacement rate of the ordinary state pension (from 70 to 64 per cent in 2030), but compensated this with a heavily state-subsidised, funded top-up on the ordinary pension to be built up 
separately from the old age pension insurance (see Leibfried \& Obinger 2003: 212f; Schmidt 2003: 247ff for descriptions of this reform). This was seen as being at odds with the SPD's traditional social policy aspirations, as well as the existing pension policies in Germany, since the state pension was at least partly replaced by a private and capital-funded pension topup, violating the principle of equal contribution rates for employers and employees (Schmidt 2003: 247ff, 2006: 145; Clasen 2005: 114). ${ }^{8}$

Summing up the first term of the red-green coalition, in terms of social policy, the Riester-Rente was the only break with the decommodification principle or other traditional social democratic principles. The government's social policy between 1998 and 2002 is regarded as having benefited the SPD's core constituency (Schmidt 2003: 254ff). ${ }^{9}$

After its re-election, the SPD was still facing deteriorating economic growth, high unemployment rates, the welfare state's growing fiscal burden and a scandal concerning the Bundesanstalt für Arbeit (Federal Employment Office), leading to defeats in two state elections. ${ }^{10}$ This was the trigger for Agenda 2010, a highly controversial reform programme presented on 14 March 2003 in the Bundestag by Chancellor Schröder.

Agenda 2010 represented a clear policy change, as it announced several significant welfare reforms, especially of the labour market (Camerra-Rowe 2004; Zohlnhöfer 2004; Clasen 2005; Streeck \& Trampusch 2005; Debus 2008). Consequently, welfare issues and attitudes towards reforms increasingly polarised the German electorate in general and traditional SPD voters in particular (e.g. Padgett 2005; Schäfer 2007; Picot 2009). In the heated public debate, the reforms were accused of having a negative social impact and producing bitter hardships for the persons concerned (Fleckenstein 2008). The labour market reforms were called Hartz reforms after the former Volkswagen manager Peter Hartz, who advised Chancellor Schröder on labour market issues. The reforms were introduced in four acts (I-IV).

The Hartz I and II reform acts came into effect in January 2003. They introduced temporary work agencies, training vouchers and some new options for business start-ups. In particular, they tightened the definition for suitable work, which meant that the unemployed had to accept job offers that did not match their qualification levels. This implied lower future remunerations. The Hartz III act concerned an internal organisational reform of the federal employment office that does not concern the purposes of the chapter.

The most encompassing and controversial component of Agenda 2010 was the 'Hartz IV' labour market reform. This act was characterised as a 
departure from Germany's approach to unemployment insurance, as well as from traditional social democratic labour market policy (Kemmerling \& Bruttel 2006; Fleckenstein 2008). The unemployment benefit system was reformed since the benefits for the long-term unemployed were no longer dependent on former income, as in the Bismarckian insurance principle (Kemmerling \& Bruttel 2006: 93). The new scheme for the longterm unemployed (Arbeitslosengeld II) consisted of means-tested social assistance with flat-rate benefits. ${ }^{11}$ Compared to previous legislation, this meant lower benefits for most of the former Arbeitslosenhilfe claimants, as the replacement rates decline (Clasen 2005: 75). The eligibility period for short-term unemployed benefits was also limited to one year (previously up to 32 months). ${ }^{12}$

The reform also increased the conditionality of the unemployment benefits significantly. Job suitability criteria were further tightened for ALG II-claimants who de facto had to accept any legal job offered, regardless of the wage-level (ibid). This was accompanied by harsher obligations to participate in job-search activities and training programmes, an approach that especially targeted those unemployed who were under 25 years of age. The Hartz reforms in general also implemented more intense activation measures to increase the effective labour market supply (Kemmerling \& Bruttel 2006). Moreover, market mechanisms and contractingout were used as instruments to enhance job-seeking activities. Table 5.3 summarises the effect of the labour market reforms on the decommodification of labour using Clasen \& Clegg's framework.

The social policy of the Grand Coalition also needs some attention, particularly with respect to the Hartz reforms and the electoral prospects of the SPD and the Left Party. The 2005 federal election saw the replacement of the red-green coalition with a Grand Coalition consisting of the CDU/CSU and the SPD. Essentially, the Grand Coalition adhered to the red-green government's labour market reforms, with some minor changes (Dümig 2010, Menz 2010). Some aspects of the reforms, such as the merger of the Arbeitslosenhilfe and the Sozialhilfe, now unfolded their effects. Persons with longer spells of unemployment were now increasingly affected by the Hartz-IV-reform that was passed one and half years before the early elections in 2005 . By 2005 , the 12 - to 18 -month period of income-related ALG I had passed for those persons concerned, and they were transferred to the flat-rate ALG II. During the incumbency of the Grand Coalition, a sizable number of unemployed thus experienced a loss of income, since their benefits had been decoupled from former earnings. 
Moreover, the Grand Coalition implemented a pension reform programme that increased the statutory retirement age from 65 to 67 (see Schmidt 2010: 310ff). This reform was highly unpopular and was said to imply a lower pension for many wage-earners, as they could not be expected to reach 67 years effectively to qualify for the full pension amount in the statutory pension scheme. Accordingly, while still mobilising against the labour market reforms, the Left Party used the pension reform to attack the SPD and to mobilise new voters.

The overview in Table 5.3 demonstrates that the reforms introduced tighter eligibility criteria, which is not in line with Esping-Andersen's

Table 5.3 Classification of labour market reforms introduced by red-green government, 1998-2005

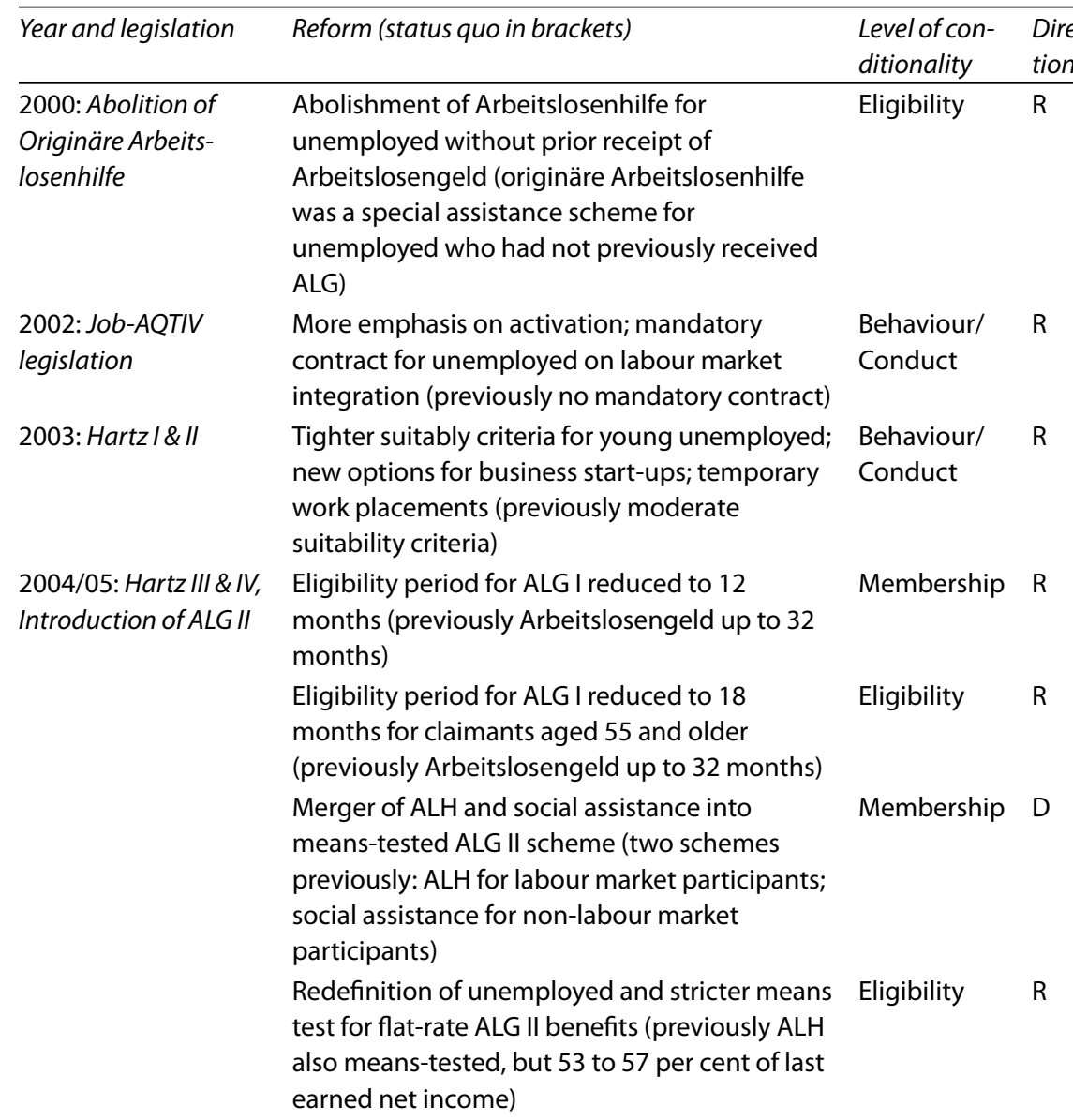


job despite reduced wage level (net earnings

had to exceed benefit level)

Tighter eligibility criteria for unemployed under 25 , eligibility de facto contingent on claimants'

Sources: Clasen (2005); Streeck \& Trampusch (2005); Kemmerling \& Bruttel (2006); Clasen \& Clegg (2007); Fleckenstein (2008).

Notes: the classification of reforms in terms of level of conditionality and direction draws on the scheme of Clasen \& Clegg (2007); R: recommodification, D: decommodification..

claims for universal and unconditional benefits. This is especially true for the reforms implemented after 2002 under the Agenda 2010 label. Similarly, the activation policies are path-breaking, as passive behaviour is now sanctioned. The unemployed are obliged to accept jobs that do not match their skill levels, and are remunerated below average wages and below their previous level of income. Agenda 2010 reforms thus clearly emphasised conditionality in German social policy, since receiving benefits was no longer independent of market exchange, but contingent on a person's willingness to start work or job-training as soon as possible.

Esping-Andersen points to income replacement in benefit schemes as a critical feature of decommodification (1990: 47; see also Lindbom 2001; Scruggs \& Allan 2006). Table 5.4 reports the reforms' consequences on the benefit levels, using the OECD gross employment benefit rate and one indicator for net replacement rates. The OECD data are used, as Scruggs' data series stops in 2003 and thus does not incorporate the effects of the Hartz reforms. Both measures indicate lower replacement rates as a consequence of the reforms. The figures for 2005 and 2007 in Table 5.4 mark the lowest rate for the OECD measure of benefit entitlements beginning in 1961. Table 5.5 demonstrates how much the labour market reforms reduced the replacement rate for the long-term unemployed, as the rate decreased by about 20 percentage points (using a single person with an average wage as an example). Hence, the reforms were responsible for lower replacement rates.

In sum, the reforms tightened eligibility for benefits, introduced less generous benefits accompanied by lower replacement rates, and active labour market polices conditioned access to unemployment benefits by 


\begin{tabular}{lllllllllll}
\hline & 1989 & 1991 & 1993 & 1995 & 1997 & 1999 & 2001 & 2003 & 2005 & 2007 \\
\hline $\begin{array}{l}\text { OECD summary } \\
\text { measure }\end{array}$ & 28 & 29 & 28 & 26 & 26 & 27 & 29 & 29 & 24 & 24 \\
\hline & & $1997^{\mathrm{a}}$ & 2001 & 2002 & 2003 & 2004 & 2005 & 2006 & 2007 \\
\hline $\begin{array}{l}\text { Net replacement } \\
\text { rate }\end{array}$ & 54 & 54 & 54 & 54 & 54 & 36 & 35 & 34 \\
\hline
\end{tabular}

Source: Summary measure: OECD (2010a). Net replacement rate for 1997: OECD (1999), for 2001-07: OECD (2010b).

Notes: The OECD summary measure is defined as the average of the gross unemployment benefit replacement rates for two earnings levels, three family situations and three durations of unemployment. The net replacement rate for the long-term unemployed is the compensation for a long-term unemployed single person with 100 per cent of an average wage earner 19972007.

a. The 1997 figures are not based on the average wage earner, but on the 100 per cent average production worker. The 1997 figures are thus not directly comparable, as the OECD changed the definition of the net replacement rate. Bold figures represent post-reform years.

compulsory participation. Thus, the qualitative and the quantitative measures provide strong evidence that the reforms of the SPD-led government mark a departure from the social democratic policy goals that traditionally tied it to its core constituency. The labour market reforms substituted decommodification policies for conditionality principles, violating Esping-Andersen's argument about unconditional eligibility for benefits with a high replacement rate (1990: 47). As argued above, this threw the party's alignment with its core constituency into question. However, as claimed in Chapter 2, the actual effects of the reforms were contingent on the party system and the presence of particular competitors, to which I now turn.

\subsection{Party competition on welfare state reforms in Germany, 1998-2009}

After the red-green government came into office in 1998, the German party system consisted of four parties on the national level (SPD, CDU/CSU, Greens and FDP). With the PDS, a regional party representing Eastern Germany, ${ }^{13}$ it has been portrayed as a 'fluid five party system' (Niedermayer 2002, 2003, 2006). Five parties were represented in the Bundestag, but the competition differed by region, as the PDS only gained parliamentary representation thanks to its post-communist strongholds in Eastern 
Germany. By contrast, the FDP and the Greens had their strongholds in Western Germany (cf. also Wessels 2004: 58ff). This implied that not each of the three smaller parties (FDP, Greens, PDS) was competitive in a particular region, leading to three- or four-party systems on the regional level and a five-party system in the Bundestag between 1990 and 2002. Concerning the framework on challenger parties for the reform-minded SPD after 1998, two parties should be discussed as competitors, as outlined in Chapter 2: the Christian Democrats (CDU/CSU) and the left-socialist PDS, which later became the Left Party. Party competition in general had been predominantly structured around the socio-economic dimension, especially after the SPD's policy change in the aftermath of the 2002 federal election (Wessels 2004; Schäfer 2007). In contrast to many neighbouring countries, there was no party of the far or new right that constituted a nationwide and dangerous challenger for the SPD at that time (Dolezal 2008).

The CDU/CSU is traditionally Germany's second big welfare-state party and has accordingly been a credible defender of the welfare state (van Kersbergen 1995; Schmidt 2006). In principle, the CDU/CSU represents the type of mainstream party that I have identified as a possible winner from Third Way reforms, if the party moves towards the political preferences of social democratic core constituents. However, the policy of the Christian democrats during the period under review requires some discussion. As mentioned, the CDU/CSU was replaced by the SPD as the main government party in 1998, due to dissatisfaction, amongst other things, with some retrenchment measures implemented in 1996-97. In opposition, the party increasingly developed a market-liberal agenda, especially during the second term of the SPD-led government (2002-05) (e.g. Kornelius \& Roth 2007).

In contrast to this ideological repositioning, the CDU/CSU tried to exploit the deteriorating economic situation during Schröder's first term, particularly the high unemployment rates, and criticised the erratic policy of the government. This benefited the Christian democrats, who won several state elections after 1998. However, the credibility of the CDU/CSU in terms of attracting SPD's rank and file could be expected to be limited in the long run. Moreover, during the election campaign that followed their own welfare state reforms, beginning in 2004, the SPD used the expectation that a CDU/CSU-led government would undertake even more radical reforms as a threat to avoid losses to their Christian democratic opponent (cf. Jesse 2006: 24). ${ }^{14}$ The CDU/CSU also had dirty hands in social policy, as the party cooperated with the red-green government to implement parts 
of the Hartz reforms, the SPD and the Greens having lost their majority in the Bundesrat in 1999. Hence, I would not expect the Christian democrats to make lasting inroads into the social democratic core constituency as a consequence of the SPD's policy change. One effect might be temporary gains for the party in 2002, but, like the SPD, the CDU/CSU had a reform agenda and dirty hands in social policy.

The real challenge for the SPD after the reforms should be the presence of a nationwide left-socialist party, the Left Party. During the first term and the beginning of the second term, the SPD was only challenged by the PDS in the eastern Länder, but not at the national level. The leftwing PDS did not gain a foothold in the western part of Germany and was dependent on its electoral success in the new Länder to gain seats and a parliamentary group in the Bundestag (e.g. Wessels 2004; Patton 2006; Olsen 2007; Picot 2009). In the 2002 federal election, the PDS did not pass the 5 per cent threshold and only won two constituencies in the eastern part of Germany, and thus failed to enter parliament with a parliamentary group. The party was completely marginalised, with only two seats in the Bundestag gained in constituencies in Berlin and no parliamentary representation in western states. ${ }^{15}$

The challenge for the SPD from the left became serious after Agenda 2010. The PDS began to mobilise against the reforms to attract dissatisfied voters in the new Länder, as the reforms were said to harm East Germans in particular. In the western part, one particular consequence was the formation of the WASG (Wahlalternative Arbeit und Soziale Gerechtigkeit), a political group consisting of SPD dissidents and union members opposing the reforms. After having run its own party list in the state election in North Rhine Westphalia but failing to pass the 5 per cent threshold, the WASG decided to join forces with the PDS in view of the early Bundestagswahl in September 2005. ${ }^{16}$ This led to the formation of the Linkspartei (Left Party), a party presenting itself as the 'real' anti-reform welfare party and the clear left-wing alternative (Patton 2006; Olsen 2007). Moreover, former SPD chairman Oskar Lafontaine joined the new party and became one of its chairmen. The Left Party now tried to take advantage of the reforms; it portrayed itself as a defender of the welfare state and fiercely attacked the SPD for its path-breaking reforms, as well as accusing all four other parties of being 'parties of social coldness' (Der Spiegel, 17 July 2005). The party did not have dirty hands, as its previous marginalisation had kept it out of social policy legislation at the federal level. The PDS is a good example of the type of left-socialist challenger identified in Chapter 2. I would expect a realignment of social democratic core constituents with 
the Left Party in 2005, since this party was a credible competitor reflecting the social policy preferences of social democratic core voters. I would also expect a corroboration of the realignment with the 2009 election, since the SPD adhered to its reforms in the Grand Coalition (2005-2009) and was the driving force for the pension reforms in 2007, which raised the statutory pension age to 67 (see Schmidt 2010: 310ff). This should have further benefited the Left Party, which was the only party that seriously attacked this reform and the unfolding of the Hartz reforms during this period.

I would not expect other parties to benefit from the SPD's policy change in terms of votes from the social democratic core constituency. The FDP held distinct market liberal views during the period under review and demanded far-reaching reforms to the German welfare state. The Greens held libertarian views on socio-cultural issues, against the respective preferences of social democratic core constituents (Schäfer 2007). Although the party is generally placed on the left, it had dirty hands due to its involvement in the implementation of Agenda 2010 and the Hartz reforms in the red-green coalition. Furthermore, as argued in Chapter 2, there was no challenge from the right in Germany. Authoritarian right-wing parties were marginalised throughout the period under review, and none came even close to the 5 per cent threshold in the elections after $1994 .{ }^{17}$ There had been occasional gains for the extremist DVU and NPD in state elections, but due to the parties' ambivalent relationship with the national socialist legacy and their suspected anti-constitutional programmatic stance, they did not present a serious challenge to the SPD or other established parties in elections for the Bundestag. The NPD was even threatened with a ban by the Federal Court of Justice in 2001, on the grounds that the party's programme and behaviour were said to be anti-constitutional.

In sum, my expectation for the case of Germany would be a realignment of social democratic core constituents with the Left Party after the path-breaking social policy reforms implemented by the SPD under Agenda 2010. I would not expect other competitors to make systematic gains among the SPD's rank and file.

\subsection{Data and variables}

The data for the analysis of the 2002 and 2005 elections stem from the German National Elections studies and the Politbarometer surveys. The election studies are only used for the descriptive analysis to calculate party shares, whereas the Politbarometer is used in both the descrip- 
tive and the statistical analysis, as it consists of several items measuring public attitudes towards the reforms quite intuitively after 2002. One item asks the respondents directly about their feelings towards the welfare state reforms implemented under the Schröder government, and is thus preferable to recent German election studies with inferior variables.

In the descriptive part, I used two items from the Politbarometer capturing the respondents' attitudes towards proposed reforms, that is, the reforms announced by Schröder in 2003 under Agenda 2010. One is a general assessment of the reforms, the other concerns the cuts in employment benefits as a more concrete proposal. I also used three items from the 2005 Politbarometer survey asking people about their feelings regarding the reforms implemented after 2003. Again, one item taps into the general attitude towards the reforms (right or wrong); the second item asks about the assessment of the cuts to unemployment benefits as a consequence of the Hartz reforms; the third item measures opinions on tighter job suitability criteria, another effect of the labour market reforms as outlined in Section 5.3. ${ }^{18}$

The German Longitudinal Election Study was used for the analysis of the 2009 election. This study consists of three items asking the respondents whether the Hartz reforms, social policy and social justice issues had been the reason for the respondent's vote choice in 2009. The three items were merged into one index measuring whether these matters influenced the voters' decision. This allowed me to examine whether the SPD has lost further voters to the Left Party due to social policy and labour market reforms, and whether voters from the social democratic core constituency stuck to the Left Party in 2009. In this respect, the investigation of the 2009 election taps into the problem of whether the 2005 realignment of SPD voters has been consolidated, and whether there have been further electoral repercussions of the reforms under social democratic governments.

The statistical analysis uses vote intention rather than party choice in the last election, as the survey consisting of the respective items on the assessment of the performance of the Schröder government and attitudes towards the welfare state reforms was conducted prior to the 2002 and 2005 elections. The categories are 1 'SPD', 2 'CD/CSU', 3 'Greens', 4 'FDP', 5 'PDS resp. Left Party' and 6 'Non-voting' (7 for 'minor parties' if applicable). The variables on voter groups are operationalised according to the principles set out in the previous two chapters. 


\subsection{Results}

Attitudes towards reform proposals and actual reforms

I first analyse the public perception of the labour market reforms to be implemented by Schröder's government in its second term. The 2003 and 2005 Politbarometer surveys asked respondents about their feelings regarding the reform proposals announced by Schröder under Agenda 2010, and their attitudes towards the actual reforms and some of the measures implemented. The items capture attitudes before the reforms were implemented and after they became effective.

Table 5.5 shows that the proposals (2003) as well as the actual reforms (2005) were met with approval among the non-core constituency, whereas social democratic core voters were much more sceptical about these policies. A plurality of core constituents found the proposals too far-reaching and assessed the reforms as negative, whereas the opposite was true for the other voters on the first and third item in Table 5.5. In a similar fashion, lower unemployment benefits were met with significantly more approval among the non-core constituency than in the core constituency. The same was true for tighter job suitability criteria, even though both groups generally had a more positive attitude here. Keeping in mind from Section 5.3 that these reforms tightened eligibility criteria, emphasised conditionality and reduced benefits, the attitudes reported in Table 5.5 correspond to the theoretical expectation that the social democratic core constituency would oppose recommodification. Given the negative feelings among its core constituency and the fact that the SPD implemented these reforms after 2003, one would expect the party to face a considerable electoral risk.

Table 5.6 reports the party shares for the core and non-core constituency when the SPD was in government between 1998 and 2009. The SPD's share among its core voters drops by 10 percentage points between 1998 and 2005. Surprisingly, the decline is larger between 1998 and 2002 than four years later. One reason could be that the two election studies used for 2002 and 2005 generally do not match the actual election results when it comes to the shares of the two larger parties. However, taking the result for the recent 2009 federal election, it becomes clear that the SPD lost a considerable share of its core constituency after the party gained office with a Third Way agenda. The vote shares of the SPD were halved between Schröder gaining office in 1998 and 2009. 
Table 5.5 Attitudes towards labour market reform proposals by voter group, percentage points

\begin{tabular}{|c|c|c|c|c|}
\hline \multirow[b]{2}{*}{ Voter group } & \multicolumn{4}{|c|}{$\begin{array}{l}\text { Attitude towards Schröder's reform proposals (AGENDA 2010), } \\
\qquad 2003 \text { [V192] }\end{array}$} \\
\hline & Too far-reaching & Fair & Not sufficient & Total \\
\hline Non-core constituency & 28.8 & 23.3 & 48.0 & 100 \\
\hline Core constituency & 42.8 & 22.4 & 34.8 & 100 \\
\hline \multirow[t]{3}{*}{$\mathrm{N}=3,657$} & & & Chi': 86.1 & $\mathrm{P}<.000$ \\
\hline & \multicolumn{4}{|c|}{ Attitude towards present reforms, 2005 [V236] } \\
\hline & Right & & Wrong & Total \\
\hline Non-core constituency & 55.7 & & 44.3 & 100 \\
\hline Core constituency & 37.1 & & 62.9 & 100 \\
\hline \multirow[t]{3}{*}{$\mathrm{N}=2,753$} & & & Chi': 91.4 & $\mathrm{P}<.000$ \\
\hline & \multicolumn{4}{|c|}{$\begin{array}{l}\text { Assessment of reduction of unemployment benefits } \\
\text { (Arbeitslosengeld II), } 2005 \text { [V239] }\end{array}$} \\
\hline & Right & & Wrong & Total \\
\hline Non-core constituency & 60.4 & & 39.6 & 100 \\
\hline Core constituency & 49.4 & & 50.6 & 100 \\
\hline \multirow[t]{3}{*}{$\mathrm{N}=1,377$} & & & Chi': 16.0 & $\mathrm{P}<.00$ \\
\hline & \multicolumn{4}{|c|}{$\begin{array}{c}\text { Assessment of tighter job suitability criteria for long-term } \\
\text { unemployed, } 2005 \text { [V240] }\end{array}$} \\
\hline & Right & & Wrong & Total \\
\hline Non-core constituency & 77.6 & & 22.4 & 100 \\
\hline Core constituency & 65.3 & & 34.7 & 100 \\
\hline $\mathrm{N}=1,460$ & & & $\mathrm{Chi}^{2}: 26.9$ & $\mathrm{P}<.000$ \\
\hline
\end{tabular}

Source: Own calculations based on Politbarometer 2003 and 2005.

The PDS received about 4 per cent of the votes among the social democratic core constituency before 2005 and its successor Left Party increased its share to 12 per cent, which is in line with the expected direction of electoral change for this left-wing challenger. The 2009 election also corroborates the realignment of the 2005 election, where former SPD core voters shifted to the left competitor. The Christian democrats seemed to benefit in 2002 among this voter segment, but fell below their 1998 share in the 2005 and 2009 elections. This resembles the expected lack of credibility due to the Christian democrats' reform agenda after 2002. To match the reported shares from the election studies with the data used for the analysis, I calculated the support for the SPD among its core constituency with the Politbarometer surveys. 


\begin{tabular}{lrrrr}
\hline Core constituency & 1998 & 2002 & 2005 & 2009 \\
\hline SPD & 45.9 & 39.5 & 36.1 & 20.0 \\
CDU/CSU & 39.5 & 33.9 & 24.9 & 21.0 \\
Liberals & 1.4 & 6.2 & 6.4 & 10.9 \\
Greens & 3.1 & 4.4 & 7.6 & 8.8 \\
PDS/Left Party & 4.4 & 3.6 & 8.5 & 12.1 \\
Non-voters & 12.0 & 10.5 & 12.5 & 25.0 \\
\hline Non-core constituency & & & & \\
\hline SPD & 38.4 & 33.4 & 32.1 & 17.3 \\
CDU/CSU & 35.0 & 41.0 & 27.2 & 25.2 \\
Liberals & 6.6 & 7.2 & 10.8 & 17.6 \\
Greens & 8.7 & 11.2 & 11.8 & 15.5 \\
PDS/Left Party & 4.5 & 3.5 & 8.9 & 9.1 \\
Non-voters & 4.4 & 2.0 & 7.3 & 13.5 \\
\hline Source:German Election Studis
\end{tabular}

Source: German Election Studies 1997-2005 and German Longitudinal Election Study 2009.

Figures do not always add up to 100 per cent due to rounding and omission of minor parties.

Figure 5.1 shows the vote intention for the SPD from 1998 to 2007. It becomes obvious that Schröder's election victory in 1998 rested upon a strong backing among the core constituency, as mentioned in Section 5.2. The party's share stayed at around 40 per cent before the 2002 election, when it showed the first signs of decline. The Agenda 2010 was proposed shortly after the 2002 election, also a time of strong decline for the SPD. After implementing the reforms in 2003 and 2004, the party hit the bottom as their core constituency support fell below 30 per cent. In late 2004 and up to the 2005 election, the party regained some strength, but never recovered to previous levels of support. Briefly stated, the SPD's share among its rank and file always exceeded 35 per cent until the 2002 election, but dropped below this benchmark with the announcement of Agenda 2010 and the implementation of the reforms in the following months. Thus, although the election studies do report a different pattern of decline, the support in the polls clearly suggests permanently weakened backing for the SPD among its core constituency due to the party's reformist agenda after the 2002 election. ${ }^{19}$ The next step is to model the anticipated losses of the SPD and the expected realignment of social democratic core constituents with the Left Party in 2005. 


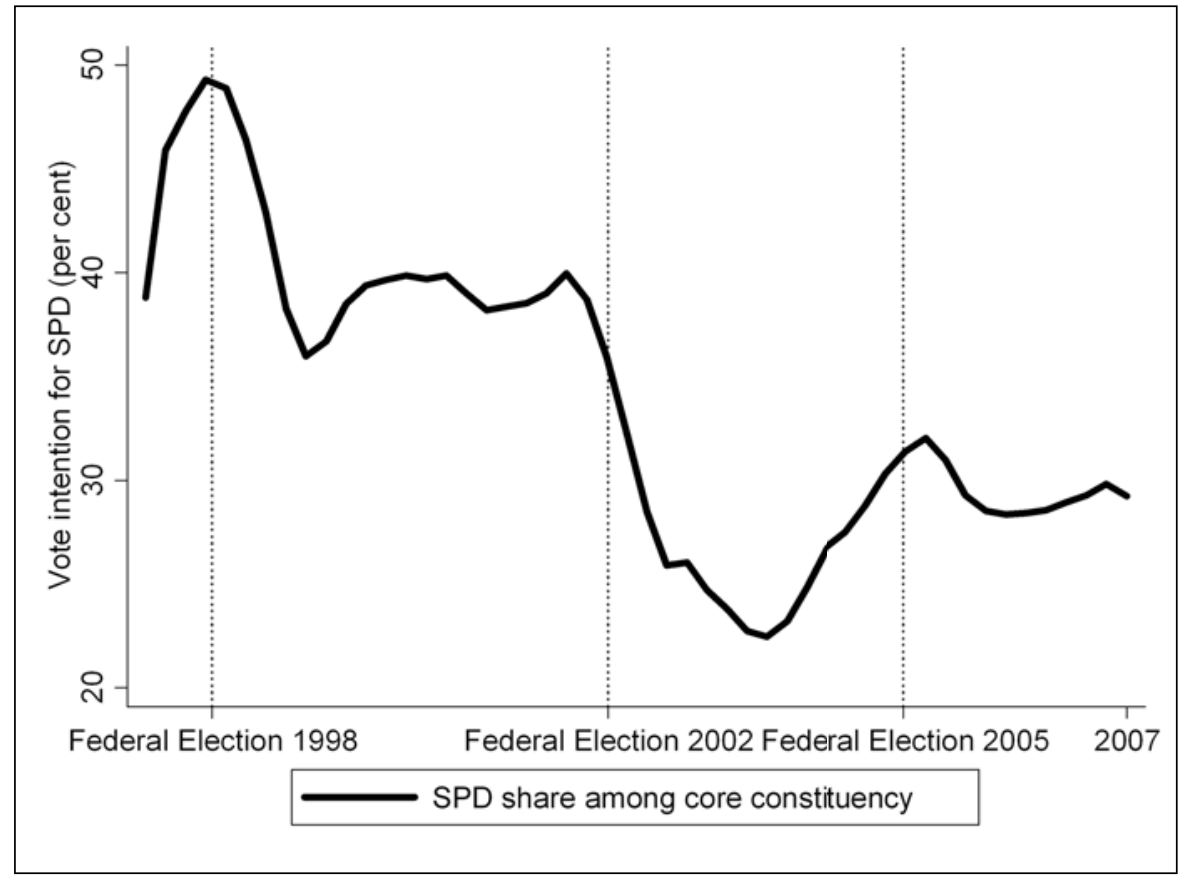

Source: Politbarometer 1998-2007, own calculation, line smoothed.

First red-green cabinet, 1998-2002

As discussed above, with the exception of the Job-AQTIV legislation and the Riester reform, the SPD refrained from implementing major reforms during the first term of the red-green government. However, the Schröder government was dealing with high unemployment and a deteriorating economic situation, and consequently faced public dissatisfaction. As neither data set includes a variable that taps into social policy attitudes, I had to use a variable measuring satisfaction with the government's performance.

Table 5.7 reports predicted probabilities obtained from a multinomial logistic regression model. The figures demonstrate that dissatisfaction with the SPD's performance led to a significantly weaker result among the party's core constituency in 2002. Here the two centre-right opposition parties, the CDU/CSU and the FDP, gained significantly compared to the group of satisfied core constituents. The same held true for minor parties and non-voting, although non-voting was not as pronounced as in the case of Britain. It was the largest competitor, the Christian Democrats, 
Table 5.7 Predicted probabilities of vote choice among aligned core constituency by perception of SPD, 2002

\begin{tabular}{lcc}
\hline & \multicolumn{2}{c}{ Satisfied with performance of government } \\
Estimated vote intention 2002 & Good & Bad \\
\hline SPD & 77.6 & $36.8^{*}$ \\
CDU/CSU & 6.3 & $29.1^{*}$ \\
Greens & 3.3 & 2.1 \\
Liberals & 2.4 & $7.2 !$ \\
PDS & 6.0 & 8.5 \\
Other parties & 1.0 & $5.0^{*}$ \\
Non-voting & 3.6 & $12.7^{*}$ \\
Overall & 100 & 100 \\
\hline Source: Predicted probabilities obtained from multinomial logistic regression model using \\
Clarify. & \\
Notes: The number of simulations to obtain the probabilities was set to $1,000 . ! \mathrm{p}<.10 ;{ }^{*} \mathrm{p}<.05$.
\end{tabular}

that attracted most disappointed social democratic core voters after the first term of the red-green coalition. The SPD's left-wing challenger PDS did not significantly benefit from the dissatisfaction with the government, which is a sign that the realignment was not produced in 2002 given the lack of encompassing reforms leading to recommodification. This election was also a disaster for the PDS, which failed to pass the electoral threshold or to win even three single member constituencies, as it had done in 1998. Keep in mind, however, that the social democrats survived the election with a minor loss among both the electorate and their constituency. Moreover, the measure used is a more general item capturing the assessment of the government rather than social policy attitudes. The next step is to look at the electoral effects of the SPD's engagement in a significant policy change after this election, where one would expect major electoral change.

\section{Second red-green cabinet 2002-05}

We would expect the analysis of the 2005 election to show the realignment of social democratic core constituents with the Left Party, following the SPD's engagement in path-breaking labour market reforms in the second term of the red-green cabinet. The Politbarometer 2005 survey includes an item that directly asks the respondents to assess the reforms 
(already used in Table 5.5). Unfortunately, this question was posed to the respondents before the 2005 election, so I had to use vote intention rather than vote decision. This shortcoming is tolerated on the basis that the item on people's feelings about the reforms is by far the best available measure, given the purposes of this chapter. Table 5.8 shows the predicted probabilities for vote intention of social democratic core constituents, contingent on their assessment of the reforms.

Table 5.8 Predicted probabilities of vote choice among voter groups by attitudes towards reforms, 2005

\begin{tabular}{lcc}
\hline & \multicolumn{2}{c}{ Assessment of welfare state reforms: core constituency } \\
Estimated vote intention 2005 & Good & Bad \\
\hline SPD & 71.7 & $45.5^{*}$ \\
CDU/CSU & 10.0 & 16.3 \\
Greens & 4.2 & 2.9 \\
Liberals & 1.7 & 2.0 \\
Left Party & 6.0 & $16.2^{*}$ \\
Non-voting & 5.7 & $17.0^{*}$ \\
Overall & 100 & 100 \\
\hline & Assessment of welfare state reforms: non-core \\
& & constituency \\
Estimated vote intention 2005 & Good & Bad \\
\hline SPD & 33.8 & $17.0^{*}$ \\
CDU/CSU & 36.9 & $48.0^{*}$ \\
Greens & 12.5 & $6.8^{*}$ \\
Liberals & 6.6 & 5.8 \\
Left Party & 4.4 & $8.6^{*}$ \\
Non-voting & 5.7 & $13.6^{*}$ \\
Overall & 100 & 100 \\
\hline SourcePredict & &
\end{tabular}

Source: Predicted probabilities obtained from multinomial logistic regression model using Clarify.

Notes: The number of simulations to obtain the probabilities was set to $1,000 . ! p<.10 ;{ }^{*} p<.05$.

The results correspond with the theoretical expectations and the contextual conditions mentioned above. The SPD lost significantly among aligned core constituents who were dissatisfied with the reforms implemented after 2002; the party was not even able to mobilise every second 
voter from this segment in 2005 . There were only two clear alternatives to the groups approving the reforms and those opposing the reforms: switching to the Left Party or abstention. The Christian democrats were not able to mobilise former social democratic core constituents; the differences were not significant, which fits the claims made above. The CDU/ CSU did not present a credible alternative, given its own reform agenda and involvement in the Hartz reforms. The same was true for the Liberals and the SPD's coalition partner, the Greens.

As hypothesised, the Left Party benefited significantly from the core constituency's opposition to the reforms. The share among reform-minded core constituents equalled the share for the 2002 election. However, the party won reform-averse core voters from the social democrats in the 2005 election. This confirms the expected logic of electoral change under the red-green cabinet and the electoral threat of a left-wing challenger for reform-minded social democrats.

By contrast, disaffected core voters abstained from voting for the SPD in 2005 and dealigned into the non-voter camp. The difference is smaller than that in the British case discussed in the previous chapter, but nonetheless significant. On the other hand, German voters had a left-wing alternative to reform-minded social democrats. The differences in party shares between reform-minded and reform-averse for the non-core constituency are generally small, confirming the claim that the reforms concerned the social democratic core constituency in particular. Nonetheless, there are significant differences for all options except the Liberals. Both coalition partners lost significantly, whereas the Left Party made some gains, though much smaller than in the upper half of the table. The party might appeal to reform-averse voters outside the working class constituency. The Left Party also accused the Greens of departing from its distinct left positions in social policies under the red-green coalition (FAZ, 3 July 2005). It is striking that the shares of the SPD and the Greens halved, whereas the Left Party doubled it share. The turn to abstention in this voter group was less pronounced than in the aligned core constituency.

The SPD in the Grand Coalition, 2005-09

The analysis of the 2009 election illustrates the SPD's further decline after the party formed a Grand Coalition with the Christian Democrats, under which the Hartz reforms came into full effect and a pension reform package was passed. The respective items from the German Longitudi- 
nal Election Study 2009 asked the respondents why they had voted for a particular party. Using the respective social policy items as outlined in Section 5.5 above, the analysis for 2009 has two objectives. First, I examine whether the SPD lost further votes due to its social and labour market policy. Second, we can control for whether Left Party voters from 2009 stuck to the party and whether social policy played a role in the suspected corroboration of the Left Party realignment. Table 5.9 shows the predicted probabilities from the respective logistic regression models.

The table's upper half shows that the SPD lost further votes to the Left Party in 2009 due to the labour market reforms and social policy issue, as the figures can be significantly distinguished. The Left Party was the only party that would benefit if core voters were to shift away from the SPD in the 2009 federal election due to social and labour market policies. Thus, the expected dealignment of SPD core voters was lasting and the Left Party not only consolidated the 2005 realignment, but also won even more social democratic core votes due to the welfare state reforms.

The table's lower half illustrates that the Left Party kept social democratic core voters concerned about these issues, even though, surprisingly, there is no significant distinction between the left-hand and right-hand column here. The SPD was only able to recapture a few core voters from its left-wing opponent. Nine out of ten Left Party voters from the social democratic core constituency stuck to the party if their vote decision was based on social policy issues. This effect is quite remarkable, since it has traditionally been the SPD that has mobilised German voters on social policy grounds.

Table 5.9 Predicted probabilities of vote choice among voter groups by attitudes towards reforms, 2009

Social policy and labour market reforms reason for vote choice: aligned core constituency

\begin{tabular}{lcc} 
Estimated vote choice 2009 & Not named & Named \\
\hline SPD & 49.2 & 56.8 \\
CDU/CSU & 7.6 & $0.2^{*}$ \\
Greens & 6.7 & 2.7 \\
Liberals & 4.5 & 0.9 \\
Left Party & 13.5 & $39.4^{*}$ \\
Non-voting & 18.6 & $0.0^{\text {a }}$ \\
Overall & 100 & 100 \\
\hline
\end{tabular}




\begin{tabular}{lcc} 
Estimated vote choice 2009 & Not named & Named \\
\hline SPD & 13.4 & 9.3 \\
CDU/CSU & 24.4 & $0.3^{*}$ \\
Greens & 0.0 & 0.0 \\
Liberals & 0.0 & 0.0 \\
Left Party & 56.0 & 90.4 \\
Non-voting & 6.3 & $0.0 \mathrm{a}$ \\
Overall & 100 & 100
\end{tabular}

Source: Predicted probabilities obtained from multinomial logistic regression model using Clarify.

Notes: The number of simulations to obtain the probabilities was set to $1,000$. ! $p<.10 ;{ }^{*} p<.05$. a: The dataset's respective items only gave the option of marking a party but not abstention if one named a particular reason for his/her vote choice. This explains the probability of zero for abstention in the right-hand side of the table.

In sum, this last empirical section corroborated the chapter's main finding of a realignment of SPD core constituents towards the Left Party. Moreover, four years later, the SPD's adherence to the Hartz reforms under the Grand Coalition and the pension reform programme as another likely catalyst not only consolidated the realignment, but also even strengthened it. The reforms' electoral consequences were thus lasting: the SPD did not recover after the 2005 federal election and the Left Party indeed forged a realignment of social democratic core voters in the same election. Another development was the abstention of many SPD core voters in 2009, in addition to the losses to the Left Party. This resembles some of the findings from the British case, where we saw a dealignment of social democratic core voters as a consequence of path-breaking welfare state reforms.

\subsection{Conclusion}

The chapter set out to investigate what happens when Third Way social democrats are challenged by a pro-welfare left-socialist party, and thus risk a realignment of their core constituency with the left competitor. This was achieved by analysing the electoral consequences of the welfare state reforms of the red-green government in Germany after 1998. In accordance with the theoretical framework outlined in Chapter 2, the SPD has 
traditionally been able to draw upon the support of a core constituency of workers and lower white collar-employees. In recent decades, the party was committed to decommodifying welfare policies reflecting the core constituency's political preferences. After the SPD reformed the German welfare state, this alignment was thrown into question, as the reforms were characterised as a form of recommodification.

The Left Party emerged as a nationwide left challenger to the SPD as a consequence of the welfare state reforms of the 1998-2005 red-green coalition and the SPD's participation in the Grand Coalition in the following four years. Drawing on the party system framework, I hypothesised a realignment of social democratic core voters to the Left Party, which represented the 'dangerous left competitor' conceptualised in Chapter 2. No other systematic patterns of realignment from or to other parties were expected, as the SPD's traditional competitor on welfare, the mainstream CDU/CSU, had its own reform agenda, and no right-wing social protectionist party played a role in Germany during the period under review.

The results reveal that the Left Party was indeed able to foster a realignment of social democratic core voters in the 2005 federal election, after the SPD had reformed the welfare state with Agenda 2010 and the Hartz reforms. This was a lasting development: the Left Party maintained its strength among the social democratic core voter base and even increased its vote share in the following election in 2009. The Left Party appeared as a new competitor with clean hands in social policy, as the party (like its predecessor, the PDS) had not been involved in the welfare reform legislation after 2002. The party could thus present itself as a credible alternative to reform-averse voters. ${ }^{20}$ Hence, the presence of the Left Party after 2004 and the realignment of social democratic core constituents with this party confirm that after implementing recommodifying reforms, Third Way social democrats face electoral hazards in the form of competition from the hard left. ${ }^{21}$

Despite its traditional welfare party image, the mainstream CDU/CSU was unable to make lasting gains in the social democratic core constituency, given its own reform agenda and the fact that the party had cooperated with the SPD in the Hartz reforms legislation. The party did not make a strategic move to win traditional social democratic voters after their own party had abandoned its social policy agenda. The CDU/CSU benefited from the general dissatisfaction with the Schröder government in 2002, but was unable to capitalise on Schröder's reform agenda later on. This confirms the claim that challengers need to present a credible alternative to mobilise social democratic core constituents. On that ac- 
count, Schröder was even able to use the anticipated reform agenda of a centre-right government as blame-avoidance in the election campaigns in 2002 and 2005 (Jesse 2006: 24). Especially in the latter case, Chancellor Schröder managed to avoid the great disaster predicted by opinion polls in the run-up to the election (Niedermayer 2006: 124; Kornelius \& Roth 2007: 38).

The SPD had no challengers from the far right: only in a couple of state elections were parties on the far right able to pass the electoral thresholds (the DVU in Brandenburg 2004; the NPD in Saxony 2004 and Mecklenburg-West Pomerania 2006) or come close to parliamentary representation (the NPD in Saarland 2004 and Berlin 2006). These parties capitalised on the dissatisfaction with the Hartz reforms, especially Hartz IV, and used social protectionist rhetoric, even though the DVU and NPD are antisystem parties rather than new right parties, as commonly claimed in the literature.

After 2002, the SPD also faced a dealignment of core constituents who longer turned out to vote. As in the British case, the abstention of social democratic core voters practically doubled if we compare the figures for 1998 and 2009 (Table 5.6). However, the dealignment was less pronounced than that which the Labour Party experienced, since turnout remained higher in Germany and the SPD's major problem after the reforms were the lasting losses to the Left Party. Nevertheless, increasing abstention was another sign of the alienating effect of Third Way agendas on ties with the core constituency. Elff's recent analysis (2010) reveals that this political alienation especially concerned social classes that had traditionally been affiliated with the SPD, but that had become disillusioned over the past decade. The result has been lower turnouts and higher vote shares for the Left Party in recent years.

One reason why, after four years of the Grand Coalition, the SPD faced a dealignment of core constituents in 2009, can be found in the party's electoral strategy. Even in view of poor opinion polls, the party and its then candidate for the chancellorship, Frank-Walter Steinmeier, ruled out any coalition or even parliamentary cooperation with the Left Party after the 2009 federal election. This made an SPD-led government, or even any majority left-of-centre government, highly unlikely. Moreover, a sufficient number of SPD sympathisers have been aware of the ineffective strategy of the social democrats that increased the incentives to abstain (Blätte 2010; Egle 2010; Raschke 2010). Moreover, the CDU/CSU based its strategy on this strategic dilemma for the social democrats and tried to avoid any strong polarisation around issues that would benefit the SPD or the 
Left Party; so-called asymmetric demobilisation where a 'boring' electoral campaign would discourage more potential SPD voters than voters preferring a centre-right coalition of the Union and the FDP (Blätte 2010; Jung et al. 2010: 37). Thus, the strategies of the two major parties in 2009 are one likely reason for the dealignment of SPD core voters, who faced no realistic governmental alternative that would match their (social policy) preferences (see Raschke 2010 and Egle 2010 for more extensive discussions).

Another possible reason why not all reform-averse social democratic core constituents turned to the Left Party is this party's ambiguous stance on socio-cultural issues. While it consists of both libertarian and authoritarian politicians, this issue did not play a major role in the election campaigns given the dominance of the socio-cultural dimension. Furthermore, the party still has an ambiguous relationship with the GDR heritage. For some former SPD supporters, the party is unelectable due to the de facto liquidation of the SPD in 1946 in the GDR.

At the time of writing, the partisan realignment and the five-party system have been consolidated, as the results of the 2009 federal election demonstrated. The Left Party has fostered a realignment of social democratic core supporters as a consequence of the welfare state reforms implemented by the SPD. The Left Party is now an established party at the national level, to the left of the SPD. It has won seats in almost all Länder, something that its predecessor the PDS never managed. This remained the case even after the popular chairman and former SPD chairman, Oskar Lafontaine, left federal politics for personal reasons. The Left Party has stabilised at around 10 per cent in the polls, indicating that a pure leadership effect can be ruled out. 


\section{Denmark}

This chapter examines what happens when Third Way social democrats are confronted with a serious challenger on the authoritarian right. Moreover, the chapter analyses the credibility considerations for competitor parties, as mentioned in the theoretical chapter. This will be done by examining the electoral consequences for Danish social democracy (Socialdemokratiet i Danmark, SD) since the mid-199os. Replacing a centre-right government in 1993, Danish social democracy engaged in path-breaking labour market reforms under a Third Way agenda. The SD has traditionally faced a competitor on the Left, the Socialist People's Party (Socialistisk Folkeparti, SF). In addition, it has been challenged by the right-wing Danish People's Party (Dansk Folkeparti, DF) since the mid-199os. The SD's biggest challenger, the mainstream Liberal Party (Venstre), also deserves some attention, as the party has transformed ideologically since 1993 .

The SD was one of the early parties to transform itself under a Third Way agenda in terms of both ideology and policy, after the party regained office in 1993 (Green-Pedersen et al. 2001). It was responsible for three rounds of labour market reforms between 1993 and 2001, reforms that have been identified as path-breaking (Goul Andersen 2002, 2003a). These reforms broke with the decommodification principle, as social security became more conditional and entitlements were tightened under the social democratic government.

After the SD changed its policy under the new leader and then Prime Minister, Poul Nyrup Rasmussen, the party lost votes in the period between 1993 and 2001. It was overtaken by the Liberals in the 2001 election, for the first time in decades. In the same election, the Danish People's Party emerged as a serious right-wing competitor, gaining about one out of eight votes. The case of Denmark makes it possible to examine (1) the potential of a right-wing challenger to foster realignment after recommodifying welfare state reforms and (2) the strategic dilemmas of leftwing competitors. The following expectations will guide the remainder of 
this chapter. First, with the 2001 election, we would expect the right-wing Danish People's Party to foster a realignment of social democratic core constituents, as Danish social democracy had alienated its core constituents with its welfare policy in the 1990 os. Second, we would not expect the Socialist People's Party to be able to capitalise on the social democrats' policy change, as it formed a legislative coalition with the social democratic minority government. Third, the role of the Liberal Party deserves attention, as the party tried to attract social democratic core voters during the 1990 .

\subsection{The social policy of social democracy in Denmark}

In the post-war era, the Danish social democratic party (SD) introduced three party constitutions (SD 1961, 1977, 1992). The party constitutions from 1961 and 1977 contain traditional social democratic commitments to social policy and the welfare state, in line with the theoretical arguments in Chapter 2. At various points, the 1961 and 1977 party constitutions criticise the effects of the pure market allocation of goods and labour. More concretely, they argue that income maintenance in case of accidents, sickness, old age and unemployment ought to be secured through universal social security schemes and should be formulated as a social right (SD 1961, 1977). ${ }^{2}$ Furthermore, both manifestos are committed to solidarity and egalitarianism, to be realised through taxation and wage policy improving the living standards of the less well-off. The 1992 manifesto is still committed to universal social rights, egalitarianism and solidarity, but it departs from the earlier manifesto in that it emphasises individual responsibility and individual duties in the provision of welfare as the party's

principles, and thus indicates the SD's shift towards a Third Way agenda (Petersen 2001: 45; cf. also Christiansen 1994: 97f). In sum, Danish social democracy's programmatic commitments represent Esping-Andersen's argument about decommodifying welfare policies and Huo's conception of traditional social democratic core values. However, the SD's transformation into a Third Way party was already foreshadowed in the 1992 party constitution.

Danish social democracy's social policy record reveals that the party has translated its standpoints on the welfare state into political praxis to a remarkable degree. Danish social democrats were forerunners in establishing a universalistic welfare state with generous social benefits aimed at decommodifying the wage-earner, although in contrast to its 
Swedish and Norwegian sister parties, the SD never had an overall majority. This implied a more pragmatic approach in daily politics, including compromises with other parties in the development of the Danish welfare state (for a critical assessment, see Esping-Andersen 1985: 9off).

In the post-war era, the party came to power in 1953 and formed a minority government that, in 1957, realised one of the most important social policy innovations in the Danish welfare state's history, the universal people's pension (Folkepension). This new tax-financed pension scheme introduced guaranteed minimum benefits to all citizens, as well as higher basic amounts compared to the previous legislation. This is also seen as a first step in the institutionalisation of universal social rights in Denmark (Christensen 1998: 66).

In the 1960s, the social democrats participated in a reform of the health insurance system. Income maintenance in case of sickness was expanded to all wage-earners, general flat-rate sickness allowances were introduced and eligibility criteria for membership in the health insurance system were abolished (Christensen 1998 chap. 5; Petersen 1998: 23off). Further reforms extended the people's pension with an early retirement scheme, an earnings-related supplement (ATP) and more generous benefits. For instance, the replacement rate of unemployment benefits was raised to 80 per cent, and waiting days were abolished.

After the SD lost its majority in 1968, a centre-right government consisting of the Social Liberals, the Conservatives and the Liberals took over. This government replaced private health insurance funds with universal public health insurance financed by taxes and administered by the municipalities (Strukturreform); it went into effect in 1973 (Christensen 1998: chap. 9, 10; Petersen 1998: 292ff; Plovsing 2007: 59f). The shift to universal public health insurance was largely supported by the social democrats. ${ }^{3}$

Returning to power in 1971, the social democrats raised the replacement rates of health insurance and unemployment benefits from 80 to 90 per cent. The maximum benefits were also increased and restrictions concerning the eligibility period, as well as waiting days for manual workers, were abolished (Christensen 1998: chap. 10; Petersen 1998: 301f; Plovsing 2007: 59f). However, due to Denmark's deteriorating economic situation after the first oil crisis in 1973 and the difficult political situation after the earthquake election in the same year, no major social policy innovations took place in the remainder of the 1970 . The only notable exception was the introduction of the early re- 
tirement pension scheme (Efterlønnen) under a grand coalition in 1979 (Green-Pedersen 2002b: 69). Social democratic minority governments remained in power until 1982, when a centre-right coalition government took over.

The new government tried to impose austerity measures, including a freeze on social security benefits. It was fiercely criticised by the SD (see Green-Pedersen 2002a: 115), and the party regained strength among its core supporters (Christiansen 1994: 97f). Despite its criticism of the cuts and the party's clear opposition profile in the 1980s, it took the social democrats until 1993 to regain power, in coalition with the Social Liberals, but with a new stance on welfare, to be discussed below.

Summing up, the SD's ideological commitment to the welfare state and its social policy record match the theoretical arguments on social democracy discussed above. The Danish social democratic party had a strong commitment to decommodifying welfare policies and put this into political praxis to a considerable degree in the period after $1950 .{ }^{4}$ Even though the party was challenged by the SF early on, it pioneered the institutionalisation of universal social rights in the Danish welfare state and was responsible for very generous levels of income maintenance in case of old age, sickness and unemployment. ${ }^{5}$ Since this is in line with Esping-Andersen's decommodification thesis, we would expect the SD to have drawn on the support of particular social classes as the party's core constituency in the second half of the 2oth century.

\subsection{The traditional core constituency of Danish social democracy}

In line with the theoretical propositions outlined in Chapter 2, we can assume that the SD aligned with particular social strata as the party's core constituency. Table 6.1 shows the vote choices among classes conceptualised as the social democratic core constituency after 1973. The table largely confirms the theoretical expectations regarding the core constituents of social democratic parties, as well as the electoral implications of the SD's social policy record presented above. Even though the SD (like other established parties) experienced a crisis with and after the earthquake election in 1973, the party has traditionally enjoyed considerable support among particular voter groups forming the party's core constituency of workers and lower white-collar employees.

The party's support among lower-white collar employees was not as pronounced as among the working class, but the SD could nevertheless draw 
Table 6.1 Party shares for selected parties by selected social classes, Denmark 19732005

\begin{tabular}{cccccccccccccccc}
\hline & \multicolumn{1}{c}{1973} & 1975 & 1977 & 1979 & 1981 & 1984 & 1987 & 1988 & 1990 & 1994 & 1998 & 2001 & 2005 \\
\hline SD & RNM & n.a. & 32 & 39 & 38 & 25 & 25 & 24 & 29 & 36 & 34 & 34 & 27 & 33 \\
& Skilled & 41 & 51 & 59 & 46 & 37 & 45 & 34 & 40 & 55 & 44 & 37 & 34 & 27 \\
& Unskilled & 57 & 45 & 57 & 56 & 59 & 47 & 44 & 44 & 57 & 45 & 44 & 33 & 34 \\
\multirow{4}{*}{ Venstre } & RNM & n.a. & 20 & 7 & 10 & 12 & 11 & 7 & 10 & 13 & 23 & 21 & 38 & 29 \\
& Skilled & 15 & 13 & 4 & 5 & 7 & 6 & 5 & 5 & 5 & 21 & 24 & 19 & 27 \\
& Unskilled & 1 & 15 & 4 & 6 & 10 & 7 & 8 & 8 & 8 & 18 & 20 & 31 & 23 \\
SF & RNM & n.a. & 5 & 9 & 7 & 11 & 22 & 26 & 22 & 13 & 11 & 13 & 7 & 5 \\
& Skilled & 11 & 2 & 12 & 12 & 18 & 23 & 23 & 20 & 2 & 5 & 2 & 5 & 4 \\
& Unskilled & 6 & 3 & 3 & 4 & 8 & 13 & 20 & 19 & 9 & 8 & 10 & 3 & 3 \\
\multirow{4}{*}{ DF } & RNM & - & - & - & - & - & - & - & - & - & - & 5 & 10 & 14 \\
& Skilled & - & - & - & - & - & - & - & - & - & - & 13 & 24 & 21 \\
& Unskilled & - & - & - & - & - & - & - & - & - & - & 6 & 19 & 21 \\
\hline
\end{tabular}

Source: Own calculations based on Danish election studies 1973-2005.

Notes: RNM: Routine non-manual, Skilled: skilled workers, Unskilled: unskilled workers, n.a.: information not available.

on the most support from this class until 1998. As already pointed out by Esping-Andersen (1985), Danish social democracy failed to attract parts of the white-collar electorate due to its pragmatic policymaking style and the presence and electoral appeal of the SF, which attracted parts of the new middle class.

In the mid-1980s, the SF also managed to attract some working-class votes, when both major left parties had been in opposition to the centreright government and mobilised on welfare issues. Afterwards, the SF developed into a more pronounced left-libertarian party mobilising on issues such as minority rights, equal rights and environmental protection, even though the party retained its pro-welfare stance (Arter 2003; Spier \& Wirries 2007).

The SD continued to recover its previous levels of electoral support among the working class until the early 1990s, whereas the SF did not maintain its former level of support (and even lost ground after tolerating the minority government coalition led by the social democrats in the mid1990 os and afterwards). Similar tendencies can be observed for vote shares in general. 
Table 6.2 reveals that the SD typically achieved at least 30 per cent of the votes after the 1973 election and also recovered from a low during the 198 os. However, the striking feature is the decline after 1998 , as the party failed to reach the 30 per cent mark in three consecutive elections. It also lost its position as the strongest party to the Liberals for the first time since 1920. The SF, the SD's main left-wing challenger, was not able to benefit from the Nyrup government's reforms, but gained considerably in the 2007 election under a bourgeois coalition government, something that will be discussed further in the conclusion. The right-wing Danish People's Party emerged with the 1998 election and made its breakthrough in 2001, after the social democratic government had implemented all three rounds of labour market reforms. This development and the electoral change after 1993 must be seen in the general light of the welfare state reforms to be described in the next section.

Table 6.2 Vote shares in Danish general elections, 1973-2007

\begin{tabular}{lrrrrrrrrrrrrrrrr}
\hline & 1973 & 1975 & 1977 & 1979 & 1981 & 1984 & 1987 & 1988 & 1990 & 1994 & 1998 & 2001 & 2005 & 2007 \\
\hline SD & 25.6 & 29.9 & 37.0 & 38.3 & 32.9 & 31.6 & 29.3 & 29.8 & 37.4 & 34.6 & 35.9 & 29.1 & 25.8 & 25.5 \\
Venstre & 12.3 & 23.3 & 12.0 & 12.5 & 11.3 & 12.1 & 10.5 & 11.8 & 15.8 & 23.3 & 24.0 & 31.3 & 29.0 & 26.2 \\
KF & 9.2 & 5.5 & 8.5 & 12.5 & 14.5 & 23.4 & 20.8 & 19.3 & 16.0 & 15.0 & 8.9 & 9.1 & 10.3 & 10.4 \\
RV & 11.2 & 7.1 & 3.6 & 5.4 & 5.1 & 5.5 & 6.2 & 5.6 & 3.5 & 4.6 & 3.9 & 5.2 & 9.2 & 5.1 \\
SF & 6.0 & 5.0 & 3.9 & 5.9 & 11.3 & 11.5 & 14.6 & 13.0 & 8.3 & 7.3 & 7.6 & 6.4 & 6.0 & 13.0 \\
FrP & 15.9 & 13.6 & 14.6 & 11.0 & 8.9 & 3.6 & 4.8 & 9.0 & 6.4 & 6.4 & 2.4 & 0.6 & - & - \\
CD & 7.8 & 2.2 & 6.4 & 3.2 & 8.3 & 4.6 & 4.8 & 4.7 & 5.1 & 2.8 & 4.3 & 1.8 & 1.0 & - \\
KrF/KD & 4.0 & 5.3 & 3.4 & 2.6 & 2.3 & 2.7 & 2.4 & 2.0 & 2.3 & 1.9 & 2.5 & 2.3 & 1.7 & 0.9 \\
DF & - & - & - & - & - & - & - & - & - & - & 7.4 & 12.0 & 13.3 & 13.9 \\
EL & - & - & - & - & - & - & - & - & 1.7 & 3.1 & 2.7 & 2.4 & 3.4 & 2.2 \\
\hline Turnout & 88.7 & 88.2 & 88.7 & 85.6 & 83.2 & 88.4 & 86.7 & 85.7 & 82.8 & 84.3 & 86.0 & 87.1 & 84.5 & 86.6 \\
\hline
\end{tabular}

Source: www.folketinget.dk.

Note: Party shares do not always add up to 100 per cent, as minor parties are omitted.

\subsection{The labour market reforms under social democratic governments, 1993-2001}

As indicated above, the SD began its transformation when the party was in opposition with the programme 'The New Century' (Det Nye Arhundrede) in 1992, and further working programmes and electoral manifes- 
tos that emphasised ALMP. After having failed to obtain a parliamentary majority with other parties via coalition or toleration agreements in the elections until 1990, due to its pronounced left-wing stance, the SD also changed its strategy in daily politics. The party began to present itself as a responsible party in terms of economic and fiscal policy. Still in opposition after the 1990 election, the SD cooperated with the ConservativeLiberal government on the 1992 and 1993 budgets to attract future support from the small centre parties (Green-Pedersen 2002a: 121ff). The strategy proved successful in 1993, when the centre-right government stepped down after a scandal and the SD was able to form a majority government with three small centre parties (RV, CD, KrF), headed by the new party leader Poul Nyrup Rasmussen (ibid; Green-Pedersen \& van Kersbergen 2002: 516).

Before I describe the social democratic government's labour market reforms after 1993, some explanatory remarks on the Danish unemployment benefit system are needed. The Danish unemployment benefit system is a voluntary insurance scheme administered by unemployment funds with close ties to the trade unions (Green-Pedersen 2002a: 70). The scheme is mainly financed through general taxation, but also through employer and member contributions. The nominal replacement rate is 90 per cent and hence very generous, but due to the existence of a maximum amount, only wage earners with lower incomes have an actual replacement rate corresponding to this. Actual replacement rates are also contingent on the indexation rule used for the calculation of benefits, where coupling to real wage development is the rule.

The SD's transformation became increasingly visible in terms of practical policies. The government implemented tax and labour market reforms in $1993 .{ }^{6}$ The labour market reform reflected the SD's new stance: it emphasised activation and employability principles, and eligibility criteria for unemployment benefits were tightened, as was the conditionality for benefit reception when participation in activation programmes became mandatory after two years of benefits. At the election in 1994 the SD lost both votes and its parliamentary majority, as one of its coalition partners, the Christian Democrats, failed to pass the 2 per cent threshold. Nevertheless, the SD survived and stayed in power, now as a minority government (together with the RV and CD).

Between 1995 and 1997, the activation principle was reinforced as the young and old unemployed, as well as previous recipients of social assistance, became subject to activation programmes. The latter also became subject to compulsory activation (e.g. Goul Andersen 2002; Green- 
Pedersen 2002b: 74ff; Merkel et al. 2008: 201; Goul Andersen \& Carstensen 2009: 77ff). This also implied a retrenchment of unemployment benefits for the persons concerned (cf. Green-Pedersen et al. 2001: 315). The elections in 1998 allowed the SD to continue in power with the Social Liberals. ${ }^{7}$

After the 1998 election, the SD launched a third round of labour market reforms. Once more, the eligibility period for unemployment benefits was curtailed, to four years now, making activation mandatory after one year on benefits. Further measures concerned activation of the unemployed above the age of 60 , earlier activation of unemployed young people, and a broader definition of suitable work. Breaking with former promises, the social democrats implemented a reform of the early retirement scheme (efterlønsreformen). This implied a moderate reduction of benefits and somewhat tighter eligibility criteria to increase incentives to remain in the labour market (Goul Andersen 2002: 71). ${ }^{8}$ Table 6.3 provides an overview of the labour market reforms implemented by social democratic-led governments between 1993 and 2001.

The summary of labour market reforms in Denmark under social democratic governments after 1993 clearly illustrates tightened eligibility criteria. The main focus was the activation of benefit recipients, as benefits became more and more conditional on participating in activation and employability programmes. Similarly, suitability criteria were sharpened and sanctions were introduced for people failing to take part in these measures. Another important element is the fact that older unemployed people also became subject to those principles. The unpopular reform of the early retirement scheme is one example of the strengthening of employability principles to increase incentives to remain in the labour market, including for older people. Thus, by strengthening conditionality and limiting eligibility for benefits, the SD's labour market policy between 1993 and 2001 showed clear signs of recommodification, contrary to traditional social democratic principles (cf. Goul Andersen 2002: 76). Access to benefits was no longer guaranteed through rights and universal schemes, but depended on settlements of claims and was accompanied by an individual obligation to re-enter the labour market as quickly as possible.

Expressing the effects of the labour market reforms in quantitative terms requires some qualifications, due to the nature of the reforms and data limitations. First, we have to rely on data reporting summary measures of replacement rates, that is, Scruggs (2006) and the OECD's summary measure (OECD 2010a). The latter includes a break in the time series, which does not allow comparison of replacement rates under the previous centre-right and the social democratic government. Nor is it possible to 
Table 6.3 Classification of labour market reforms introduced by SD-led governments, 1993-2001

\begin{tabular}{|c|c|c|c|}
\hline Year and legislation & Reform (status quo in brackets) & $\begin{array}{l}\text { Level of con- } \\
\text { ditionality }\end{array}$ & $\begin{array}{l}\text { Direc- } \\
\text { tion }\end{array}$ \\
\hline \multirow[t]{4}{*}{$\begin{array}{l}\text { 1993/4: Labour Market } \\
\text { Reform I }\end{array}$} & $\begin{array}{l}\text { Eligibility period for unemployment benefits } \\
\text { shortened to } 7 \text { years; mandatory activation } \\
\text { after } 4 \text { years on benefits (previously } 8 \text { years) }\end{array}$ & $\begin{array}{l}\text { Eligibility and } \\
\text { entitlement }\end{array}$ & $\mathrm{R}$ \\
\hline & $\begin{array}{l}\text { Tighter criteria to requalify for benefits } \\
\text { by taking part in activation or through } \\
\text { subsidised employment; } 6 \text { months of ordinary } \\
\text { employment required to qualify for benefits } \\
\text { (previously moderate criteria) }\end{array}$ & $\begin{array}{l}\text { Eligibility and } \\
\text { entitlement }\end{array}$ & $\mathrm{R}$ \\
\hline & $\begin{array}{l}\text { Introduction of compulsory individual action } \\
\text { plans for the long-term unemployed }\end{array}$ & $\begin{array}{l}\text { Behaviour/ } \\
\text { Conduct }\end{array}$ & $\mathrm{R}$ \\
\hline & Rights for unemployed aged 50-59 extended & Membership & $\mathrm{D}$ \\
\hline \multirow[t]{5}{*}{$\begin{array}{l}\text { 1995/6: Labour } \\
\text { Market Reform II }\end{array}$} & $\begin{array}{l}\text { Eligibility period for unemployment benefits } \\
\text { shortened to } 5 \text { years; mandatory activation } \\
\text { after } 2 \text { years on benefits ( } 7 \text { years after last } \\
\text { reform) }\end{array}$ & $\begin{array}{l}\text { Eligibility and } \\
\text { entitlement }\end{array}$ & $\mathrm{R}$ \\
\hline & $\begin{array}{l}52 \text { weeks of ordinary employment within } 3 \\
\text { years needed to qualify for unemployment } \\
\text { benefits (previously } 26 \text { weeks within } 3 \text { years) }\end{array}$ & $\begin{array}{l}\text { Eligibility and } \\
\text { entitlement }\end{array}$ & $\mathrm{R}$ \\
\hline & Compulsory activation after 2 years & $\begin{array}{l}\text { Behaviour/ } \\
\text { Conduct }\end{array}$ & $\mathrm{R}$ \\
\hline & $\begin{array}{l}\text { Tighter eligibility criteria for unemployed under } \\
25 ; \text { mandatory participation in education or job } \\
\text { training after } 26 \text { weeks on benefits implying } \\
\text { reduced benefits (less conditionality in previous } \\
\text { legislation) }\end{array}$ & $\begin{array}{l}\text { Behaviour/ } \\
\text { Conduct }\end{array}$ & $\mathrm{R}$ \\
\hline & $\begin{array}{l}\text { Tighter job suitability criteria for those } \\
\text { unemployed for longer than } 6 \text { months; } \\
\text { strengthening of sanctions if activation is } \\
\text { refused }\end{array}$ & $\begin{array}{l}\text { Behaviour/ } \\
\text { Conduct }\end{array}$ & $\mathrm{R}$ \\
\hline $\begin{array}{l}\text { 1997/8: Law on active } \\
\text { social policy to replace } \\
\text { bistandsloven }\end{array}$ & $\begin{array}{l}\text { Compulsory activation for people on social } \\
\text { assistance introduced (bistandsloven as social } \\
\text { assistance scheme without emphasis on } \\
\text { activation) }\end{array}$ & $\begin{array}{l}\text { Behaviour/ } \\
\text { Conduct }\end{array}$ & $\mathrm{R}$ \\
\hline \multirow[t]{2}{*}{$\begin{array}{l}\text { 1998/9: Labour } \\
\text { Market Reform III }\end{array}$} & $\begin{array}{l}\text { Eligibility period for unemployment benefits } \\
\text { shortened to } 4 \text { years; mandatory activation } \\
\text { after } 1 \text { year on benefits (previously } 2+3 \text { years) }\end{array}$ & $\begin{array}{l}\text { Eligibility and } \\
\text { entitlement }\end{array}$ & $\mathrm{R}$ \\
\hline & $\begin{array}{l}\text { Abolition of longer eligibility period for } 50-54 \\
\text { year-olds }\end{array}$ & $\begin{array}{l}\text { Eligibility and } \\
\text { entitlement }\end{array}$ & $\mathrm{R}$ \\
\hline
\end{tabular}


Table 6.3 Classification of labour market reforms introduced by SD-led governments, 1993-2001

\begin{tabular}{|c|c|c|c|}
\hline Year and legislation & Reform (status quo in brackets) & $\begin{array}{l}\text { Level of con- } \\
\text { ditionality }\end{array}$ & $\begin{array}{l}\text { Direc- } \\
\text { tion }\end{array}$ \\
\hline \multirow{5}{*}{$\begin{array}{l}\text { 1998/9: Early } \\
\text { retirement reform } \\
\text { (efterlønsreformen) as } \\
\text { part of Labour Market } \\
\text { Reform III }\end{array}$} & $\begin{array}{l}\text { Activation mandatory after one year of } \\
\text { unemployment; mandatory activation after } \\
6 \text { months for young unemployed; tighter } \\
\text { definition of suitable work after } 3 \text { months of } \\
\text { unemployment; registration at unemployment } \\
\text { office required from first day of unemployment }\end{array}$ & $\begin{array}{l}\text { Behaviour/ } \\
\text { Conduct }\end{array}$ & $\mathrm{R}$ \\
\hline & $\begin{array}{l}\text { Introduction of earmarked contribution to } \\
\text { obtain early retirement allowance }\end{array}$ & $\begin{array}{l}\text { Membership } \\
\text { Eligibility and } \\
\text { entitlement }\end{array}$ & $\mathrm{R}$ \\
\hline & $\begin{array}{l}\text { Contribution period to obtain early retirement } \\
\text { allowance increased to } 25 \text { years ( } 20 \text { years) }\end{array}$ & $\begin{array}{l}\text { Eligibility and } \\
\text { entitlement }\end{array}$ & $\mathrm{R}$ \\
\hline & $\begin{array}{l}\text { Introduction of incentives to remain in labour } \\
\text { market if claim to early retirement is rejected; } \\
\text { de facto increase of age for early retirement } \\
\text { from } 60 \text { to } 62 \text { years }\end{array}$ & $\begin{array}{l}\text { Eligibility and } \\
\text { entitlement } \\
\text { Behaviour/ } \\
\text { Conduct }\end{array}$ & $\mathrm{R}$ \\
\hline & $\begin{array}{l}\text { Standard rate of early retirement allowance } \\
\text { decreased to } 91 \text { per cent of maximum } \\
\text { unemployment benefits ( } 100 \text { per cent) }\end{array}$ & $\begin{array}{l}\text { Eligibility and } \\
\text { entitlement }\end{array}$ & $\mathrm{R}$ \\
\hline
\end{tabular}

Sources: Goul-Andersen (2002); Green-Pedersen (2002a, 2002b) Clasen \& Clegg (2007);

Dingeldey (2007); Plovsing (2007: chap. 4).

Notes: The classification of reforms in terms of level of conditionality and direction draws on Clasen \& Clegg's scheme (2007); R: recommodification, D: decommodification.

use OECD data on replacement rates for particular types of unemployment, as some reforms took place before the OECD began to gather the respective data and issue reports based on this data.

Second, some scholars have argued that the Danish reforms did not intend to reduce replacement rates per se, but aimed at activation and employability via tighter eligibility criteria and more intensive conditionality (e.g. Goul Andersen 2002). For instance, Klitgaard (2002: 188) characterised the Danish labour market reforms as creeping disentitlements, as the reforms did not directly retrench the benefits as such, but would have lasting effects through changed eligibility criteria and conditionality. In this respect, the social democrats did not reverse the effects of the previous centre-right government's decisions to temporarily freeze maximum benefit amounts and to modify the indexation rules for unemployment benefits. Likewise, Green-Pedersen (2002b: 7o) argues that formal replacement rates do not mirror the actual replacement rates in the case of Danish labour market reforms. This would imply only marginal 
decreases of replacement rates, but Lyle Scruggs' data (2006) nevertheless show some decline in replacement rates in Denmark over the period under consideration.

Table 6.4 Summary measures of benefit entitlements for Denmark, 1989-2002

\begin{tabular}{lcccccccc}
\hline & 1989 & 1991 & 1993 & 1995 & 1997 & 1999 & 2001 & $2002 / 03^{\mathrm{a}}$ \\
\hline $\begin{array}{l}\text { Replacement rate } \\
\text { (Scruggs) }\end{array}$ & 70 & 70 & 69 & 67 & 65 & 64 & 63 & 62 \\
\hline $\begin{array}{l}\text { Replacement rate } \\
\text { (OECD) }\end{array}$ & - & - & - & 65 & 62 & 61 & 51 & 50 \\
\hline
\end{tabular}

Source: Scruggs (2006); OECD (2010a).

Notes: The OECD summary measure is defined as the average of the gross unemployment benefit replacement rates for two earnings levels, three family situations and three durations of unemployment. Bold figures represent post-reform years.

a. for 2002 Scruggs (2006), for 2003 OECD (2010b).

In Table 6.4, Scruggs' data indicate that average replacement rates gradually declined under the social democratic government over the period when the three rounds of labour market reforms were launched. ${ }^{9}$ The same is true for the OECD measure, but the break in the time series between 1993 and 1995 calls for caution. This confirms that the social democrats in Denmark might not have targeted replacement rates as such, but that they were reduced over the years via the reforms. The reforms may also have effects that are only visible in economic downturns (cf. Klitgaard 2002: 188) or due to modifications of the indexation rules, which are not easily detectable using the sources above.

In sum, the labour market reforms implemented by the Danish social democratic government from 1993 to 2001 clearly indicated recommodification in terms of conditionality and employability. Even though it was unclear whether the reforms were actually responsible for lower replacement rates, the substance of the three rounds of labour market reforms clearly emphasised employability and tighter conditions for benefit entitlements, including mandatory activation. This made benefit recipients more dependent on participation in the labour market or activation schemes to take up work. By engaging in recommodifying reforms after 1993, the SD thus changed its traditional stance on the welfare state. We would expect this departure from traditional social democratic policy commitments, as formulated by Esping-Andersen and outlined in Chapter 2, to be accompanied by a dealignment of the party's core constituency. This will be exam- 
ined once we have outlined the context of party competition in Denmark in the reform period, to hypothesise the expected pattern of electoral change.

\subsection{Party competition and welfare state reforms, 1993-2001}

In the late 1980 os and early 1990 s, two major blocs and three centre parties played a decisive role in governmental formation in Denmark (e.g. Damgaard 2003). The left-wing bloc included the Social Democratic Party (SD), the Socialist People's Party (SF), and, after 1990, the small radical-left Red-Green Alliance (EL). ${ }^{10}$ The right-wing bloc was composed of the Liberal Party (Venstre), the Conservatives, (Det Konservative Folkeparti) and the far-right Progress Party (Fremskridtspartiet, FrP). The centre parties were the Social Liberals (Radikale Venstre, Rv), the Centre-Democrats (Centrumdemokraterne, CD) and the Christian Democrats (Kristeligt Folkeparti, KrF). As neither bloc had a majority after 1973, the three centre parties were decisive for the formation of coalition governments or for parliamentary support for minority governments, the latter being the rule in Denmark.

After more than a decade in opposition, the SD was able to form a majority government in 1993 during the electoral term 1990-94, as the three centre parties withdrew support for the Conservative-Liberal government as a consequence of a scandal and shifted sides to endorse the social democrats. This was also an effect of the SD's departure from its more pronounced left-wing stance in the $198 \mathrm{os}$, where the party tried to form a government with the SF. The attempt failed, as neither party won a parliamentary majority nor was able to get support from the centre parties. With its new leader, Poul Nyrup Rasmussen, and a new party constitution, the SD became more moderate and did not include the socialists in its coalition this time.

As mentioned above, the SD-led government implemented three labour market reform packages in the years between 1993 and 2001. Since the government's parliamentary majority position lasted only until 1994, the government had to use the two left-wing parties, the SF and the RedGreen Alliance, as support parties (Bille 1999; Nielsen 1999; Green-Pedersen 2002a: 124). In welfare and labour market reforms, the government also got parliamentary support from the bourgeois opposition parties (Green-Pedersen 2001: 976, 2002a: 125). In light of the theoretical propositions on the role of left competitors for the electoral prospects of Third Way social democrats, the SF deserves particular attention, as the party 
obviously represents the type of dangerous left-socialist competitor described in the theoretical chapter. Though the SF was an established leftwing contender for the Danish social democrats, the party obviously did not benefit from the reforms and even suffered a decline, as Tables 6.1 and 6.2 indicate. ${ }^{11}$

However, the SF's strategy under the social democratic minority government should have made it difficult for the party to capitalise on the welfare state reforms and pull social democratic core voters further to the left. This was due to the form of bloc competition in Denmark between left-wing and right-wing parties (e.g. Kitschelt 2001, GreenPedersen 2001, 2002a). ${ }^{12}$ The socialists were integrated in the left bloc and had been a supporting party throughout the SD-led governments after 1994. Moreover, by 2000 the 'SF was now involved in a large number of agreements with the SD-RV-government and had [...] attained the status of the most central supporter for the government' (Mortensen 2011: 303, own translation). Hence, the sF had limited room to attack the social democrats by engaging in a more pronounced opposition strategy. The latter implied the risk of toppling the government and creating a bourgeois majority if the centre parties were to shift sides again (cf. Bille 1999; Nielsen 1999: 68ff), and this was not in the SF's interest. This distinguishes the SF from the German Left Party, which had been in opposition to social democratic majority governments, allowing it to engage in pure vote-seeking strategies in times of welfare reform. Accordingly, the SF leadership was criticised for being too compliant in its cooperation with the social democratic government (cf. Spier \& Wirries 2007: 104; see also Mortensen 2011: chap. 17) $\cdot^{13}$ Neither did the party threaten the social democrats with a withdrawal of its parliamentary support as a consequence of the reforms. Thus although it was a dangerous challenger in principle, we would not expect the SF to have gained social democratic core votes between 1994 and 2001, since its strategy had seriously damaged its credibility.

By contrast, we would expect a right-wing authoritarian party, the Danish People's Party, to attract this voter segment thanks to the reforms. The party was founded in 1995 as a splinter of the declining Progress Party. The DF largely absorbed the FrP's votes in its first appearance in the 1998 Folketing election (Nielsen 1999). In contrast to the market-liberal Progress Party, the DF developed centrist views on socio-economic issues (Goul Andersen 2003b: 293, 2007: 37f). In line with Kitschelt's work (2003, 2004), the party can be characterised as social protectionist. We would expect this to allow the party to woo voters who are interested in 
maintaining core welfare programmes with a programmatic and populist agenda (Nielsen 1999; Rydgren 2004). The party also presented itself as a social corrective for the Liberal-Conservative government after 2001, for which the DF was the supporting party (Spier \& Wirries 2007: 101f). Thus, the DF was a competitor for the SD on the economic dimension, in line with the literature on social protectionist parties, which argues that this type of party is able to attract social democratic core constituents.

Moreover, like its 'mother party', the FrP, the DF represents authoritarian positions on socio-cultural matters, particularly on immigration. We would expect this to allow the party to make inroads among dissatisfied social democratic core constituents after the social democrats had abandoned their traditional welfare policy, since we would expect these voters to hold views closer to the DF on non-economic issues, especially immigration in the Danish case. Therefore, the DF should be the most dangerous competitor for the social democrats and their backing among their core constituency.

Another development in Danish party politics during this period needs to be addressed, namely the modernisation of the Liberal Party during the 1990 s. The party had traditionally advocated market-liberal principles and represented farmers' interests, but it began a modernisation process under Uffe Ellemann Jensen to attract new voter segments (Mortensen 2008: chap. 5). Vote shares increased, but the party did not win office in the 1998 election. Anders Fogh Rasmussen replaced Ellemann Jensen as leader after the election. He intensified the change process and his party abandoned its pronounced market-liberal views (Qvortrup 2002: 205, 210). Moreover, the party committed itself to the Danish welfare state, in contrast to its former programmatic stance (Mortensen 2008: 114ff). This went in line with an explicit appeal to social democratic voters, claiming that the SD no longer represented their interests (ibid: 111f).

The liberal Venstre party also changed the socio-cultural aspects of its agenda after Fogh Rasmussen became party leader. After 1998, the party adopted a tougher stance on immigration and law and order issues (Qvortrup 2002: 206f; Green-Pedersen \& Krogstrup 2008). One particular aim was to accommodate social democratic voters and limit possible losses to the DF (cf. Mortensen 2008: 141ff). Hence, the empirical analysis has to inspect whether Venstre's turn towards a catch-all electoral strategy and the fact that the party explicitly targeted social democratic voters on social policy, as well as on immigration, led to gains.

Having discussed the main features of party competition and the role of Danish competitor parties when the social democratic party reformed the 
welfare state, I now formulate the expected electoral consequences. First, I do not expect the Socialist People's Party to benefit from the recommodifying reforms of the SD government and to foster a realignment of social democratic core voters, given the party's lack of credibility. This makes the Danish case a special case, where credibility considerations affecting left-wing competitors to social democracy should limit the propensity to foster a left realignment.

Second, it is expected that the Danish People's Party would represent a more dangerous competitor for social democracy, as the party could foster a realignment of its core voters. This is because the DF could woo social democratic voters with its social protectionist appeal and its sceptical position on immigration, in line with attitudes of social democratic core constituents. The party is the type of right-wing party that constitutes a serious danger for Third Way social democrats. An additional aspect to be examined empirically is gains for the Liberal Party, Venstre, among the social democratic voter base, as the party moderated its ideological position on the economic dimension and adopted a stricter view on immigration and other domestic policy issues.

\subsection{Data and variables}

The data source for the analyses below is the Danish Election surveys for the 1994-2005 elections, which are used in both the descriptive and the statistical part of the analysis. The descriptive part first presents the attitudes of social democratic core voters towards potential or actual reforms that had been implemented. The respondents were asked about their attitudes towards tightened eligibility and suitability criteria as well as the generosity of benefits before the second and third package of labour market reforms, which actually implemented such measures. The first round was moderate, as explained above, since only the eligibility period for benefits was shortened from eight to (a still generous) seven years. ${ }^{14}$ These items capture the electorate's attitudes towards reform proposals before the social democrats actually implemented measures that came very close to the proposals of the 1994 election survey. Afterwards, I present the strength of the alignment of social democracy's core constituency during the period of investigation. Social democratic core voters are conceptualised as workers and lower white-collar employees that voted for the SD in the last election, as captured by the vote recall question in the data sets. 
The statistical part uses a multinomial logistic regression model with party choice as the dependent variable. The party choice variable consists of all relevant parties for the period of investigation, including abstention. For reasons of space, the analyses will report only the results for the theoretically important parties. The statistical analysis focuses on the 1998 and 2001 elections, which took place after the second and third round of labour market reforms. For the 1998 election, I used a proxy variable, asking whether a social democratic or a centre-right government is best at securing a balance between taxes and welfare, as a measure for attitudes towards reforms. The data set for the 2001 election contains an item that directly asks the respondents about their attitudes towards the Nyrup government's social policy, which is a fair measure of the attitudes towards this government's welfare state reforms. These items are used as an independent variable in the logistic regression models. I also controlled for the immigration issue as a second independent variable, since this is often seen as an explanation for the DF's rise after 1995. This was done by introducing a variable measuring whether immigration was seen as a threat to the Danish national character. The rationale is that immigration had been a salient issue in general and the most important socio-cultural issue in the period under consideration. Many authors have pointed to the immigration issue as the main explanation for the increasing support for the DF (Qvortrup 2002; cf. the volumes of Andersen et al. 1999; Goul Andersen \& Borre 2003; Goul Andersen et al. 2007).

\subsection{Results}

Attitudes towards reform proposals and party choice after 1993

As a first step, I present the attitudes towards potential reforms among three groups of voters in the 1994 election survey in Table 6.5. Except for the action plans that had been introduced in 1993 and reinforced and expanded to other unemployed groups later, all of these proposals mirrored the actual reforms to come in the second and third round of labour markets reforms quite well. The results demonstrate that it is the social democratic core constituency that disliked the reform proposals the most. For all four proposals, this voter group was always most sceptical regarding a proposed tightening of eligibility criteria and benefit cuts. Given that these proposals found their equivalents in the labour market reforms to be implemented later, we can - in line with the theoretical arguments expect the SD core voters to punish their party for these types of reforms. 
Table 6.5 Attitudes towards labour market reform proposals by voter group, percentage points

Tighter suitability criteria: force unemployed to take up work far from where they live [V164]

\begin{tabular}{lllcl} 
Voter group & Good proposal & Bad proposal & Don't know & Total \\
\hline Non-core constituency & 19.4 & 74.3 & 6.3 & 100 \\
Non-aligned core constituency & 12.3 & 77.2 & 10.4 & 100 \\
Aligned core constituency & 9.9 & 85.1 & 5.0 & 100 \\
$\mathrm{~N}=660$ & & & Chi 12.5 & $\mathrm{P}<.05$ \\
\hline
\end{tabular}

Set up individual plans of action for each unemployed person [V167]

\begin{tabular}{lllll} 
& Good proposal & Bad proposal & Don't know & Total \\
\hline Non-core constituency & 31.4 & 35.7 & 32.9 & 100 \\
Non-aligned core constituency & 27.6 & 30.3 & 42.2 & 100 \\
Aligned core constituency & 25.4 & 46.2 & 28.4 & 100 \\
$\mathrm{~N}=660$ & & & Chi 14.9 & $\mathrm{P}<.05$ \\
\hline
\end{tabular}

Limit young people's access to unemployment benefits [V168]

\begin{tabular}{lllll} 
& Good proposal & Bad proposal & Don't know & Total \\
\hline Non-core constituency & 28.2 & 57.6 & 14.2 & 100 \\
Non-aligned core constituency & 23.4 & 57.5 & 19.1 & 100 \\
Aligned core constituency & 14.7 & 71.8 & 13.6 & 100 \\
$\mathrm{~N}=660$ & & & Chi 13.7 & $\mathrm{P}<.05$ \\
\hline
\end{tabular}

Reduce benefits after one year of unemployment [V169]

\begin{tabular}{lllcl} 
& Good proposal & Bad proposal & Don't know & Total \\
\hline Non-core constituency & 32.4 & 56.1 & 11.6 & 100 \\
Non-aligned core constituency & 20.1 & 66.1 & 13.8 & 100 \\
Aligned core constituency & 15.9 & 79.3 & 4.8 & 100 \\
N=660 & & & Chi 26.5 & P<.01 \\
\hline
\end{tabular}

Source: Own calculations based on the respective items from Danish Election Study 1994.

Table 6.6 reports the vote shares among voters conceptualised as the social democratic core constituency and the remaining voters for the parties of theoretical relevance. The most striking feature is the SD's severe decline among its core constituents and among the non-core constituency after 1998. However, the major difference is a clear pattern of a realignment of parts of the social democratic core constituency with the Danish People's Party in this period. The DF more than doubled 
its share between 1998 and 2001, and retained its support among this voter group in the 2005 election. This does not apply to the non-core constituents, where the party only made moderate gains in 2005. The Liberal Party also won reasonable support among the social democratic voter base in 2001, bringing the party level with the social democrats. In contrast to the Danish People's Party, however, this support declined in 2005 .

Table 6.6 Party shares and non-voting among social democratic core constituency, Denmark 1998-2005 (per cent)

\begin{tabular}{lcccc}
\hline Core constituency & 1994 & 1998 & 2001 & 2005 \\
\hline SD & 36.5 & 42.5 & 28.9 & 29.6 \\
Venstre & 20.1 & 20.2 & 28.7 & 23.9 \\
SF & 8.7 & 8.2 & 4.8 & 3.7 \\
DF & $-(5.7$ for FrP $)$ & 7.4 & 15.8 & 17.0 \\
All other parties & 19.6 & 17.3 & 15.3 & 17.8 \\
Non-voters & 9.5 & 4.6 & 6.5 & 7.9 \\
\hline Non-core constituency & & & & \\
\hline SD & 13.3 & 31.4 & 23.6 & 18.4 \\
Venstre & 36.4 & 27.7 & 33.9 & 30.7 \\
SF & 8.9 & 6.2 & 7.3 & 7.2 \\
DF & $-(4.1$ for FrP) & 6.5 & 6.9 & 8.9 \\
All other parties & 34.3 & 25.0 & 26.1 & 31.1 \\
Non-voters & 3.2 & 3.2 & 2.3 & 3.3 \\
\hline Source:Danish Election & & & &
\end{tabular}

Source: Danish Election Studies 1994-2005.

Note: The percentage points indicate what percentage of a voter group chose a particular party or abstained in the respective elections from 1994-2005. Figures do not always add up to 100 per cent due to rounding.

The two left-wing parties, the SF and the Red-Green Alliance (latter not shown), did not benefit from the social democratic decline and by and large retained their support among both groups or even declined, as the figures for the SF indicate. In line with expectations, no left competitor was able to attract social democratic core voters after 1994 or 1998, even though the social democrats engaged in reforms that went against the core constituency's interests. There were some gains for the group of other parties among the non-core voters in 2005 , half of which can be attributed to gains for the Social Liberals. 
Non-voting slightly increased among the social democratic core electorate after 1998 , but not in a way that shows a significant dealignment towards the non-voter camp. However, I do not focus on non-voting explicitly in the remainder of the analysis, since all analyses below do not yield any significant effect as regards to increased non-voting among social democratic core voters due to the reforms. This differentiates the Danish case from the British case in particular, but also the German case analysed above, and will be further addressed in Chapter 8. Moreover, turnout rates in Denmark remained in a rather narrow interval between 84.3 and 87.1 per cent in the period examined in this chapter, yielding no trend at all (cf. Table 6.2).

\section{Alignment of SD's core constituency, 1994-98}

As outlined above, the social democrats continued to reform the Danish welfare state in the electoral period 1994-98, especially the labour market. This period was also characterised by the emergence of the Danish People's Party, which was somewhat marginalised in Danish politics in its early years. Left-wing parties were the parliamentary basis of the SD-RV government in this period, and we would thus also expect them to have limited mobilising power among social democratic core voters due to their stance on socio-cultural matters. To measure the attitudes towards reforms in this period, I used the respondents' assessment of whether the incumbent social democratic government was best at securing a fair balance between tax burden and social security. The rationale behind this analysis was to assess whether the social democrats had already lost a significant share of their core voters in the 1998 election and to determine whether welfare policy played a large role in core constituents' choice of party, even though the item on welfare policy is only a proxy, as discussed above. The results are expressed as predicted probabilities in Table $6.7 \cdot{ }^{15}$

The figures show that the social democrats were able to mobilise almost 90 per cent of their aligned core constituency in the 1998 election, so long as they were seen as the party to secure the right balance between taxes and social security (left-hand side of panel). As long as core voters attributed this image to the social democrats, no other party was able to pull a considerable share of core constituents away from them. With 5.1 per cent, the SF was the only party in this group to achieve more than 5 per cent. 
Table 6.7 Predicted probabilities of vote choice for attitudes towards welfare policy among aligned core constituents, 1998 (per cent)

\begin{tabular}{lcc}
\hline & $\begin{array}{c}\text { Balance tax welfare best secured by } \\
\text { SD: yes }\end{array}$ & $\begin{array}{c}\text { Balance tax welfare best secured by } \\
\text { SD: } \text { no }\end{array}$ \\
\hline SD & 88.6 & $66.0^{*}$ \\
Venstre & 0.2 & $5.0^{*}$ \\
SF & 5.1 & 3.9 \\
DF & 0.4 & $6.8^{*}$ \\
Non-voting & 2.1 & 3.7 \\
\hline
\end{tabular}

Source: Predicted probabilities obtained from multinomial logistic regression model in Table A4.2 using Clarify. Note: The number of simulations to obtain the probabilities was set to 1,000 . Figures do not always add up to 100 per cent as not all parties are listed in table. ${ }^{*} p<.05$. for difference between the columns.

Turning to the group of core constituents who do not think that a social democratic government is securing a fair balance between the tax burden and social security (right-hand side of panel), support for the social democrats has declined, but the party still attracts two out of three aligned core constituents. Here, the Danish People's Party made some modest but significant gains. Not surprisingly, these gains concern voters who are sceptical about a social democratic government and concerned about immigration, but the figure does not exceed 10 per cent (not shown). The Liberal Party now mobilises 5 per cent of former SD core voters, which is a significantly different result compared to the party's performance in the other group (0.2 per cent). The SF gains almost the same share of former social democratic voters if they do not see SD as securing a fair balance between taxes and social security. This is not surprising, as the SF supported a social democratic minority government in this period. Other parties also benefit if voters are disillusioned with the SD's ability to secure a fair balance between taxes and social security; the Conservatives are the biggest winner, with 4.6 per cent (not shown).

The results for 1994-98 suggest that the social democrats retained large shares of their core constituents despite these constituents' doubts that the party could secure a fair balance between taxes and welfare. There was no clear sign of a realignment of core voters due to dissatisfaction with the party's welfare policy, as reflected in the stable electoral support for the SD between 1994 and 1998 shown in Tables 6.1 and 6.2. However, the analysis also revealed the first gains for the DF and the Liberals among voters with negative views of the social democratic welfare policy. 
Alignment of SD's core constituency and breakthrough of the Danish

People's Party, 1998-2001

As discussed above, the period between 1998 and 2001 comprised another round of welfare state reforms by the social democratic government. In contrast to 1994 and 1998, we would now expect this to account for the declining support for the social democrats and the rise of the Danish People's Party, as the descriptive analyses above suggest. As mentioned, the Danish election study for 2001 includes a variable asking respondents to assess the welfare policy of the incumbent social democratic government. This was used to construct a term indicating whether the voters had a negative or non-negative opinion of the Nyrup Rasmussen government's welfare policy in the 1998-2001 term. The item used for the immigration issue is a dummy indicating whether immigration is seen as a threat to the Danish national character. The voter groups are identified in the same way as in the previous section. Party choice is the dependent variable. The results for the relevant parties are shown in Table 6.8. I ran two models; the first one only examined attitudes towards the government's welfare policy and the second controlled for immigration, as this is by far the most prominent rival explanation for electoral change in this period.

In the upper half of the table, the figures demonstrate first that the social democrats would lose substantially if core voters were disaffected with the welfare policy of the incumbent social democratic government. The left-hand side of the panel shows that those who were satisfied stuck to the social democrats with a probability of at least two-thirds, while a negative attitude towards immigration only causes moderate losses, as seen in the second column in the lower half of the table. Support for the SD dropped heavily to 21 per cent among core voters who were displeased with the party's social policy. In line with expectations, the Danish People's Party drew significant support from former social democratic core voters who opposed the SD's welfare policy. By contrast, the socialists were not able to benefit among this segment of voters. Another striking effect is the strong gains for the Liberals. Almost one out of three disaffected social democratic core voters shifted to the Liberals in this election. The results provide strong evidence for the suspected electoral effects of the reforms ${ }^{16}$ As mentioned, immigration was the most common explanation for electoral change in the period under review.

The lower half of Table 6.8 shows that controlling for immigration does not change the quintessence of these findings. The SD's losses were due more to attitudes towards its welfare policy than to whether voters 
Table 6.8 Predicted probabilities of vote choice for attitudes towards immigration and welfare policy among aligned core constituents (per cent)

\begin{tabular}{|c|c|c|c|c|}
\hline Party Choice & \multicolumn{2}{|c|}{$\begin{array}{l}\text { Assessment of welfare policy: } \\
\text { good/neither good nor bad }\end{array}$} & \multicolumn{2}{|c|}{$\begin{array}{c}\text { Assessment of welfare } \\
\text { policy: bad }\end{array}$} \\
\hline SD & \multicolumn{2}{|c|}{72.7} & \multicolumn{2}{|c|}{$20.9^{*}$} \\
\hline Venstre & \multicolumn{2}{|c|}{8.5} & \multicolumn{2}{|c|}{$31.5^{*}$} \\
\hline SF & \multicolumn{2}{|c|}{4.4} & \multicolumn{2}{|c|}{3.2} \\
\hline DF & \multicolumn{2}{|c|}{4.4} & \multicolumn{2}{|c|}{$23.0^{*}$} \\
\hline All other parties & \multicolumn{2}{|c|}{6.5} & \multicolumn{2}{|c|}{14.4} \\
\hline Non-voting & \multicolumn{2}{|c|}{3.5} & \multicolumn{2}{|c|}{7.0} \\
\hline & \multicolumn{2}{|c|}{$\begin{array}{l}\text { Assessment of welfare policy: } \\
\text { good/neither good nor bad }\end{array}$} & \multicolumn{2}{|c|}{$\begin{array}{l}\text { Assessment of welfare } \\
\text { policy: bad }\end{array}$} \\
\hline $\begin{array}{l}\text { Party choice if controlled } \\
\text { for immigration }\end{array}$ & $\begin{array}{c}\text { Immigration as } \\
\text { threat: no }\end{array}$ & $\begin{array}{c}\text { Immigration as } \\
\text { threat: yes }\end{array}$ & $\begin{array}{c}\text { Immigration as } \\
\text { threat: no }\end{array}$ & $\begin{array}{c}\text { Immigration as } \\
\text { threat: yes }\end{array}$ \\
\hline SD & 75.0 & 68.5 & $27.3^{*}$ & $16.3^{*}$ \\
\hline Venstre & 6.7 & 11.1 & $30.4^{*}$ & $32.8^{*}$ \\
\hline SF & 6.0 & 2.2 & 5.8 & 1.3 \\
\hline DF & 1.3 & $8.6+$ & $7.5^{*}$ & $32.8^{*}$ \\
\hline All other parties & 7.6 & 5.6 & 20.8 & 10.5 \\
\hline Non-voting & 3.5 & 3.9 & 8.2 & 6.3 \\
\hline
\end{tabular}

Source: Predicted probabilities obtained from multinomial logistic regression model in using Clarify.

Note: The number of simulations to obtain the probabilities was set to 1,000. Figures do not always sum up 100 per cent due to rounding. ${ }^{*} p<.05$ for difference to column on the very left; + indicates differences in the left-hand side panel.

regard immigration as a threat. There was no difference for the SF concerning welfare, whereas the party seems to have been disliked by core voters concerned about immigration. This may indicate that the party's libertarian stance also mattered. The Danish People's Party could only mobilise strongly on the immigration issue if social democratic core voters were alienated by the SD-led government's welfare policy. The respective category for the DF can be clearly distinguished from the other three constellations, suggesting that immigration only became such a large vote-puller for the DF in the 2001 election due to the dissatisfaction with labour market reforms under the social democratic government.

The Liberal Party's gains were still related to the social policy dimension and to immigration as such. The results suggest that Venstre gained more votes among former social democratic core voters who were dis- 
pleased with the SD's welfare policy irrespective of their attitude towards immigration.

In sum, support for the social democrats was significantly contingent on the assessment of the welfare reforms under Nyrup Rasmussen. The party lost heavily among former core voters who opposed the welfare policy. In line with expectations, these voters realigned with the Danish People's Party in the 2001 election. This could not be merely explained by immigration, but has its origin in the social democratic government's welfare policy. As suspected, the Socialist People's Party did not attract former social democratic core voters, since the party had dirty hands. Another striking development was the shift of the SD's core supporters to the party's main rival in the government formation, Venstre. The Liberals unexpectedly attracted one-third of these voters; this is an anomalous finding and will be discussed in the conclusion.

A similar analysis using the 2005 election data (not shown) demonstrates that the effects were lasting. The realignment with the DF proved stable, as the party retained nine out of ten voters from the social democratic voter base. The social democrats did not recapture considerable shares of voters. The Liberals lost some votes from this segment, but continued to perform quite well among them. Keeping in mind the results from Table 6.6, we have confirmed with the additional analysis that the patterns of electoral change in the 2001 election lasted in the 2005 election.

\subsection{Conclusion}

The chapter examined what happens when social democrats reform the welfare state and face competitors from both sides of the political spectrum, as well as a mainstream party, that react to the social democrats' strategic move. The chapter looked at the electoral consequences for the Danish social democrats after the party engaged in Third Way welfare state reforms after 1993. In line with my theoretical elaborations, the SD's traditional voter alignment was based on its advocacy and implementation of a universalistic and decommodifying welfare state in Denmark. I hypothesised that the party would lose electoral ground after engaging in recommodifying labour market reforms. I expected that, unlike in other countries, it would not be a contender from the left that would be able to foster a realignment of social democratic core voters, but rather a right-wing party, the Danish People's Party. This party was expected to absorb the dissatisfied social democratic core constituents, as the re- 
forms worked as a catalyst for the electoral effects of the immigration issue, on which the DF was close to the attitudes of social democratic core voters. Moreover, we also had to look at possible gains for the liberal party Venstre, as the party turned into a catch-all party during the period under review and accommodated the attitudes of traditional social democratic core voters.

The results confirmed the expected realignment of social democratic core constituents with the Danish People's Party due the disaffection with the welfare state reforms and the expected relevance of the immigration issue for the DF's gains. The analysis demonstrated that opposition to the social democratic government's welfare policy induced this realignment and that the shift to the DF was lasting, as the party kept and even increased its general electoral share and its support among the social democratic core constituency after 1998.

In contrast to the German case, a left-socialist challenger was not able to attract dissatisfied social democratic core voters as a consequence of the reforms. The left-wing SF is a welfare party, but supported the reformminded social democratic government in parliament after 1994. I argued that this made the SF unelectable for social democratic core voters, as it left the SF lacking credibility in their eyes. Accordingly, the left socialist competitor failed to achieve a realignment.

Another striking development was the electoral gains of the Liberal Party after it moderated its stance on welfare in the late 1990 os. The party made inroads among the social democratic rank and file, and the analysis shows that negative attitudes towards the social democrats' welfare policy explain these changes to a considerable degree. Although Venstre did not retain its strong position among these voter groups after gaining office in 2001, it is likely that a realignment occurred. In contrast to its electoral record before the 1990s, Venstre now has much stronger backing among working class constituencies, and has been electorally stronger than the social democrats for about a decade. This is a new development in Danish politics, and one that coincided with the welfare state reforms of social democratic governments between 1993 and 2001. ${ }^{17}$ Unlike the DF, Venstre did not maintain its support among the social democratic core electorate, but the rising support for the party is nevertheless an anomaly and somewhat puzzling, on the grounds that despite its more welfarist stance, it was also parliamentarily involved in the labour market reforms of the Nyrup government. Future research should be undertaken to shed more light on the development of Venstre's electoral alliances after 1993 and the actual mechanisms underlying the process described in this chapter. ${ }^{18}$ 
Non-voting did not substantially increase, and the analyses did not reveal that attitudes to social policy had significant effects on abstention. This marks a sharp contrast to both the British and German cases, which will be briefly discussed here. Denmark has traditionally had a remarkable turnout, in an interval between 85 and 9o per cent (Elklit et al. 2005). This was also true for the period examined in this book, and there were no signs that the reform-averse social democratic core constituents would follow their British and German counterparts into the non-voter camp, as seen in the two previous chapters. One general reason is that Denmark has a rather low electoral threshold, making the political system more responsive to new electoral demands and providing dissatisfied voters with a lot of alternatives to choose from. This has kept political trust at a higher level (Marien 2011) and has ensured that people from lower social strata continue to vote (Elklit et al. 2005).

One particular reason in this respect is that the low threshold does not marginalise new or small parties that appeal to voters who are dissatisfied with political decisions or the electoral programmes of the established parties. That has allowed many new parties to soak up the protest vote and to obtain parliamentary representation (examples include the Centre Democrats and Progress Party during the 1970s, the Unity List since the late 1980s, the Danish People's Party since 1995 or the Liberal Alliance in recent years). With respect to the research question, the Danish People's Party was not institutionally marginalised beforehand and could appeal to social democratic core voters after 1995 without risking extinction in case of bad results or political marginalisation. This is also one explanation in the study by Elklit et al. (2005) on turnout in Denmark, in which the Danish People's Party on the right and the parties on the far left are seen as a mobilising factor that does not necessarily exist in countries with higher electoral thresholds. Another more explicit reason, in view of the welfare state reforms examined in this study, is the fact that two parties (Venstre and DF) actively wooed the social democratic core constituency and aligned their (new) electoral programmes to this voter segment. In sum, disaffected social democratic core voters had two clear alternatives in Denmark, compared to their British and German equivalents, who faced no or only one alternative to abstention.

Moreover, the results have shown that immigration, as a prominent rival explanation for the Danish case, cannot be the main explanation for the electoral change found in the analysis. By contrast, attitudes towards the social policy of the social democratic government were the driving force of the realignment of social democratic core constituents 
with the Danish People' Party and, surprisingly, the Liberal Party. One might object that the Socialist People's Party could not mobilise new voters from this segment because its libertarian stance on domestic issues had an alienating effect. This may be true, as analyses controlling for immigration has shown, but it does not explain why the party, despite its welfare image, did not win on welfare policy during the period under review. Immigration can, of course, be a supplemental explanation for the electoral change in Denmark, but the welfare reforms triggered realignments to the DF and Venstre. The DF could only appeal so strongly on the immigration issue once the welfare link between the SD and its core constituency had been broken. The 2001 election was not only an election on immigration, but also, surely, a welfare election, as maintained by Goul Andersen (2003b). Likewise, Giger (2011: 129) has shown that social policy was the major issue in the 2001 election, and not immigration. I will further address this rival explanation in the comparative summary in Chapter 8.

This chapter may thus contribute to the literature on right-wing parties and their electoral support. The DF's breakthrough is evidence that under certain circumstances, a right-wing party can foster a realignment of social democratic core voters as a consequence of welfare state reforms by using its respective electoral appeal and given the inability of left-wing competitors to attract those votes. In this case, a right-wing party can be a more dangerous contender for Third Way social democrats than a leftwing party.

This suggests that the lack of a left realignment and the rise of the right-wing DF in Denmark are a consequence of the interaction between dissatisfaction with welfare state reforms and the positioning of parties on socio-cultural issues. The Danish case was special in that left-wing parties could not benefit from disaffection with unpopular welfare reforms implemented by a social democratic government. The next chapter will examine the electoral fortunes of the Swedish SAP, a party that - in contrast with the British, German and Danish social democratic parties analysed above - did not engage in an outright transformation. 


\section{Sweden}

The Swedish social democratic party (Sveriges Socialdemokratiska Arbetareparti, SAP) is often seen as a prototypical social democratic party. Due to its electoral strength, the SAP was the dominant Swedish party in the 2oth century, with long and often uninterrupted incumbencies allowing the party to realise its ambitious social policy objectives (e.g. Svensson 1994; Arter 1999a; 2003; Immergut 2002). Similarly, the Swedish welfare state is regarded as the closest match to Esping-Andersen's ideal type of social democratic welfare state model (1990), with its generous universal social security schemes leading to an extraordinary degree of decommodification (Korpi \& Palme 1998).

This chapter looks at the electoral prospects of a social democratic party that has not transformed itself under a Third Way agenda, but has implemented more moderate reforms. During the economic crisis in the 1990 , the SAP cut welfare benefits and introduced welfare reforms, but was able to retain its traditional attachment to social democratic values (Anderson \& Meyer 2004: 156; Bonoli 2004: 208). When the crisis was over, it withdrew some of the reforms. Other reforms were not part of a path-breaking policy change under a Third Way label, but largely in line with the social policy legacy of Swedish social democracy, as ALMPS and workfare elements have always existed (Hort 2001). Under these conditions, I would expect social democrats to retain a large proportion of their core constituents and not experience a dealignment or realignment of these voters. The chapter controls for one important rival explanation, the suspected decline of class voting. If the chapter reveals a higher degree and no or only a moderate decline in class voting - understood as backing for the social democrats among the core constituency - the reforms in the three other cases must be regarded as a crucial factor for the changing alignment of core social democratic voters. 


\subsection{The Swedish social democratic party and its social policy}

The Swedish social democrats introduced three party constitutions in the second half of the 2oth century and one immediately after the turn of the millennium (SAP 1960, 1975, 1990, 2001). The SAP's party constitutions emphasise egalitarianism and solidarity as the party's basic principles. Various passages in the constitutions criticise the effect of pure market allocation, and the welfare state and social policy are seen as the means to alleviate these effects. Each programme emphasises income maintenance in case of sickness, old age, invalidity and unemployment via universal social security schemes. Redistribution through taxation and a wage policy based on solidarity are also emphasised, to improve the living standards of the lower social stratum. However, what makes the SAP different from the other social democratic parties examined above is the reference to ALMP, both in the 1960 and 1975 programmes and in the later ones. ALMPS are seen as an instrument to fight unemployment by upgrading and supporting the labour force to adapt to changing working conditions.

The social policy record of the Swedish social democrats shows that the SAP realised its social policy aspirations by developing a highly decommodifying welfare state in the second half of the 2oth century, given its politically dominant position. It also indicates the particular nature of Swedish social democracy, namely its early reliance on workfare principles.

After the Second World War, the SAP held office for more than 30 years without interruption (1945-76). ${ }^{1}$ As a major social policy invention in 1948 , which was copied by other Nordic countries, the party implemented a universal flat-rate pension scheme and abolished the hitherto existing eligibility criteria for old-age pensions (Esping-Andersen \& Korpi 1987: 49). In the 1950s, the SAP (in coalition with the Agrarian Party) introduced compulsory and publicly-run health and accident insurance schemes to replace private insurance funds, with opposition from other centre-right opposition parties (Esping-Andersen \& Korpi 1987: 49). After intense political debate and the end of the SAP-Agrarian coalition, the SAP accomplished employer-financed earnings-related pensions (Allmän Tillägspension, АTP), which came into effect in 1963, as well as supplemental earnings-related schemes for other welfare schemes (Esping-Andersen 1985: 108f; Esping-Andersen \& Korpi 1987: 53; Olsson 1990: 119).

The post-war 1940s saw the formulation of the active manpower policy and the establishment of the National Labour Market Board (Arbets- 
marknadsstyrelsen, AMs), also against the wishes of the bourgeois opposition parties (Esping-Andersen \& Korpi 1987: 58; Olsson 1990: 132). The main focus of the AMs had been to secure every citizen's right to become a wage earner and to organise the ALMP, including evaluation of the unemployed's willingness to take up work or participate in ALMP measures. In order to qualify for income maintenance via generous social benefits, the unemployed had to show willingness to search for and take up work or to participate in qualification programmes. The role of the state was to support the unemployed with ALMP and qualification measures so that they could rejoin the labour force. The foundation of the AMs thus established the work-to-welfare idea as an important element of the RehnMeidner plan and as one of the SAP's early principles (Hort 2001: 249). In this vein, a certain degree of conditionality was implemented early on in the Swedish welfare state. The system has been characterised as a civilised version of workfare (Hort 2001) and has been internalised by the Swedish workforce. This marks a crucial difference to the other social democratic parties examined above and also for the path of labour market policies in the 1990 os, as we will see in Section 7.3.

After the constitutive pillars of the Swedish welfare state had been implemented under social democratic governments, the existing policies were reinforced in the 1960 s and 1970s. In response to a recession, the active manpower policy administrated by the AMs was extended by new employment programmes, in order to upgrade the labour force and increase the labour supply (Esping-Andersen \& Korpi 1987: 61; Olsson 1990: 133). The eligibility period of the unemployment benefits was extended, and special allowances for elderly members of unemployment insurance funds were introduced (ibid: 151, 157). In 1974, the replacement rates of unemployment insurance increased substantially from what was originally 50-6o per cent, although the initial benchmark of 90 per cent was not reached in practice (Olsson 1990: 156). Moreover, the replacement rate for the health insurance scheme from 70 to 90 per cent in the period between 1963 and 1974, and waiting days were abolished in 1967 (ibid: 13off, 152).

In 1974, the union-administered and still voluntary unemployment insurance scheme was supplemented by public unemployment assistance to cover the uninsured or those who were ineligible for benefits in the union scheme (Olsson 1990: 134; Åmark 2005: 111). After 30 years in office, the SAP lost power in 1976, when a centre-right government led by the Centre Party took over. The bourgeois parties held office until 1982, with some interruptions in government composition (see Särlvik 2002: 257). ${ }^{2}$ In this 
period, neither major social policy innovations nor significant rollbacks took place, given the electoral threat of the SAP (Huber \& Stephens 2001: 241; Immergut \& Jochem 2006: 119-120). The first, modest austerity measures were not introduced until 1980 (Olsson 1990: 223f; Huber \& Stephens 2001: 241). ${ }^{3}$ The most controversial topic - fiercely opposed by the social democrats - was the reintroduction of waiting days for sick pay and a reduction of the replacement rate for health insurance from 90 to 87 per cent. As the latter measures were seen as affecting social democratic core voters in particular, the SAP 1982 electoral campaign focused on these issues, and the party promised to withdraw the cuts and to increase unemployment benefits (ibid; Starke 2008: 169).

The SAP returned to power with the 1982 election and, as promised, abolished the waiting days for sick pay and raised unemployment benefits. The 1980 os marked a watershed for the SAP in other policy areas than social policy, as the party introduced new policy paradigms under its new 'Third Road' agenda (Feldt 1985; cf. Pontusson 1992a, 1992b for a critical assessment). The paradigm shift was limited to economic policy and did not affect social policy, unlike other paradigm shifts under Third Way labels (Huo 2009: 70). The SAP even engaged in a further expansion of the welfare state (cf. Palme \& Wennemo 1998; Starke 2008: 169). After the SAP won the 1988 election, Sweden was hit by an economic crisis. The party's response to the crisis will be discussed in Section 7.3.

Summing up the ideological commitment to the welfare state in its party constitutions and the policy record of Swedish social democracy, it becomes clear that the party successfully realised a highly decommodifying welfare state in line with its ideology. In contrast to most of its sister parties, the SAP always promoted ALMP as one aspect of its productivity-centred ideology. These principles were incorporated in the SAP's social policy agenda at an early stage and realised in Swedish welfare policies. Moreover, they were persistently advocated by the party, administered through the union-run unemployment funds and internalised by the working class as the SAP's core constituency. This constitutes a major difference from other social democratic parties - with the exception of the Norwegian DNA - where such principles and policies had been part of the transformation towards a Third Way agenda, and thus marked a break with the social policy legacy of unconditional rights to income-maintaining social security benefits (Stjernø 2005: chap. 4; Huo 2009). 


\subsection{The core constituency of Swedish social democracy}

In terms of the framework on the alignment of core voters to social democratic parties in Chapter 2, the Swedish social democratic party should have been able to align particular classes due to its successful realisation of decommodification. Table 7.1 demonstrates that the SAP indeed drew on the support of those classes conceptualised as the social democratic core constituency in Chapter 2 before the crisis of the 1990s. Manual workers and lower white-collar employees were the party's electoral backbone during the golden age of the welfare state, as well as after the two oil crises in 1973 and 1981. In contrast to its British or Danish sister parties, the SAP gained much more support among the lower white-collar class as a result of its strategic courting of this class (Svensson 1990, 1994; Åmark 2005). In terms of social policy, this has been attributed in particular to the introduction of the earnings-related pension scheme (АTP) in 1959, as the social democrats created a broader wage-earner alliance (Svensson 1990, 1994; Esping-Andersen 1985: 108ff; Arter 1999a: 152, 2003: 97; Åmark 2005: 118ff). ${ }^{4}$ The SAP had a large core constituency during the second half of the 2oth century. Despite signs of a decline that began in the 1970s, the SAP always remained dominant among those segments.

Table 7.1 Party shares for selected parties by selected social classes, Sweden 1960-94

\begin{tabular}{|c|c|c|c|c|c|c|c|c|c|c|}
\hline & & 1960 & 1968 & 1976 & 1979 & 1982 & 1985 & 1988 & 1991 & 1994 \\
\hline \multirow[t]{3}{*}{ SAP } & RNM & 55 & 54 & 43 & 42 & 43 & 43 & 44 & 36 & 50 \\
\hline & Industrial & 83 & 79 & 68 & 71 & 75 & 71 & 73 & 61 & 73 \\
\hline & Other workers & 71 & 69 & 58 & 62 & 62 & 56 & 60 & 49 & 57 \\
\hline \multirow[t]{3}{*}{ M } & RNM & 10 & 9 & 13 & 24 & 29 & 20 & 17 & 23 & 22 \\
\hline & Industrial & 2 & 2 & 3 & 5 & 7 & 10 & 6 & 10 & 6 \\
\hline & Other workers & 4 & 5 & 5 & 8 & 13 & 13 & 7 & 14 & 11 \\
\hline \multirow[t]{3}{*}{ VPK } & RNM & 1 & 2 & 3 & 3 & 5 & 6 & 7 & 2 & 3 \\
\hline & Industrial & 4 & 2 & 5 & 5 & 5 & 5 & 4 & 3 & 7 \\
\hline & Other workers & 3 & 1 & 5 & 5 & 4 & 5 & 6 & 4 & 4 \\
\hline \multirow[t]{3}{*}{ C } & RNM & 6 & 10 & 24 & 12 & 12 & 7 & 9 & 10 & 6 \\
\hline & Industrial & 4 & 9 & 17 & 12 & 10 & 6 & 7 & 6 & 6 \\
\hline & Other workers & 11 & 14 & 22 & 15 & 13 & 11 & 12 & 11 & 9 \\
\hline
\end{tabular}

Source: For 1960 and 1968: Oskarsson (1994); for 1976-2002: Oscarsson \& Holmberg (2008). Notes: RNM: Routine non-manual; Swedish studies normally distinguish between industrial and other workers. 
The traditional centre-right parties' performance among the social democratic voter base does not reveal a consistent pattern. With the exception of the Centre Party in the 1970s, neither party made considerable and lasting inroads among those voters (Liberals not shown). The stable support among workers and lower white-collar employees (cf. Arter 2002: 14) for the Communist Party VPK - later the Left Party - was attributed to the so-called comrade vote; that is, social democratic sympathisers 'lend' their vote to the communists to increase the SAP's parliamentary power resources and bargaining potential (Arter 2003: 77).

Table 7.2 shows the vote shares for Swedish general elections after constitutional reforms in 1969, when the country shifted to unicameralism with the Riksdag as a one-chamber parliament (e.g. Särlvik 2002). Särlvik (2002) has identified this period as Sweden's sixth electoral era, due to the changes in the electoral system, and it is used as the period of reference here. The figures demonstrate the SAP's electoral dominance. It remained the strongest party in the years after 1970, with a double-digit distance to the next party (with the exception of the 2006 election). The continued electoral dominance of Swedish social democracy has been described by Arter (2003: 83). The SAP averaged 46.9 per cent of the votes under the old two-chamber system from 1944-69.

Table 7.2 Vote shares in Swedish general elections, 1970-2006

\begin{tabular}{lrrrrrrrrrrrr}
\hline & 1970 & 1973 & 1976 & 1979 & 1982 & 1985 & 1988 & 1991 & 1994 & 1998 & 2002 & 2006 \\
\hline SAP & 45.3 & 43.6 & 42.7 & 43.2 & 45.6 & 44.7 & 43.2 & 37.7 & 45.3 & 36.4 & 39.9 & 35.0 \\
M & 11.5 & 14.3 & 15.6 & 20.3 & 23.6 & 21.3 & 18.3 & 21.9 & 22.4 & 22.9 & 15.3 & 26.2 \\
C & 19.9 & 25.1 & 24.1 & 18.1 & 15.5 & $12.4^{1}$ & 11.3 & 8.5 & 7.7 & 5.1 & 6.2 & 7.9 \\
FP & 16.2 & 9.4 & 11.1 & 10.6 & 5.9 & 14.2 & 12.2 & 9.1 & 7.2 & 4.7 & 13.4 & 7.5 \\
VPK $^{2}$ & 4.8 & 5.3 & 4.8 & 5.6 & 5.6 & 5.4 & 5.8 & 4.5 & 6.2 & 12.0 & 8.4 & 5.9 \\
KD $^{3}$ & 1.8 & 1.8 & 1.4 & 1.4 & 1.9 & $\ldots$ & 2.9 & 7.1 & 4.1 & 11.7 & 9.1 & 6.6 \\
MP & - & - & - & - & 1.7 & 1.5 & 5.5 & 3.4 & 5.0 & 4.5 & 4.6 & 5.2 \\
ND/SD & - & - & - & - & - & - & - & 6.7 & 1.2 & - & 1.4 & 2.9 \\
Other & 0.5 & 0.5 & 0.4 & 0.8 & 0.3 & 0.5 & 0.7 & 1.0 & 1.0 & 2.6 & 1.7 & 2.7 \\
Turnout & 88.3 & 90.8 & 91.8 & 90.7 & 91.4 & 89.9 & 86.0 & 86.7 & 86.8 & 81.4 & 80.1 & 82.0 \\
\hline
\end{tabular}

Source: for 1970: Arter (1999a); for 1973-2002: Statistiska centralbyrån (2004); for 2006: val.se Notes: 1. In 1985 the Centre Party and the Christian Democrats formed an electoral alliance.

2. After 1990, the party used the label VP.

3. The abbreviation KDS has also been used for Christian Democrats.

4. 1991 and 1994: Ny Demokrati, afterwards Sverigedemokraterna. 
The centre-right parties' share (M, C, FP and later also KD) is highly volatile, supporting the arguments of a divided bourgeois camp in Sweden (e.g. Arter 1999a, 1999b; Kitschelt 2001a). The Swedish Left Party, the former communist party, remains in a rather narrow interval between 4.5 and 6 percentage points, with the exception of the extraordinary 1998 election (see below).

Summing up, support for the Swedish social democrats is rooted in a particular social stratum, in line with Chapter 2's theoretical arguments on the role of decommodifying social policies for social democratic voter alignments; and the party has clearly been the dominant party. Next I will describe the SAP's policy during the 1990s, a time when Sweden was hurt by an economic crisis and the SAP reacted with cutbacks and welfare state reforms. The policy will be situated into the commodification framework outlined in Chapters 2 and 3.

\subsection{The Third Road, crisis responses and welfare state reforms in the 1980 s and $1990 \mathrm{~s}$}

As mentioned, the SAP underwent an ideological and programmatic transformation in the form of its Third Road paradigm (Den tredje vägen), developed under finance minister Kjell-Olof Feldt and his collaborators during the 1980s (Feldt 1985; Pontusson 1992a, 1992b). However, unlike other social democratic parties that transformed themselves using Third Way agendas, the policy change was limited to economic and fiscal policy and did not affect the SAP's welfare policy, which was actually partly expanded (cf. Palme \& Wennemo 1998; Starke 2008: 169; Huo 2009: 70). While the name is reminiscent of the 'Third Way', the approach captured different policy areas from those addressed by the Third Way agendas of the SAP's various sister parties. Moreover, the Third Road emerged in the 1980 s, but did not serve as the ideological background to or blueprint for the welfare state reforms of the 1990 os.

Briefly, the Third Road implied a departure from the party's traditional instruments in economic, monetary and fiscal policy, as supply-side economics, wage restraint and capital market liberalisation became new policy instruments. The main goals of this policy change were to enhance the competitiveness of Swedish industry, increase investments and create balanced economic growth (Pontusson 1992a, 1992b; Huber \& Stephens 2001: 242ff; Huo 2009: 275ff). The SAP implemented its new Third Road stance when it was in government between 1982 and 1991, which 
mainly implied market liberalisation, the privatisation of publicly-owned enterprises and companies, a shift to supply-side economics and an antiinflationary monetary policy (Pontusson 1992a, 1992b: 115ff). This did not shield Sweden from an economic crisis in the late 1980s, with large budget deficits and growing unemployment rates that the SAP had to tackle.

The SAP minority government responded by implementing austerity packages and tax reforms with the support of the Liberal Party in 1990, but also by engaging in compensatory measures in social policy (Palme \& Wennemo 1998: 14). Although these packages reduced the replacement rates of sickness insurance (ibid: 13), they did not contain fundamental labour market reforms or cuts (Huber \& Stephens 2001: 243f; Arter 2003: 89f). In the 1991 elections the SAP suffered defeat due to the unpopular cutbacks and the deteriorating economic situation. A centre-right government led by the Moderate Party's leader Carl Bildt took over.

The new centre-right government engaged in austerity politics and a restructuring of the welfare state in line with the coalition parties' political views (Bergqvist \& Lindbom 2003: 390; Starke 2008: 171). The austerity measures included a reduction of the replacement rates for sickness, parental leave and unemployment insurance from 90 to 80 per cent, which was supported by the SAP (Palme \& Wennemo 1998: 16ff; Timonen 2003: 95). Moreover, waiting days for sickness (one day) and unemployment insurance (five days) were re-introduced. Indexation rules for both the universal and the earnings-related pension were moderately changed for the years 1993 to 1996 through non-decisions.

The bourgeois coalition transformed the existing Ghent system of unemployment insurance into a publicly run and mandatory unemployment scheme which did not imply any retrenchment, but was characterised as an attack on the trade unions' and SAP's power resources (Merkel et al. 2008: 168). The centre-right government further introduced labour market programmes for the young and long-term unemployed to fight unemployment. The social democrats were against these programmes because of tighter eligibility criteria and the abolition of the income maintenance principle. The programmes for the long-term unemployed were approved by the SAP, given their non-recommodifying character, as they re-qualified the unemployed for benefits and focused on education and requalification (Timonen 2003: 102). In the 1994 election, the social democrats regained power after promising to withdraw some of the cutbacks in welfare schemes (Merkel et al. 2008: 161).

The organisational reform of the unemployment insurance was immediately repealed and the union-administered Ghent scheme reinstalled 
(Starke 2008: 171). Other minor reforms concerning labour market regulations were also reversed by the new social democratic government (Bergh \& Erlingsson 2009: 77). However, the SAP stuck with the reductions in the replacement rates of the major social security schemes and the modified indexation rules implemented by its centre-right predecessor, in accordance with its primary aim to consolidate the budget. This was not in line with the SAP's decommodification aspiration, but was accompanied by other measures in the 1994 austerity package stressing two other social democratic core principles, egalitarianism and solidarity. ${ }^{5}$ In cooperation with the Left Party, the SAP implemented higher taxes on capital gains, wealth, property and a supplementary 5 per cent tax on high incomes labelled a 'solidarity tax' (Merkel et al. 2008: 161f). As the budget deficit was still considerable by the end of 1994, the SAP demanded further consolidation measures. The Left Party opposed them, so the SAP cancelled its cooperation with the Left Party and shifted to the Centre Party as its new partner for consolidation measures and welfare reforms in the remainder of the electoral term 1994-98 (Arter 2002: 11f; Särlvik 2002: 258f; Merkel et al. 2008: 162f).

In 1995, the legislative coalition between the SAP and the Centre Party implemented a further reduction of the replacement rate of all welfare benefits from 80 to 75 per cent, to come into effect in 1996. Due to fierce resistance from the trade unions, the measures only stayed in effect temporarily and the replacement rates returned to the previous level of 80 per cent in September 1997, as promised (Palme \& Wennemo 1998: 27ff; Timonen 2003: 95). ${ }^{6}$ In addition, benefits for the first 100 days of unemployment were increased (Huo 2009: 209).

Other proposals were aimed at tightening the eligibility criteria for unemployment insurance, which again met with fierce resistance from the unions and the unemployed. The proposals were designed to increase the qualification period for benefit entitlements, shorten the eligibility period and manipulate the calculation rules for the benefits, implying lower benefits (Timonen 2003: 96f). Given the proposals' unpopularity and the public resistance from the unions, the SAP finally dropped the proposals, which would have meant considerable recommodification. The SAP only managed to limit the eligibility period to three years, a fourth year being contingent on participation in active labour market or qualification programmes (Merkel et al. 20o8: 168). But even this reform was postponed to 2001 when unemployment decreased sharply.

Especially in the period between 1995 and 1999, the SAP government maintained and expanded the Swedish tradition of ALMPs. Its record 
in this area was balanced, however. On the one hand, the new measures aimed to upgrade and qualify the labour force in times of high unemployment and via wage subsidies providing long-term unemployed with public service employment or private sector employment. On the other hand, young unemployed people (under 25) faced tighter eligibility criteria, as the programmes' compensation was not related to previous income levels or unemployment benefit levels, but reflected a flat-rate activation benefit, which could be supplemented by social assistance (so-called utvecklingsgaranti). Furthermore, the mandatory participation did not (re-)qualify the unemployed for unemployment benefits, as previous legislation had done. Both aspects are at odds with traditions in Swedish ALmP (see Hort 2001: 259; Timonen 2003: 96, 102f), ${ }^{7}$ but these measures were targeted at the margins of the labour market, not the core labour force.

Even though the focus here is on labour market policy, another major reform needs to be discussed. ${ }^{8}$ In the 1990 s, Sweden's pension system was reformed to cope with the future demographic challenge. The new measures were put into operation under the bourgeois coalition (1991-94), and it was up to the SAP government to fully implement the reform. The measures had to be implemented gradually and required long transition phases, even though they had been characterised as fundamental and path-breaking for Sweden. Among the major features, indexation was changed to wages, inflation and demography and not only to inflation, as before. Pensions are now calculated based on lifetime contribution records rather than on the best 15 years of a person's working history; this will likely benefit workers and lower white-collar employees. Retirement age was made more flexible. The flat-rate pension became means-tested, but a guaranteed pension partly financed by employers was introduced as a supplementary scheme to secure the high degree of universalism (Merkel et al. 2008: 175). Finally, a residence requirement of 40 years was introduced, which favours Swedish wage earners and disfavours immigrants.

The pension reform has generally not been characterised as an outright retrenchment or a break with the SAP's commitment to welfare, but as an adaption to demographic changes in the coming decades (Palme \& Wennemo 1998: 2off; Anderson \& Meyer 2004; Bergqvist \& Lindbom 2007). The level of expenditure is expected to be the same under standard assumptions of economic development, and the 1998 and 1980 replacement rates do not differ considerably (Palme \& Wennemo 1998: 25; Lindbom 2001). The contents of the reform have been evaluated as being in continuity with the existing goals and attributes of Swedish social democ- 
racy, the Swedish pension system and the Swedish welfare state more generally (Anderson \& Meyer 2004; Bergqvist \& Lindbom 2007: 394). Although the reforms have some recommodifying aspects, as the generosity of pensions became dependent on previous labour market participation, this did not reflect a significant departure from the SAP's stance on social policy. Traditionally, highly decommodifying schemes require previous labour market participation, and this is in accordance with the SAP's productivity-centred stance. Furthermore, the redistributive elements in the pension reforms favour the SAP's blue-collar core constituency (Anderson \& Meyer 2004: 153). Since its implementation, the pension reform has been a non-issue in election campaigns (ibid: 156). The path-breaking Swedish pension reform does not represent a particular Third Way element or have strong elements of recommodification that are contrary to the interests of the social democratic core constituency, and will not be discussed further in this chapter.

In 1998, Sweden's economic situation began to improve significantly and the budgetary crisis was over. Nevertheless, the SAP was punished by the electorate in the 1998 election, but stayed in office. With the 19982002 electoral term, the SAP returned to an expansive strategy concerning the welfare state, especially by extending social services. Except for the reform of the unemployment eligibility period to come into force in 2001, encompassing labour market or welfare state reforms indicating recommodification were not implemented. The SAP's moderate labour market reforms appear to have been a response to a serious economic crisis rather than a sign of a significantly changed stance on the welfare state. Table 7.3 provides an overview of reforms actively implemented by the SAP as governing party (1994-2002), or at least supported during the years in opposition (1991-94). As outlined in Chapter 3, the reforms are classified based on the framework developed by Clasen \& Clegg (2007). Briefly stated, the framework classifies labour market reforms in terms of conditionality; that is, whether benefit claimants have to fulfil few or many criteria to qualify for benefits as a consequence of a legislative change.

The summary of the labour market and welfare state reforms reveals that some reforms implied a certain recommodification, as eligibility criteria have been tightened and lower benefit levels have been introduced. Nevertheless, most of these measures can be characterised as moderate, as few waiting days and still remarkably high replacement rates of 80 per cent do not suggest a considerable degree of recommodification. ${ }^{9}$ 
Table 7.3 Classification of labour market reforms introduced or supported by SAP, 19912002

\begin{tabular}{|c|c|c|c|}
\hline Year and legislation & Reform (status quo in brackets) & $\begin{array}{l}\text { Level of con- } \\
\text { ditionality }\end{array}$ & $\begin{array}{l}\text { Direc- } \\
\text { tion }\end{array}$ \\
\hline $\begin{array}{l}\text { 1992/1993: Crisis } \\
\text { agreement of bour- } \\
\text { geois government and } \\
\text { SAP }\end{array}$ & $\begin{array}{l}\text { Income replacement level of social security } \\
\text { schemes decreased from } 90 \text { to } 80 \text { per cent }\end{array}$ & $\begin{array}{l}\text { Eligibility and } \\
\text { entitlement }\end{array}$ & $\mathrm{R}$ \\
\hline 1993 & $\begin{array}{l}\text { Introduction of } 1 \text { waiting day for } \\
\text { sickness insurance and } 5 \text { waiting days for } \\
\text { unemployment insurance (abolished during } \\
\text { 1980s) }\end{array}$ & $\begin{array}{l}\text { Eligibility and } \\
\text { entitlement }\end{array}$ & $\mathrm{R}$ \\
\hline $\begin{array}{l}\text { 1993: } \\
\text { Arbetslivsutveckling } \\
\text { (ALU) }\end{array}$ & $\begin{array}{l}\text { Labour market development programme } \\
\text { for long-term unemployed with focus on } \\
\text { re-qualification; programmes also re-entitled } \\
\text { persons concerned for unemployment benefits }\end{array}$ & $\begin{array}{l}\text { Eligibility and } \\
\text { entitlement }\end{array}$ & $\mathrm{D}$ \\
\hline 1993-98 & $\begin{array}{l}\text { Non-adjustment of maximum unemployment } \\
\text { benefits (regular adjustment to average wage } \\
\text { growth) }\end{array}$ & $\begin{array}{l}\text { Eligibility and } \\
\text { entitlement }\end{array}$ & $\mathrm{R}$ \\
\hline 1995 & $\begin{array}{l}\text { Changed rules concerning compensation in } \\
\text { ALMP }\end{array}$ & $\begin{array}{l}\text { Behaviour/ } \\
\text { Conduct }\end{array}$ & $\mathrm{R}$ \\
\hline $1995 / 6$ & $\begin{array}{l}\text { Replacement rate of unemployment and other } \\
\text { social security schemes reduced to } 75 \text { per cent } \\
\text { (80 per cent }\end{array}$ & $\begin{array}{l}\text { Eligibility and } \\
\text { entitlement }\end{array}$ & $\mathrm{R}$ \\
\hline 1997 & $\begin{array}{l}\text { Replacement rate of unemployment and other } \\
\text { social security schemes increased to } 80 \text { per cent } \\
\text { (75 per cent in 1996/97) }\end{array}$ & $\begin{array}{l}\text { Eligibility and } \\
\text { entitlement }\end{array}$ & $\mathrm{D}$ \\
\hline 1997 & $\begin{array}{l}\text { Tighter eligibility criteria for unemployment } \\
\text { insurance; benefit entitlement conditional } \\
\text { upon } 26 \text { weeks of work in the last } 12 \text { months } \\
\text { or } 450 \text { hours of work over an uninterrupted six- } \\
\text { month period (previously } 20 \text { weeks) }\end{array}$ & $\begin{array}{l}\text { Eligibility and } \\
\text { entitlement }\end{array}$ & $\mathrm{R}$ \\
\hline 1997 & $\begin{array}{l}\text { Basic and maximum amount of unemployment } \\
\text { benefit increased }\end{array}$ & $\begin{array}{l}\text { Eligibility and } \\
\text { entitlement }\end{array}$ & $\mathrm{D}$ \\
\hline 1997 & $\begin{array}{l}\text { Increased benefits for first } 100 \text { days of } \\
\text { unemployment }\end{array}$ & $\begin{array}{l}\text { Eligibility and } \\
\text { entitlement }\end{array}$ & $\mathrm{D}$ \\
\hline \multirow[t]{2}{*}{1997} & $\begin{array}{l}\text { Early retirement option for } 63 \text { - and 64-year-old } \\
\text { public employees }\end{array}$ & $\begin{array}{l}\text { Eligibility and } \\
\text { entitlement }\end{array}$ & $\mathrm{R}$ \\
\hline & $\begin{array}{l}\text { Abolition of longer eligibility period for } 50-54 \\
\text { year-olds }\end{array}$ & $\begin{array}{l}\text { Eligibility and } \\
\text { entitlement } \\
\text { Behaviour/ } \\
\text { Conduct }\end{array}$ & $\mathrm{D}$ \\
\hline
\end{tabular}


Table 7.3 Classification of labour market reforms introduced or supported by SAP, 19912002

\begin{tabular}{|c|c|c|c|}
\hline Year and legislation & Reform (status quo in brackets) & $\begin{array}{l}\text { Level of con- } \\
\text { ditionality }\end{array}$ & $\begin{array}{l}\text { Direc- } \\
\text { tion }\end{array}$ \\
\hline $\begin{array}{l}\text { 1998: } \\
\text { Utvecklingsgaranti }\end{array}$ & $\begin{array}{l}\text { Mandatory participation in labour market } \\
\text { programmes for young unemployed under } \\
25 \text { after } 100 \text { days of unemployment; no (re-) } \\
\text { qualification for unemployment benefits } \\
\text { possible (non-mandatory before; participation } \\
\text { requalified for benefits) }\end{array}$ & $\begin{array}{l}\text { Eligibility and } \\
\text { entitlement } \\
\text { Behaviour/ } \\
\text { Conduct }\end{array}$ & $\mathrm{R}$ \\
\hline $1997 / 2001$ & $\begin{array}{l}\text { Tighter eligibility criteria for unemployment } \\
\text { insurance came into effect in } 2001 \text {; eligibility } \\
\text { period for unemployment benefits shortened } \\
\text { to three years; a fourth year on benefits } \\
\text { is contingent on participation in ALMP or } \\
\text { qualification programmes }\end{array}$ & $\begin{array}{l}\text { Eligibility and } \\
\text { entitlement }\end{array}$ & $\mathrm{R}$ \\
\hline 2000 & $\begin{array}{l}\text { Activation guarantee for long-term } \\
\text { unemployed introduced; eligibility contingent } \\
\text { on participation in labour market training } \\
\text { programmes or qualification measures of at } \\
\text { least } 6 \text { months duration }\end{array}$ & $\begin{array}{l}\text { Eligibility and } \\
\text { entitlement } \\
\text { Behaviour/ } \\
\text { Conduct }\end{array}$ & $\mathrm{R}$ \\
\hline 2002 & $\begin{array}{l}\text { Maximum amount of unemployment benefit } \\
\text { increased }\end{array}$ & $\begin{array}{l}\text { Eligibility and } \\
\text { entitlement }\end{array}$ & $\mathrm{D}$ \\
\hline
\end{tabular}

Sources: Palme \& Wennemo (1998); Lindbom (2001, 2002, 2007); Palme et al. (2002); Timonen (2003); Merkel et al. (2008: chap. 8); Starke (2008); Huo (2009); Christiansen et al. (2010). $\mathrm{R}$ : recommodification, D: decommodification.

The same is true for the qualification period of 26 weeks of work (previously 20 weeks) to qualify for unemployment benefits and an eligibility period of three years before mandatory activation for ordinary wage earners takes place (Palme \& Wennemo 1998: 33). ${ }^{10}$ Other measures were already temporary or counterbalanced by later reforms, such as the increase in the basic and maximum amounts of unemployment benefits after the immediate crisis had passed. To assess how these measures have influenced the degree of income maintenance in the Swedish case, Table 7.4 provides an overview of the replacement rates.

Table 7.4 Summary measures of benefit entitlements for Sweden, 1989-2003

\begin{tabular}{lllllllll}
\hline & 1989 & 1991 & 1993 & 1995 & 1997 & 1999 & 2001 & 2003 \\
\hline Replacement rate (Scruggs) & 87 & 88 & 90 & 81 & 73 & 72 & 70 & 76 \\
\hline
\end{tabular}

Source: Scruggs (2006). Bold figures indicate post-reform years. 
The figures follow the logic of the reforms quite closely with a time lag, as the average replacement rate decreased from about 90 per cent in the early 1990 s to 80 and later 70 per cent, and then recovered in line with the SAP's policy described above. The figures also fit Lindbom's claim (2001: 142f) that the lower replacement rates between 1993 and 1998 were the effect of non-indexation, was a highly non-transparent way of cutting back. They indicate quite a bit of recommodification, but at a very high base level. On that score, the replacement rates calculated by Lindbom (2001) show that the level of generosity of Swedish unemployment insurance in 1998 was the same as it had been in 1980. Thus, the SAP's policy cannot be regarded as outright retrenchment in a quantitative sense, as some of the cuts during the crisis were counterbalanced afterwards. Furthermore, the replacement rates remained high compared with those of other countries and did not drop considerably below the replacement rates of the 1980 .

On balance, the SAP implemented some reforms and measures pointing to limited recommodification during an economic crisis, but in line with previous assessments and interpretations, the reforms were moderate and often temporary compared to the three other cases, as we will see below. The SAP did not fundamentally break with its social policy principles or with the main pillars of the Swedish welfare state: there were no fundamental ideological transformations, path-breaking policy changes or big bang reforms implying considerable recommodification. ${ }^{11}$ The SAP's policy is to a large extent consistent with the traditional social democratic principles outlined in Chapter 2 and has been characterised as coherent with the party's programmatic stance (Anderson \& Meyer 2004; Merkel et al. 2008: 18off). After the reforms, the generosity of the Swedish welfare state remained the same, or even greater, than it had been in 1980, before Sweden was hit by two economic crises (Lindbom 2001, 2002, 2007).

Most commentators argue that the reforms neither dismantled nor retrenched the Swedish welfare state, but simply responded to the deteriorating economic situation (Hort 2001; Lindbom 2001; Timonen 2003; Merkel et al. 2008: chap. 8; Starke 2008: chap. 7; Bergh \& Erlingsson 2009). Unlike in the other cases, no encompassing reforms implying tighter eligibility criteria or work obligations have been introduced in Sweden (cf. Hort 2001: 262). The reforms did not fundamentally enhance conditionality for the core workforce in terms of claiming benefits, and Swedish labour market policies are still a civilised version of workfare (Hort 2001). Some of the measures reflect incremental changes that have to be seen 
in light of traditions of active labour market policies and the workfare element that always played a role in Swedish welfare policies and the SAP's commitment to social policy (Bergqvist \& Lindbom 2003; Timonen 2003: 7). Most of these reforms, which introduced harsher conditions and tighter criteria, concerned the fringes of the labour market (e.g. labour market entrants, immigrants, or social assistance recipients) rather than the Swedish labour market insiders; that is, the SAP's core voter base (Lindvall \& Rueda 2012). The same claim has been made with regard to new ALMP schemes (Huo 2009: 112). ${ }^{12}$

In sum, we would expect the electoral setback and the extent of dealignment for the SAP to be more limited than for its British, Danish and German sister parties. We would expect dealignment to mainly take place in the period between 1994 and 1998, after which we would expect the SAP to recover, when traditional social democratic principles regained strength. This is further discussed in the following section on party competition in Sweden in the period between 1991 and 2006.

\subsection{Party competition in Sweden, 1991-2006}

The Swedish party system has traditionally been characterised as that which most closely matches the Scandinavian five-party system consisting of two left parties - the hegemonic social democratic party SAP and the small far-left communist party (Vänsterpartiet Kommunisterna, VPK) - and three middle-sized bourgeois parties, the Centre Party (Centerpartiet, C), the Liberal People's Party (Folkpartiet, FP) and the Moderate Party (Moderaterna, M), a secular conservative party (Arter 1999b; Särlvik 2002). Social democratic minority governments were the norm in the last four decades of the 2oth century (Steffen 2006: 92). After the 1976 election, the party system assumed an increasingly bipolar structure consisting of a left and a centre-right bloc, even though the Centre and Liberal Party occasionally cooperated with the SAP on legislation. It was only in the 1990s, when the five-party system was permanently enlarged by two small parties, the Greens (Miljöpartiet de Gröna, MP) and the Christian democrats (Kristdemokraterna, KD) ${ }^{13}$ that these parties were able to pass the 4 per cent threshold in two consecutive elections. Far-right parties had no lasting impact. The New Democrats (Ny Demokrati, ND) gained parliamentary representation between 1991 and 1994, but then disappeared. The recently emerging Sweden Democrats (Sverigedemokraterna, SD) were not able to pass the electoral threshold during the period under 
review. ${ }^{14}$ Considering these features of party competition in Sweden, the Left Party should be the most dangerous challenger in terms of the framework on party competition. I will discuss the role of other parties briefly.

Historically, the Left Party was an orthodox communist party with a small but stable core constituency of blue-collar workers that secured parliamentary representation thanks to the 'comrade vote' mentioned above (Arter 2002: 14). ${ }^{15}$ In recent decades, the party underwent a process of modernisation, including a shift towards a left socialist stance and a broader electoral programme emphasising ecological and feminist issues (Arter 2002, 2003; Spier \& Wirries 2007: 8off), although Arter (2002: 24) claims that its policy agenda changed little. Since striking 'Communist' from the party name in 1990, the party has run under the label 'Vänsterpartiet' (the Left Party), which will be used during the remainder of this chapter.

As mentioned, the Left Party cooperated with the SAP on the first crisis packages, as it legislatively supported cutbacks and tax increases to stabilise the budget. After the cooperation with the SAP ended in 1995 and the social democrats collaborated with the Centre Party on further austerity measures and social security reforms, the Left Party found itself in a more favourable opportunity structure. Given the perceived rightward shift of the SAP due to policies of fiscal prudence and cooperation with bourgeois parties, the Left Party capitalised on the expanded policy space on the political left (Arter 2002; Blomqvist \& Green-Pedersen 2004). The party could now act as the defender of the Swedish welfare state and appealed to disaffected social democratic voters with a distinct reform-averse stance (Arter 2002: 11, 2003: 93; Blomqvist \& Green-Pedersen 2004: 606). Arter (2002) has - somewhat provocatively - characterised the party strategy as a social democratisation of the Swedish Left Party. The party developed a more oppositional profile before the 1998 election and represented the type of dangerous left-wing challenger described in Chapter 2, at least for the 1998 elections.

After the SAP's disastrous result in the 1998 election, the social democrats were able to remain in office thanks to a legislative coalition with the Left Party and the Greens (Särlvik 2002: 258f; Madeley 2003: 165f). In other words, the Left Party rescued the government, whose policies it had previously fiercely criticised and whose supporters it had absorbed (Spier \& Wirries 2007: 114). The legislative coalition implied no direct policies in return for the cooperation of the left (Steffen 2006: 93). As mentioned above, the SAP returned to welfare state expansion in the 1998-2002 electoral term after the economic crisis. These measures allowed the SAP to 
claim all the credit, not to share it with potential coalition partners. The Left Party's strategy to back a SAP minority government without getting something in return has been characterised as useless, and the party was seen as a Babylonian captive of the SAP (Spier \& Wirries 2007: 84; Merkel et al. 2008: 160). Thus we could expect the Left Party to make temporary gains in the 1998 elections as a consequence of the austerity policies under the SAP government. However, due to the temporary nature of the reforms and the Left Party's strategic mistakes, which damaged its credibility after 1998, we would not expect the party to foster a lasting realignment of social democratic core voters.

Turning to the other type of serious challenger, authoritarian rightwing parties, we can rule out beforehand that these parties benefited from the SAP's reforms after 1994 or the financial crisis in the 1990 s more generally. During the 1991-94 electoral term, when a bourgeois four-party coalition governed Sweden, the right-wing New Democrats were represented in parliament after gaining 6.7 per cent of the vote in the 1991 election. However, the party failed to pass the threshold in 1994 after internal turmoil, and virtually disappeared (see Rydgren 2002). This party was not a credible challenger to the SAP during the period of welfare state retrenchment and crisis management and is not further addressed in the analysis. Similarly, the Sweden Democrats were not an effective challenger before 2006, when the party gained 2.9 per cent of the votes and came close to parliamentary representation. The party only gained in importance after the period of social democratic crisis management and after four years of bourgeois government, when it passed the 4 per cent threshold in the 2010 election. In other words, right-wing parties did not challenge the SAP during the period of investigation.

We should not expect the other parties that competed with the social democrats during the period under review to be serious challengers for core constituency voters. Beginning with the main bourgeois party, the Moderates, I would not expect this party to make any systematic gains among social democratic core voters given its distinct market-liberal agenda and proposals for welfare and tax cuts in the period between 1994 and 2002. This changed after 2002 under the new leader, Fredrik Reinfeldt, as the party softened its market-liberal programme (Agius 2007; Oscarsson \& Holmberg 2008). The same applies, to a similar degree, to the Liberal Party, which joined forces with the Moderates in opposition to form a united bourgeois bloc after 1998.

To some extent, the Centre Party has been an option for moderate social democratic core voters, as suggested in Table 7.1. Nevertheless, we 
would not expect the party to have sufficient credibility to attract social democratic voters, not to mention reach a realignment, given its support for various crisis packages and the retrenchment of social benefits after 1991. The fact that the party was willing to join a coalition with the welfare-critical Moderate Party during the period of investigation further detracts from its ability to attract dissatisfied SAP voters.

The Greens are a left-libertarian party that appeals to the highly-educated new middle class, and are thus not seen as a credible contender for social democratic core voters. The only small party that we might expect to make some gains during the period of investigation is the Christian Democrats (KD). Previous work on the KD claims that the party is normally not able to gain votes from the SAP (or other major parties), and the party has traditionally had its stronghold among middle-class officials (Karvonen 1996: 133). This changed in 1991 when the party attracted other occupational groups, when it uncharacteristically showed a pronounced interest in social welfare (Karvonen 1996: 137). Unfortunately, the party has received little attention in the literature; only the descriptive data in Keman et al. (2006) shows an accentuation of the KD's welfare profile over time. A tentative presumption is that the party may have profited from the SAP's response to the crisis. The party did not have dirty hands, since it did not participate in the crisis agreements between the established parties and it has a profile on welfare. Then again, the party may have had a harder time creating lasting ties to social democratic core voters, as it increasingly affiliated with the reform-minded bourgeois camp after 1998. This will be examined empirically.

On balance, the Swedish case confirms my control case with respect to the electoral consequences of its welfare reforms. Given that the reforms have been characterised as moderate and largely in line with Sweden's and the SAP's social policy traditions, we can expect the electoral effects to be more limited than in the other cases. Moreover, there should be no lasting realignment of social democratic core constituents with other parties. As the most likely competitor, we would expect the Left Party to make gains in 1998 among the SAP's core electorate, but I would not expect lasting gains, given the nature of the reforms (as well as the SAP's and the Left Party's strategies in the period under investigation). Other possible effects concern the Christian Democrats, but this requires empirical investigation, as the limited literature on this party does not allow us to construct a well-grounded hypothesis. 


\subsection{Data}

The data used in the empirical analysis come from three different sources: the Swedish Election Studies, the Riks-SOM opinion surveys and the exit polls for the Swedish Election Studies. The reason for using three data sources is the lack of variables on the reforms during the 1990 s in the election studies. The annually conducted Riks-SOM surveys contain items on labour market reform proposals that allow us to measure the respective attitudes in the descriptive part, but do not contain a vote recall question for electoral behaviour. The exit polls for the 1998 and 2002 election allow us to analyse voter migration patterns for the two elections and are used in the logistic regression model for the 1998 election.

The dependent variable in the logistic models is reported party choice for all relevant parties, whereas non-voting could not be separated in all analyses due to data limitations. The independent variables are the voter group, as described in Chapter 3, and variables that capture attitudes towards labour market policies as proxies for the respondents' attitudes towards the reforms.

\subsection{Analysis}

Attitudes towards labour market reform proposals and party shares

I first present attitudes towards several reform proposals and assessments of the SAP government's labour market policy, to show that such policies are not endorsed by the SAP's core constituency. The 1996 and 1998 Riks-som surveys contain the respective items, and the data sources thus cover the period when SAP engaged in crisis management. Some of the proposals were actually implemented as reforms before the 1998 election. Other proposals, such as the limited eligibility period for unemployment benefits, were not introduced by the SAP. However, the results indicate that the SAP's core constituency heavily opposed the proposals and they were ultimately dropped by the SAP. The voter groups' attitudes towards these proposals are presented in Table 7.5.

The first item on whether ALMP should increasingly be used to fight unemployment is in line with the earlier claims about the SAP's productivity-centred tradition. The social democratic core constituency is more enthusiastic about the proposal of increasingly using ALMP measures during the crisis. This indicates that the early accentuation of ALMP and the SAP's work-centred ethos are reflected in the respective attitudes among 
its core voter base, which does not oppose such measures. Moreover, as described above, the SAP indeed extended the use of ALMP during the period of investigation.

In contrast, proposals that clearly imply retrenchment and recommodification, such as lower unemployment benefits, shortened eligibility periods and a reduced public sector, met with fierce opposition among the

Table 7.5 Attitudes towards labour market reform proposals by voter group, percentage points

\begin{tabular}{|c|c|c|c|c|}
\hline \multirow[b]{2}{*}{ Voter group } & \multicolumn{4}{|c|}{ Increased use of ALMP 1996 [V143] } \\
\hline & Good proposal & Neither & Bad proposal & Total \\
\hline Non-core constituency & 40.3 & 28.4 & 31.3 & 100 \\
\hline Core constituency & 48.1 & 25.0 & 26.9 & 100 \\
\hline \multirow[t]{3}{*}{$\mathrm{N}=1,426$} & & & $\mathrm{Chi}^{2}: 8.8$ & $\mathrm{P}<.05$ \\
\hline & \multicolumn{4}{|c|}{ Lower unemployment benefits 1996 [V146] } \\
\hline & Good proposal & Neither & Bad proposal & Total \\
\hline Non-core constituency & 18.3 & 27.1 & 54.6 & 100 \\
\hline Core constituency & 12.5 & 14.2 & 73.3 & 100 \\
\hline $\mathrm{N}=1,430$ & & & $\mathrm{Chi}^{2}: 56.4$ & $\mathrm{P}<.00$ \\
\hline
\end{tabular}

Reduce the public sector 1996 [V127]

\begin{tabular}{lcccc} 
& Good proposal & Neither & Bad proposal & Total \\
\hline Non-core constituency & 33.1 & 21.7 & 45.2 & 100 \\
Core constituency & 19.2 & 19.9 & 60.9 & 100 \\
$\mathrm{~N}=1,409$ & & & $\mathrm{Chi}^{2}: 43.1$ & $\mathrm{P}<.00$ \\
\hline
\end{tabular}

Limited eligibility period for unemployment benefits 1998 [V270]

\begin{tabular}{lcccc} 
& Good proposal & Neither & Bad proposal & Total \\
\hline Non-core constituency & 32.5 & 27.4 & 40.1 & 100 \\
Core constituency & 22.5 & 20.6 & 56.9 & 100 \\
$\mathrm{~N}=1,462$ & & & $\mathrm{Chi}^{2}: 41.5$ & $\mathrm{P}<.00$ \\
\hline
\end{tabular}

Attitude towards labour market policy and fight against unemployment 1998 [V245]

\begin{tabular}{lcccc} 
& Good policy & Neither & Bad policy & Total \\
\hline Non-core constituency & 13.3 & 24.3 & 62.4 & 100 \\
Core constituency & 19.2 & 29.9 & 50.9 & 100 \\
$\mathrm{~N}=1,460$ & & & $\mathrm{Chi}^{2}: 20.5$ & $\mathrm{P}<.00$ \\
\hline
\end{tabular}

Source: Own calculations based on Riks-SOM surveys 1996 \& 1998. 
social democratic core voter base, but found more approval among other voters. This confirms the expected social policy preferences of the social democratic core voter base, as theorised in Chapter 2, since proposals leading to recommodification are refused.

The last item reveals that while non-core constituents were even more sceptical about the SAP's labour market policy in 1998, every second respondent from the core constituency was not satisfied with the social democrats' policy in this area. This confirms that the crisis management measures were unpopular in general, but were not endorsed by the social democratic core constituency. This may explain why the SAP was unable to retain its strong support from 1994 in the 1998 election, and why the Left Party made gains. Next, I will look at descriptive statistics examining the electoral strengths of the parties among the voter groups between 1991 and 2006.

Table 7.6 shows that the SAP did not suffer a pronounced decline among the party's traditional core constituency during the period of investigation. The party mobilised almost four out of ten voters from this segment in all elections between 1991 and 2006, expect for the extraordinary result in 1994, when more than 60 per cent supported the social democrats after four years of bourgeois government. Nevertheless, the level of support among core voters in 2006, when the party lost office, was not fundamentally different from that in 1991. On the contrary, there was slightly weaker support among non-core constituents in 2006 and a decline among this voter segment after the 1994 election.

The Left Party, which has been identified as the most serious challenger to the SAP, made considerable gains among the social democratic core constituency. After the SAP engaged in cutbacks and crisis management between 1994 and 1998, the former communists mobilised every seventh social democratic core voter in the 1998 election. However, the support did not last; the vote shares declined in the following two elections, and the support was actually weaker in 2006 than in 1994, in terms of the social democratic core voter base.

Surprisingly, the figures for the Christian Democrats show a similar pattern in the period under review. The support peaks with the 1998 election, but the Christian Democrats were not able to gain a lasting foothold among these voters, as the figures for 1991 and 2006 do not differ dramatically. An important difference from the Left Party is that the variation of the Christian Democrats' vote shares is higher among noncore constituents, whereas the opposite is true for the Left Party. As expected, the latter party is obviously more latter party is obviously more 
Table 7.6 Party shares and non-voting among voter groups, Swedish Riksdag election 1991-2006 (per cent)

\begin{tabular}{|c|c|c|c|c|c|}
\hline Core constituency & 1991 & 1994 & 1998 & 2002 & 2006 \\
\hline SAP & 44.4 & 54.4 & 41.9 & 44.9 & 40.6 \\
\hline Conservatives & 13.4 & 9.6 & 11.1 & 5.9 & 16.4 \\
\hline Left Party & 2.8 & 7.3 & 12.0 & 8.8 & 7.0 \\
\hline Centre Party & 8.2 & 6.4 & 2.7 & 4.1 & 5.3 \\
\hline Liberals & 4.6 & 3.3 & 1.7 & 8.2 & 5.5 \\
\hline Christian Democrats & 6.0 & 3.3 & 8.4 & 6.2 & 4.9 \\
\hline Greens & 2.4 & 3.3 & 3.0 & 4.3 & 4.0 \\
\hline Ny Demokrati/ SD ${ }^{1}$ & 6.9 & 0.8 & - & - & 3.2 \\
\hline Non-voting & 10.6 & 11.0 & 15.8 & 15.6 & 10.0 \\
\hline Non-core constituency & 1991 & 1994 & 1998 & 2002 & 2006 \\
\hline SAP & 25.3 & 33.0 & 26.6 & 27.9 & 22.7 \\
\hline Conservatives & 27.0 & 28.0 & 29.0 & 16.7 & 30.4 \\
\hline Left Party & 3.4 & 4.4 & 7.6 & 5.8 & 5.0 \\
\hline Centre Party & 8.3 & 9.1 & 5.8 & 6.4 & 8.9 \\
\hline Liberals & 11.3 & 10.5 & 5.8 & 18.5 & 8.7 \\
\hline Christian Democrats & 7.8 & 3.9 & 12.6 & 10.4 & 7.9 \\
\hline Greens & 3.7 & 4.5 & 4.7 & 6.1 & 5.9 \\
\hline Ny Demokrati/SD 1 & 6.4 & 1.2 & - & - & 1.0 \\
\hline Non-voting & 6.2 & 5.4 & 7.1 & 7.2 & 7.1 \\
\hline
\end{tabular}

Source: Own calculations based on the figures reported in Oscarsson \& Holmberg (2008: appendix A) and Swedish Election Studies. Figures do not always add up to 100 per cent due to rounding.

Notes: 1. 1991 and 1994: New Democrats; 2006: Sweden Democrats.

dangerous for the SAP's electoral fortunes among its rank-and-file. The vote shares of the other bourgeois parties and the Greens do not show patterns of lasting gains among the SAP's core voter base. Non-voting among core constituents remained between 10 and 15 per cent with no pronounced trend. This will not be discussed specifically in the remainder of the analysis.

The electoral punishment after the crisis, 1994-98

The next step is to model the electoral effects for the two elections where they are especially important, namely the 1998 and 2002 elections. I used 
exit polls for the 1998 Riksdag election and the Riks-som survey of 1998 in the analyses. The first data set has a vote recall question but no explicit item on social policy or labour market policy attitudes, and only one item on assessment of the SAP's policy. The latter allows me to examine the effects of disaffection with the SAP's labour market policy on vote choice in 1998, but unfortunately lacks a vote recall variable. The combined use should nevertheless indicate whether there are clear patterns of electoral effects, in particular whether social democratic core voters shifted to the Left Party in 1998.

Table 7.7 Predicted probabilities of vote choice among voter groups by perception of SAP policy, 1998 election (per cent)

\begin{tabular}{|c|c|c|}
\hline & \multicolumn{2}{|c|}{ Aligned Core Constituency } \\
\hline & $\begin{array}{l}\text { Assessment of policy: } \\
\text { good/neither good nor bad }\end{array}$ & $\begin{array}{c}\text { Assessment of policy: } \\
\text { bad }\end{array}$ \\
\hline SAP & 81.3 & $15.1^{*}$ \\
\hline Moderates & 1.5 & $19.7^{*}$ \\
\hline Left Party & 11.7 & $26.7^{*}$ \\
\hline Christian Democrats & 1.6 & $14.8^{*}$ \\
\hline Centre Party & 0.7 & $2.9^{*}$ \\
\hline Liberals & 0.8 & $6.3^{*}$ \\
\hline Greens & 1.7 & $5.5^{*}$ \\
\hline Other parties & 0.8 & $9.1^{*}$ \\
\hline
\end{tabular}

Source: Predicted probabilities obtained from multinomial logistic regression models using Clarify (Tomz et al. 2003).

Notes: 1. Aligned core constituency is defined as being a worker or a lower white-collar employee and having voted for the social democrats in the previous general election. The number of simulations to obtain the probabilities was set to 1,000. Figures do not always add up to 100 per cent due to rounding. The Swedish data do not include reliable information on non-voting and were thus excluded from the models. * indicates that the party share reported in the right-hand side is significantly distinguishable from the share in the left-hand side at the 0.05 level.

Table 7.7 shows the predicted probabilities from a logistic regression model using the exit polls for the 1998 election. The figures demonstrate that the SAP kept core constituents satisfied, but was punished by those who were dissatisfied, as the shares between the two groups differ significantly by about 65 per cent. As expected, the Left Party had been able to attract disaffected former social democratic core voters, as 
they attracted more than every fourth voter if these conditions applied. The former communists remained the largest party but they stayed weak among non-core constituents, especially if they were dissatisfied with the SAP's policy. This confirms that this party represents the type of left-socialist challenger conceptualised in Chapter 2. The Christian Democrats also gained considerably among core constituents who had supported the SAP in the 1994 election but who had then become dissatisfied. Their share is higher among non-core voters who are sceptical towards SAP's policy (not shown).

While these figures fit quite well into the party shares and their between group variation shown in Table 7.6, one should recall that the item asked respondents about their general assessment of the SAP's labour market policy performance. This may explain the relatively clear and significant differences between the left- and the right-hand panel of the table.

The SAP's recovery and the Left Party's setback, 1998-2002

A further step investigates whether these patterns were reversed, at least partly, with the 2002 election, where the SAP recovered and the Left Party and the Christian Democrats lost a great share of the social democratic core constituents whom they had previously attracted. This would confirm the expectation that the SAP suffered a temporary setback, but not realignment to challengers. As the exit polls for the 2002 election contain no applicable items on policy, it is only possible to examine the voter migration patterns (see Table 7.8). Although it is far from an optimal procedure, the figures in Table 7.8 on voter migration give an indicative picture. In the 2002 election, the SAP was able to keep a large share of those core constituents who had voted for the party in the previous election, and did not lose a considerable share to the Left Party.

The Left Party lost every fourth voter from the social democratic core voter base to the SAP in the 2002 election, and was only able to retain six out of ten voters from this voter segment. The party thus declined in popularity among these voters and was not able to foster a lasting realignment as the SAP regained momentum. The Christian Democrats also lost a considerable share of voters from the social democratic core voter base, as almost every second voter turned to another party. Suprisingly, this benefited the Liberals rather than the SAP. However, this did not substantially damage the SAP's recovery among this voter segment, as the largest 


\begin{tabular}{|c|c|c|c|c|c|c|}
\hline \multirow[b]{2}{*}{$\begin{array}{l}\text { Voter group and party } \\
\text { choice in } 1998 \text { election }\end{array}$} & \multicolumn{6}{|c|}{ Party choice in 2002 election } \\
\hline & SAP & Moderates & Left Party & $\begin{array}{l}\text { Christian } \\
\text { Democrats }\end{array}$ & $\begin{array}{l}\text { All other } \\
\text { parties }\end{array}$ & \\
\hline Non-core constituency & 26.9 & 21.8 & 8.0 & 9.3 & 34.0 & $\begin{array}{c}100 \\
(2,462)\end{array}$ \\
\hline $\begin{array}{l}\text { Non-aligned core } \\
\text { constituency }\end{array}$ & 14.6 & 18.6 & 5.7 & 13.5 & 47.6 & $\begin{array}{c}100 \\
(2,675)\end{array}$ \\
\hline $\begin{array}{l}\text { Core constituency } \\
\text { aligned to SAP }\end{array}$ & 83.5 & 1.5 & 4.8 & 1.8 & 8.4 & $\begin{array}{c}100 \\
(2,193)\end{array}$ \\
\hline $\begin{array}{l}\text { Core constituency } \\
\text { aligned to Left Party }\end{array}$ & 25.3 & 0.3 & 60.1 & 2.1 & 12.2 & $\begin{array}{c}100 \\
(732)\end{array}$ \\
\hline $\begin{array}{l}\text { Core constituency } \\
\text { aligned to Christian } \\
\text { Democrats }\end{array}$ & 9.0 & 6.0 & 1.4 & 55.3 & 28.3 & $\begin{array}{c}100 \\
(367) \\
\text { (total } \mathrm{N}=8,062)\end{array}$ \\
\hline
\end{tabular}

Source: Own calculations based on VALU exit polls 2002.

share of (back-)flow to the SAP came from the Left Party. If we compare Table 7.8 with Table 7.6 , we see that the SAP's adherence to a more traditional social democratic agenda prevented a serious challenger from making lasting gains.

This can be proven by analysing the item on whether respondents favour lower unemployment replacement rates available in the Riks-SOM 2002 data set. Table 7.9 shows vote decisions in the 2002 Riksdag election contingent on voter group and attitudes towards lower unemployment benefits. It captures attitudes towards a reform proposal implying recommodification. The SAP performed best among reform-averse voters in the 2002 election, as every second core voter chose the SAP. In other words, the SAP was still able to attract these voters and had not damaged its welfare image substantially in the years before. The Left Party is strongest among the reform-averse, which is not too surprising. The party also defends welfare schemes, and the previous analyses show that it always had a backing among workers and lower white-collar employees. The Moderates and, to a lesser extent, the Liberal Party attract voters who endorse reduced income compensation in case of unemployment, reflecting the parties' reform-minded images.

The analysis for the 2002 election thus demonstrated that the SAP was able to recapture many of those voters that the party had lost in the previous election, in particular to the Left Party. This means that in line with expectations, no realignment of social democratic core voters took place. 
Table 7.9 Attitudes towards lower unemployment benefits and party choice in 2002 election (per cent)

\begin{tabular}{lcc}
\hline & \multicolumn{2}{c}{ Core Constituency } \\
& Reform-minded & Reform-averse \\
\hline SAP & 37.1 & $50.5^{*}$ \\
Moderates & 12.8 & $3.4^{*}$ \\
Left Party & 4.2 & $11.9^{*}$ \\
Christian Democrats & 5.4 & 2.0 \\
Centre Party & 6.6 & 4.8 \\
Liberals & 15.8 & $9.0^{*}$ \\
Greens & 3.1 & 7.2 \\
Other Parties & 4.6 & 2.2 \\
Non-voting & 10.3 & 8.9 \\
\hline
\end{tabular}

Source: Predicted probabilities from logistic regression model using Riks-SOM 2002 data set.

\subsection{The SAP's electoral fortunes in opposition}

This section discusses some recent developments in Sweden that, at first glance, contradict my arguments: namely, the SAP's disastrous 2010 election and the simultaneous breakthrough of the right-wing Sweden Democrats (Sverigedemokraterna).

In the 2010 Riksdag election, the SAP experienced an electoral disaster, as the party only got 30.7 per cent of the vote, the worst result since the First World War. The party remained in opposition as it failed obtain a majority with its potential coalition partners, the Greens and the Left Party. It seems that the SAP's decline occurred one or two electoral terms later than that of its British, Danish or German sister parties, which lost heavily as a consequence of Third Way reforms. One may speculate that the loss of core constituents and the weakened electoral position of social democratic parties are inevitable in the long run, which would confirm the arguments from the class voting literature.

However, I argue that this does not contradict the book's theoretical arguments for several reasons. First, and most importantly in terms of the book's main claim, the party was not in office during the electoral term 2006-2010 preceding the debacle, and was thus not responsible for any reforms or retrenchment, since a centre-right majority coalition held power.

Second, the Moderates, the SAP's biggest competitor, have become more moderate and have presented themselves as Sweden's 'New Labour 
Party' since 2006 (Agius 2007; Lindbom 2008; Oscarsson \& Holmberg 2008: chap. 4; cf. also www.moderat.se). This has allowed the party to gain a foothold outside its own constituency and to compete with the SAP at eye level, which had not been the case for decades. Third, the SAP's new leader, Mona Sahlin, was unable to gain strong support among the electorate in 2010 in her fight against the popular leader of the Moderates, Fredrik Reinfeldt. On the contrary, she remained quite unpopular (see the polls reported in Dagens Nyheter, 1 April 2010).

Furthermore, the electoral breakthrough of the Sweden Democrats needs to be addressed. In the 2010 election, the party managed to pass the 4 per cent threshold for the first time. The party represents a serious challenger in my framework, as a right-wing authoritarian party that also used a social protectionist agenda in the 2010 campaign. The Sweden Democrats played no role during the SAP's incumbency, but emerged as a nationwide challenger to the established parties under a centre-right government. Hence, the Sweden Democrats' breakthrough is not at odds with my arguments, since it could hardly be the welfare policy of the then oppositional SAP that allowed the Sweden Democrats to win a sufficient number of votes in 2010.

Indeed, there are two more obvious reasons for their successful 2010 campaign. First, under a new leader, Jimmie Åkesson, the party has abandoned its extremist positions of recent years. Second, the party may have successfully targeted those voters that became disaffected with the Swedish taboo on putting immigration and related problems on the political agenda. The latter could be the case, since the political salience of immigration has been limited, as the parties of the centre-right do not mobilise on this issue at all. This is different from Denmark, where both the Danish People's Party and the mainstream bourgeois parties have put the issue on the agenda since the 1990 os (Green-Pedersen \& Krogstrup 2008).

Hence, the breakthrough of the Sweden Democrats is not completely at odds with my theoretical expectations, but has to be explained by factors other than welfare state reforms. Explaining the breakthrough of the Sweden Democrats may be an issue for future research agendas.

\subsection{Conclusion}

The goal of this last case study chapter was to examine the electoral prospects of a social democratic party that did not undergo a transformation under a Third Way agenda and did not introduce path-breaking welfare 
state reforms. I demonstrated that the SAP indeed introduced some welfare state reforms and cutbacks in social security schemes, but the measures were a reaction to the serious economic and financial crisis in Sweden during the 1990s. The reforms were not part of an ideological change, as the SAP retained a more traditional stance in the period under review. The reforms were often temporary and can been characterised as moderate, as they were in line with the SAP's traditional principles of ALMP and workfare. They did not introduce tighter conditionality or restrict eligibility for the core workforce compared to measures introduced by other Third Way social democrats, as the following chapters will demonstrate.

In this case, I expected the social democrats to be able to maintain substantial backing among their core constituency, as the decommodification link was not completely broken. The anticipated electoral effects were a temporary setback after the 1994 election, but not an outright dealignment or realignment of the core constituency. The Left Party was identified as the most serious challenger in accordance with my theoretical framework and was thus expected to benefit from the dissatisfaction with the SAP's crisis management in the 1998 election, but not afterwards.

The empirical analysis met these expectations to a considerable degree. The SAP was not able to retain its extraordinary level of support among core constituents from the 1994 election, as the party was punished in the 1998 election. However, the SAP managed to keep more than four out of ten voters from its core voter base over the period examined, even though the party lost office in the 2006 election. This means that the SAP could still draw on the support of a stable core constituency after having engaged in crisis management during the 1990 s, but not in a transformation towards a Third Way agenda, in contrast to many other social democratic parties. Similarly, the Left Party's support among the SAP's traditional voter base peaked with the 1998 election, but the party was not able to make lasting inroads among these voters. This voter segment turned to the Left Party due to dissatisfaction, but returned to the SAP in the 2002 election. Somewhat surprisingly, the Christian Democrats also benefited from the dissatisfaction with the SAP in 1998, but the gains did not last and the party was even stronger among the non-core constituency in this period, which distinguishes it from the Left Party. This is not completely at odds with the theoretical framework, as the Christian Democrats had some appeal on welfare during the 1990 s, even though the party does not fit into a left-socialist or right-wing authoritarian category. This party may be regarded as a miniature version of the traditionally welfare-minded 
Christian Democratic parties in Continental Europe, at least during the period of crisis management.

In line with expectations, we found neither a dealignment nor a realignment of social democratic core constituents in a case where social democracy stuck to a more traditional agenda. The SAP was at least partly able to maintain the decommodification principle in its social policy. This is not to say that the SAP did not engage in some recommodification, but there was no outright policy change as a consequence of a Third Way agenda.

On balance, the results show that class voting in the Swedish case did not decline. Class is still distinctive when it comes to party choice, as Swedish social democracy still draws on a particular core voter base consisting of workers and lower white-collar employees. The Left Party was an alternative for those voters, since their temporary gains had a strong class base, as shown above. This is in line with the theoretical claim that class-based social policy attitudes structure the logic of party alignments. Similarly, the Moderates attract the upper social strata, as, until recently, they appealed to voters who preferred to see the welfare state dismantled.

This does not mean that there has not been a decline in class voting in Sweden, but it has not declined strongly as a secular societal trend. Rather, it remains at a respectable level as long as parties with a class-based appeal maintain their traditional policy principles that attract particular voters, in this case championing decommodification as a social policy principle.

In the previous section, we discussed recent developments in the 2010 Riksdag election in Sweden that, at first glance, seem to disagree with the theoretical predictions for the Swedish case. These concern the SAP's electoral disaster and the emergence of a right-wing party, the Sweden Democrats. Given that the SAP was in opposition at that time and not responsible for policy making, I argued that the disaster must be explained by reasons other than the social policy-based arguments made in this study.

Finally, I want to address the obvious data limitations. The data sources used do not consist of all of the variables that would allow for a more consistent analysis, using the same data sources throughout the chapter. This poses a problem, as it prevents us from studying the direct electoral effects of social policy attitudes on party alignments. Nevertheless, the calculations of the party shares drawn from Oscarsson \& Holmberg's figures (2008: appendix A), which do rest on the election studies, revealed that the SAP mobilised a considerable share of core constituents over the 
period examined. Together with the patterns of voter migrations shown above, this indicates that an outright setback for the SAP among its core voter base has not occurred. The combined descriptive and statistical analysis revealed that the gains of the Left Party (and the Christian Democrats) were temporary, even though the proof was indirect. Further analysis with sophisticated items would give a more comprehensive picture.

Summing up, the Swedish case provided evidence that social democrats are able to retain a strong backing among their core constituency if they do not adopt a Third Way agenda and instead stick to more traditional social policies by maintaining the decommodification principle to a sufficient degree. In this case, core voters do not dealign from the party or even realign with other challengers on the margins. 


\section{Comparative Summary}

This chapter summarises the findings of the preceding chapters and puts them in a comparative setting. It reviews the empirical support for the theoretical framework and the party competition argument made in Chapter 2 and addresses the extent to which the developments in the four countries converge and diverge. Rival explanations and developments that seem to diverge from my framework are then discussed.

\subsection{General expectations and summary of findings}

The book's very general point of departure was that social democratic parties that have engaged in recommodifying welfare state reforms risk being punished by the electorate, on the grounds that social democrats have engaged in policies that contradict their traditional social policy stance and their core constituents' attitudes. Drawing on Esping-Andersen's work $(1985,1990)$, I argued that social democracy typically formed and aligned a core constituency consisting of manual workers and lower white-collar employees. These classes have few resources and marketable skills and thus demand income replacement in case of invalidity, old age, sickness and unemployment, which is understood as the decommodification of the wage earner. Moreover, they typically benefit from the redistribution of income, given their average below-median incomes. These classes favour generous and universal social security schemes as well as egalitarian policies, which matches the core principles of social democracy as such parties traditionally advocate decommodification and redistribution (Esping-Andersen 1985; Merkel et al. 2008; Huo 2009). As a result, these voters formed lasting alignments with social democratic parties in the post-war era and the Golden Age of the welfare state.

My claim was that these alignments can be upheld as long as social democrats do not break with the decommodification principle in social policy. I maintained that social democrats risk alienating their core constituents if 
they engage in recommodifying policies, as happened in a couple of countries where social democrats reformed the welfare state under Third Way agendas (Dingeldey 2007; Merkel et al. 2008; Huo 2009). The welfare state reforms tightened the eligibility criteria for social security schemes or cut benefits. I expected core constituents to punish social democratic parties in elections, because the latter had engaged in policy change that contradicted the attitudes and social policy preferences of the core constituency.

To test this claim, I chose the cases of Denmark, Germany, Sweden and the United Kingdom. In contrast to British, Danish and German social democracy, which modernised under Third Way agendas, the Swedish SAP adhered to a more traditional stance in the 199 os and did not break fundamentally with the decommodification principle. The British Labour Party, the Danish SD and the German SPD implemented path-breaking labour market reforms after they had adopted Third Way agendas. The reforms sharpened conditionality in social security, tightened eligibility criteria and entitlements, cut the replacement rates of unemployment benefits and thus introduced considerable recommodification of labour against social democracy's traditional notions in social policy. Therefore, I expected the Labour Party, the SD and the SPD to risk a lasting electoral setback among their core constituents.

The Swedish SAP did not suspend the decommodification principle substantially when it was in government between 1994 and 2006. It introduced some welfare state reforms and retrenchment early in this period, but these measures were part of the government's crisis management policy when Sweden was hit by an economic crisis during the 1990s rather than elements of a distinct Third Way agenda. Furthermore, some of the measures were temporary and were withdrawn once the crisis was over. The SAP did not enhance the conditionality of social security for the core workforce and the eligibility criteria were only tightened moderately compared to the reforms in Denmark, Germany or the United Kingdom. Other reforms concerned the fringes of the labour market rather than the core labour force. Furthermore, some elements of workfare always existed in the SAP's policy, whereas Labour, the SD and the SPD engaged in radical policy change under Third Way agendas. In sum, I expected the SAP to have avoided lasting dealignment of core voters in contrast to its British, Danish and German sister parties.

I developed a framework that conceptualises the expected logic and nature of the electoral punishment, to guide the book's empirical investigations. Even though I presumed that electoral setbacks among core voters occur for reform-minded Third Way social democrats, I argued that the 
extent of the punishment is contingent on the electoral system and party competition. The next sections review and compare the findings in view of these arguments.

The role of the electoral system for the electoral effects of the reforms

The first crucial aspect of the electoral effects framework was the role of the electoral system for the behaviour of social democratic core constituents after 'their' party had departed from its traditional stance on welfare under Third Way agendas. A FPTP system typically leaves voters with the non-voting option, as it effectively prevents the rise of competitor parties for social democratic parties. In contrast, a PR system does not prevent the emergence of new parties and thus does not prevent the rise of competitors for social democrats. This difference structures the electoral consequences of reforms: the most likely outcome in an FPTP system is abstention on the part of social democratic core voters, whereas realignment is much more likely under a PR system, as the alternatives are not marginalised through the electoral system. In the latter case, non-voting also remains an option. Table 8.1 presents the figures for the abstention of social democratic core voters, as well as non-core voters, for recent elections in the four countries.

Table 8.1 reveals that increasing abstention on the part of social democratic core voters as a consequence of the reforms is a particularly British phenomenon occurring in a country with an FPTP electoral system. New Labour began to implement New Deal labour market reforms after taking power in 1997. The reforms enhanced the conditionality in the unemployment insurance system and tightened eligibility criteria, as outlined in Chapter 5. The non-voter shares among Labour's core constituency doubled in the period between 1997 and 2010. This becomes especially visible if we compare the results from the first column of the table; that is, before the Third Way was realised with the turnout rates from the fourth column when Third Way social democrats had held office for two terms. Here the pattern for the UK is striking, since abstention among Labour's core constituency has tripled. By contrast, the degree of variation in the other countries is much smaller. The chapter on the UK shows that disaffected Labour core voters abstained after 1997. As they did not come back in the following election, there has been a much lower turnout among these voters under the aegis of New Labour.

In Germany, there was a modest increase in the number of non-voters among the SPD's traditional voter base when the red-green coalition was 
Table 8.1 Non-voter shares among social democratic core constituents and non-core constituents

\begin{tabular}{lrrrrr}
\hline \multicolumn{5}{c}{ Social democratic core constituency } \\
\hline UK & $14.7(1992)$ & $21.6(1997)$ & $35.1(2001)$ & $43.8(2005)$ & $37.6(2010)$ \\
Germany & $18.6(1994)$ & $12.0(1998)$ & $10.5(2002)$ & $12.5(2005)$ & $25.0(2009)$ \\
Denmark & $7.6(1990)$ & $9.5(1994)$ & $4.6(1998)$ & $6.5(2001)$ & $7.9(2005)$ \\
Sweden & $10.6(1991)$ & $11.0(1994)$ & $15.8(1998)$ & $15.6(2002)$ & $8.9(2006)$ \\
\hline UK & $10.2(1992)$ & $14.6(1997)$ & $25.7(2001)$ & $23.4(2005)$ & $18.4(2010)$ \\
Germany & $7.0(1994)$ & $4.4(1998)$ & $2.0(2002)$ & $7.3(2005)$ & $13.4(2009)$ \\
Denmark & $10.7(1990)$ & $3.6(1994)$ & $3.2(1998)$ & $2.3(2001)$ & $3.3(2005)$ \\
Sweden & $6.2(1991)$ & $5.4(1994)$ & $7.1(1998)$ & $7.2(2002)$ & $6.6(2006)$ \\
\hline
\end{tabular}

Source: Own calculations. Shaded cells indicate first-past-the post-electoral system.

in power between 1998 and 2005. Chapter 6 revealed that the SPD lost core voters through abstention in 2005 as consequence of the reforms, but this was not as pronounced as in the case of Labour in Britain, where the exit option was clearly the dominant electoral effect. However, in the 2009 federal election, turnout among SPD core constituents dropped sharply, which will be further addressed in the conclusion. In Denmark, there is no clear observable trend for the Nyrup period, only a slight increase for the elections 1998-2005, but abstention in 2005 remained at roughly the same level as in 1990. Moreover, the analysis in Chapter 7 did not yield any significant results for increased non-voting, due to disaffection with social policy. Denmark thus remains the case where the reforms did not produce any increased and class-based abstention. This fits with official data reporting stable turnouts during the period under review (www.folketinget.dk).

In Sweden, non-voting among the SAP's core constituents increased modestly after the party introduced measures to fight the crisis, but the figures never reached British or German levels, and turnout among these voters recovered with the 2006 election. Looking at the lower half of Table 8.1, we can observe that there is less variation in abstention among non-core constituents. In all four countries, non-core voters had a higher turnout than core voters, irrespective of the electoral system or whether reforms had been implemented by the ruling social democrats. In this group, the patterns are also less clear than those for the social democratic core constituency. For the UK, we notice the FPTP effect for these voters too, but the increase is much more moderate over the whole period. Simi- 
larly, abstention among non-core voters in Germany increases in 2009, but not as much as among the SPD's rank and file. The other two cases show no patterns if one regards the figures for the Danish 1990 election as an outlier. This brief comparison confirms the argument that it is precisely the social democratic core constituency that is concerned about and affected by the reforms, and then has to decide whether to continue supporting the social democrats.

In sum, the expected effect of the electoral system on the electoral outcome has been confirmed by the case studies as well as the brief comparison of turnout in this chapter. The British Labour Party faced increasing abstention by the party's core constituents under the country's FPTP system, whereas the social democratic parties in the three other countries did not lose their core voters primarily through abstention, as the countries have PR systems. This brings us to the second crucial aspect of the party system framework: the presence of particular competitor parties that may attract social democratic core voters.

The role of party competition for the electoral effects of the reforms

I argued that under PR systems, competitor parties have a much better chance of fostering a realignment of social democratic core voters and that, in line with the literature, left-wing parties should be the most dangerous competitors for reform-minded social democrats, as they also traditionally have pro-welfare programmes. Right-wing parties represent the second type of dangerous competitors due to their socio-cultural appeal to social democratic core voters. The four cases are classified in Figure 8.1, which shows the effective competitors the social democratic parties faced during the period under review.

Figure 8.1 Electoral system, party competition and effective competitors for reformminded social democrats, c. 1990-2009

\begin{tabular}{|llll|}
\hline \multirow{2}{*}{ Reforms } & FPTP & PR & \\
\hline No & Competitors marginalised & Left & Right \\
Yes & Non-existent & Sweden (only in 1998) & - \\
\hline
\end{tabular}

In contrast to Figure 3.1, this figure accounts for the credibility considerations concerning competitors. Qualifications apply when it comes to the 
matter of whether social democratic core voters will shift to a competitor as a consequence of the reforms. If the parties engaged in reforms on their own, or supported reforms as part of a formal or legislative coalition, they have dirty hands and are not seen as credible by disaffected social democratic core voters. This is why Denmark is now classified as having had no left challenger. Similarly, if a vote for a leftist party is wasted because the party is marginalised by the electoral system, there is no reason for a voter to shift.

Another type of party that may benefit from Third Way reforms is that of the mainstream party that has traditionally attracted a considerable share of social democratic core voters or has accommodated the preferences of these voters. Examples include welfare-minded Christian democratic parties such as the CDU, or a mainstream competitor to social democrats such as the Danish Liberals, which transformed the basis on which it appealed to voters when the Danish social democrats reformed the welfare state.

The case study chapters demonstrated that the predicted logic of electoral change could be confirmed by the empirical analysis to a large extent. The Labour Party did not experience a realignment of core constituents with a party on the margins. As mentioned above, the main electoral effect in the British case was increased abstention by Labour's core voters after the party changed its policy under New Labour. ${ }^{1}$ This is in line with the anticipated effect of an FPTP system, as this system was expected to prevent the emergence of serious competitors such as leftist pro-welfare and/or authoritarian right-wing parties. Nevertheless, some gains for the Liberal Democrats and minor parties did occur.

However, the Liberal Democrats have not won over enough of the social democratic core constituency in Britain to be able to speak of a realignment such as that seen in Germany, where a left competitor made considerable and lasting advances to the detriment of the social democrats. The Liberal Democrats did increase their vote share under New Labour in general, but this was not associated with a distinct realignment of Labour core voters. In terms of my framework, the Liberal Democrats turned out to be an ambiguous case. ${ }^{2}$

In Britain, other parties had been marginalised due to the first-pastthe-post electoral system and Labour was not in any real danger of losing large vote shares to opponents on the far left or far right. However, there are some indications that Labour's ideological repositioning and policy change have led to gains for parties on the margins. The far-right BNP has 
made continuous advances under the aegis of New Labour, typically in (former) Labour strongholds (Ford \& Goodwin 2010; Goodwin et al. 2010).

The two cases where social democrats reformed the welfare state under PR systems yielded two instances of successful realignments and one without a realignment to a dangerous competitor. Concerning leftist parties, my empirical analyses revealed a realignment of social democratic core voters with a leftist competitor in Germany, but not in Denmark, after the reforms. The Left Party in Germany was able to foster such a realignment after the SPD engaged in path-breaking welfare state reforms in the electoral period 2002-05 and later under the grand coalition. In contrast, no such development occurred in Denmark, where neither the SF nor the Red-Green Alliance attracted social democratic core voters. ${ }^{3}$ This requires some discussion of the preconditions for the success of leftist competitors to social democracy in light of the party competition arguments of this book.

Given the theoretical arguments on the role of leftist competitors for the reforms' electoral consequences, the Left Party's breakthrough in Germany reflected a pretty straightforward development. The party was founded in reaction to the SPD's policy change, in particular the Hartz reforms. Mobilising on anti-reform and pro-welfare from the very beginning, the Left Party presented itself as a credible alternative to the four established parties, at least for the reform-averse segments of the electorate. The Left Party and its predecessor the PDS had not been involved in legislation and were thus not responsible for policy making at the federal level, as the government had an overall majority. The social democrats in particular had been attacked for their policy changes under Schröder and the Left Party presented itself as the 'real' social democratic party, defending the welfare state.

The party was thus able to pursue a clear opposition policy, given its 'clean hands', and to attack the SPD on its own turf, the welfare state. Chapter 6 demonstrated that a negative attitude towards the SPD's reforms was a significant predictor of a realignment of social democratic core constituents with the Left Party. The Christian democrats did not benefit from the reforms, despite their traditional welfare image, since the party had its own reform agenda and had damaged its credibility beforehand. The realignment towards the Left Party is thus consistent with my arguments, as social democratic core voters shifted to a leftist pro-welfare party that had not damaged its credibility with previous political responsibility. The realignment was lasting; the SPD did not recover this voter segment and the Left Party even increased its share 
in the 2009 federal election. This differs from the Danish case, which also featured a leftist competitor, but one that could not foster a realignment of social democratic core voters, as demonstrated in Chapter 7 .

In terms of my theoretical framework on the importance of left-socialist challengers, the Danish SF was an established leftist and pro-welfare party that could be expected to attract social democratic core voters as a consequence of welfare state reform. Nevertheless, the socialists failed to accomplish a realignment of social democratic core supporters. My explanation is that the party had dirty hands before the third and most comprehensive reform package was launched by the social democratic government, because it was one of the parties that supported the SD minority government after 1994 . The party generally cooperated with the social democratic government between 1993 and 2001 (Spier \& Wirries 2007: 100, 104; Mortensen 2011: chap. 17). Consequently, Chapter 7 revealed that the SF did not make gains among social democratic core voters who opposed the welfare policy of the reform-minded social democratic government. The SF's shares among reform-averse social democratic core constituents did not differ from its shares among the more reform-minded, and voters did not turn to the socialists due to the reforms.

By contrast, the Danish case demonstrated the realignment of this voter segment with a right-wing competitor, the Danish People's Party. The party emerged in Denmark in 1995 after an internal split in the Progress Party, which had a market-liberal agenda. ${ }^{4}$ The Danish People's Party was not involved in the Nyrup government's welfare state reforms as the party was often not part of cross-party agreements (Forlig), which are typically used in Danish legislation processes if there is a minority government (Christiansen 2008). Unlike the SF, the party generally did not support the social democratic minority government. Like the Left Party in Germany, the party could perform a pure opposition and protest strategy, as its credibility had not been damaged beforehand. The analyses in Chapter 7 have so far shown that this party made its first gains among the social democratic core constituency in the 1998 election and was able to forge a lasting realignment of social democratic core voters in the 2001 election after the third and most encompassing round of labour market reforms. Many reform-averse social democratic core constituents shifted to the Danish People's Party and stuck to the party in the 2005 election.

Another development in the Danish case is an anomaly that cannot be 
fully explained by my framework: the Liberal Party's gains in the period between 1990 and 2005. In general, the Liberals made considerable gains among the social democratic voter base as the party started to appeal to a broader voter segment in the 1990 os. However, the party supported several of the social democrats' reforms and thus had dirty hands. Nevertheless, the analyses for the period between 1998 and 2001 show that the Liberals attracted social democratic core voters who were dissatisfied with the social democrats' approach to welfare.

Finally, the Swedish SAP's core voters did not realign with a competitor. The party lost core constituents to the Left Party in 1998 after having engaged in crisis management and cuts. However, in line with expectations, this was not a lasting realignment, as the SAP regained a considerable share of these votes from the Left Party in 2002. The Left Party's support among the social democratic core constituency peaked with the 1998 election, after which support dropped to normal levels again. The Christian Democratic Party, which also mobilised core voters from the SAP in the 1998 election, experienced similar temporary gains. The Swedish case thus demonstrates that the SAP could keep a considerable share of core constituents, as the party maintained the decommodification principle when it governed between 1994 and 2006. There were no patterns of lasting realignments to a challenger such as the Left Party, or dealignment of the SAP's electoral backbone.

The gains have elements of realignment, but this must be interpreted with some caution. The party's share among the social democratic voter base is not stable. It declined somewhat after the Liberals' victorious 2001 election, whereas the DF has kept these voters for at least one decade. It is striking that the Liberals won these votes despite having supported several of the social democratic welfare state reforms in the Folketing. The party's gains are puzzling in terms of my arguments, as is the nonincrease in non-voting in the Danish case. One reason could be that two parties - the DF and the Liberals - explicitly wooed the social democratic core constituency, and thus offered two alternatives to abstention. Moreover, a rather low threshold of two per cent provides voters with many alternatives at the ballot.

Summing up, the theoretical arguments on how social policy affects partisan alignments to social democratic parties and the party system argument for the electoral consequences of welfare state reforms are supported by the empirical analyses to a considerable extent. Social democratic parties that abandon their traditional stance on welfare and pursue recommodification alienate their core constituents and face punishment at 


\begin{tabular}{lll}
\hline & Hypothesised & Observed \\
\hline Sweden & $\begin{array}{l}\text { No dealignment as reforms were } \\
\text { moderate; temporary gains for Left Party } \\
\text { after 1998 }\end{array}$ & $\begin{array}{l}\text { Temporary gains for Left Party after } \\
\text { share in 1998; no lasting realignment }\end{array}$ \\
UK & $\begin{array}{l}\text { Dealignment of Labour core voters into } \\
\text { non-voter camp }\end{array}$ & $\begin{array}{l}\text { Dealignment of Labour core voters into } \\
\text { non-voter camp; (indirect) gains for } \\
\text { Liberal Democrats and minor parties }\end{array}$ \\
Germany & $\begin{array}{l}\text { Realignment of social democratic core } \\
\text { constituents towards Left Party }\end{array}$ & $\begin{array}{l}\text { Realignment of social democratic } \\
\text { core constituents towards Left Party; } \\
\text { abstention of social democratic core } \\
\text { voters (especially 2009) }\end{array}$ \\
& & $\begin{array}{l}\text { Realignment of social democratic core } \\
\text { Denmark }\end{array}$ \\
& Realignment of social democratic core \\
constituents with Danish People's Party & $\begin{array}{l}\text { constituents with Danish People's Party; } \\
\text { realignment with Liberals among social } \\
\text { democratic core constituency }\end{array}$ \\
\hline
\end{tabular}

the polls. The actual extent of the electoral backlash depends on the party system, that is, the presence or absence of particular competitor parties, which is also contingent on the electoral system. In the countries where Third Way social democrats faced credible competition from the wings, core voters realigned with those parties. However, this did not happen in the FPTP system due to the marginalisation of non-mainstream parties (see Table 8.2).

\subsection{Discussion of rival explanations}

The summary of the findings reveals first that the blame-avoidance argument found in the New Politics literature does not hold if social democrats reform the welfare state in ways that are contrary to the parties' traditional social policy image.

Paul Pierson's seminal New Politics of the Welfare State approach (1994, $1996,2001)$ states that the logic of welfare state reform diverges from the logic of welfare state expansion, as policy makers cannot claim credit for the former but only for the latter. This is because the welfare state has formed its own constituency and, consequently, policy makers interested in re-election refrain from introducing encompassing reforms. If policymakers nevertheless implement reforms, they apply various strategies of blame-avoidance to evade electoral punishment. 
The cases revealed that blame-avoidance strategies may work once, but they do not prevent a party from losing its core voters in the long term if the party pursues policies that run counter to its traditional stance on welfare. This is illustrated by the German 2002 election and the Danish 1998 election. In the campaign for the 2002 federal election, Chancellor Schröder used the flood in the eastern states and the impending war in Iraq to rescue his unpopular red-green coalition, and his government maintained its majority. Prior to that, Schröder's government had implemented the Riester pension reform, which introduced a partial capitalisation of old-age provisions in Germany that ran counter to the SPD's principles on pensions and social policy. However, Schröder's blame-avoidance measures did not prevent losses for the SPD and gains for the Left Party among the social democratic core constituency in the following elections. Likewise, Danish Prime Minister Nyrup Rasmussen survived the 1998 election by a tight margin after the first labour market reforms had been implemented, by promising not to reform the popular early retirement scheme. Afterwards, the social democrats continued to implement labour market reforms, including a reform of the early retirement scheme. In the 2001 election, the social democrats were severely punished and many social democratic core voters realigned with the Danish People's Party. Hence, blame-avoidance may allow a party to survive the (first) election after ideological change and/or unpopular reforms, but has not prevented the lasting farewell of social democratic core constituents. In this vein, Pierson's argument concerning the general electoral threat of welfare state retrenchment is correct, as the analyses reveal considerable electoral punishment. On the other hand, blame-avoidance does not work if parties depart from their traditional stance on welfare and are punished. This punishment is not only an electoral defeat, but goes hand in hand with a dealignment of core constituents, even if blame-avoidance measures have been taken.

The findings reveal that reforming the welfare state is electorally hazardous, particularly for parties such as social democratic parties, which traditionally tie their core constituencies to specific welfare policies. This is a more fine-grained specification of the arguments made by Pierson, Vis and Giger, which point to the general electoral risks if incumbents engage in retrenchment (Pierson 1994, 1996; Vis 2009, 2010; Giger 2011; Giger \& Nelson 2011). With respect to Pierson and the New Politics School, blame-avoidance is not a lasting strategy to evade electoral setback for reform-minded social democrats. Parties matter in terms of whether retrenchment is electorally costly or not. Parties that traditionally advocate 
risk-hedging social policies are exposed to severe losses if they violate this principle by cutting back the welfare state. Parties with no reputation on welfare may find it easier to retrench the welfare state without taking the electoral blame, since in doing so, they are not acting against their own social policy legacy (cf. Giger \& Nelson 2011). This may explain the mixed results in Giger's research, with its focus on vote choice for incumbents after retrenchment (Armingeon \& Giger 2008; Giger 2011; Giger \& Nelson 2011). Giger's recently published book maintains that the electoral risks attributed to welfare state reforms are probably overstated, as many incumbent governments survive elections despite having engaged in retrenchment. Moreover, the electoral blame varies substantially between electoral contexts. In light of these claims, I briefly contrast the results from Giger's book with the findings of this study.

Given the two different research designs, the comparison remains necessarily crude. As mentioned, Giger's main claim is that the electoral risks of retrenchment are probably overrated, as only a few incumbent governments have been punished after retrenchment (see also Giger \& Nelson 2011). Considering my findings, Giger's claim may be too general, but this could be caused by the research design.

As Giger's analysis only chooses for or against the incumbent government (respectively the main governmental party) as the dependent variable, there is no distinction between parties or party families. Therefore, completely different types of parties are treated as being within the same category, such as reform-minded market liberals and pro-welfare socialists, when in office. But there are strong reasons to expect the electoral effects to differ by party family if governments engage in cutbacks. My analyses demonstrate the electoral effects of reforms implemented under Third Way agendas by ruling social democrats. These effects cannot be identified by Giger's research design. A related weakness is the prior exclusion of non-voters from the analysis (cf. Giger 2011: 68), which may have weakened or even added bias to some of the effects. As my book shows, this is especially true for countries with majoritarian electoral systems, since reform-averse voters often have no alternative and thus do not necessarily shift to the opposition, but stay at home. This segment of voters and their behaviour in the wake of welfare state reforms are unfortunately not captured by Giger's analysis.

Giger also used only one election per country (except for Portugal), which makes it difficult to trace back the long-term effects of retrenchment found in her thesis. Also, the elections are not selected based on whether considerable retrenchment took place, so many elections where 
reforms were likely to have influenced the results are omitted, for instance the British general election in 2001, the German federal election in 2005, the Swedish 1998 Riksdag election and the elections in New Zealand during the period of radical retrenchment in the 1980 os and 1990 os.

The results of my study thus supplement Giger's contribution with a more nuanced account of the actual electoral consequences of reforms. After they depart from their conventional social policies, parties with a traditional programmatic commitment to a generous welfare state risk losing parts of their core constituency to other parties or to abstention. This was the case for Third Way social democrats that suspended decommodification to a substantial degree. The actual electoral effects of such policy changes can be quite substantial, as this book has shown. It has proved fruitful to conceptualise policy changes from both a qualitative and quantitative perspective to obtain a more comprehensive picture of the actual change.

An important implication is that we have to take into account which type of party implements which policy to formulate our expectations about the electoral consequences of welfare state reforms. Simple budget consolidation measures implemented under bourgeois governments may ultimately be less costly than recommodification implemented by social democrats, as the latter party family draws on a core constituency that demands the very opposite.

The same can be argued when it comes to another rival explanation, one that originates from the New Politics School. Ross (2000) maintains that social democrats could use their ownership of social policy issues to avoid electoral blame when they chose to reform the welfare state. This 'Nixon-goes-to-China logic' did not work in the cases where social democrats reformed the welfare state.

The results show that this explanation does not apply to the British, Danish and German cases. The three social democratic parties modernised under Third Way agendas and while they might have won the first Third Way election with their traditional welfare image, this reputation was subsequently damaged in all three cases. Under its novel New Labour label, British social democracy lost the image of representing the interests of the working class and the unemployed to a considerable degree. Core voters no longer attributed this image to their traditional political choice after the party engaged in the New Deal reforms, and stayed at home. In Denmark, the centre-right parties caught up with or even took over the social democrats' ownership of welfare issues during the period between 1994 and 2001, when the SD changed its programme and reformed the 
welfare state (Goul Andersen 2003a; Blomqvist \& Green-Pedersen 2004). The Danish People's Party successfully presented itself as the representative of ordinary wage earners and claimed that the social democrats had lost this function. In Germany, the Left Party attacked the social democrats for having departed from their social democratic profile under Schröder and the Agenda 2010 reforms. So did many social democratic voters (e.g. Debus 2008). In turn, the Left Party increased its share of voters, who saw this party as owning the welfare issue.

In view of this evidence, Ross' claim about issue ownership is rather static and does not account for loss of the welfare issue as a result of reforms breaking with social democracy's traditional social policy image. If this happens, other parties may win the issue and an electoral setback occurs, contrary to the Nixon-goes-to-China logic.

Therefore, the two rival explanations do not apply to a comprehensive explanation of the developments in Denmark, Germany and the United Kingdom. Blame-avoidance cannot prevent long-lasting dealignments of partisans after retrenchment. This perspective is rather myopic and while it may help explain why one election was successful, it fails to account for subsequent losses. It may be easier for social democrats to implement welfare state reforms given their ownership of the welfare issue, as elaborated by Ross (2000) and as shown for the cases of Denmark and the Netherlands in Green-Pedersen's analysis (2002a). Nevertheless, the parties lose the issue by reforming the welfare state, and other parties may have a chance to win the issue among a significant share of the electorate and thus mobilise previous social democratic core supporters. In this vein, recommodifying reforms implemented by social democrats cause electoral setbacks that cannot be explained or prevented by blame-avoidance or ownership of welfare issues.

Furthermore, the results must be placed in the context of another rival explanation, the postulated decline of class voting as a trend in modern societies. As discussed in the theoretical chapter, the decline of class voting literature offers various explanations concerning the weakening effect of voters' social class on vote choice and party alignment. In particular, it has been argued that social democratic parties need to modernise their appeal to middle-class constituencies and tone down their working-class appeal, as this latter constituency is shrinking. This argument typically concerns the period before the Third Way; that is, between the 1970s and 1990 s. It can be argued that my findings simply reflect a continuation of the trend towards the declining importance of class for the vote choice especially the role of class for alignment towards social democratic parties. 
However, the empirical analyses demonstrated that the reforms did affect whether social democrats would lose considerable support among their core constituencies, mainly through dealignment (United Kingdom) or realignment (Denmark, Germany). In Sweden, the deviant case, the SAP's share among its rank and file fluctuated rather than declined, as the party did not adopt a Third Way agenda. The reforms may have triggered a weakening of support for social democrats among traditional core voters. Of course, this development can be interpreted as a further decline in class voting, but in contrast to macro-level explanations, the study demonstrated that there is no secular trend towards declining support for social democrats among their traditional core voters. Rather, policy and policy change mattered for the logic of electoral change. ${ }^{5}$ Accordingly, the Third Way may be seen as a response to the decline of class voting in a first step (e.g. Giddens 1998), but also as a catalyst of this (postulated) trend, as the diverging development in Sweden showed.

In a similar vein, the declining support for social democracy could be regarded as the cost of ruling. One simple argument may be that the parties studied in this book have simply suffered average losses after ruling for long periods. All social democratic parties contested at least three elections after having gained office in the 1990 os $^{6}$ Admittedly, the costs of ruling may account for some of the decline, but not for the departure of the social democratic core constituency. The average costs of ruling for mainstream parties are likely to appear among swing voters who do not belong to the core constituency. According to Esping-Andersen's theory, the social democratic core constituency was traditionally the electoral backbone and was tied to the party irrespective of the political situation. The results demonstrated that the losses occurred in the core electorate after reforms were implemented, which strongly suggests that the results cannot be solely explained by the average costs of ruling, but also by the policy change introduced by Third Way social democrats. Otherwise, the Swedish pattern of electoral change could be expected to be more similar to those found in the other countries, as the SAP - liked Labour and the SPD - governed for three consecutive terms. In view of the fact that by 1995, at least one out of four voters in Western Europe belonged to occupational groups conceptualised as social democracy's core constituency (see Table. 2.3), the losses for Third Way social democrats were of a nonnegligible nature, but not a simple result of declining class voting.

Another rival explanation from the literature on the new right is that these parties tend to win by mobilising on socio-cultural issues, especially immigration, as their positions on these issues match those of so- 
cial democratic core voters (Kitschelt 2001b; Scheuregger \& Spier 2007; Houtman et al. 2008; Kriesi et al. 2008). This objection concerns the Danish case in particular. One might argue that the DF's gains were the result of a specific aspect of social democracy's transformation under the Third Way agenda, which did not concern welfare policy as such, but rather socio-cultural issues. Giddens has proposed 'cosmopolitan pluralism' as a distinct Third Way value (Giddens 1998: 66; cf. also Kriesi et al. 2008: 16). Kitschelt (2001b: 440), using the examples of New Labour and the Democrats under Clinton, has argued that social democracy has increasingly endorsed libertarian positions to attract the new middle class and highlyskilled employees. The price was sacrificing those parts of the core constituency that do not hold libertarian attitudes. This generated increasing voter potential for authoritarian right-wing parties. From this perspective, the Third Way also has alienating effects on social democracy's core constituency, which endorses other values on the socio-cultural dimension than 'cosmopolitan pluralism'.

On that score, the emergence of the immigration issue over the last two decades is often seen as the driving force for electoral change in Denmark (cf. the volumes of Andersen et al. 1999; Goul Andersen \& Borre 2003; Goul Andersen et al. 2007; also Qvortrup 2002). Not surprisingly, and given Giddens' and Kitschelt's arguments, this concerns the rise of the Danish People's Party with its sceptical views on immigration. Similarly, the SF's failure to attract social democratic core voters should be the consequence of the presence of the immigration issue on the political agenda, as the party alienated possible new voters with its libertarian stance.

However, the Danish case reveals that the Danish People's Party's success depended considerably on the voters' attitudes towards the Nyrup government's social policy. Social democratic core constituents who opposed the Nyrup government's welfare policy and saw immigration as a threat were more likely to switch to the DF. Attitudes towards immigration as such do not account for the realignment. The DF could only capitalise strongly on the immigration issue once the welfare link between the SD and its core voter had been broken as a consequence of the labour market reforms. Moreover, Goul Andersen (2003b) has claimed that the 2001 election was also a welfare election, and not only an election where the agenda was dominated by immigration. Giger (2011: 129) has shown that social policy was the major campaign issue in the 2001 election for the Folketing.

Similarly, one may object that it has been the left-libertarian image of the Socialist People's Party that has accounted for the party's failure to 
gain from the reforms. The results for the party did not differ on the opinion about the reforms, indicating that the party had no chance to mobilise new supporters despite its welfare image. One reasonable explanation is that the party had dirty hands after supporting the social democratic government. It is true that the party's performance among voters with a sceptical stance on immigration was weaker, but this was not contingent on these voters' attitudes on welfare policy. The party clearly did not benefit from its position on immigration, but it had already damaged its credibility by supporting the social democratic government that introduced the labour market reform. Otherwise, the party would have gained votes, at least among voters who did not regard immigration as a threat, but who were displeased with welfare. The rival explanation that the cultural dimension is the driving force of gains of the authoritarian right and nongains for the left becomes more supplemental in light of my findings. The reforms triggered the electoral change in the Danish case, whereas the immigration issue magnified the effects, to the advantage of the Danish People's Party and the disadvantage of the Socialist People's Party. 



\section{Discussion}

This book has investigated the electoral consequences faced by social democrats after having transformed themselves under Third Way agendas and reformed the welfare state in ways that are contrary to traditional social democratic principles such as decommodification, solidarity and egalitarianism (Esping-Andersen 1985, 1990). Esping-Andersen conceptualised the alignment to social democratic parties as a match between their supply of social policy and the demands of the working class and lower white-collar employees. Thus, the decommodification of the wage earner has traditionally been a priority for social democracy, as these policies bound social democracy to its core constituency.

Applying a partisan politics perspective, I argued that by adopting the Third Way agenda, social democrats risk alienating their core constituency, as this implies a moderation of social democracy's stance on social policy. In particular, the welfare state reforms implemented under the Third Way broke with the decommodification principle, since eligibility and entitlements were curtailed, the universality and generosity of social security reduced and benefits cut. Hence, the guiding focus has been the core constituency's potential dealignment from social democracy. Integrating Esping-Andersen's theory into arguments from the New Politics of the Welfare State literature, I established a framework conceptualising the electoral consequences of recommodification for social democracy.

First-past-the-post electoral systems produce a dealignment of social democratic core voters into the non-voter camp, as this electoral system effectively prevents the emergence of serious competitor parties for Third Way social democrats. In contrast, PR systems not only produce dealignments, they are also expected to produce realignments of social democratic core voters, as dangerous challengers to social democracy are present or can easily emerge. Two types of parties have been identified as the most dangerous competitors for Third Way social democracy. First, left-socialist parties can attract social democratic core voters due to their pro-welfare stance in times when social democrats have damaged 
their welfare reputation. Second, authoritarian right-wing parties have a chance to woo social democratic core voters if the welfare link is broken, because they match voters' preferences on socio-cultural issues. An important qualification in this respect is that credibility considerations affect whether social democratic core voters will shift to a competitor. The claim is that realignments do not occur automatically once voters become dissatisfied with the social democrats. If challengers alienate possible voters by adopting a reform agenda of their own or a distinctly libertarian domestic policy, then they destroy their prospects of winning voters from the social democrats. These propositions were examined using the cases of Denmark, Germany, Sweden and the United Kingdom.

The Swedish case supported the claim that social democrats are able to maintain stable support from the traditional core constituency if they stick to traditional social democratic principles in social policy. The British case demonstrated that Third Way social democrats lose core voters to abstention if they reform the welfare state under a majoritarian electoral system. The case of Germany revealed that a credible left-socialist challenger could forge a realignment of social democratic core voters as a consequence of Third Way reforms. The Danish case demonstrated that left competitors could not attract social democratic core voters if they had previously lost credibility. Moreover, it supported the claim that rightwing authoritarian parties could foster a realignment of social democratic core voters as an effect of Third Way reforms. The results raise questions about the political implications of the Third Way and social democracy's future electoral fortunes, questions that will be discussed after considering the applicability of the book's arguments to further cases.

\subsection{Applicability of arguments to other countries}

Given that the theoretical framework of the electoral consequences of welfare state reforms featured four countries with considerable variation in party systems and party behaviour, it should be possible to apply the arguments to other countries where social democratic parties have reformed the welfare state.

The arguments about electoral systems and which types of parties are dangerous challengers also apply to other countries. In New Zealand, social democrats reformed the welfare state under an FPTP system in an example of radical welfare state retrenchment (Starke 2008). Both major parties engaged in far-reaching reforms of social security as well as the economy in 
general. The Labour Party (1984-90) reformed and retrenched various social security schemes and implemented tax reforms contradicting the traditional social democratic ideal of egalitarianism. Between 1984 and 1990, turnout in New Zealand declined by 8.5 per cent, a development that resembles the situation in the UK. Labour lost power, but the National Party continued the welfare state reforms, which led to the rise of new contenders, in particular a leftist party called 'NewLabour' that is the opposite of the British equivalent. ${ }^{1}$ The party won 5.1 per cent of the votes and one seat under the FPTP system in the 1990 election. At the end of the reform period and a successful referendum to change to a mixed member proportionality system (MMP), New Zealand saw the establishment of left- and right-wing populist parties as new competitors to New Zealand Labour. This reflects the patterns found in the UK, Denmark and Germany. ${ }^{2}$

In the Netherlands, the Labour Party (PvdA) began to modernise its programme and ideological stance in the 1980 os after a long period in opposition, despite good election results. The programmatic change first became visible in a coalition with the Christian Democrats (1989-94), and the party was among the first to develop a distinct Third Way agenda (Green-Pedersen et al. 2001). In this period, the party was involved in a highly unpopular reform of the very generous early retirement scheme. This was followed by significant losses for both major welfare parties in the 1994 election, where two retiree parties gained parliamentary representation. Nevertheless, the PvdA remained in office after forming a coalition with the right-wing liberals (VVD) and the social liberals (D66). This 'purple' coalition continued to reform the Dutch welfare state, making the labour market more flexible, increasing the use of active labour market policies and tightening eligibility criteria for social security schemes in the period between 1994 and 2002 (Vis et al. 2008). The social democrats went from having about one-third of the popular vote to less than onesixth in the 2002 election. The same period saw the rise of the otherwise marginalised Socialist Party (SP) to 6 per cent of the votes, gains for the pro-welfare Christian Democrats and the landslide victory of Pim Fortuyn's list. After the social democrats formed another reform coalition with the CDA, the SP peaked in 2006 with 16.6 per cent of the vote. The rise of the socialists is especially reminiscent of the developments in Germany, where a populist left-socialist party gained momentum after the social democratic party engaged in welfare state reforms as a consequence of an ideological realignment towards the centre. Since 1998, the PvdA has never reached 30 per cent or more of the votes after the party revised its programme and engaged in a reform of the Dutch welfare state. 
The case of the Norwegian Labour Party (Det Norske Arbeiderparti, DNA) matches the case of the Swedish SAP to some degree. The party modernised moderately during the 1990 s with a new discourse called 'work line' (Arbeidslinje) in response to growing unemployment (Dahl \& Drøpping 2001; Huo 2009: 7of). The reforms emphasised ALMPS and limited reforms of eligibility criteria and entitlement periods, but they were neither a fundamental break with the DNA's traditional social policy positions nor did they fundamentally recalibrate or retrench the Norwegian welfare state (e.g. Dahl \& Drøpping 2001; Huo 2009: 211ff). ${ }^{3}$ The Labour Party's vote share during this period fluctuated around 35 per cent between 1989 and 2009, with the exception of 2001, when the party only received 24.3 per cent after a brief stint as an ineffective minority government. The Left Socialist Party did not make lasting gains in the elections during this period. Hence, the case of the DNA resembles the pattern found for its Swedish sister party, as the reforms were moderate and the party did not suffer a lasting punishment, remaining the strongest party throughout the period.

\subsection{Contribution to existing literature and political implications}

My evidence shows that the literature drawing on party politics and party competition as explanations for reforms can be rewritten into a framework of the electoral consequences of those reforms. Determinants for the likelihood of welfare state reforms, such as the electoral system, the nature of party competition, and in particular the presence of left-socialist and authoritarian right blackmail parties, also structure the electoral consequences once the reforms have been implemented.

One implication is that majoritarian electoral systems not only determine the likelihood of reforms, as suggested by some authors (Kitschelt 2001a; Starke 2008), but also structure the electoral aftermath of the reforms. A majoritarian system such as the British FPTP electoral rule has been said to increase the propensity of reforms, as the party system does not include any serious veto players that can attack social democrats when they go for welfare state reform. The same logic applies after the reforms, as reform-averse voters lack an effective and credible alternative to abstention. It has been argued that PR systems hamper welfare state recalibration, especially if veto players such as left-socialist parties, Christian democrats or other kinds of blackmail parties exist. As these parties constitute a serious electoral threat to reform-minded parties, 
policy makers seeking re-election find it more difficult to implement reforms. This book reveals that the presence of such parties structures not only the path towards reforms, but also their electoral consequences in principle. PR systems with or without very low thresholds are likely to produce more electoral turmoil and lasting realignments as a consequence of unpopular reforms than majoritarian systems that keep blackmail and protest parties out.

A further implication is that those parties must be credible: they do not attract social democratic core voters simply by being there, as the literature often assumes. I demonstrate that credibility considerations do play a role in the electoral prospects of challengers. The two parties that 'came in from the cold' as non-established parties, the Left Party in Germany and the Danish People's Party, forged realignments, whereas the socialists in Denmark failed because they had dirty hands. In Sweden, the Left Party was unable to retain the votes gained in 1998 after the economic crisis, probably because it had acted as a support party for the social democratic government, which it had previously criticised for its crisis management. Similarly, the German CDU/CSU failed to capitalise on its welfare image after the SPD engaged in path-breaking reforms, since the party had its own reform agenda. In other words, blackmail parties or veto players identified by the new politics literature (Kitschelt 2001a) do not automatically benefit once reforms are implemented by a competitor, but are judged on their previous strategies. This implies that policymakers may implement reforms against the odds and avoid serious punishment if veto players (e.g. left-socialist or Christian Democratic parties) have dirty hands. Such situations may ease electoral dilemmas for reform-minded actors. The party and party competition literature should consider the credibility of suspected serious challengers to reform-minded mainstream parties.

This book contributes to the ongoing debate on the importance of class voting in Western democracies. As a point of departure, the Third Way was claimed to be a reaction to the suspected decline of class voting, namely the declining importance of working class votes for the electoral prospects of social democracy. My results show that in instances where social democrats adapted a Third Way agenda, this was a catalyst for declining support for social democracy on the part of the manual classes. In this respect, Kitschelt (1994) claimed that the old social democratic working class constituency would become too small to play a significant role in social democratic parties' future electoral considerations. This is why social democrats have to incorporate new middle class constituencies in their electoral programmes and tone down their working-class image. In 
a recent comment, Keman (2011) stated that the Third Way increased the office-seeking capability of social democracy, but its electoral position did not improve because it moved towards the political centre. Moving to the centre is regarded as an adaption to changing party systems and party competition to secure social democracy's potential to preserve government participation. Keman maintained that, at least in terms of officeseeking, the Third Way had been relatively successful.

However, my findings indicate that relying on these strategies can sometimes be dangerous, as the loss of this part of the electorate may dispossess social democrats of the ability to form majorities. Support from the core constituency may have dropped to the point where it is difficult to achieve parliamentary majorities, as seen in the cases of Denmark and Germany. In Denmark, the Danish People's Party took over a considerable part of social democracy's working class constituency after 1995. The votes were not used for a centre-left majority, but the Danish People's Party had supported a bourgeois minority government for more than a decade. During this decade, the SD had no chance to return to government, as the votes lost to the DF were a lasting loss for the bloc of leftist parties. Even the 2011 Folketing Election revealed a further small loss for the SD, and at the time of writing the party has never gained more than 25.8 per cent after 2001, and only the strong social liberals allowed the SD to replace the centre-right government supported by the Danish People's Party. In Germany, the votes that the SPD lost to the Left Party cannot be used to form a social democratic majority coalition (nor a centre-right coalition as in Denmark). The Left Party is still fundamentally an opposition party, and not credible or responsible enough to be included in any coalition at the federal level, which is to the disadvantage of the social democrats. Another aspect is that the low turnout of social democratic core constituents in the 2009 federal election allowed the bourgeois parties to form a majority coalition with fewer votes than the CDU/CSU and FDP gained together in 2005, but without obtaining a parliamentary majority. ${ }^{4}$ This is one striking effect of the lower turnout of former SPD core constituents.

Similar effects have been shown by Karreth et al's recent study (2012) on the electoral effects of social democracy's move to centrist positions under the Third Way. While successful at the first few elections, the repositioning eventually led to electoral slack and a weaker political position on the part of social democratic parties. Voters positioned on the centre-left or the left abandoned social democracy, which in turn could not maintain support among centrist voters. Further effects found by Karreth et al. (ibid.) have been the strengthening of left challengers and increas- 
ing abstention among leftist and former social democratic voters. These results resemble the findings in this book from a left-right perspective and lead to similar conclusions, namely that European social democracy lost former strongholds under the Third Way, while failing to attract new centrist (middle-class) voters in the long run.

Thus Third Way reforms may have shifted the balance of power in a couple of countries as social democratic parties lost a crucial segment of their electorate, and it is somewhat doubtful whether they could fully compensate for this by winning new core voters, as suggested by Kitschelt (1994, 1999), Giddens (1998) or Keman (2011). I will discuss this in more detail below.

Having analysed the breakthrough of the Danish People's Party, we learned that the Third Way could present a favourable opportunity structure for parties of the new right. As social democrats have abandoned the old positions in social policy that bound them to a working class constituency, authoritarian right-wing parties may now exploit this by appealing to these voters. This is especially effective if the parties' stance on socio-cultural issues, such as immigration or law and order, is supplemented by social protectionist appeals on welfare issues. Authoritarian right-wing parties can be regarded as post-industrial labour parties, in line with Kitschelt's propositions (2001b). This is reflected by the findings from the Danish case and recent developments in several other countries, where such parties have tried to combine a social protectionist stance on the socio-economic dimension with authoritarian appeals on the sociocultural dimension.

A related development is the emergence of a new social populist Left in response to the transformation of social democracy in some countries and Third Way welfare state reforms (March \& Mudde 2005). Die Linke's breakthrough is not only a German phenomenon; a similar development occurred in the Netherlands, where the Socialist Party gained nationwide significance after being completely marginalised in its first electoral appearances during the 1980 os and early 1990s. After the period examined in this book, the Socialist People's Party in Denmark seems to have developed in a similar direction. Having failed to gain votes in the elections from 1990 to 2005 , the party abandoned libertarian positions in domestic policy to some extent and used a tougher rhetoric on those issues. This was combined with an expansionary and somewhat populist stance on welfare, which allowed the socialists to gain 13 per cent in the 2007 election and capture a lot of working-class votes, as a recent poll has shown (Redder 2010). However, the party damaged its credibility again after the 
2011 election, when the party joined the social democrats and the socialliberals to form a government. The SF has campaigned on withdrawing the early retirement reforms of the previous centre-right government, but has now been forced to implement those reforms as a governmental party. This produced bad opinion polls after the 2011 election and is another tentative corroboration of the credibility argument on left-wing challengers made in this book.

Finally, Kriesi and collaborators' excellent book seems to apply beyond parties of the new right (Kriesi et al. 2008). Intensifying globalisation and welfare state recalibration may benefit not only authoritarian right-wing parties in terms of political mobilisation of the 'losers of globalisation and modernisation', but also a new social populist Left. These parties may attract such voter segments with a distinct social protectionist agenda, promising higher social benefits and an anti-establishment attitude. Such developments have already been observed by Kriesi et al. (2008: 340) and should be addressed in future research, to which I now turn.

\subsection{Implications for future research on social democracy}

In line with the electoral dilemma that preceded the Third Way, future research should examine what kinds of electoral and strategic dilemmas are faced by today's social democracy. This will enhance our understanding of social democracy's political future. New Labour insider and spin doctor Peter Mandelson recently described the strategic considerations of the Labour Party before the 2010 general election (Mandelson 2010: chap. 12). As the party faced both the Conservatives and the relatively strong Liberal Democrats as serious opponents, New Labour's campaign team had to choose between a riskier appeal to the middle classes, which could keep the party in office for one more term, or appealing to core voters, securing its traditional supporters to outperform the Liberal Democrats at least. This implies that the strategic tradeoff is still manifest for the electoral considerations of social democratic parties, even though most Third Way agendas have been abandoned in principle.

Furthermore, I claim that social democracy's future strategic trade-off could not only be a dilemma, but increasingly a trilemma between appealing to the traditional core constituency, appealing to new middle-class constituencies, and appealing to various outsider groups. Beginning with the latter, economic and societal changes have, at least in some countries, 
produced various groups of labour market outsiders and even a new postindustrial underclass as part of the electorate. This segment lacks regular employment and often lacks regular employment records, unlike the traditional social democratic core constituency (Huo 2009: 321; Lindvall \& Rueda 2012). Moreover, these people have often drawn social security benefits, in particular social assistance and housing benefits, for long periods or even their whole lives. In Max Weber's words (1920), they constitute 'Versorgungsklassen' (literally classes of public provision) and rely on the welfare state not only if they temporarily drop out of the market, for instance due to unemployment, but also as their main and permanent source of income. This problem was one motivation for some social democratic parties to adopt Third Way policies, but it remains urgent in many Western countries. For instance, the German SPD recently tried to strengthen its appeal to this voter segment by advocating higher benefits for the long-term unemployed and expansion of benefits for children from poor households.

These groups have different political preferences and demands from working-class or middle-class voters, which creates a political conflict between new and old social risk clienteles (Rueda 2005, 2006, 2007; Armingeon 2006; Kitschelt \& Rehm 2006; cf. also further contributions in Armingeon \& Bonoli 2006). Armingeon (2006: 118f) states that these trade-offs concern class-based social democratic parties in particular. Similarly, Rueda (2005, 2006, 2007) has proposed that labour market insiders and outsiders do not share political attitudes, especially on labour market and social policies. Social democrats have often been biased towards insiders and have neglected the political demands of outsider groups (cf. the recent analysis of this claim by Lindvall \& Rueda 2012). If social democracy focuses more on socially weak outsider groups, as maintained by Huo, electoral considerations may increasingly become a trilemma, as all three groups - the old core constituency, the middle class, and the outsiders (or the new underclass) - have distinct preferences and attitudes that are difficult to unite under a coherent electoral programme. Lindvall and Rueda's analysis (2012) indicates that changing priorities in favour of outsider protection brings electoral costs for social democratic parties.

An important aspect of this is the challenge from a new social populist left. We have established that the Third Way also accounted for the emergence of this type of party, and future research agendas should conceptualise this party family in a more elaborate manner and analyse its electoral fortunes. It is likely that social populist left parties affect the 
political landscape around the insider-outsider divide and hence the strategic considerations of social democracy. These parties may appeal to outsiders by promising higher social security benefits and by advocating tightly regulated labour markets for precarious forms of employment. This has been the recent strategy of the Left Party in Germany, which intensified the SPD's strategic dilemmas to incorporate both groups in its electoral programme. This calls for more research on the new populist left to enhance our knowledge on recent dynamics in electoral change in several countries.

The topics mentioned are strongly related to the discussion on whether social democratic parties have actually won new voter groups and formed new electoral coalitions by modernising their ideology, reforming the welfare state and appealing to highly skilled constituencies, as proposed by Kitschelt (1994, 2001b), Häusermann (2006, 2010) or Busemeyer (2009). Silja Häusermann (2006, 2010) argues that post-industrial pension reforms could be implemented as cross-cutting social divisions have allowed policymakers to engage in coalition-building. This has led to cross-class reform coalitions across the traditional capital-labour cleavage. As veto players and opponents have been incorporated in the public debate and legislative process, new actor coalitions have made it possible to implement pension reforms that otherwise would have failed. Another variant of the argument goes that social democrats have increased their focus on education to attract voter segments that prefer to see an expansion of the educational system (Busemeyer 2009). In some contexts, this strategy may generate new electoral alliances with the well-educated offspring of social democracy's old core constituency.

It has been argued that centre-left parties such as social democrats forged new societal alliances with highly skilled libertarian segments and various groups of labour market outsiders, who may form a new core constituency after levels of support from the working class have dropped (cf. Kitschelt 1994 for similar propositions). There are reasons to be sceptical about the proposition that social democrats have really attracted a considerable number of new voters who will form a lasting core constituency as a consequence of the policy shift. Even though this study has examined another type of reform, my results indicate that social democracy's electoral strength did not seriously improve, as the votes lost among the core constituency were not offset by new voters from other constituencies due to the reforms. The Third Way may have increased social democracy's strategic flexibility, especially in terms of broadening the coalition options, as stated by Keman (2011). This is one 
likely reason why cross-class coalitions and cross-party coalitions in welfare state recalibration were possible, as demonstrated by Häusermann $(2006,2010)$. On the other hand, it is doubtful whether these developments went in line with new and stable electoral alliances between social democracy and the new target voter groups (see Karreth et al. 2012 for a similar argument).

Future research has to investigate whether recent welfare state recalibration has materialised in new and stable electoral alignments or merely ephemeral reform coalitions in parliaments. The findings here point to the latter direction as the gains, if they were even made, among the admittedly roughly specified non-core constituency, were not substantial. One reason could be that social democracy's traditional working-class constituency was indeed tied by the party's programmatic commitment in the heyday of welfare capitalism, whereas the new voter groups have more ambiguous attitudes on socio-economic issues, as Häusermann suspects (2010: 215f).

It is more difficult to forge a lasting alignment with social groups that lack coherent and consistent social policy preferences compared to the match between old social democracy's political positions and the working class constituency's social policy preferences. This problem needs to be elaborated by using recently developed class schemes to account for labour market stratification in post-industrial societies (Müller 1999; Kitschelt \& Rehm 2005; Güveli 2006; Oesch 2006). The schemes distinguish occupational groups that authors such as Kitschelt (1994) and Häusermann $(2006,2010)$ have identified as target constituencies for social democracy. Comparative and longitudinal studies should reveal whether and under which circumstances social democratic parties can successfully forge new class coalitions with the highly skilled and libertarian segments of the electorate.

The cases studies in this book suggest that only New Labour succeeded in gaining a foothold among new groups of the electorate. Together with the current electoral bias of the British electoral landscape, the party survived the 2001 and 2005 elections with comfortable majorities, despite the dealignment of parts of the core constituency. Labour might have won the new voter groups that Kitschelt and others have specified as new target groups for the same reason that it only suffered a dealignment, but no realignment, of its core voters. The electoral system prevents competition from parties that typically attract these voters. Apart from the mainstream Liberal Democrats, New Labour did not face a distinctly left libertarian, green or radical liberal party in Westminster elections. This may have 
compensated for the losses among Labour's traditional core electorate and secured the majorities in 2001 and 2005, in spite of the large drop in turnout caused by the party's ideological transformation. Labour has thus suffered fewer political costs as a consequence of the modernisation under the Third Way compared to its Continental sister parties, as recently claimed by Randall \& Sloam (2009).

Similarly, Stubager's analysis (2006) of the education cleavage in Denmark showed that the social democrats did not attract the highly educated after the programmatic adaption in the 1990s, but that the Social Liberals and the Socialist People's Party had their strongholds among these voters. Similarly, political commentators in Germany were sceptical about the SPD's future electoral prospects when the party started to mobilise on the same issues as the Greens recently did (Lachmann 2010). This does not benefit the SPD, as the voters prefer the 'original' party and not the copy. More turmoil for the SPD occurred after the former social democratic senator of finance for the State of Berlin, Thilo Sarrazin, published a book in which he criticised, among other things, Germany's immigration policy in recent decades, especially focusing on problems caused by immigrants from Muslim countries (Sarrazin 2010). The SPD's leadership immediately decided to launch an investigation and to terminate his party membership, as the book's theses were said to contradict the party's principles. However, this decision resulted in massive losses for the SPD in the polls, as many voters, SPD core voters in particular, agreed with Sarrazin's critique. One may thus speculate whether it is always fruitful for social democratic parties to emphasise distinct libertarian stances, as suggested by Giddens, Kitschelt, Häusermann and others, and which some did under Third Way labels. In combination with further welfare state recalibration, libertarian programmes may not be votewinners for mainstream social democratic parties, as they do not attract considerable voter shares beyond the proposed new target groups. A related aspect that should be examined in further research is whether competition with green, social liberal or left-libertarian parties has foreclosed the forging of new electoral alliances. These types of parties are likely to have absorbed considerable shares of these voter groups on the Continent before the social democrats directed their attention to them with the Third Way. A first systematic analysis accounting for electoral systems suggested that social democratic parties failed to attract the new target constituencies in countries applying PR with rather low thresholds, whereas this was more successful under majoritarian systems, such as those in Australia or the UK (Arndt 2011). It can be argued that the 
tougher competition for these voter segments in Continental Europe accounts for social democracy's failure to form new alignments with the Third Way, and its sacrifice of its core constituency. In this respect, the Third Way could be seen as costly innovation. 



\section{Appendices}

\section{Appendix A: Appendix to Chapter 4 (United Kingdom)}

\section{Data sources}

BES 1992, study no. 2981

BES 1997, study no. 3887

BES 2001, study no. 4619

BES 2005, study no. 5494

BES 2010, study no. not yet assigned

Description of variables used in analysis

Items and their wording for measurement of perception that the Labour Party looks after the interests of social groups in Tables 4.5, 4.6 and 4.7:

For 1997 election study, items labintwc and labintun have been used:

How closely do you think that the Labour Party looks after the interests of ...

[working class people], [unemployed people]
1 very closely
2 fairly closely
3 not very closely
4 not at all closely
8 don't know
9 not answered

For 2001 election study and 2005 election study, the following items have been used:

2001: items cq9a and cq9c

2005: items cq2a and cq2c 
Some people say that political parties look after the interests of some groups and are not so concerned about others. How well do you think that the Labour Party looks after the interests of the following groups? [a) working class people] [c) People who are unemployed or on benefits]
1 Very well
2 Fairly well
3 Not very well
4. Not at all well
8 Don't know

The categories 1 and 2 have been coded as Labour represents the interests of these groups (1); the categories 3 and 4 have been coded as Labour does not represent the interests of these groups (o); the categories 8 and 9 had been excluded from the analysis. The index was derived from the two dummy variables and coded as described in Section 4.5 of the text.

Table A1.1 Effects of voter group membership and perception of Labour Party on party choice in British General Election 2001. Coefficients from multinomial logistic regression models

\begin{tabular}{llcc}
\hline Party Choice & Variable & $\begin{array}{c}\text { Model without } \\
\text { controls }\end{array}$ & $\begin{array}{c}\text { Model with } \\
\text { controls }\end{array}$ \\
\hline Conservatives & $\begin{array}{l}\text { Voter group (Reference: non-core } \\
\text { constituency) }\end{array}$ & $0.71^{* *}$ & $0.75^{* *}$ \\
& Non-aligned core constituency & $-3.13^{* * *}$ & $-3.18^{* * *}$ \\
& Aligned core constituency & & \\
& Perception (Reference: Labour represents & & $0.82^{* * *}$ \\
& both groups) & $0.86^{* * *}$ & $1.76^{* * *}$ \\
& Labour does not represent one of the groups & $1.70^{* * *}$ & $0.02^{* * *}$ \\
& Labour does not represent both groups & & 0.20 \\
& Age (continuous) & & $-2.30^{* * *}$ \\
& Sex: men & $-0.71^{* * *}$ & \\
& Constant & & \\
Voter group (Reference: non-core & & $0.92^{* * *}$ \\
constituency) & $0.89^{* * *}$ & $-1.35^{* * *}$ \\
& Non-aligned core constituency & $-1.50^{* * *}$ & \\
& Aligned core constituency & & \\
& Perception (Reference Labour represents \\
& both groups) & &
\end{tabular}


Table A1.1 Effects of voter group membership and perception of Labour Party on party choice in British General Election 2001. Coefficients from multinomial logistic regression models

\begin{tabular}{|c|c|c|c|}
\hline Party Choice & Variable & $\begin{array}{l}\text { Model without } \\
\text { controls }\end{array}$ & $\begin{array}{l}\text { Model with } \\
\text { controls }\end{array}$ \\
\hline & Labour does not represent one of the groups & $0.62^{* * *}$ & $0.66^{* *}$ \\
\hline & Labour does not represent both groups & $1.71^{* * *}$ & $1.73^{* * *}$ \\
\hline & Age (continuous) & & -0.01 \\
\hline & Sex & & -0.24 \\
\hline & Constant & $-1.00^{* * *}$ & $-0.76 !$ \\
\hline \multirow[t]{9}{*}{ Other parties } & $\begin{array}{l}\text { Voter group (Reference: non-core } \\
\text { constituency) }\end{array}$ & & \\
\hline & Non-aligned core constituency & $0.96^{* *}$ & $0.92^{*}$ \\
\hline & Aligned core constituency & -0.52 & -0.49 \\
\hline & $\begin{array}{l}\text { Perception (Reference Labour represents } \\
\text { both groups) }\end{array}$ & & \\
\hline & Labour does not represent one of the groups & $0.99^{* *}$ & $0.95^{* *}$ \\
\hline & Labour does not represent both groups & $2.46^{* * *}$ & $2.47^{* * * *}$ \\
\hline & Age (continuous) & & $-0.02^{*}$ \\
\hline & Sex & & 0.02 \\
\hline & Constant & $-3.09^{* * *}$ & $-3.03^{* * *}$ \\
\hline \multirow[t]{12}{*}{ Non-voting } & $\begin{array}{l}\text { Voter group (Reference: non-core } \\
\text { constituency) }\end{array}$ & & \\
\hline & Non-aligned core constituency & $1.41^{* * *}$ & $1.39^{* * *}$ \\
\hline & Aligned core constituency & $-1.01^{* * *}$ & $-0.87^{* * *}$ \\
\hline & $\begin{array}{l}\text { Perception (Reference Labour represents } \\
\text { both groups) }\end{array}$ & & \\
\hline & Labour does not represent one of the groups & $0.73^{* * *}$ & $0.80^{* * *}$ \\
\hline & Labour does not represent both groups & $1.68^{* * *}$ & $1.78^{* * *}$ \\
\hline & Age (continuous) & & $-0.03^{* * *}$ \\
\hline & Sex & & 0.14 \\
\hline & Constant & $-0.90^{* * *}$ & -0.20 \\
\hline & $\mathrm{N}$ & 1688 & 1684 \\
\hline & Nagelkerke's $\mathrm{R}^{2}$ & 22.9 & 34.8 \\
\hline & $\mathrm{BIC}^{\prime}$ & -292.04 & -196.18 \\
\hline
\end{tabular}

Note: ***: significant at .001-level, **: significant at 0.01 -level, *: significant at 0.05 -level, !: significant at 0.1 -level. Reference category for party choice: Labour Party. Further control variables for region not shown. 
Table A1.2 Effects of voter group membership and perception of Labour Party on party choice in British General Election 2005. Coefficients from multinomial logistic regression models

\begin{tabular}{|c|c|c|c|}
\hline Party Choice & Variable & $\begin{array}{l}\text { Model without } \\
\text { controls }\end{array}$ & $\begin{array}{c}\text { Model } \\
\text { with controls }\end{array}$ \\
\hline \multirow[t]{10}{*}{ Conservative } & $\begin{array}{l}\text { Voter group (Reference: non-core } \\
\text { constituency) }\end{array}$ & & \\
\hline & Non-aligned core constituency & $-0.88^{* * *}$ & $-0.88^{* * * *}$ \\
\hline & Aligned core constituency & $-2.52^{* * *}$ & $-2.59^{* * *}$ \\
\hline & Core constituency: abstention in 2001 & $1.67 !$ & $1.66 !$ \\
\hline & $\begin{array}{l}\text { Perception (Reference: Labour represents } \\
\text { both groups) }\end{array}$ & & \\
\hline & $\begin{array}{l}\text { Labour does not represent one of the } \\
\text { groups }\end{array}$ & $1.32^{* * *}$ & $1.38^{* * *}$ \\
\hline & Labour does not represent both groups & $1.01^{* *}$ & $1.14^{* * *}$ \\
\hline & Age (continuous) & & $0.02^{* *}$ \\
\hline & Sex: men & & -0.11 \\
\hline & Constant & $-0.33^{*}$ & $-1.66^{* * *}$ \\
\hline \multirow[t]{10}{*}{ LibDems } & $\begin{array}{l}\text { Voter group (Reference: non-core } \\
\text { constituency) }\end{array}$ & & \\
\hline & Non-aligned core constituency & -0.31 & -0.26 \\
\hline & Aligned core constituency & $-1.27^{* *}$ & $-1.31^{* *}$ \\
\hline & Core constituency: abstention in 2001 & $1.86^{*}$ & $1.68 !$ \\
\hline & $\begin{array}{l}\text { Perception (Reference: Labour represents } \\
\text { both groups) }\end{array}$ & & \\
\hline & $\begin{array}{l}\text { Labour does not represent one of the } \\
\text { groups }\end{array}$ & $1.36^{* * *}$ & $1.40^{* * *}$ \\
\hline & Labour does not represent both groups & $1.63^{* * *}$ & $1.69 * * *$ \\
\hline & Age (continuous) & & 0.00 \\
\hline & Sex: men & & 0.06 \\
\hline & Constant & $-1.03^{* * *}$ & $-1.67^{* * *}$ \\
\hline \multirow[t]{5}{*}{ Other parties } & $\begin{array}{l}\text { Voter group (Reference: non-core } \\
\text { constituency) }\end{array}$ & & \\
\hline & Non-aligned core constituency & 0.47 & $0.51 !$ \\
\hline & Aligned core constituency & 0.37 & 0.51 \\
\hline & Core constituency: abstention in 2001 & $3.12^{* *}$ & $3.02^{* *}$ \\
\hline & $\begin{array}{l}\text { Perception (Reference: Labour represents } \\
\text { both groups) }\end{array}$ & & \\
\hline
\end{tabular}


Table A1.2 Effects of voter group membership and perception of Labour Party on party choice in British General Election 2005. Coefficients from multinomial logistic regression models

\begin{tabular}{|c|c|c|c|}
\hline Party Choice & Variable & $\begin{array}{l}\text { Model without } \\
\text { controls }\end{array}$ & $\begin{array}{c}\text { Model } \\
\text { with controls }\end{array}$ \\
\hline & $\begin{array}{l}\text { Labour does not represent one of the } \\
\text { groups }\end{array}$ & $1.53^{* * *}$ & $1.57^{* * *}$ \\
\hline & Labour does not represent both groups & $1.86^{* * *}$ & $1.83^{* * *}$ \\
\hline & Age (continuous) & & 0.01 \\
\hline & Sex: men & & $0.82^{* *}$ \\
\hline & Constant & $-3.06^{* * *}$ & $-5.24^{* * *}$ \\
\hline \multirow[t]{13}{*}{ Non-voting } & $\begin{array}{l}\text { Voter group (Reference: non-core } \\
\text { constituency) }\end{array}$ & & \\
\hline & Non-aligned core constituency & $0.72^{* * * *}$ & $0.70^{* * *}$ \\
\hline & Aligned core constituency & -0.52 & -0.42 \\
\hline & Core constituency: abstention in 2001 & $4.31^{* * *}$ & $4.08^{* * *}$ \\
\hline & $\begin{array}{l}\text { Perception (Reference: Labour represents } \\
\text { both groups) }\end{array}$ & & \\
\hline & $\begin{array}{l}\text { Labour does not represent one of the } \\
\text { groups }\end{array}$ & $1.15^{* * *}$ & $1.15^{* * *}$ \\
\hline & Labour does not represent both groups & $1.49^{* * *}$ & $1.52^{* * *}$ \\
\hline & Age (continuous) & & $-0.02^{* * *}$ \\
\hline & Sex: men & & $0.41^{*}$ \\
\hline & Constant & -1.02 & -0.32 \\
\hline & $\mathrm{N}$ & 1736 & 1735 \\
\hline & Nagelkerke's $\mathrm{R}^{2}$ & 20.6 & 32.5 \\
\hline & $\mathrm{BIC}^{\prime}$ & -227.85 & -130.29 \\
\hline
\end{tabular}

Note: ***: significant at .001- level, **: significant at 0.01 -level, *: significant at 0.05 -level, !: significant at 0.1 level. Reference category for party choice: Labour Party. Further control variables for region not shown. 


\section{Appendix B: Appendix to Chapter 5 (Germany)}

\section{Data sources}

German National Election Studies 1965-2005

Politbarometer 2002, ZA3849 \& ZA3850 [merged into one dataset] Politbarometer 2003, ZA4003 \& ZA4004 [merged into one dataset] Politbarometer 2005, ZA4258 \& ZA4259 [merged into one dataset] German Longitudinal Election Study (GLES), Pre-Release 1.3. [accessed at http://www.dgfw.info/daten.php]

Description of variables used in analysis Items and their wording for measurement of attitudes towards reform proposals in Table 5.5:

V192: Der Bundeskanzler hat eine Reihe von Vorschlägen zur Reform der sozialen Sicherungssysteme gemacht. Gehen Ihnen diese Vorschläge alles in allem gesehen...

(The Federal Chancellor has made a lot of proposals concerning the reform of the social security system. Altogether, do you think these proposals ...)

1. zu weit (go too far)

2. sind sie gerade richtig (are appropriate)

3. gehen Ihnen diese Vorschläge nicht weit genug ? (are not sufficient?)

V2oo: Es gibt auch den Vorschlag, das Arbeitslosengeld zu kürzen, um zusätzliche Anreize zu schaffen, auch schlechter bezahlte Jobs anzunehmen. (There is also a proposal to cut unemployment benefits to increase incentives to accept lower paid jobs.)

1. Finden Sie diesen Vorschlag gut, oder (Do you think that this is a good proposal, or)

2. finden Sie ihn nicht gut? (a bad proposal)

V236: Seit 2003 sind eine Reihe von Reformen in den Bereichen Gesundheit, Rente, Arbeitsmarkt und Steuern beschlossen worden. Ganz allgemein gefragt: Waren diese Maßnahmen...

(Since 2003 a lot of reforms concerning health, pensions, labour market and taxes have been implemented. Generally speaking: do you think these measures were...) 
1. eher richtig (generally right)

2. eher falsch (generally wrong)

V239: Seit Anfang des Jahres werden die bisherigen Arbeitslosenhilfe und die Sozialhilfe zum Arbeitslosengeld II („zwei“) zusammengefasst. Damit für Arbeitslose, die länger als ein Jahr arbeitslos, der Anreiz höher wird, wieder Arbeit anzunehmen, werden die Leistungen im Vergleich zur bisherigen Arbeitslosenhilfe in der Regel gekürzt. Finden Sie...

(Since the beginning of this year, benefits for the long-term unemployed and social assistance have been merged into a single scheme [Arbeitslosengeld II]. To increase incentives to accept a new job for persons who have been unemployed for more than a year, benefits have in most instances been cut compared to previous unemployment assistance. Do you think ...)

1. diese Kürzungen richtig (these cuts are appropriate)

2. Finden Sie die nicht richtig (these cuts are not appropriate)

V240: Langzeitarbeitslose müssen jetzt eine Arbeit annehmen, auch wenn die Bezahlung bis zu 30 Prozent unter dem jeweiligen Lohnniveau liegt. Finden Sie das...

(The long-term unemployed now have to accept a job, even if the remuneration is up to 30 per cent below the actual wage level. Do you think this is ...)

1. richtig (appropriate)

2. Finden Sie das nicht richtig (not appropriate)

Items and their wording for assessment of government's performance in Table 5.7:

V221: Was meinen Sie, macht die Bundesregierung ihre Arbeit alles in allem gesehen...

(On balance, do you think the federal government does a)

1. eher gut (good job)

2. eher schlecht (bad job) 
Items and their wording for measurement of attitudes towards reforms in Table 5.8:

Variable V236 as described for Table 5.5 has been used as the dependent variable.

Items and their wording for measurement of attitudes towards reforms in Table 5.9:

Vn158_C1-vn158_C3: Und warum haben Sie diese Partei gewählt? Bitte nennen Sie mir die wichtigsten Gründe.

(And why did you choose this party? Please specify the most important reasons)

Coded as named if respondent named the following reasons for his vote decision in items Vn158_C1-vn158_C3 'Sozialpolitik' (Soz. Gerechtigkeit, Hartz IV, sozialere Politik, Mindestloehne etc.)

Table A2.1 Effects of voter group membership and assessment of government's performance on party choice in federal election 2002. Coefficients from multinomial logistic regression models

\begin{tabular}{llc}
\hline Party Choice & Variable & Model without controls \\
\hline CDU/CSU & Voter group (Reference: non-core constituency) & \\
& Non-aligned core constituency & $1.01^{* * *}$ \\
& Aligned core constituency & $-1.57^{* * *}$ \\
& Government: bad job & $2.31^{* * *}$ \\
Constant & $-0.94^{* * *}$ \\
PDS & Voter group (Reference: non-core constituency) & \\
& Non-aligned core constituency & $1.01^{* * *}$ \\
& Aligned core constituency & $-1.02^{* * *}$ \\
& Government: bad job & $1.13^{* * *}$ \\
Constant & $-1.55^{* * *}$ \\
Greens & Voter group (Reference: non-core constituency) & \\
& Non-aligned core constituency & 0.07 \\
& Aligned core constituency & $-1.49^{* * *}$ \\
& Government: bad job & $0.32^{*}$ \\
Constant & $-1.70^{* * *}$
\end{tabular}


Table A2.1 Effects of voter group membership and assessment of government's performance on party choice in federal election 2002. Coefficients from multinomial logistic regression models

\begin{tabular}{llc}
\hline Party Choice & Variable & Model without controls \\
\hline FDP & Voter group (Reference: non-core constituency) & \\
& Non-aligned core constituency & $0.45^{* *}$ \\
& Aligned core constituency & $-1.33^{* * *}$ \\
& Government: bad job & $1.88^{* * *}$ \\
& Constant & $-2.17^{* * *}$ \\
Non-voting & Voter group (Reference: non-core constituency) & \\
& Non-aligned core constituency & $2.02^{* * *}$ \\
& Aligned core constituency & $-0.63^{* * *}$ \\
& Government: bad job & $2.04^{* * *}$ \\
& Constant & $-2.44^{* * *}$ \\
\hline N & 8525 \\
& Nagelkerke's $R^{2}$ & 32.4 \\
\hline BIC' & -2991.75 \\
\hline
\end{tabular}

Note: ***: significant at .001- level, **: significant at 0.01-level, *: significant at 0.05-level, !: significant at 0.1 level. Reference category for party choice: SPD. Other parties not shown.

Table A2.2 Effects of voter group membership and assessment of welfare state reforms on party choice in federal election 2005. Coefficients from multinomial logistic regression models

\begin{tabular}{llcc}
\hline Party Choice & Variable & $\begin{array}{c}\text { Without } \\
\text { controls }\end{array}$ & $\begin{array}{c}\text { With } \\
\text { controls }\end{array}$ \\
\hline CDU/CSU & $\begin{array}{l}\text { Voter group (Reference: non-core } \\
\text { constituency) }\end{array}$ & \\
& Non-aligned core constituency & $2.14^{* * *}$ & $2.40^{* *}$ \\
& Aligned core constituency & $-2.09^{* * *}$ & $-2.13^{* * *}$ \\
& Core constituency: aligned with PDS 2002 & -1.30 & -1.28 \\
& Core constituency: abstention in 2002 & 0.02 & 0.02 \\
& Sex: men & & 0.24 \\
& Religion (reference: no/other confession) & & \\
& Catholic & & $0.95^{* * *}$ \\
& Protestant & & $0.45^{*}$ \\
& Reforms: wrong & $0.95^{* * *}$ & $1.04^{* * *}$ \\
& Constant & 0.09 & -0.66
\end{tabular}


Table A2.2 Effects of voter group membership and assessment of welfare state reforms on party choice in federal election 2005. Coefficients from multinomial logistic regression models

\begin{tabular}{|c|c|c|c|}
\hline Party Choice & Variable & $\begin{array}{l}\text { Without } \\
\text { controls }\end{array}$ & $\begin{array}{l}\text { With } \\
\text { controls }\end{array}$ \\
\hline \multirow[t]{11}{*}{ Left Party } & $\begin{array}{l}\text { Voter group (Reference: non-core } \\
\text { constituency) }\end{array}$ & & \\
\hline & Non-aligned core constituency & $1.16^{*}$ & $1.43^{* *}$ \\
\hline & Aligned core constituency & -0.38 & -0.30 \\
\hline & Core constituency: aligned with PDS 2002 & $4.00^{* * *}$ & $3.47^{* * *}$ \\
\hline & Core constituency: abstention in 2002 & $1.90^{* * *}$ & $1.78^{* * *}$ \\
\hline & Sex: men & & 0.23 \\
\hline & Religion (reference: no/other confession) & & \\
\hline & Catholic & & $-0.95^{* *}$ \\
\hline & Protestant & & $-0.78^{* *}$ \\
\hline & Reforms: wrong & $1.36^{* * *}$ & $1.38^{* * * *}$ \\
\hline & Constant & $-2.03^{* * *}$ & $-1.23^{* * *}$ \\
\hline \multirow[t]{11}{*}{ Greens } & $\begin{array}{l}\text { Voter group (Reference: non-core } \\
\text { constituency) }\end{array}$ & & \\
\hline & Non-aligned core constituency & $2.09 * * *$ & $2.23^{* * *}$ \\
\hline & Aligned core constituency & $-1.87^{* * *}$ & $-1.85^{* * *}$ \\
\hline & Core constituency: aligned with PDS 2002 & 0.50 & 0.29 \\
\hline & Core constituency: abstention in 2002 & -0.13 & -0.43 \\
\hline & Sex: men & & $-0.52^{* *}$ \\
\hline & Religion (reference: no/other confession) & & \\
\hline & Catholic & & -0.15 \\
\hline & Protestant & & -0.37 \\
\hline & Reforms: wrong & 0.07 & -0.01 \\
\hline & Constant & $-1.00^{* * *}$ & -0.47 \\
\hline \multirow[t]{6}{*}{ FDP } & $\begin{array}{l}\text { Voter group (Reference: non-core } \\
\text { constituency) }\end{array}$ & & \\
\hline & Non-aligned core constituency & $1.77^{* * *}$ & $1.94^{* * *}$ \\
\hline & Aligned core constituency & $-2.11^{* * *}$ & $-2.17^{* * *}$ \\
\hline & Core constituency: aligned with PDS 2002 & n.e. & n.e. \\
\hline & Core constituency: abstention in 2002 & n.e. & n.e. \\
\hline & Sex:men & & -0.02 \\
\hline
\end{tabular}


Table A2.2 Effects of voter group membership and assessment of welfare state reforms on party choice in federal election 2005. Coefficients from multinomial logistic regression models

\begin{tabular}{|c|c|c|c|}
\hline Party Choice & Variable & $\begin{array}{l}\text { Without } \\
\text { controls }\end{array}$ & $\begin{array}{c}\text { With } \\
\text { controls }\end{array}$ \\
\hline & Religion (reference: no/other confession) & & \\
\hline & Catholic & & 0.33 \\
\hline & Protestant & & -0.07 \\
\hline & Reforms: wrong & $0.57^{*}$ & $0.58^{*}$ \\
\hline & Constant & $-1.65^{* * *}$ & $-1.49^{* * *}$ \\
\hline \multirow[t]{14}{*}{ Non-voting } & $\begin{array}{l}\text { Voter group (Reference: non-core } \\
\text { constituency) }\end{array}$ & & \\
\hline & Non-aligned core constituency & $1.90^{* * *}$ & $2.04^{* * *}$ \\
\hline & Aligned core constituency & $-0.79 * *$ & $-0.88^{* *}$ \\
\hline & Core constituency: aligned with PDS 2002 & $1.73^{*}$ & $1.41 !$ \\
\hline & Core constituency: abstention in 2001 & $-3.29 * * *$ & $3.01^{* * *}$ \\
\hline & Sex: men & & 0.00 \\
\hline & Religion (reference: no/other confession) & & \\
\hline & Catholic & & -0.11 \\
\hline & Protestant & & -0.29 \\
\hline & Reforms: wrong & $1.55^{* * *}$ & $1.54^{* * * *}$ \\
\hline & Constant & $-1.77^{* * *}$ & \\
\hline & $\mathrm{N}$ & 2354 & 2345 \\
\hline & Nagelkerke's $\mathrm{R}^{2}$ & 33.1 & 41.4 \\
\hline & $\mathrm{BIC}^{\prime}$ & -716.48 & -526.00 \\
\hline
\end{tabular}

Note: ***: significant at .001- level, **: significant at 0.01-level, *: significant at 0.05-level, !:significant at 0.10-level. n.e.: not estimated parameter due to empty cells in data matrix. Reference category for party choice: SPD. Other parties not shown. Further control variables for age categories not shown. 


\title{
Appendix C: Appendix to Chapter 6 (Denmark)
}

\section{Data sources}

Danish Election Studies 1973-2005

\begin{abstract}
Description of variables used in analysis
Items and their wording for measurement of attitudes towards reform proposals in Table 6.5:
\end{abstract}

There is disagreement over the ways to fight unemployment, and there are many proposals. People disagree both as to whether these proposals will work, and whether they are good or bad because they may also have other effects. I shall now read some proposals to you and ask whether you think it is a good or bad proposal, taking everything into account

V164: Forcing the unoccupied to take work far from where they live V167: Setting up individual plans of action for each unemployed V168: Limiting young people's access to unemployment benefits V169 Reducing benefits after one year of unemployment
1. Good proposal
2. Bad proposal
3. Don't know

Items and their wording for measurement of attitudes towards government's social policy in Table 6.7:

V58: Jeg vil nu læse en række problemer op for Dem, og jeg vil gerne høre, hvem De mener, er bedst til at løse problemet; en socialdemokratisk ledet regering, eller en borgerlig regering?

I shall now read some problems to you, and I want to know who you think is better at solving the problem: the present government led by the Social Democrats, or a bourgeois government?

Til at sikre den rette balance mellem skattetryk og social tryghed? (Secure the right balance between taxes and welfare)

1. Socialdemokratisk ledet regering (Present social democratic government)

2. Borgerlig regering (Bourgeois government)

3. Ingen forskel (No difference) 
Assessing a social democratic government to perform a balanced policy is coded as 1 and other categories as 0.

V106: Indvandring udgør en alvorlig trussel mod vores nationale egenart.

(Immigration constitutes a serious threat to our national culture)

1. Helt enig (Totally agree)

2. Nærmest enig (Partly agree)

3. Hverken/eller (Neither agree nor disagree)

4. Nærmest uenig (Partly disagree)

5. Helt uenig (Totally disagree)

Coded as dummy variable in analysis: respondents agreeing fully or partly with the statement 'Immigration constitutes a serious threat to our national culture' are coded as 1, others are coded as o. Other answers such as 'don't know' have been treated as missing values.

Items and their wording for measurement of attitudes towards government's social policy in Table 6.8:

V62: Hvor godt mener De, at Nyrup-regeringen har håndteret de følgende områder i de sidste 3-4 år? [Velfærden].

How well has the Nyrup-government handled the following areas [Welfare] in the past 3-4 years?

1. Meget godt (very well)

2. Godt (well)

3. Hverken godt eller dårligt (neither well nor poorly)

4. Dårligt (poorly)

5. Meget dårligt (very poorly)

Assessment welfare policy under Nyrup Rasmussen for 2001 election: Dummy variable, responses for poorly and very poorly were recoded to 1 indicating poorly, others to o indicating neither/well.

V105: Indvandring udgør en alvorlig trussel mod vores nationale egenart. (Immigration constitutes a serious threat to our national culture) 
1. Helt enig (Totally agree)

2. Nærmest enig (Partly agree)

3. Hverken/eller (Neither agree nor disagree)

4. Nærmest uenig (Partly disagree)

5. Helt uenig (Totally disagree)

Coded as dummy variable in analysis: respondents agreeing fully or partly with the statement 'Immigration constitutes a serious threat to our national culture' are coded as 1, others are coded as o. Other answers such as 'don't know' have been treated as missing values.

Table A3.1 Effects of voter group membership and social policy attitudes on party choice in Danish General Election 1998. Coefficients from multinomial logistic regression models

\begin{tabular}{|c|c|c|c|}
\hline Party Choice & Variable & $\begin{array}{l}\text { Without } \\
\text { controls }\end{array}$ & $\begin{array}{c}\text { With } \\
\text { controls }\end{array}$ \\
\hline \multirow[t]{7}{*}{ Social Liberals } & $\begin{array}{l}\text { Voter group (Reference: non-core } \\
\text { constituency) }\end{array}$ & & \\
\hline & Non-aligned core constituency & $0.51 !$ & 0.40 \\
\hline & Aligned core constituency & $-2.31^{* * *}$ & $-2.28^{* * *}$ \\
\hline & Balance tax-welfare: SD government & 0.05 & -0.15 \\
\hline & Age (continuous) & & $0.03^{* * *}$ \\
\hline & Sex: men & & 0.18 \\
\hline & Constant & $-2.09^{* * *}$ & $-2.67^{* * *}$ \\
\hline \multirow[t]{7}{*}{ Conservatives } & $\begin{array}{l}\text { Voter group (Reference: non-core } \\
\text { constituency) }\end{array}$ & & \\
\hline & Non-aligned core constituency & $0.52^{*}$ & $0.55^{*}$ \\
\hline & Aligned core constituency & $-3.31^{* * *}$ & $-3.34 * * *$ \\
\hline & Balance tax-welfare: SD government & $-3.43^{* * *}$ & $-3.53^{* * *}$ \\
\hline & Age (continuous) & & 0.00 \\
\hline & Sex: men & & 0.30 \\
\hline & Constant & $0.51^{*}$ & $0.80^{*}$ \\
\hline \multirow[t]{5}{*}{ Venstre } & $\begin{array}{l}\text { Voter group (Reference: non-core } \\
\text { constituency) }\end{array}$ & & \\
\hline & Non-aligned core constituency & $0.89 * * *$ & $0.75^{* *}$ \\
\hline & Aligned core constituency & $-4.15^{* * *}$ & $-4.38^{* * *}$ \\
\hline & Balance tax-welfare: SD government & $-3.54^{* * *}$ & $-3.57^{* * *}$ \\
\hline & Age (continuous) & & $0.01 *$ \\
\hline
\end{tabular}


Table A3.1 Effects of voter group membership and social policy attitudes on party choice in Danish General Election 1998. Coefficients from multinomial logistic regression models

\begin{tabular}{|c|c|c|c|}
\hline Party Choice & Variable & $\begin{array}{l}\text { Without } \\
\text { controls }\end{array}$ & $\begin{array}{l}\text { With } \\
\text { controls }\end{array}$ \\
\hline & Sex: men & & $0.50^{* *}$ \\
\hline & Constant & $1.43^{* * *}$ & 0.55 \\
\hline \multirow[t]{7}{*}{ SF } & $\begin{array}{l}\text { Voter group (Reference: non-core } \\
\text { constituency) }\end{array}$ & & \\
\hline & Non-aligned core constituency & $1.15^{* * * *}$ & $0.95^{* * *}$ \\
\hline & Aligned core constituency & $-1.32^{* * *}$ & $-1.37^{* * *}$ \\
\hline & Balance tax-welfare: SD government & 0.00 & -0.07 \\
\hline & Age (continuous) & & $0.02^{* * *}$ \\
\hline & Sex: men & & -0.25 \\
\hline & Constant & $-1.59^{* * *}$ & $-2.04^{* * *}$ \\
\hline \multirow[t]{7}{*}{$\begin{array}{l}\text { Danish People's } \\
\text { Party }\end{array}$} & $\begin{array}{l}\text { Voter group (Reference: non-core } \\
\text { constituency) }\end{array}$ & & \\
\hline & Non-aligned core constituency & $1.19^{* * *}$ & $1.17^{* * *}$ \\
\hline & Aligned core constituency & $-2.33^{* * *}$ & $-2.41^{* * *}$ \\
\hline & Balance tax-welfare: SD government & $-3.31^{* * *}$ & $-3.34^{* * * *}$ \\
\hline & Age (continuous) & & 0.01 \\
\hline & Sex:men & & $0.59^{*}$ \\
\hline & Constant & -0.06 & -0.42 \\
\hline \multirow[t]{10}{*}{ Non-voting } & $\begin{array}{l}\text { Voter group (Reference: non-core } \\
\text { constituency) }\end{array}$ & & \\
\hline & Non-aligned core constituency & $1.00^{* *}$ & $0.82^{*}$ \\
\hline & Aligned core constituency & $-1.27^{* *}$ & $-1.40^{* *}$ \\
\hline & Balance tax-welfare: SD government & $-0.84^{* *}$ & $-0.89 * *$ \\
\hline & Age (continuous) & & 0.01 \\
\hline & Sex: men & & -0.12 \\
\hline & Constant & $-1.68^{* * *}$ & $-2.37^{* * *}$ \\
\hline & $\mathrm{N}$ & 1749 & 1744 \\
\hline & Nagelkerke's $\mathrm{R}^{2}$ & 49.6 & 54.6 \\
\hline & $\mathrm{BIC}^{\prime}$ & -972.82 & -783.48 \\
\hline
\end{tabular}

Note: ***: significant at .001- level, ${ }^{* *}$ : significant at 0.01-level, ${ }^{*}$ : significant at 0.05 -level, !! significant at 0.1 -level Reference category for party choice. Unity List and other parties not shown. Further control variables for region not shown. 
Table A3.2 Effects of voter group membership, attitudes towards immigration and assessment of government's social policy on party choice in Danish General Election 2001. Coefficients from multinomial logistic regression models

\begin{tabular}{|c|c|c|c|}
\hline Party Choice & Variable & $\begin{array}{l}\text { Without } \\
\text { controls }\end{array}$ & $\begin{array}{l}\text { With } \\
\text { controls }\end{array}$ \\
\hline \multirow[t]{9}{*}{ Social Liberals } & $\begin{array}{l}\text { Voter group (Reference: non-core } \\
\text { constituency) }\end{array}$ & & \\
\hline & Non-aligned core constituency & 0.28 & 0.38 \\
\hline & Aligned core constituency & $\begin{array}{l}-34.20 \\
\text { (unstable } \\
\text { estimate) }\end{array}$ & $\begin{array}{l}-35.08 \\
\text { (unstable } \\
\text { estimate) }\end{array}$ \\
\hline & Welfare policy: neither & 0.34 & 0.34 \\
\hline & Welfare policy: bad & 0.61 & 0.50 \\
\hline & Immigration is threat & $-2.93 * *$ & $-2.91 * *$ \\
\hline & Age (continuous) & - & 0.02 \\
\hline & Sex: men & - & -0.09 \\
\hline & Constant & $-0.91^{* * *}$ & -0.84 \\
\hline \multirow[t]{9}{*}{ Conservatives } & $\begin{array}{l}\text { Voter group (Reference: non-core } \\
\text { constituency) }\end{array}$ & & \\
\hline & Non-aligned core constituency & $0.65 !$ & $0.71^{*}$ \\
\hline & Aligned core constituency & $-1.75^{* * *}$ & $-1.80^{* * *}$ \\
\hline & Welfare policy: neither & $1.02^{* *}$ & $1.01^{* *}$ \\
\hline & Welfare policy: bad & $2.28^{* * *}$ & $2.29^{* * *}$ \\
\hline & Immigration is threat & 0.08 & 0.06 \\
\hline & Age (continuous) & - & 0.00 \\
\hline & Sex: men & - & $0.81^{* *}$ \\
\hline & Constant & $-1.45^{* * *}$ & $-2.06^{* *}$ \\
\hline \multirow[t]{9}{*}{ Venstre } & $\begin{array}{l}\text { Voter group (Reference: non-core } \\
\text { constituency) }\end{array}$ & & \\
\hline & Non-aligned core constituency & $0.82^{* *}$ & $0.83^{* *}$ \\
\hline & Aligned core constituency & $-1.82^{* * *}$ & $-1.87^{* * *}$ \\
\hline & Welfare policy: neither & $1.37^{* * *}$ & $1.35^{* * *}$ \\
\hline & Welfare policy: bad & $2.55^{* * *}$ & $2.55^{* * *}$ \\
\hline & Immigration is threat & $0.62^{* *}$ & $0.61 * *$ \\
\hline & Age (continuous) & - & -0.01 \\
\hline & Sex: men & - & $0.61^{* *}$ \\
\hline & Constant & $-0.66^{* * *}$ & -0.37 \\
\hline \multirow[t]{2}{*}{ SF } & $\begin{array}{l}\text { Voter group (Reference: non-core } \\
\text { constituency) }\end{array}$ & & \\
\hline & Non-aligned core constituency & $0.76^{*}$ & $0.83^{*}$ \\
\hline
\end{tabular}


Table A3.2 Effects of voter group membership, attitudes towards immigration and assessment of government's social policy on party choice in Danish General Election 2001. Coefficients from multinomial logistic regression models

\begin{tabular}{|c|c|c|c|}
\hline Party Choice & Variable & $\begin{array}{l}\text { Without } \\
\text { controls }\end{array}$ & $\begin{array}{l}\text { With } \\
\text { controls }\end{array}$ \\
\hline & Aligned core constituency & $-1.35^{* *}$ & $-1.26^{* *}$ \\
\hline & Welfare policy: neither & 0.40 & 0.40 \\
\hline & Welfare policy: bad & 0.85 & 0.79 \\
\hline & Immigration is threat & $-0.98^{*}$ & $-0.96^{*}$ \\
\hline & Age (continuous) & - & $0.02^{*}$ \\
\hline & Sex: men & - & -0.28 \\
\hline & Constant & $-1.24^{* * *}$ & $-1.63^{* *}$ \\
\hline \multirow[t]{9}{*}{$\begin{array}{l}\text { Danish People's } \\
\text { Party }\end{array}$} & $\begin{array}{l}\text { Voter group (Reference: non-core } \\
\text { constituency) }\end{array}$ & & \\
\hline & Non-aligned core constituency & $1.44^{* * *}$ & $1.45^{* * *}$ \\
\hline & Aligned core constituency & $-0.95^{*}$ & $-1.06^{* *}$ \\
\hline & Welfare policy: neither & $1.82^{* * *}$ & $1.82^{* * *}$ \\
\hline & Welfare policy: bad & $2.86^{* * *}$ & $2.85^{* * *}$ \\
\hline & Immigration is threat & $2.05^{* * *}$ & $2.10^{* * *}$ \\
\hline & Age (continuous) & - & $-0.03^{*}$ \\
\hline & Sex: men & - & $0.96^{*}$ \\
\hline & Constant & $-3.23^{* * * *}$ & $-2.63^{* * *}$ \\
\hline \multirow[t]{12}{*}{ Non-voting } & $\begin{array}{l}\text { Voter group (Reference: non-core } \\
\text { constituency) }\end{array}$ & & \\
\hline & Non-aligned core constituency & $1.92^{* * *}$ & $1.62^{* * *}$ \\
\hline & Aligned core constituency & -0.11 & -0.27 \\
\hline & Welfare policy: neither & $1.36^{* * * *}$ & $1.39^{* * *}$ \\
\hline & Welfare policy: bad & $1.89^{* *}$ & $1.97^{* *}$ \\
\hline & Immigration is threat & 0.27 & 0.26 \\
\hline & Age (continuous) & - & $-0.10^{* * *}$ \\
\hline & Sex: men & - & $0.58 !$ \\
\hline & Constant & $-3.08^{* * *}$ & 0.38 \\
\hline & $\mathrm{N}$ & 1153 & 1153 \\
\hline & Nagelkerke's $\mathrm{R}^{2}$ & 38.9 & 47.0 \\
\hline & $\mathrm{BIC}^{\prime}$ & -267.68 & -86.39 \\
\hline
\end{tabular}

Note: ${ }^{* * *}$ : significant at .001 - level, ${ }^{* *}$ : significant at 0.01 -level, ${ }^{*}$ : significant at 0.05 -level, !: significant at 0.1 -level Reference category for party choice. Unity List and other parties not shown. Further control variables for region not shown. 


\section{Appendix D: Appendix to Chapter 7 (Sweden)}

\section{Data sources}

Riks-SOM 1996 survey, study no. SND 0589

Riks-SOM 1998 survey, study no. SND 0739

Riks-SOM 2002 survey, study no. SND 0801

VALU 1998 - SVT exit poll survey parliamentary election 1998, study no. SND 0630

VALU 2002 - SVT exit poll survey parliamentary election 2002, study no. SND 0787

Description of variables used in analysis

Items and their wording for measurement of attitudes towards reform proposals in Table 7.5:

Nedan finns ett antal förslag som har förekommit i den politiska debatten. Vilken är Din åsikt om vart och ett av dem?

(Below are some proposals that appeared in the political debate. What is your opinion on each of these proposals?)

V127: Minska den offentliga sektorn (Reduce the size of the public sector)

1. Mycket bra förslag (Very good proposal)

2. Ganska bra förslag (Good proposal)

3. Varken bra eller dåligt förslag (Neither good nor bad)

4. Ganska dåligt förslag (Bad proposal)

5. Mycket dåligt förslag (Very bad proposal)

Categories 1 and 2 have been merged into 'good proposal' and 4 and 5 into 'bad proposal' in Table 4.5 .

Här finns ett antal förslag som förekommit den politiska debatten om arbetslösheten. Vilken är Din åsikt om vart och ett av dem?

(Here are some proposals that appeared in the political debate on unemployment. What is your opinion on each of these proposals?)

V143: Satsa mer på beredskapsarbeten/ungdomspraktik/ALU etc (Increase use of ALMP and job creation schemes)

V146: Sänka arbetslöshetserstatningen (Reduce unemployment benefits) 
V270 Tidsbegränsa rätten till arbetslöshetsersättning (introduce limited eligibility period for unemployment benefits)

1. Mycket bra förslag (Very good proposal)

2. Ganska bra förslag (Good proposal)

3. Varken bra eller dåligt förslag (Neither good nor bad)

4. Ganska dåligt förslag (Bad proposal)

5. Mycket dåligt förslag (Very bad proposal)

Categories 1 and 2 have been merged into 'good proposal' and 4 and 5 into 'bad proposal' in Table 4.5.

V245: Vad tycker Du om den politik som bedrivs i Sverige inom följande samhällsområden? [Arbetslösheten]

(What do you think about the policy that is currently pursued in Sweden concerning the following political issue [unemployment]?)

1. Mycket bra politik (Very good policy)

2. Ganska bra politik (Good policy)

3. Varken bra eller dåligt politik (Neither good nor bad)

4. Ganska dåligt politik (Bad policy)

5. Mycket dåligt politik (Very bad policy)

Categories 1 and 2 have been merged into 'good policy' and 4 and 5 into 'bad policy' in Table 7.5.

Items and their wording for measurement of attitudes towards reform proposals in Table 7.7:

V44: Summarised grade on politics - Social Democrats. Which summarised grade would you like to give the politics of the different parties? [Social Democrats]

1. Very good

2. Fairly good

3. Passed

4. Fairly bad

5. Very bad

Categories 1, 2 and 3 have been re-coded into 'well/neither' and 4 and 5 into 'badly' for the empirical analysis presented in Table 7.7. 
Items and their wording for measurement of attitudes towards reform proposals in Table 7.9:

F85a: Sänka arbetslöshetserstatningen (Reduce unemployment benefits)

1. Mycket bra förslag (Very good proposal)

2. Ganska bra förslag (Good proposal)

3. Varken bra eller dåligt förslag (Neither good nor bad)

4 Ganska dåligt förslag (Bad proposal)

5. Mycket dåligt förslag (Very bad proposal)

Categories 1, 2 and 3 have been merged into category 'reform-minded' and 4 and 5 into 'reform-averse' for the analysis presented in Table 7.9.

Table A4.1 Effects of voter group membership and assessment of SAP policy on party choice in Swedish Riksdag Election 1998. Coefficients from multinomial logistic regression models

\begin{tabular}{|c|c|c|c|}
\hline Party Choice & Variable & $\begin{array}{l}\text { Model without } \\
\text { controls }\end{array}$ & $\begin{array}{l}\text { Model with } \\
\text { controls }\end{array}$ \\
\hline \multirow[t]{11}{*}{$\begin{array}{l}\text { Left Party } \\
\text { (Vänsterpartiet) }\end{array}$} & $\begin{array}{l}\text { Voter group (Reference: non-core } \\
\text { constituency) }\end{array}$ & & \\
\hline & Non-aligned core constituency & $1.63^{* * *}$ & $1.55^{* * *}$ \\
\hline & Aligned core constituency & $-0.67^{* * *}$ & $-0.66^{* * *}$ \\
\hline & Assessment SAP policy: bad & $2.50^{* * * *}$ & $2.51^{* * * *}$ \\
\hline & Age (continuous) & & $0.01^{* * *}$ \\
\hline & Sex: men & & $-0.38^{* * *}$ \\
\hline & Region (Reference: Stockholm) & & \\
\hline & Lund & & 0.12 \\
\hline & Göteborg & & $0.44^{* * *}$ \\
\hline & Sundsvall & & $0.39^{* *}$ \\
\hline & Constant & $-1.27^{* * *}$ & $-29.52^{* * *}$ \\
\hline \multirow[t]{8}{*}{$\begin{array}{l}\text { Conservatives } \\
\text { (Moderaterna) }\end{array}$} & $\begin{array}{l}\text { Voter group (Reference: non-core } \\
\text { constituency) }\end{array}$ & & \\
\hline & Non-aligned core constituency & $0.70^{* * * *}$ & $0.66^{* * *}$ \\
\hline & Aligned core constituency & $-3.30^{* * *}$ & $-3.19^{* * *}$ \\
\hline & Assessment SAP policy: bad & $4.27^{* * *}$ & $4.25^{* * *}$ \\
\hline & Age (continuous) & & $0.01 *$ \\
\hline & Sex: men & & 0.10 \\
\hline & Region (Reference: Stockholm) & & \\
\hline & Lund & & $-0.24^{*}$ \\
\hline
\end{tabular}


Table A4.1 Effects of voter group membership and assessment of SAP policy on party choice in Swedish Riksdag Election 1998. Coefficients from multinomial logistic regression models

\begin{tabular}{|c|c|c|c|}
\hline Party Choice & Variable & $\begin{array}{l}\text { Model without } \\
\text { controls }\end{array}$ & $\begin{array}{l}\text { Model with } \\
\text { controls }\end{array}$ \\
\hline & Göteborg & & $-0.40^{* * *}$ \\
\hline & Sundsvall & & $-1.12^{* * *}$ \\
\hline & Constant & $-0.72^{* * *}$ & $-11.72^{*}$ \\
\hline \multirow[t]{11}{*}{ Centre Party } & $\begin{array}{l}\text { Voter group (Reference: non-core } \\
\text { constituency) }\end{array}$ & & \\
\hline & Non-aligned core constituency & $0.78^{* * *}$ & $0.76^{* * *}$ \\
\hline & Aligned core constituency & $-2.95^{* * *}$ & $-3.02^{* * *}$ \\
\hline & Assessment SAP policy: bad & $3.11^{* * *}$ & $3.09^{* * *}$ \\
\hline & Age (continuous) & & $-0.01^{* *}$ \\
\hline & Sex: men & & -0.11 \\
\hline & Region (Reference: Stockholm) & & \\
\hline & Lund & & $0.48^{* *}$ \\
\hline & Göteborg & & 0.23 \\
\hline & Sundsvall & & $0.32 !$ \\
\hline & Constant & $-1.86^{* * *}$ & $19.85^{*}$ \\
\hline \multirow[t]{11}{*}{$\begin{array}{l}\text { Liberals } \\
\text { (Folkpartiet) }\end{array}$} & $\begin{array}{l}\text { Voter group (Reference: non-core } \\
\text { constituency) }\end{array}$ & & \\
\hline & Non-aligned core constituency & $0.83^{* * *}$ & $0.79^{* * *}$ \\
\hline & Aligned core constituency & $-2.82^{* * *}$ & $-2.72^{* * *}$ \\
\hline & Assessment SAP policy: bad & 3.71 & $3.68^{* * *}$ \\
\hline & Age (continouos) & & -0.00 \\
\hline & Sex: men & & $0.26^{*}$ \\
\hline & Region (Reference: Stockholm) & & \\
\hline & Lund & & $-0.42^{* *}$ \\
\hline & Göteborg & & $-0.57^{* *}$ \\
\hline & Sundsvall & & $-0.99 * * *$ \\
\hline & Constant & $-1.80^{* * *}$ & 1.28 \\
\hline \multirow[t]{5}{*}{$\begin{array}{l}\text { Christian } \\
\text { Democrats }\end{array}$} & $\begin{array}{l}\text { Voter group (Reference: non-core } \\
\text { constituency) }\end{array}$ & & \\
\hline & Non-aligned core constituency & $1.01^{* * *}$ & $1.00^{* * *}$ \\
\hline & Aligned core constituency & $-2.45^{* * *}$ & $-2.45^{* * *}$ \\
\hline & Assessment SAP policy: bad & $3.92^{* * *}$ & $3.89^{* * *}$ \\
\hline & Age (continouos) & & $-0.02^{* * *}$ \\
\hline
\end{tabular}


Table A4.1 Effects of voter group membership and assessment of SAP policy on party choice in Swedish Riksdag Election 1998. Coefficients from multinomial logistic regression models

\begin{tabular}{|c|c|c|c|}
\hline Party Choice & Variable & $\begin{array}{l}\text { Model without } \\
\text { controls }\end{array}$ & $\begin{array}{l}\text { Model with } \\
\text { controls }\end{array}$ \\
\hline & Sex: men & & $-0.32^{* *}$ \\
\hline & Region (Reference: Stockholm) & & \\
\hline & Lund & & -0.08 \\
\hline & Göteborg & & $0.38^{* *}$ \\
\hline & Sundsvall & & $-0.44^{* *}$ \\
\hline & Constant & -1.51 & $31.02^{* * *}$ \\
\hline \multirow[t]{14}{*}{ Greens } & $\begin{array}{l}\text { Voter group (Reference: non-core } \\
\text { constituency) }\end{array}$ & & \\
\hline & Non-aligned core constituency & $1.23^{* * *}$ & $1.06^{* * *}$ \\
\hline & Aligned core constituency & $-2.03^{* *}$ & $-2.08^{* * *}$ \\
\hline & Assessment SAP policy: bad & $2.86^{* * *}$ & $2.83^{* * * *}$ \\
\hline & Age (continouos) & & $0.03^{* * *}$ \\
\hline & Sex: men & & $-0.70^{* * *}$ \\
\hline & Region (Reference: Stockholm) & & \\
\hline & Lund & & -0.04 \\
\hline & Göteborg & & $0.27 !$ \\
\hline & Sundsvall & & -0.24 \\
\hline & Constant & $-1.86^{* * *}$ & $-56.83^{* * *}$ \\
\hline & $\mathrm{N}$ & 7408 & 6965 \\
\hline & Nagelkerke's $\mathrm{R}^{2}$ & 49.5 & 53.5 \\
\hline & $\mathrm{BIC}^{\prime}$ & -4672.836 & -4616.974 \\
\hline
\end{tabular}

Notes: ***: significant at .001- level, ${ }^{* *}$ : significant at 0.01 -level, ${ }^{*}$ : significant at 0.05 -level, !: significant at 0.1 -level. Reference category for party choice: SAP. Other parties not shown. 
Table A4.2 Effects of voter group membership and attitudes towards lower unemployment benefits on party choice in Swedish Riksdag Election 2002. Coefficients from multinomial logistic regression models

\begin{tabular}{|c|c|c|}
\hline Party Choice & Variable & Model without controls \\
\hline \multirow[t]{4}{*}{$\begin{array}{l}\text { Left Party } \\
\text { (Vänsterpartiet) }\end{array}$} & $\begin{array}{l}\text { Voter group (Reference: non-core } \\
\text { constituency) }\end{array}$ & \\
\hline & Non-aligned core constituency & 0.12 \\
\hline & Lower unemployment benefits: no & $0.75^{* *}$ \\
\hline & Constant & $-2.33^{* * *}$ \\
\hline \multirow[t]{4}{*}{$\begin{array}{l}\text { Conservatives } \\
\text { (Moderaterna) }\end{array}$} & $\begin{array}{l}\text { Voter group (Reference: non-core } \\
\text { constituency) }\end{array}$ & \\
\hline & Non-aligned core constituency & $-1.16^{* * *}$ \\
\hline & Lower unemployment benefits: no & $-1.65^{* * *}$ \\
\hline & Constant & 0.09 \\
\hline \multirow[t]{4}{*}{ Centre Party } & $\begin{array}{l}\text { Voter group (Reference: non-core } \\
\text { constituency) }\end{array}$ & \\
\hline & Non-aligned core constituency & -0.24 \\
\hline & Lower unemployment benefits: no & $-0.65^{*}$ \\
\hline & Constant & $-1.49^{* * *}$ \\
\hline \multirow[t]{4}{*}{$\begin{array}{l}\text { Liberals } \\
\text { (Folkpartiet) }\end{array}$} & $\begin{array}{l}\text { Voter group (Reference: non-core } \\
\text { constituency) }\end{array}$ & \\
\hline & Non-aligned core constituency & $-0.73^{* * *}$ \\
\hline & Lower unemployment benefits: no & $-0.88^{* * *}$ \\
\hline & Constant & 0.13 \\
\hline \multirow[t]{4}{*}{ Christian Democrats } & $\begin{array}{l}\text { Voter group (Reference: non-core } \\
\text { constituency) }\end{array}$ & \\
\hline & Non-aligned core constituency & $-0.99 * *$ \\
\hline & Lower unemployment benefits: no & $-1.31^{* * *}$ \\
\hline & Constant & $0.97^{* * *}$ \\
\hline \multirow[t]{7}{*}{ Greens } & $\begin{array}{l}\text { Voter group (Reference: non-core } \\
\text { constituency) }\end{array}$ & \\
\hline & Non-aligned core constituency & -0.22 \\
\hline & Lower unemployment benefits: no & $0.54 !$ \\
\hline & Constant & $-2.72^{* * *}$ \\
\hline & $\mathrm{N}$ & 1271 \\
\hline & Nagelkerke's $\mathrm{R}^{2}$ & 15.5 \\
\hline & $\mathrm{BIC}^{\prime}$ & -79.83 \\
\hline
\end{tabular}

Note: ${ }^{* * *}$ : significant at .001- level, ${ }^{* *}$ significant at 0.01-level, ${ }^{*}$ significant at 0.05-level, !significant at 0.1-level Reference category for party choice: SAP. Other parties not shown. 



\section{Notes}

\section{Introduction}

1 I will use the label 'Third Way' for those social democratic parties that underwent a transformation during the last two or three decades, even though not all parties used such a label explicitly (Green-Pedersen et al. 2001).

\section{Theoretical Background}

1 I do not consider countries with compulsory voting, such as Australia or Belgium, where the electoral effects may follow their own logic.

2 See Giger (2011: chap. 2 and 3) for an excellent and thorough discussion on how arguments from the welfare state literature, the partisan politics literature, and various theories of issue voting and issue competition can be conceptualised into a framework for the study of the electoral consequences of welfare state reform and retrenchment.

3 I treat the DVU and NPD as separate parties in this book, although there have been recent efforts to merge the two parties.

4 Stöss (2006: 557) explicitly argues that: 'Conversely right-wing extremist parties have virtually no chances of success, if they directly follow the tradition of fascist and authoritarian regimes, especially if those regimes have been part of a country's own history [...]' (Own translation, CA).

5 Evans and Tilley's recent study (2012) argued and empirically demonstrated that the decline of class-party associations in Britain has been the consequence of Labour's move to the centre ground since the mid-1990s, and not the consequence of social change. Their case study thus provides evidence for a policy-based explanation of changing class voting, as advanced in this book. 
1 Ideally one would select a country in which a social democratic party in office had pursued no or almost no reforms during the period under review, but this was not the case in any advanced Western nation.

2 Starke (2008: 201) maintains that there is no 'clear causal relationship between retrenchment events and the structure of entitlements'.

3 There are some ambiguous cases, such as Ireland or France.

4 Lindbom (2001: 175) has claimed that replacement rates are the main ingredient of decommodification.

5 For further information, see the respective OECD publications.

6 Formerly called 'Benefit systems and work incentives'.

7 The coefficients and some model-fit statistics of each model used are reported in Appendices A-D. Given the parsimonious operationalisation of the core constituency concept and the restriction to a limited number of independent variables, these statistics indicate a good model-fit. All Nagelkerke Pseudo- $\mathrm{R}^{2}$-values exceed at least 15 per cent explained variance and all BIC-values are highly negative, indicating a superior fit compared to the null model or models with a high number of control variables.

8 This means that non-voting is always modelled as a category of the dependent variable if applicable.

\section{$4 \quad$ United Kingdom}

1 The results in Evans \& Norris (1999: Table 5.1) indicate that class generally had a remarkable degree of discriminating power for electoral behaviour in Britain, as almost each class stuck to a particular party in the period between 1964 and 1992.

2 Heath et al. (2001: 91ff) state that this allowed the SDP to win a considerable share of votes among the moderate centre-left, including working class votes, to the disadvantage of Labour.

3 Cf. Bara \& Budge (2001) and Webb (2003) for the ideological and strategic positioning of the Liberal Democrats after 1997.

$4 \quad$ Norris \& Wlezien (2005: 663) state that the Tories tried to mobilise their own voter base, but not traditional Labour voters or constituencies.

5 I do not consider regional parties here, as they only contest elections in constituencies in Northern Ireland, Scotland or Wales.

6 This aspect will be further discussed in the chapter's conclusion.

7 The variables used are presented and described in Appendix A. 
8 Due to their very low number of observations in the data sets, it was not possible to examine the results for small parties on the margins (e.g. Respect, UKIP or BNP) separately.

9 This was obtained by the vote recall item in the 2001 BEs. A similar procedure was used for the 2005 election.

10 An indirect effect can be observed here, however. If only party shares without non-voting are calculated, the share of the Liberal Democrats among Labour's voter base increases from about 15 per cent in 1997 to 20 per cent in 2005. Likewise, the share of minor parties in this voter group rose from 5 to 9 per cent in this period. This will be further addressed below.

11 The coefficients of the models can be found in Appendix A.

12 Unfortunately, the 2005 dataset does not contain the vote recall question for the 1997 election, which would allow us to generate a panel for the elections 1997 to 2005 .

13 Moreover, the BNP got parliamentary representation with the election to the European Parliament in 2009, held under list PR. It also entered several local councils, especially councils that had previously been dominated by Labour (Ford 2010; Ford \& Goodwin 2010: 21).

\section{Germany}

1 New Labour was a role model for the SPD in its quest to regain office after 16 years of Christian democratic rule. This culminated in the publication of the Schröder/Blair paper in 1999, which laid out some proposals on the transformation of European social democracy.

2 One exception was the 1989 pension reform (effective in 1992), which was passed not only with the support of the governmental majority (CDU, CSU and FDP), but also with that of the social democrats (cf. Schmidt 2006: 144).

3 I will use the label PDS to refer to the party before the merger with the WASG in 2005, and will use the label Left Party (Linkspartei) to refer to the party after this. This is to aid clarity, since the party had various temporary labels after the unification, such as 'SED-PDS', PDS-Linke Listen' and 'Linkspartei.PDs'. It also used the label 'Die Linke' (The Left) after the 2005 election.

4 The 1970 and the 1980 os in particular were characterised by remarkable polarisation on non-economic issues such as the 'Neue Ostpolitik' in 1970s, the fierce debate about the 'NATO Double-Track Decision' beginning in the late 1970 , and the discussion about nuclear power in Germany. 
This can be demonstrated by separating party choice and class by region (results not shown). The support for the PDS among those classes in Western Germany was almost non-existent until 2005.

6 The party never gained much more than 1 per cent in the Western part of Germany (Picot 2009: 169; www.Bundeswahlleiter.de).

7 The pension scheme was named after the then Minister of Labour and Social Affairs, Walter Riester.

8 The Riester reform was accompanied by the introduction of a means-tested minimum pension.

9 Egle \& Henkes (2003) claim that the first term nevertheless set the stage for future policy changes, as the SPD's internal balances of powers shifted towards 'the modernisers', away from 'the traditionalists'.

10 With the Hartz III reform, the name changed to 'Bundesagentur für Arbeit'.

11 In this vein, the Hartz IV reform is an illustrative example of Huo's argument about a paradigm shift towards prioritarian egalitarianism, as the core work force was no longer the target group of the new ALG II, but various groups of labour market outsiders who had often claimed Sozialhilfe in the past. The political debate on the reform often focused on an equity conflict, as workers with long contribution records could lose a large share of their former income, whereas labour market outsiders could now claim (almost) the same benefits as people with long contribution records.

12 There were exceptions for the unemployed older than 54 with eligibility periods up to 18 months.

13 In 1998, the PDS gained 5.1 per cent of the vote, barely passing the 5 per cent threshold. The party gained parliamentary representation in 1994 by winning more than two constituencies in Eastern Germany (the so-called 'Grundmandateklausel'). In 1990, the party benefited from the separate application of the 5 per cent threshold for both parts of Germany as the party only passed the threshold in the new Länder (like the Greens).

14 This can, of course, be seen as a blame-avoidance strategy in a Piersonian sense.

15 Picot (2009) claims that the SPD was encouraged to reform due to the lack of left-wing opposition, but underestimated the risk of the rise of the PDS or another left competitor and thus ignored the possibility of changes in party competition. In this respect, the lack of serious reforms and the German electorate's welfare bias (Padgett 2004, 2005) should account for the failure to establish a left socialist party at the federal level until 2002.

16 One motivation for Gerhard Schröder to call early elections was that the election would explicitly be a referendum on his reform agenda (cf. Zohlnhöfer \& Egle 2007; Kornelius \& Roth 2007: 36; Jesse 2006: 23 for discussions of this motivation). 
17 The NPD and DVU launched some protest campaigns against the Hartz reforms, but were only able to pass the 5 per cent threshold in two eastern states in 2004 (see Jesse 2005; Niedermayer 2005).

18 All items used and the coefficients of the logistic regression models can be found in Appendix B.

19 The distribution of the party shares in the 2002 and 2005 election studies diverges considerably from the actual results, which may explain the figures reported in Table 5.6.

20 It is worth mentioning that the Left Party/PDS also gained many votes after the reforms in all but two state elections, namely Mecklenburg-West Pomerania and Berlin, where the party was in coalition with the SPD and had to implement the labour market reforms and engage in retrenchment. Here, the party lost in the state elections, going against the national trend and supporting the claim that 'dirty hands' make a difference (cf. Werz \& Schoon 2007 and Niedermayer \& Stöss 2007 for analyses of these two elections).

21 In this respect, future analysis should tap into the problem of whether the first period of red-green government was a transition period in which the SPD already alienated parts of its core constituency, which later became available to the Left Party after it emerged on the national scene. This means that there was not only a direct but also an indirect realignment in this period, as some dissatisfied social democratic core voters broke with their party in Schröder's first electoral term, but had no party to align with until 2005 (see Picot 2009).

\section{Denmark}

1 This section draws heavily on Petersen's analysis (2001) of the Danish social democratic party's ideology and welfare policy in party manifestos and party constitutions after 1945 .

2 The 1977 constitution also stipulates that the eligibility period for unemployment benefits should be unlimited.

3 Nineteen members of the party's parliamentary group abstained in the final vote on the reform of the health system, however.

4 See also the respective sections in Petersen (1998) matching the programmatic positions of the parties with their actual behaviour in daily politics, especially in the legislative procedures concerning the development of the Danish welfare state.

5 This does not exclude other parties, including parties of the centre-right, from occasionally supporting the expansion of the welfare state and also im- 
plementing universality principles in the Danish welfare state when in government.

6 Parts of the labour market reform came into force in 1994, however.

7 The SD won some votes in this election (see above), but the Centre-Democrats had stepped out of the government in 1996.

8 Similarly, the social democratic government reformed the disability pension scheme (Førtidspensionen) in 2000 by tightening the eligibility criteria to increase the labour supply (Green-Pedersen 2002b: $71 \mathrm{f}$ ).

9 The data in Scruggs' study (2007) also point to a reduction in replacement rates under the social democrats, since both the single and the family replacement rates declined by 9 percentage points from 1990-2002.

10 The Red-Green Alliance emerged as a fusion of various far-left splinter parties after 1988.

11 I do not focus on the Red-Green Alliance here, as all arguments apply equally or even more so to this party. Moreover, due to the party's far left stance at that time, it was not electable in the view of a large part of the Danish electorate.

12 This is especially true for the period under consideration, given the decline of the centre parties in the 1990 .

13 Klitgaard (2002: 197) states that the SF was against the first labour market reform package in 1993, when the SD governed as a majority government and the socialists were not part of the SD's parliamentary base.

14 The exact wording of the items can be found Appendix $C$.

15 The coefficients of the model can be found in Appendix C. Another model with immigration as control was also run. As there are no fundamental differences between the parties' results, I only report important differences caused by immigration in the text.

16 The group of 'other parties' also gained more votes compared to the left-hand side of the panel. The Conservatives in particular make some gains if these conditions apply.

17 The results also suggest that the 2001 election was not only a deviating election, as claimed by Qvortrup (2002), but a critical election due to the lasting realignment of voter groups to the DF and the Liberals (see Borre 2003 for a more critical assessment).

18 One may speculate whether the party appears as a functional equivalent to Western European Christian democratic parties after its ideological transformation into a cross-class party. 


\section{Sweden}

1 The SAP typically governed as a minority government with changing partners in legislation. However, between 1951 and 1957 it formed a coalition with the Agrarian Union (renamed the Centre Party in 1957) and in the period between 1968 and 1971, the SAP governed with an absolute majority.

2 A coalition of the Centre Party, the Liberals and the Moderates led by the Centre Party governed Sweden from 1976-78, followed by a minority government of the liberal Folkparti in 1978-79. After the 1979 election, the Centre Party again led a coalition with the Liberals and the Moderates until 1981, when the latter stepped out and the remaining two parties continued as a minority government until the 1982 election (Arter 1999a: Table 8.2).

3 See Olsson (1990: 225) for a schematic overview of the austerity measures of the early 1980 .

4 Esping-Andersen also identifies this reform as a major reason for the SAP's outstanding electoral performance in the 1960.

5 In addition, the effects of the changed indexation rules are more difficult to detect and their effects will become evident in the long run. The symbolic raising of maximum amounts also obfuscates this type of austerity measure (Christiansen et al. 2010; cf. also Timonen 2003: 98).

6 Other welfare schemes were affected by temporary cutbacks between 1995 and 1997, but reversed with the 1997 budget (Timonen 2003: 96; Starke 2008: 172).

7 Palme et al. (2002) nevertheless report that this was not accompanied by an increase in the number of people not eligible for any kind of unemployment benefits, but that the respective figures decreased. This indicates that these measures did not have far-reaching effects, as the number of persons concerned can be expected to be rather limited.

8 This section on the pension reform draws on the works of Palme \& Wennemo (1998) and Anderson \& Meyer (2004).

9 Waiting days had been discussed under previous SAP administrations during the 1970s and 1980s (cf. Lindbom 2001: 178).

10 In Germany, the corresponding period was already one year in the 1980 s. The Danish social democrats introduced a qualification period of one year of employed work in 1996. In comparison, the SAP's reform of the qualification period is very modest.

11 The pension reform can be regarded as a big-bang reform, but without outright retrenchment or recommodification as discussed above.

12 According to Huo (2009: 208) there was much more progress in reforming social assistance than unemployment insurance. 
13 The party changed its name from Kristdemokratiska Samhällspartiet to Kristdemokraterna in 1996.

14 The Sweden Democrats surpassed the threshold in the 2010 Riksdag election, which is discussed in section 7.7 below.

15 Originally, the party's name was Sweden's Communist Party (Sveriges Kommunistiska Parti, SKP) but in 1967 the name was changed to the Left Party Communists (Vänsterpartiet Kommunisterna, vPK).

\section{Comparative Summary}

1 Evans and Tilley's recent study on class-based party affiliations found a similar pattern in Britain since 1990. The increase of voters with no party identification is strongest among the working class.

2 As outlined in Chapter 5, the party seems to benefit more indirectly through the abstention of former Labour voters and always had some working class support as the successor party to the SDP.

3 I will focus on the SF, as similar arguments apply to the small and far-left RedGreen Alliance and the party did not make significant gains during the period under investigation.

4 The Progress Party did not make gains among social democratic core voters in the 1980 os when the immigration and refugee issue emerged on the political agenda, which confirms the importance of the welfare dimension.

5 See Evans \& Tilley (2012) for a similar conclusion in their study of the effect of Labour's ideological change on class voting in Britain in recent decades.

6 In Germany, the SPD's coalition partner changed in 2005 from the Greens to the CDU/CSU for the electoral term 2005-09.

\section{Discussion}

1 The name is written as one word, in contrast to the British 'New Labour'.

2 Analysing the case of Australia would be a really strong test of the claim that majoritarian electoral systems produce lower turnout of social democratic core voters. Like New Zealand, Australia experienced welfare state reforms and has a quasi majoritarian system for the House of Representatives, but also compulsory voting. Under such conditions, reform-averse social democratic voters might have no other viable option than to stick to the party, as the opponents of the Australian Labor Party are two market liberal parties. 
3 Like the Swedish SAP, the DNA also advocated ALMPS and notions of mild workfare from early on.

4 I owe thanks to Patrick Emmenegger for making this instructive example at the workshop on 'Political Parties and Welfare State Reform', 18 January 2011 held at Aarhus University. 



\section{References}

Aardal, Bernt \& van Wijnen, Pieter (2005): Issue Voting. In: Thomassen, Jacques (ed.): The European Voter. Oxford, Oxford University Press. pp. 192-212.

Achterberg, Peter (2006): Class Voting in the New Political Culture. Economic, Cultural and Environmental Voting in 20 Western Countries, in: International Sociology 21(2), pp. 237-261.

Adams, James F., Merrill III, Samuel \& Grofman, Bernard (2005): A Unified Theory of Party Competition. A Cross-National Analysis Integrating Spatial and Behavioral Factors. Cambridge, Cambridge University Press.

Agius, Christine (2007): Sweden's 2006 Parliamentary Election and After: Contesting or Consolidating the Swedish Model?, in: Parliamentary Affairs 6o(4), pp. 585-60o.

Ai, Chunrong \& Norton, Edward C. (2003): Interaction Terms in Logit and Probit Models, in: Economics Letters 8o, pp. 123-129.

Allen, Christopher S. (2009): Empty Nets. Social Democracy and the 'Catch-All Party Thesis' in Germany and Sweden, in: Party Politics 15(5), pp. 635-653.

Allen, James P. \& Scruggs, Lyle (2004): Political Partisanship and Welfare State Reform in Advanced Industrial Societies, in: American Journal of Political Science 48(3), pp. 496-512.

Åmark, Klas (2005): Hundra År av Välfärdspolitik. Välfärdsstatens Framväxt $i$ Norge og Sverige. Umeå, Boréå.

Andersen, Johannes, Borre, Ole, Goul Andersen, Jørgen \& Nielsen, Hans Jørgen [eds.] (1999): Valgerne med Omtanke. En Analyse af Folketingsvalget 1998. Aarhus, Systime.

Anderson, Karen M. \& Meyer, Traute (2004): The Third Way in Welfare State Reform? Social Democratic Pension Politics in Germany and Sweden. In: Bonoli, Guiliano \& Powell, Martin (eds.): Social Democratic Party Policies in Contemporary Europe. London \& New York, Routledge. pp. 141-160. 
Annesley, Claire \& Gamble, Andrew (2004): Economic and Welfare Policy. In: Ludlam, Steve \& Smith, Martin J. (eds.): Governing as New Labour: Policy and Politics under Blair. Houndmills, Palgrave Macmillan. pp. 144-160.

Armingeon, Klaus (2006): Reconciling Competing Claims of the Welfare State Clientele: The Politics of Old and New Social Risk Coverage in Comparative Perspective. In: Armingeon, Klaus \& Bonoli, Giuliano (eds.): The Politics of Post-Industrial Welfare States. Adapting Postwar Social Policies to New Social Risks. London \& New York, Routledge. pp. 100-122.

Armingeon, Klaus \& Bonoli, Giuliano [eds.] (2006): The Politics of PostIndustrial Welfare States. Adapting Post-war Social Policies to New Social Risks. London \& New York, Routledge.

Armingeon, Klaus \& Giger, Nathalie (2008): Conditional Punishment: A Comparative Analysis of the Electoral Consequences of Welfare State Retrenchment, in: West European Politics 31(3), pp. 558-58o.

Arndt, Christoph (2012): Social Democracy's Mobilization of New Constituencies: The Role of Electoral Systems. Forthcoming in Party Politics. doi: $10.1177 / 1354068812453372$.

Arter, David (1999a): Sweden: A Mild Case of 'Electoral Instability Syndrom'? In: Broughton, David \& Donovan, Mark (eds.): Changing Party Systems in Western Europe. London \& New York, Pinter. pp. 143-162.

Arter, David (1999b): Party System Change in Scandinavia since 1970: 'Restricted Change' or 'General Change'?, in: West European Politics 22(3), pp. 139-158.

Arter, David (2002): 'Communists we are no longer, Social Democrats we can never be': The Evolution of the Leftist Parties in Finland and Sweden, in: Journal of Communist Studies and Transition Politics, 18(3), pp. 1-28.

Arter, David (2003): Scandinavia: What's Left is the Social Democratic Welfare Consensus, in: Parliamentary Affairs 56(1), pp. 75-98.

Arzheimer, Kai \& Carter, Elisabeth (2006): Political Opportunity Structures and Right-Wing Extremist Party Success, in: European Journal of Political Research 45(3), pp. 419-443.

Baldwin, Peter (1990): The Politics of Social Security: Class Bases of the European Welfare States 1875-1975. Cambridge, Cambridge University Press. Bara, Judith \& Budge, Ian (2001): Party Policy and Ideology: Still New Labour? In: Norris, Pippa (ed.): Britain Votes 2001. Oxford, Oxford University Press. pp. 26-42. 
Bartolini, Stefano (2007): The Political Mobilization of the European Left, 1860-1980. The Class Cleavage. Cambridge, Cambridge University Press.

Bergh, Andreas \& Erlingsson, Gissur Ó. (2009): Liberalization without Retrenchment: Understanding the Consensus on Swedish Welfare State Reforms, in: Scandinavian Political Studies, 32(1), pp. 71-92.

Bergqvist, Christina \& Lindbom, Anders (2003): The Swedish Welfare State: Neo-liberal Challenge and Welfare State Resilience, in: Österreichische Zeitschrift für Politikwissenschaft 32(4), pp. 389-401.

Berry, William D., DeMeritt, Jacqueline H.R. \& Esarey, Justin (2010): Testing for Interaction in Binary Logit and Probit Models: Is a Product Terms Essential?, in: American Journal of Political Science 54(1), pp. 248-266.

Bille, Lars (1999): Denmark, in: European Journal of Political Research 36(3/4), pp. 371-381.

Blair, Tony \& Schröder, Gerhard (1999): Europe: The Third Way/die Neue Mitte. In: Hombach, Bodo (ed.): The Politics of the New Centre. Cambridge, Polity Press. pp. 157-177.

Blancke, Susanne \& Schmid, Josef (2003): Bilanz der Bundesregierung Schröder in der Arbeitsmarktpolitik 1998-2002: Ansätze zu einer doppelten Wende. In: Egle, Christoph, Ostheim, Tobias \& Zohlnhöfer, Reimut (eds.): Das Rot-grüne Projekt. Eine Bilanz der Regierung Schröder 1998-2002. Wiesbaden, Westdeutscher Verlag. pp. 215-238.

Blätte, Andreas (2010): Reduzierter Parteienwettbewerb durch kalkulierte Demobilisierung. Bestimmungsgründe des Wahlkampfverhaltens im Bundestagswahlkampf 2009. In: Korte, Karl-Rudolf (ed.): Die Bundestagswahl 2009. Analysen der Wahl-, Parteien-, Kommunikations- und Regierungsforschung. Wiesbaden, VS-Verlag, pp. 273-297.

Blomqvist, Paula \& Green-Pedersen, Christoffer (2004): Defeat at Home? Issue-Ownership and Social Democratic Support in Scandinavia, in: Government and Opposition 39(4). pp. 587-613.

Boeri, Tito, Börsch-Supan, Axel \& Tabellini, Guido (2001): Would You Like to Shrink the Welfare State? A Survey of European Citizens, in: Economic Policy 32, pp. 9-50.

Bonoli, Guiliano (2001): Political Institutions, Veto Points, and the Process of Welfare State Adaption. In: Pierson, Paul (ed.): The New Politics of the Welfare State. Oxford, Oxford University Press. pp. 238264.

Bonoli, Guiliano (2004): Social Democratic Party Policies in Europe. Towards a Third Way? In: Bonoli, Guiliano \& Powell, Martin (eds.): So- 
cial Democratic Party Policies in Contemporary Europe. London \& New York, Routledge. pp. 197-213.

Bonoli, Guiliano \& Powell, Martin [eds.] (2004): Social Democratic Party Policies in Contemporary Europe. London \& New York, Routledge.

Borre, Ole (2003): Et Kritisk Valg? In: Goul Andersen, Jørgen \& Borre, Ole (eds.): Politisk Forandring. Vardipolitik og Nye Skillelinjer ved Folketingsvalget 2001. Aarhus, Systime. pp. 75-86.

Breen, Richard (1997): Risk, Recommodification and Stratification, in: Sociology 31(3), pp. 473-489.

Brooks, Clem, Nieuwbeerta, Paul \& Manza, Jeff (2006): Cleavage-based Voting Behaviour in Cross-national Perspective: Evidence from Six Postwar Democracies; in: Social Science Research 35(1), pp. 88-128.

Budge, Ian \& Farlie, Dennis (1983): Party Competition - Selective Emphasis or Direct Confrontation? In: Daalder, Hans \& Mair, Peter (eds.): Western European Party Systems. London, Sage. pp. 267-305.

Bundeswahlleiter.de (various years and reports): accessed at: www. bundeswahlleiter.de.

Busemeyer, Marius R. (2009): Social Democrats and the New Partisan Politics of Public Investment in Education, in: Journal of European Public Policy 16(1), pp. 107-126.

Butler, David \& Stokes, Donald (1974): Political Change in Britain. The Evolution of Electoral Choice. Second Edition. London \& Basingstoke, Macmillan.

Butler, David \& Kavanagh, Dennis (2002): The British General Election of 2001. Houndmills, Palgrave.

Camerra-Rowe, Pamela (2004): Agenda 2010. Redefining German Social Democracy, in: German Politics and Society 22(1), pp. 1-30.

Carter, Elizabeth (2005): The Extreme Right in Western Europe. Manchester, Manchester University Press.

Castles, Francis G. (1978): The Social Democratic Image of Society: A Study of the Achievement and Origins of Scandinavian Social Democracy in Comparative Perspective. London, Routledge and Kegan Poul.

Christiansen, Niels Finn (1994): Denmark: End of an Idyll? In: Anderson, Perry \& Camiller, Patrick (eds.): Mapping the West European Left. London, Verso. pp. 77-101.

Christiansen, Flemming Juul (2008): Politiske Forlig i Folketinget. Partikonkurrence og Samarbejde. Aarhus, Politica.

Christiansen, Flemming Juul, Green-Pedersen, Christoffer \& Jensen, Carsten (2010): Dismantling Strategies in a Comparative Perspective. Manuscript, Department of Political Science, Aarhus University. 
Christensen, Jacob (1998): Socialpolitiske Strategier 1945-1972. Odense, Odense Universitetsforlag.

Clasen, Jochen (2002): Modern Social Democracy and European Welfare State Reform, in: Social Policy \& Society 1(1), pp. 67-76.

Clasen, Jochen (2005): Reforming European Welfare States. Germany and the United Kingdom Compared. Oxford, Oxford University Press.

Clasen, Jochen \& Clegg, Daniel (2007): Levels and Levers of Conditionality: Measuring Change within Welfare States. In: Clasen, Jochen \& Siegel, Nico A. (eds.): Investigating Welfare State Change. The 'Dependent Variable Problem' in Comparative Analysis. Cheltenham, Edward Elgar. pp. 166-197.

Clasen, Jochen \& Siegel, Nico A. [eds.] (2007): Investigating Welfare State Change. The 'Dependent Variable Problem' in Comparative Analysis. Cheltenham, Edward Elgar.

Cox, Robert H. (2001): The Social Construction of an Imperative: Why Welfare Reform Happened in Denmark and the Netherlands but Not in Germany, in: World Politics 53(3), pp. 463-498.

Cressey, Peter (1999): New Labour and Employment, Training and Employee Relations. In: Powell, Martin (ed.): New Labour, New Welfare State? Bristol, Policy Press. pp. 171-19o.

Crosland, C.A.R (1956): The Future of Socialism. London, Cape.

Cuperus, René \& Kandel, Johannes [eds.] (1998): European Social Democracy: Transformation in Progress. Amsterdam, Wiardi Beckman Stichting \& Friedrich Ebert Stiftung.

Cuperus, René, Duffek, Karl \& Kandel, Johannes [eds.] (2001): Multiple Third Ways. European Social Democracy facing the Twin Revolution of Globalisation and the Knowledge Society. Amsterdam, Berlin \& Vienna, Bevrijding.

Dagens Nyheter (2010): De är Chanslösa mot Reinfeldt, in: Dagens $N y$ heter, 1 April, 2010.

Dahl, Espen \& Drøpping, Jon Anders (2001): The Norwegian Work Approach in the 1990s: Rhetoric and Reform. In: Gilbert, Neil \& Van Voorhis, Rebecca A. (eds.): Activating the Unemployed: A Comparative Appraisal of Work-Oriented Policies. New Brunswick \& London, Transaction Publishers. pp. 267-292.

Dalton, Russell J. (1984): Cognitive Mobilization and Partisan Dealignment in Advanced Industrial Democracies, in: Journal of Politics 46(1), pp. 264-284.

Dalton, Russell J. (1996): Citizen Politics in Western Democracies. 2nd Edition. Chatham, Chatham House Publishers. 
Dalton, Russell J. \& Bürklin, Wilhelm (1995): The Two German Electorates: The Social Bases of the Vote in 1990 and 1994, in: German Politics and Society 13(1), pp. 75-99.

Damgaard, Erik (2003): Denmark: The Life and Death of Government Coalitions. In: Müller, Wolfgang C. \& Strøm, Kaare (eds.): Coalition Governments in Western Europe. pp. 231-263.

Debus, Marc (2008): Unfulfilled Promises? German Social Democrats and their Policy Positions at the Federal and State Level between 1994 and 2006, in: Journal of Elections, Public Opinion and Parties 18(2), pp. 201-224.

De Graaf, Nan Dirk, Nieuwbeerta, Paul \& Heath, Anthony (1995): Class Mobility and Political Preferences: Individual and Context Effects, in: American Journal of Sociology 100(4), pp. 997-1027.

Denver, David \& Fisher, Justin (2009): Blair's Electoral Record. In: Casey, Terrence (ed.): The Blair Legacy. Politics, Policy, Governance, and Foreign Affairs. Basingstoke \& New York, Macmillan. pp. 23-38.

Der Spiegel (2005): PDS heißt jetzt Linkspartei, in: Der Spiegel, July 17, 2005.

Dingeldey, Irene (2007): Between Workfare and Enablement - The Different Paths to Transformation of the Welfare State: A Comparative Analysis of Activating Labour Market Policies, in: European Journal of Political Research 46(6), pp. 823-851.

Dolezal, Martin (2008): Germany: the Dog that Didn't Bark. In: Kriesi, Hanspeter et al. (eds.), European Politics in the Age of Globalization. Cambridge, Cambridge University Press. pp. 208-233.

Dümig, Kathrin (2010): Ruhe nach und vor dem Sturm: Die Arbeitsmarktund Beschäftigungspolitik der Großen Koalition. In: Egle, Christoph \& Zohlnhöfer, Reimut (eds.): Die zweite Große Koalition. Eine Bilanz der Regierung Merkel 2005-2009. Wiesbaden, VS Verlag. pp. 279-301.

Dunleavy, Patrick (1980): The Political Implications of Sectoral Cleavages and the Growth of State Employment, in: Political Studies 28(3), pp. 364-383 (part I) and 28(4), pp. 527-549 (part II).

Dunleavy, Patrick (2005): Facing Up to Multi-Party Politics: How Partisan Dealignment and PR Voting Have Fundamentally Changed Britain's Party Systems, in: Parliamentary Affairs 58(3), pp. 503-532.

Dunleavy, Patrick \& Margetts, Helen (2005): The Impact of UK Electoral Systems, in: Parliamentary Affairs 58(4), pp. 854-870.

Dwyer, Peter (2004): Creeping Conditionality in the UK: From Welfare Rights to Conditional Entitlements?, in: Canadian Journal of Sociology 29(2), pp. 265-287. 
Edlund, Jonas (2007): Class Conflicts and Institutional Feedback Effects in Liberal and Social Democratic Welfare Regimes. Attitudes towards State Redistribution and Welfare Policy in Six Western Countries. In: Svallfors, Stefan (ed.): The Political Sociology of the Welfare State. Institutions, Social Cleavages, and Orientations. Stanford, Stanford University Press. pp. 30-79.

Egle, Christoph \& Henkes, Christian (2003): Später Sieg der Modernisierer über die Traditionalisten? Die Programmdebatte in der SPD. In: Egle, Christoph, Ostheim, Tobias \& Zohlnhöfer, Reimut (eds.): Das Rot-grüne Projekt. Eine Bilanz der Regierung Schröder 1998-2002. Wiesbaden, Westdeutscher Verlag. pp. 67-92.

Egle, Christoph (2010): Im Schatten der Linkspartei. Die Entwicklung des Parteienwettbewerbs während der 16. Legislaturperiode. In: Egle, Christoph \& Zohlnhöfer, Reimut (eds.): Die zweite Große Koalition. Eine Bilanz der Regierung Merkel 2005-2009. Wiesbaden, VS Verlag. pp. 99-122.

Elff, Martin (2010): Disenchanted Workers, Selective Abstention and the Electoral Defeat of Social Democracy in Germany. Paper presented at the 106th Annual meeting of the American Political Science Association, 2-5 September, Washington, DC.

Elklit, Jørgen, Møller, Birgit, Svensson, Palle \& Togeby, Lise (2005): Gensyn med Sofavalgerne. Valgdeltagelse i Danmark. Aarhus, Aarhus Universitetsforlag.

Ellison, Nick (1997): From Welfare State to Post-Welfare Society? Labour's Social Policy in Historical and Contemporary Perspective. In: Brivati, Brian \& Bale, Tim (eds.): New Labour in Power: Precedents and Prospects. Routledge, London \& New York. pp. 34-61.

Erikson, Robert \& Goldthorpe, John H. (1992): The Constant Flux: A Study of Class Mobility in Industrial Societies. Oxford, Oxford University Press.

Esping-Andersen, Gøsta (1985): Politics against Markets. Princeton, Princeton University Press.

Esping-Andersen, Gøsta (1990): The Three Worlds of Welfare Capitalism. Cambridge, Polity Press.

Esping-Andersen, Gøsta (1999): Social Foundations of Postindustrial Economies. Oxford, Oxford University Press.

Esping-Andersen, Gøsta \& Korpi, Walter (1987): From Poor Relief to Institutional Welfare States: The Development of Scandinavian Social Policy. In: Erikson, Robert, Hansen, Erik Jørgen, Ringen, Stein \& Uusitalo, Hannu (eds.): The Scandinavian Model. Welfare States and Welfare Research. New York, M.E. Sharpe, Inc. pp. 39-74. 
Evans, Geoffrey (1999): The End of Class Politics? Oxford, Oxford University Press.

Evans, Geoffrey (200o): The Continued Significance of Class Voting, in: Annual Review of Political Science 3, pp. 401-417.

Evans, Geoffrey \& Norris, Pippa (1999): Critical Elections. British Parties and Voters in Long-term Perspective. Sage, London.

Evans, Geoffrey \& Tilley, James (2012): How Parties Shape Class Politics: Explaining the Decline of the Class Basis of Party Support, in: British Journal of Political Science 42(1), pp. 137-161.

FAZ (2005): Linke Alternative zu den 'Hartz-IV-Parteien', in: Frankfurter Allgemeine Zeitung, 3 July, 2005.

Feist, Ursula \& Hoffmann, Hans-Jürgen (1999): Die Bundestagswahlanalyse 1998: Wahl des Wechsels, in: Zeitschrift für Parlamentsfragen 3o(2), pp. 215-251.

Feldt, Kjell-Olof (1985): Den Tredje Vägen. En Politik for Sverige. Borås, Tiden.

Fleckenstein, Timo (2008): Restructuring Welfare for the Unemployed: the Hartz Legislation in Germany, in: Journal of Social Policy 18(2), pp. 177-188.

Folketinget.dk: Valg og Tendenser, accessed at: http://www.ft.dk/Dokumenter/Publikationer/Tal\%20og\%20Fakta/Valg_og_tendenser.aspx

Ford, Robert (2010): Who Might Vote for the BNP?: Survey Evidence on the Electoral Potential of the Extreme Right in Britain. In: Eatwell, Roger \& Goodwin, Matthew J. (eds.): The New Extremism in 21st Century Britain. London \& New York, Routledge. pp. 145-168.

Ford, Robert \& Goodwin, Matthew J. (2010): Angry White Men: Individual and Contextual Predictors of Support for the British National Party, in: Political Studies 58(1), pp. 1-25.

Franklin, Mark N. (1985): The Decline in Class Voting in Britain: Changes in the Basis of Electoral Choice, 1964-1983. Oxford, Oxford University Press.

George, Alexander L. \& Bennett, Andrew (2005): Case Studies and Theory Development in the Social Sciences. Cambridge, MA \& London, MIT Press.

Gerring, John (2007): Case Study Research. Principles and Practices. New York, Cambridge University Press.

Giddens, Anthony (1998): The Third Way. The Renewal of Social Democracy. Cambridge, Polity Press. 
Giger, Nathalie (2011): The Risk of Social Policy? The Electoral Consequences of Welfare State Retrenchment and Social Policy Performance in OECD Countries. London \& New York, Routledge.

Giger, Nathalie \& Nelson, Moira (2011): The Electoral Consequences of Welfare State Retrenchment: Blame Avoidance or Credit Claiming in the Era of Permanent Austerity?, in: European Journal of Political Research 50(1), pp. 1-23.

Glennerster, Howard (2007): British Social Policy: 1945 to the Present. Third Edition. Malden, MA, Blackwell Publishing.

Goldthorpe, John H. (1996): Class and Politics in Advanced Industrial Societies. In: Lee, David, J. \& Turner, Bryan S. (eds.): Conflicts about Class. Debating Inequality in Late Industrialism. London, Longman. pp. 196-208.

Goldthorpe, John H. (2007): Social Class and the Differentiation of Employment Contracts, in: Goldthorpe, John, H.: On Sociology, Second Edition, Volume Two: Illustration and Retrospect. Stanford, Stanford University Press. pp. 101-123.

Goldthorpe, John H., Lockwood, David, Bechhoffer, Frank \& Platt, Jennifer (1968): The Affluent Worker: Political Attitudes and Behaviour. Cambridge, Cambridge University Press.

Goodwin, Matthew J. (2010): Activism in Contemporary Extreme Right Parties: The Case of the British National Party (BNP), in: Journal of Elections, Public Opinion E Parties 20(1), pp. 31-54.

Goodwin, Matthew J., Ford, Robert, Duffy, Bobby \& Robey, Rea (2010): Who Votes Extreme Right in Twenty-first-century Britain? The Social Bases of Support for the National Front and British National Party. In: Eatwell, Roger \& Goodwin, Matthew J. (eds.): The New Extremism in 21st Century Britain. London \& New York, Routledge. pp. 191-210.

Goul Andersen, Jørgen (2002): Work and Citizenship: Unemployment and Unemployment Policies in Denmark 1980-200o. In: Goul Andersen, Jørgen \& Jensen, Per H. (eds.): Changing Labour Markets, Welfare Policies and Citizenship. Bristol, Policy Press. pp. 59-84.

Goul Andersen, Jørgen (2003a): Operationen Lykkedes, Men Lægen Døde. Socialdemokratiets Kriser fra Krag til Lykketoft, in: Politica 35(4), pp. 413-432.

Goul Andersen, Jørgen (2003b): Farligt Farvand: Vælgernes Holdninger til Velfærdspolitik og Skatter. In: Goul Andersen, Jørgen \& Borre, Ole (eds.): Politisk Forandring. Verdipolitik og Nye Skillelinjer ved Folketingsvalget 2001. Aarhus, Systime. pp. 293-314.

Goul Andersen, Jørgen (2007): Samfundskonflikter, Partier i Bevægelse og Vælgere med Omtanke: Rids af en Generel Teoretisk Ramme. In: 
Goul Andersen, Jørgen, Andersen, Johannes, Borre, Ole, Hansen, Kasper Møller \& Nielsen, Hans Jørgen (eds.): Det Nye Politiske Landskab. Folketingsvalget 2005 i Perspektiv. Aarhus, Academica. pp. 11-55. Goul Andersen, Jørgen \& Borre, Ole (2003): Politisk Forandring. Vardipolitik og Nye Skillelinjer ved Folketingsvalget 2001. Aarhus, Systime.

Goul Andersen, Jørgen, Andersen, Johannes, Borre, Ole, Hansen, Kasper Møller \& Nielsen, Hans Jørgen [eds.] (2007): Det Nye Politiske Landskab. Folketingsvalget 2005 i Perspektiv. Aarhus, Academica.

Goul Andersen, Jørgen \& Carstensen, Martin B. (2009): The Welfare State and Welfare Reforms in Denmark. In: Golinowska, Stanislawa, Hengstenberg, Peter \& Zukowski, Maciej (eds.), Diversity and Commonality in European Social Politics: The Forging of a European Social Model, Warszawa: Friedrich Ebert Stiftung. pp. 70-109.

Green-Pedersen, Christoffer (2001): Minority Governments and Party Politics: The Political and Institutional Background to the 'Danish Miracle', in: Journal of Public Policy 21(1), pp. 53-70.

Green-Pedersen, Christoffer (2002a): The Politics of Justification. Party

Competition and Welfare-State Retrenchment in Denmark and the Netherlands from 1982 to 1998. Amsterdam, Amsterdam University Press.

Green-Pedersen, Christoffer (2002b): Den Danske Velfærdsstat fra Afgrundens Rand til Efterlønsreformen. En Oversigt, in: Politica 34(1), pp. 68-77.

Green-Pedersen, Christoffer (2004): The Dependent Variable Problem Within the Study of Welfare State Retrenchment: Defining the Problem and Looking for Solution, in: Journal of Comparative Policy Analysis 6(1), pp. 3-14.

Green-Pedersen, Christoffer \& Haverland, Markus (2002): The New Politics and Scholarship of the Welfare State, in: Journal of European Social Policy 12(1), pp. 43-51.

Green-Pedersen, Christoffer \& Krogstrup, Jesper (2008): Immigration as Political Issue in Denmark and Sweden, in: European Journal of Political Research 47(5), pp. 610-634.

Green-Pedersen, Christoffer \& van Kersbergen, Kees (2002): The Politics of the 'Third Way': the Transformation of Social Democracy in Denmark and the Netherlands, in: Party Politics 8(5), pp. 507-524.

Green-Pedersen, Christoffer, van Kersbergen, Kees \& Hemerijck, Anton (2001): Neo-liberalism, the 'Third Way' or What? Recent Social Democratic Welfare Policies in Denmark and the Netherlands, in: Journal of European Public Policy 8(2), pp. 307-325. 
Güveli, Ayse (2006): New Social Classes within the Service Class in the Netherlands and Britain. Unpublished Dissertation, Radbound University Nijmegen.

Harlen, Christine Margerum (2002): Schröder's Economic Reforms: The End of Reformstau?, in: German Politics 11(1), pp. 61-8o.

Häusermann, Silja (2006): Changing Coalitions in Social Policy Reforms: The Politics of New Social Needs and Demands, in: Journal of European Social Policy 16(1), pp. 5-21.

Häusermann, Silja (2010): The Politics of Welfare State Reform in Continental Europe. Modernization in Hard Times. New York, Cambridge University Press.

Heath, Anthony F., Curtice, John K., Jowell, Roger M., Evans, Geoffrey, Field, Julia \& Witherspoon, Sharon (1991): Understanding Political Change: The British Voter 1964-1987. Oxford, Pergamon.

Heath, Anthony F., Jowell, Roger M. \& Curtice, John K. (2001): The Rise of New Labour. Party Policies and Voter Choices. Oxford, Oxford University Press.

Heffernan, Richard (2001): New Labour and Thatcherism. Political Change in Britain. Basingstoke, Palgrave.

Heinisch, Reinhard (2003): Success in Opposition - Failure in Government: Explaining the Performance of Right-wing Populist Parties in Public Office, in: West European Politics 26(3), pp. 91-130.

Helms, Ludger (2006): Das Parteiensystem Großbritanniens. In: Niedermayer, Oskar, Stöss, Richard \& Haas, Melanie (eds.): Die Parteiensysteme Westeuropas. Wiesbaden, VS Verlag für Sozialwissenschaften. pp. 213-233.

Hewitt, Martin (2002): New Labour and the Redefinition of Social Security. In: Powell, Martin (ed.): Evaluating New Labour's Welfare Reforms. Bristol, Policy Press. pp. 189-209.

Hibbs, Douglas A. (1977): Political Parties and Macroeconomic Policy, in: American Political Science Review 71(4), pp. 1467-1487.

Hill, Michael (1993). The Welfare State in Britain. A Political History Since 1945. Aldershot, Edward Elgar.

Hort, Sven E.O. (2001): Sweden - Still a Civilized Version of Workfare? In: Gilbert, Neil \& Van Voorhis, Rebecca A. (eds.): Activating the Unemployed: A Comparative Appraisal of Work-Oriented Policies. New Brunswick \& London, Transaction Publishers. pp. 243-266.

Houtman, Dick, Achterberg, Peter \& Derks, Anton (2008): Farewell to the Leftist Working Class. New Brunswick, Transaction Publishers. 
Huber, Evelyne \& Stephens, John D. (1998): Internationalization and the Social Democratic Model: Crisis and Future Prospects, in: Comparative Political Studies 31(3), pp. 353-397.

Huber, Evelyne \& Stephens, John D. (2001): Development and Crisis of the Welfare State. Parties and Policies in Global Markets. Chicago \& London, University of Chicago Press.

Huckfeldt, Robert \& Kohfeld, Carol Weitzel (1989): Race and the Decline of Class in American Politics. Urbana \& Chicago, University of Illinois Press.

Huo, Jingjing (2009): Third Way Reforms. Social Democracy after the Golden Age. Cambridge, Cambridge University Press.

Huo, Jingjing, Nelson, Moira \& Stephens, John D. (2008): Decommodification and Activation in Social Democratic Policy: Resolving the Paradox, in: Journal of European Social Policy 18(1), pp. 5-20.

Immergut, Ellen M. (2002): The Swedish Constitution and Social Democratic Power: Measuring the Mechanical Effect of a Political Institution, in: Scandinavian Political Studies 25(3), pp. 231-257.

Immergut, Ellen M. \& Jochem, Sven (2006): The Political Frame for Negotiated Capitalism: Electoral Reform and the Politics of Crisis in Japan and Sweden, in: Governance 19(1), pp. 99-133.

Inglehart, Ronald (1984): The Changing Structure of Political Cleavages in Western Society. In: Dalton, Russell J., Flanagan, Scott J. \& Beck, Paul A. (eds.): Electoral Change in Advanced Industrial Democracies. Realignment or Dealignment. Princeton, Princeton University Press. pp. 25-69.

Inglehart, Ronald (1990): Culture Shift in Advanced Industrial Society. Princeton, Princeton University Press.

Inglehart, Ronald \& Rabier, Jacques-René (1986): Political Realignment in Advanced Industrial Society: From Class-based Politics to Qualityof-Life Politics, in: Government and Opposition 21(4), pp. 456-479.

Inglehart, Ronald \& Norris, Pippa (200o): The Developmental Theory of the Gender Gap: Women's and Men's Voting Behaviour in Global Perspective, in: International Political Science Review 21(4), pp. 441463.

Iversen, Torben (2005): Capitalism, Democracy, and Welfare. Cambridge, Cambridge University Press.

Jesse, Eckhard (2005): Die sächsische Landtagswahl vom 19. September 2004: Debakel für CDU und SPD gleichermaßen, in: Zeitschrift für Parlamentsfragen 36(1), pp. 64-80. 
Jesse, Eckhard (2006): Parteiensystem im Wandel? Das deutsche Parteiensystem vor und nach der Bundestagswahl 2005. In: Jesse, Eckhard \& Sturm, Roland (eds.): Bilanz der Bundestagswahl 2005: Voraussetzungen, Ergebnisse, Folgen. Wiesbaden, Verlag für Sozialwissenschaften. pp. 21-41.

Jung, Matthias, Schroth, Yvonne \& Wolf, Andrea (2010): Wählerverhalten und Wahlergebnis. Regierungswechsel ohne Wechselstimmung. In: Korte, Karl-Rudolf (Ed.): Die Bundestagswahl 2009. Analysen der Wahl-, Parteien-, Kommunikations- und Regierungsforschung. Wiesbaden, VS-Verlag. pp. 35-47.

Karreth, Johannes, Polk, Jonathan T. \& Allen, Christopher S. (2012): Catchall or Catch and Release? The Electoral Consequences of Social Democratic Parties' March to the Middle in Western Europe. Forthcoming in Comparative Political Studies, University of Georgia.

Karvonen, Lauri (1996): Christian Parties in Scandinavia: Victory over the Windmills? In: Hanley, David (ed.): Christian Democracy in Europe. A Comparative Perspective. London, Pinter. pp. 121-141.

Kedar, Orit (2005): When Moderate Voters Prefer Extreme Parties: Policy Balancing in Parliamentary Elections, in: American Political Science Review 99(2), pp. 185-199.

Keman, Hans (1988): The Development Toward Surplus Welfare: Social Democratic Politics and Policies in Advanced Capitalist Democracies (1965-1984). Amsterdam, CT Press.

Keman, Hans (1993): Theoretical Approaches to Social Democracy, in: Journal of Theoretical Politics 5(3), pp. 291-316.

Keman, Hans (2011): Third Ways and Social Democracy: The Right Way to Go?, in: British Journal of Political Science 41(3), pp. 671-68o, DOI:10.1017/Sooo7123410000475.

Keman, Hans, van Kersbergen, Kees \& Vis, Barbara (2006): Political Parties and New Social Risks: The Double Backlash against Social Democracy and Christian Democracy. In: Armingeon, Klaus \& Bonoli, Giuliano (eds.): The Politics of Post-Industrial Welfare States. Adapting Post-war Social Policies to New Social Risks. London \& New York, Routledge. pp. 27-51.

Kemmerling, Achim \& Bruttel, Oliver (2006): 'New Politics' in German Labour Market Policy? The implications of the recent Hartz Reforms for the German Welfare State, in: West European Politics 29(1), pp. 90-112. 
King, Desmond S. \& Wickham-Jones, Mark (1990): Review Article: Social Democracy and Rational Workers, in: British Journal of Political Science 20(3), pp. 387-413.

King, Gary, Keohane, Robert O. \& Verba, Sidney (1994): Designing Social Inquiry. Scientific Inference in Qualitative Research. Princeton, Princeton University Press.

King, Gary, Tomz, Michael \& Wittenberg, Jason (2000): Making the Most of Statistical Analyses: Improving Interpretation and Presentation, in: American Journal of Political Science 44(2), pp. 347-361.

Kitschelt, Herbert (1994): The Transformation of European Social Democracy. New York, Cambridge University Press.

Kitschelt, Herbert [in collaboration with Anthony J. McGann] (1997): The Radical Right in Western Europe. A Comparative Analysis. Ann Arbor, Michigan University Press.

Kitschelt, Herbert (1999): European Social Democracy between Political Economy and Electoral Competition. In: Kitschelt, Herbert, Lange, Peter, Marks, Gary \& Stephens, John D. (eds.): Continuity and Change in Contemporary Capitalism. Cambridge, Cambridge University Press. pp. 317-345.

Kitschelt, Herbert (2001a): Partisan Competition and Welfare State Retrenchment, When Do Politicians Choose Unpopular Policies? In: Pierson, Paul (ed.): The New Politics of the Welfare State. Oxford, Oxford University Press. pp. 265-302.

Kitschelt, Herbert (2001b): Politische Konfliktlinien in westlichen Demokratien: Ethnisch-kulturelle und wirtschaftliche Verteilungskonflikte, in: Loch, Dietmar \& Heitmeyer, Wilhelm (eds.): Schattenseiten der Globalisierung. Rechtsradikalismus, Rechtspopulismus und separatistischer Regionalismus in westlichen Demokratien. pp. 418-442.

Kitschelt, Herbert (2003): Political-Economic Context and Partisan Strategies in the German Federal Elections, 1990-2002, in: West European Politics 26(4), Special Issue on Germany, pp. 125-152.

Kitschelt, Herbert (2004): Diversification and Reconfiguration of Party Systems in Postindustrial Democracies. Bonn, Friedrich Ebert-Stiftung.

Kitschelt, Herbert (2007): Growth and Persistence of the Radical Right in Postindustrial Democracies: Advances and Challenges in Comparative Research, in: West European Politics 3o(5), pp. 1176-1206.

Kitschelt, Herbert \& Rehm, Philipp (2005): Work, Family, and Politics Foundations of Electoral Partisan Alignments in Postindustrial Democracies. Paper presented at the Annual Meeting of the American 
Political Science Association, Marriott Wardman Park, Omni Shoreham, Washington Hilton, Washington, DC, 1 September, 2005.

Kitschelt, Herbert \& Rehm, Philipp (2006): New Social Risk and Political Preferences. In: Armingeon, Klaus \& Bonoli, Giuliano (eds.): The Politics of Post-Industrial Welfare States. Adapting Post-war Social Policies to New Social Risks. London \& New York, Routledge. pp. 53-82.

Klitgaard, Michael Baggesen (2002): Når Forandringer Stabiliserer: Skandinaviske Velfærdsstatsreformer i 199o'erne, in: Politica 34(2), pp. 186-202.

Klitgaard, Michael Baggesen (2007): Why Are They Doing It? Social Democracy and Market-oriented Welfare State Reforms, in: West European Politics 3o(1), pp. 172-194.

Knutsen, Oddbjørn (2006): Class Voting in Western Europe. A Comparative Longitudinal Study. Oxford, Lexington Books.

Kornelius, Bernhard \& Roth, Dieter (2007): Bundestagswahl 2005: Rot-Grün abgewählt. Verlierer bilden die Regierung. In: Egle, Christoph \& Zohlndörfer, Reimut (eds.): Ende des rot-grünen Projektes. Eine Bilanz der Regierung Schröder. Wiesbaden, Verlag für Sozialwissenschaften. pp. 29-59.

Korpi, Walter (1983): The Democratic Class Struggle. London, Routledge and Kegan Poul.

Korpi, Walter (2006): Power Resources and Employer-centered Approaches in Explanations of Welfare States and Varieties of Capitalism, in: World Politics 58(2), pp. 167-206.

Korpi, Walter \& Palme, Joakim (1998): The Paradox of Redistribution and Strategies of Equality: Welfare State Institutions, Inequality, and Poverty in the Western Countries, in: American Sociological Review 63(5), pp. 661-687.

Korpi, Walter \& Palme, Joakim (2003): New Politics and Class Politics in the Context of Austerity and Globalization: Welfare State Regress in 18 Countries, 1975-1995, in: American Political Science Review 97(3), pp. 425-446.

Kriesi, Hanspeter, Grande, Edgar, Lachat, Romain, Dolezal, Martin, Bornschier, Simon \& Frey, Timotheos (2008): West European Politics in the Age of Globalization. Cambridge, Cambridge University Press.

Kriesi, Hanspeter \& Frey, Timotheos (2008): The United Kingdom: Moving Parties in a Stable Configuration. In: Kriesi, Hanspeter et al. (eds.), European Politics in the Age of Globalization. Cambridge, Cambridge University Press. pp. 183-207.

Lachmann, Günther (2010): Der Große Selbstbetrug einer siechen SPD, in: Die Welt, 12. November 2010. 
Leibfried, Stephan \& Obinger, Herbert (2003): The State of the Welfare State: German Social Policy between Macroeconomic Retrenchment and Microeconomic Recalibration, in: West European Politics 26(4), Special Issue on Germany, pp. 199-218.

Lindbom, Anders (2001): Dismantling the Social Democratic Welfare Model? Has the Swedish Welfare Lost its Defining Characteristics?, in: Scandinavian Political Studies 24(3), pp. 171-193.

Lindbom, Anders (2002): Den Svenska Välfärdsstaten under 1990-talet. Vad kan Danmark lärä av de Svenska Erfarenheterna?, in: Politica, 34(1), pp. 53-67.

Lindbom, Anders (2007): Obfuscating Retrenchment: Swedish Welfare Policy in the 1990s, in: Journal of Public Policy, 27(2), pp. 129-150.

Lindbom, Anders (2008): The Swedish Conservative Party and the Welfare State: Institutional Change and Adapting Preferences, in: Government and Opposition 43(4), pp. 539-56o.

Lindvall, Johannes (2010): Mass Unemployment and the State. Oxford, Oxford University Press.

Lindvall, Johannes \& Rueda, David (2012): Insider-Outsider Politics: Party Strategies and Political Behavior in Sweden. In: Emmenegger, Patrick, Häusermann, Silja, Palier, Bruno \& Seeleib-Kaiser, Martin (eds.): The Age of Dualization: Structures, Policies, Politics. New York, Oxford University Press. pp. 277-303.

Lipset, Seymour Martin (1981 [1960]): Political Man: The Social Bases of Politics. 2nd Edition. Baltimore, Johns Hopkins University Press.

Long, J. Scott \& Freese, Jeremy (2006): Regression Models for Categorical Dependent Variables Using Stata. College Station, Texas, Stata Press. Lynch, Philip \& Garner, Robert (2005): The Changing Party System, in: Parliamentary Affairs 58(3), pp. 533-554.

Madeley, John T.S. (2003): 'The Swedish Model is Dead! Long Live the Swedish Model!' The 2002 Riksdag Election, in: West European Politics 26(2), pp. 165-173.

Mandelson, Peter (2010): The Third Man. Life at the Heart of New Labour. London, Harper Press.

Manow, Philip (2007): Wahlregeln, Klassenkoalitionen und Wohlfahrtsstaatsregime - oder: wie man Esping-Andersen mit Rokkan erklären kann, in: Zeitschrift für Soziologie 36(6), pp. 414-430.

Manza, Jeff, Hout, Michael \& Brooks, Clem (1995): Class Voting in Capitalist Democracies since World War II: Dealignment, Realignment or Trendless Fluctuation?, in: Annual Review of Sociology 21: 137-62. 
March, Luke \& Mudde, Cas (2005): What's Left of the Radical Left? The European Radical Left After 1989: Decline and Mutation, in: Comparative European Politics 3(1), pp. 23-49.

Marshall, T.H. (1950): Citizenship and Social Class. Cambridge, Cambridge University Press.

Menz, Georg (2010): After Agenda 2010 is before the Elections: Consolidation, Dissent, and the Politics of German Labour Market Policy under the Grand Coalition, in: German Politics 19(3), pp. 446-459.

Merkel, Wolfgang, Egle, Christoph, Henkes, Christian, Ostheim, Tobias \& Petring, Alexander (2006): Die Reformfähigkeit der Sozialdemokratie. Herausforderungen und Bilanz der Regierungspolitik in Westeuropa. Wiesbaden, VS Verlag für Sozialwissenschaften.

Merkel, Wolfgang, Petring, Alexander, Henkes, Christian \& Egle, Christoph (2008): Social Democracy in Power. The Capacity to Reform. London \& New York, Routledge.

Moderat.se: Nya Moderaterna. Accessed at: www.moderat.se/web/Hem. aspx.

Mortensen, Hans (2008): Tid til Forvandling. Venstres Vej til Magten. Copenhagen, Gyldendal.

Mortensen, Hans (2011): Den Røde Tråd. SF og Vejen til Magten. Copenhagen, Lindhardt \& Ringhof.

Müller, Walter (1999): Class Cleavages in Party Preferences in Germany - Old and New. In: Evans, Geoffrey (ed.): The End of Class Politics? Oxford, Oxford University Press. pp. 137-180.

Neugebauer, Gero \& Stöss, Richard (1999): Nach der Bundestagswahl 1998: Die PDS in stabiler Seitenlage. In: Niedermayer, Oskar (ed.): Die Parteien nach der Bundestagswahl 1998. Opladen, Leske + Budrich. pp. 119-140.

Niedermayer, Oskar (2002): Nach der Vereinigung: Der Trend zum fluiden Fünfparteiensystem. In: Gabriel, Oscar, Niedermayer, Oskar \& Stöss, Richard (eds.): Parteiendemokratie in Deutschland. 2. Aktualisierte und erweiterte Auflage. Wiesbaden, Westdeutscher Verlag. pp. 107-127.

Niedermayer, Oskar (2003): Die Entwicklung des deutschen Parteiensystems bis nach der Bundestagswahl 2002. In: Niedermayer, Oskar (ed.): Die Parteien nach der Bundestagswahl 2002. Opladen, Leske + Budrich. pp. 9-41.

Niedermayer, Oskar (2005): Die brandenburgische Landtagswahl vom 19. September 2004: Reaktionen der Wähler auf Hartz IV, in: Zeitschrift für Parlamentsfragen 36(1), pp. 64-80. 
Niedermayer, Oskar (2006): Das Parteiensystem Deutschlands. In: Niedermayer, Oskar, Stöss, Richard \& Haas, Melanie (eds.): Die Parteiensysteme Westeuropas. Wiesbaden, VS Verlag für Sozialwissenschaften. pp. 109-133.

Niedermayer, Oskar \& Richard Stöss (2007): Die Berliner Abgeordnetenhauswahl vom 17. September 2006: Ein 'Weiter so' trotz herber Verluste des Koalitionspartners, in: Zeitschrift für Parlamentsfragen 38(1), pp. 84-100.

Nielsen, Hans Jørgen (1999): The Danish Election 1998, in: Scandinavian Political Studies 22(1), pp. 67-81.

Norris, Pippa \& Wlezien, Christopher (2005): Introduction. The Third Blair Victory: How and Why?, in: Parliamentary Affairs 58(4), pp. 657-683.

Norton, Edward C., Wang, Hua \& Ai, Chunrong (2004): Computing Interaction Effects and Standard Errors in Logit and Probit Models, in: The Stata Journal 4(2), pp. 154-167.

Notermans, Ton (2006): Money, Markets, and the State: Social Democratic Economic Policies Since 1918. Cambridge \& New York, Cambridge University Press.

OECD (1999): Benefit Systems and Work Incentives. Paris, OeCD Publications.

OECD (200o): Reforms for an Ageing Society. Paris, OECD Publications.

OECD (2010a): OECD Summary Measure of Benefit Entitlements. Accessed at: www.OECD.org/els/social/workincentives.

OECD (2010b): Net Replacement Rate for Long-term Unemployed. Accessed at: www.OECD.org/els/social/workincentives.

OECD (various years): Benefits and Wages. OECD Indicators. Paris, OECD Publications.

Oesch, Daniel (2006): Redrawing the Class Map. Stratification and Institutions in Britain, Germany, Sweden and Switzerland. Basingstoke, Palgrave Macmillan.

Olsen, Jonathan (2007): The Merger of the PDS and WASG: From Eastern German Regional Party to National Radical Left Party?, in: German Politics 16(2), pp. 205-221.

Olsson, Sven E. (1990): Social Policy and Welfare State in Sweden. Lund, Arkiv Förlag.

Oscarsson, Henrik \& Holmberg, Sören (2008): Regeringsskifte. Valjärna och Valet 20o6. Stockholm, Norstedts Juridik.

Oskarson, Maria (1994): Klassröstning i Sverige. Stockholm, Nerenius \& Santérud Förlag. 
Padgett, Stephen (2004): Welfare Bias in the Party System: A Neo-Downsian Explanation for Gridlock in Economic Reform, in: German Politics 13(2), pp. 360-383.

Padgett, Stephen (2005): The Party Politics of Economic Reform: Public Opinion, Party Positions and Partisan Cleavages, in: German Politics 14(2), pp. 248-274.

Palme, Joakim \& Wennemo, Irene (1998): Swedish Social Security in the 1990s: Reform and Retrenchment. Stockholm, Välfärdsprojektet.

Palme, Joakim, Bergmark, Åke, Bäckman, Olof, Estrada, Felipe, Fritzell, Johan, Lundberg, Olle, Sjöberg, Ola \& Szebehely, Marta (2002): Welfare Trends in Sweden: Balancing the Books for the 199os, in: Journal of European Social Policy 12(4), pp. 329-346.

Patton, David F. (2006): Germany's Left Party.PDS and the 'Vacuum Thesis': From Regional Milieu Party to Left Alternative?, in: Journal of Communist Studies and Transition Politics 22(2), pp. 206-227.

Petersen, Klaus (1998): Legitimität und Krise: die politische Geschichte des dänischen Wohlfahrtsstates 1945-1973. Berlin, Berlin Verlag A. Spitz.

Petersen, Klaus (2001): Programmeret til Velfærd? Om Ideologi og Velfærdspolitik i Socialdemokratiske Partiprogrammer efter 1945, in: Arbejderhistorie 2/2001, pp. 23-51.

Petrocik, John R. (1996): Issue Ownership in Presidential Elections with a 1980 Case Study, in: American Journal of Political Science 40(3), pp. 825-850.

Picot, Georg (2009): Party Competition and Reforms of Unemployment Benefits in Germany: How a Small Change in Electoral Demand Can Make a Big Difference, in: German Politics 18(2), pp. 155-179.

Pierson, Paul (1994): Dismantling the Welfare State: Reagan, Thatcher, and the Politics of Retrenchment in Britain and the United States. Cambridge, Cambridge University Press.

Pierson, Paul (1996): The New Politics of the Welfare State, in: World Politics 48(2), pp. 143-179.

Pierson, Paul (2001): Coping with Permanent Austerity. Welfare State Restructuring in Affluent Democracies, in: Pierson, Paul (ed.): The New Politics of the Welfare State. Oxford, Oxford University Press. pp. 410-456.

Plovsing, Jan (2007): Velfardsstat og Socialpolitik. 2nd ed. Copenhagen, Handelshøjskolen Forlag.

Pontusson, Jonas (1992a): At the End of the Third Road: Swedish Social Democracy in Crisis, in: Politics E Society 20(3), pp. 305-332.

Pontusson, Jonas (1992b): The Limits of Social Democracy. Investment Politics in Sweden. Ithaca \& London, Cornell University Press. 
Pontusson, Jonas (1995): Explaining the Decline of European Social Democracy: The Role of Structural Economic Change, in: World Politics 47(4), pp. 495-533.

Powell, Martin (2004): Social Democracy in Europe. Renewal or Retreat? in: Bonoli, Guiliano \& Powell, Martin (eds.): Social Democratic Party Policies in Contemporary Europe. London \& New York, Routledge. pp.1-2o.

Przeworski, Adam (1980): Social Democracy as a Historical Phenomenon, in: New Left Review 122(July-August), pp. 27-58.

Przeworski, Adam (1985): Capitalism and Social Democracy. Cambridge, Cambridge University Press.

Przeworski, Adam \& Sprague, John (1986): Paper Stones. A History of Electoral Socialism. Chicago, University of Chicago Press.

Qvortrup, Mads (2002): Election Report - The Emperor's New Clothes: The Danish General Election 20 November 2001, in: West European Politics 25(2), 205-211.

Randall, Nick \& Sloam, James (2009): New Labour, the Third Way and Social Democracy: An Ideological Assesment. In: Casey, Terrence (ed.): The Blair Legacy. Politics, Policy, Governance, and Foreign Affairs. Basingstoke \& New York, Macmillan. pp. 94-106.

Raschke, Joachim (2010): Zerfallsphase des Schröder-Zyklus. Die SPD 2005-2009. In: Egle, Christoph \& Zohlnhöfer, Reimut (eds.): Die zweite Große Koalition. Eine Bilanz der Regierung Merkel 2005-20o9. Wiesbaden, VS Verlag. pp. 69-98.

Redder, Gitte (2010): Arbejderne Strømmer Tilbage til Rød Blok, in: Ugebrevet A4, 2010, Nr. 31, pp. 8-11.

Ross, Fiona (2000): Beyond Left and Right: The New Partisan Politics of Welfare, in: Governance 13(2), pp. 155-183.

Rueda, David (2005): Insider-Outsider Politics in Industrialized Democracies: The Challenge to Political Parties, in: American Political Science Review 99(1), pp. 61-74.

Rueda, David (2006): Social Democracy and Active Labour-Market Policies: Insiders, Outsiders and the Politics of Employment Protection, in: British Journal of Political Science 36(3), pp. 385-406.

Rueda, David (2007): Social Democracy Inside Out. Partisanship E Labor Market Policy in Industrialized Democracies. Oxford, Oxford University Press. Russell, Andrew \& Cutts, David (2009): The Liberal Democrats after Blair. In: Casey, Terrence (ed.): The Blair Legacy. Politics, Policy, Governance, and Foreign Affairs. Basingstoke \& New York, Macmillan. pp. 65-79. 
Rydgren, Jens (2002): Radical Right Populism in Sweden: Still a Failure, But for How Long?, in: Scandinavian Political Studies 25(1), pp. 27-56. Rydgren, Jens (2004): Explaining the Emergence of Radical Right-Wing Populist Parties: The Case of Denmark, in: West European Politics 27(3), pp. 474-502.

SAP (1960): Program för Sveriges Socialdemokratiska Arbetareparti.

SAP (1975): Socialdemokraterna, Program.

SAP (1990): Socialdemokraternas Partiprogram.

SAP (2001): Partiprogram för Socialdemokraterna 2001.

Särlvik, Bo (2002): Party and Electoral System in Sweden. In: Grofman, Bernard \& Lijphart, Arend (eds.): The Evolution of Electoral and Party Systems in the Nordic Countries. New York, Agathon Press. pp. 225-269. Sarrazin, Thilo (2010): Deutschland schafft sich ab. Wie wir unser Land auf Spiel setzen. Berlin, Deutsche Verlags-Anstalt.

Schäfer, Armin (2007): Die Reform des Sozialstaats und das deutsche Parteiensystem: Abschied von den Volksparteien?, in: Zeitschrift für Parlamentsfragen 38(3), pp. 648-666.

Scheuregger, Daniel \& Spier, Tim (2007): Working-class Authoritarianism und die Wahl Rechtspopulistischer Parteien, in: Kölner Zeitschrift für Soziologie und Sozialpsychologie 59(1), pp. 59-80.

Schmidt, Manfred G. (1982): Wohlfahrtsstaatliche Politik unter Bürgerlichen und Sozialdemokratischen Regierungen. Ein Internationaler Vergleich. Frankfurt a.M., Campus Verlag.

Schmidt, Manfred G. (2003): Rot-grüne Sozialpolitik. In: Egle, Christoph, Ostheim, Tobias \& Zohlnhöfer, Reimut (eds.): Das Rot-grüne Projekt. Eine Bilanz der Regierung Schröder 1998-2002. Wiesbaden, Westdeutscher Verlag. pp. 215-238.

Schmidt, Manfred G. (2006): Wenn zwei Sozialstaatsparteien konkurrieren: Sozialpolitik in Deutschland. In: Schmidt, Manfred G. \& Zohlnhöfer, Reimut (eds.): Regieren in der Bundesrepublik Deutschland. Innen und Außenpolitik seit 1949. Wiesbaden, VS Verlag für Sozialwissenschaften. pp. 137-157.

Schmidt, Manfred G. (2010): Die Sozialpolitik der zweiten Großen Koalition (2005 bis 2009). In: Egle, Christoph \& Zohlnhöfer, Reimut (eds.): Die zweite Große Koalition. Eine Bilanz der Regierung Merkel 20052009. Wiesbaden, VS Verlag. pp. 302-326.

Scruggs, Lyle (2006): Welfare State Entitlements Data Set: A Comparative Institutional Analysis of Eighteen Welfare States, Version 1.2. Available at: www.sp.uconn.edu/ scruggs/ wp.htm. 
Scruggs, Lyle (2007): Welfare State Generosity Across Space and Time. In: Clasen, Jochen \& Siegel, Nico A. (eds.): Investigating Welfare State Change. The 'Dependent Variable Problem' in Comparative Analysis. Cheltenham, Edward Elgar. pp. 133-165.

Scruggs, Lyle \& Allan, James (2006): Welfare-state Decommodification in 18 OECD Countries: A Replication and Revision, in: Journal of European Social Policy 16(1), pp. 55-72.

SD (1961): Vejen Frem. Socialdemokratiets Principprogram 1961.

SD (1977): Solidaritet, Lighed og Trivsel. Socialdemokratiets 3. Principprogram.

SD (1992): Det Ny Århundrede. Socialdemokratiets Principprogram.

Shaw, Eric (2003): Britain: Left Abandoned? New Labour in Power, in: Parliamentary Affairs, 56(1), pp. 6-23.

Shaw, Eric (2007): Losing Labour's Soul? New Labour and the Blair Government 1997-2007. London \& New York, Routledge.

SPD (1959): Godesberger Programm. Grundsatzprogramm der Sozialdemokratischen Partei Deutschlands von 1959.

SPD (1989): Grundsatzprogramm der Sozialdemokratischen Partei Deutschlands, 1989.

Spier, Tim \& Wirries, Clemens (2007): Ausnahmeerscheinung oder Normalität? Linksparteien in Westeuropa. In: Spier, Tim, Butzlaff, Felix, Micus, Matthias \& Walter, Franz (eds.): Die Linkspartei. Zeitgemäße Idee oder Bündnis ohne Zukunft? Wiesbaden, Verlag für Sozialwissenschaften. pp. 71-116.

Starke, Peter (2006): The Politics of Welfare State Retrenchment: A Literature Review, in: Social Policy \& Administration, 4o(1), pp. 104-120.

Starke, Peter (2008): Radical Welfare State Retrenchment. A Comparative Analysis. Houndmills, Basingstoke, Hampshire and New York, Palgrave Macmillan.

Statistiska centralbyrån (2004): Riksdagsvalen 1973-2002. Sveriges Officiella Statistik, Statistiska Meddelanden ME 11 SM 0401. Accessed at: www.scb.se/Pages/PublishingCalendarViewInfo 259923. aspx?PublObjId $=2460$.

Steffen, Christian (2006): Die Parteiensysteme Dänemarks, Norwegens und Schwedens. In: Niedermayer, Oskar, Stöss, Richard \& Haas, Melanie (eds.): Die Parteiensysteme Westeuropas. Wiesbaden, VS Verlag für Sozialwissenschaften. pp. 67-108.

Stjernø, Steinar (2005): Solidarity in Europe. The History of an Idea. Cambridge, Cambridge University Press.

Stöss, Richard (2006): Rechtsextreme Parteien in Westeuropa. In: Nieder- 
mayer, Oskar, Stöss, Richard \& Haas, Melanie (eds.): Die Parteiensysteme Westeuropas. Wiesbaden, VS Verlag für Sozialwissenschaften. pp. 521-563.

Streeck, Wolfgang \& Trampusch, Christine (2005): Economic Reform and the Political Economy of the German Welfare State, in: German Politics 14(2), pp. 174-195.

Stubager, Rune (2006): The Education Cleavage: New Politics in Denmark. Aarhus, Politica.

Svallfors, Stefan (2006): The Moral Economy of Class. Class and Attitudes in Comparative Perspective. Stanford, Stanford University Press.

Svallfors, Stefan (2007): Class and Attitudes to Market Inequality: A Comparison of Sweden, Britain, Germany, and the United States. In: Svallfors, Stefan (ed.): The Political Sociology of the Welfare State. Institutions, Social Cleavages, and Orientations. Stanford, Stanford University Press. pp. 189-222.

Svensson, Torsten (1990): Tjänstemännen och den Socialdemokratiska Strategin, in: Statsvetenskaplig Tidsskrift, 93(1), pp. 1-23.

Svensson, Torsten (1994): Socialdemokratins Dominans. En Studie av den Svenska Socialdemokratins Partistrategi. Uppsala, Statsvetenskapliga Föreningen.

Tawney, R.H. (1964 [1931]): Equality. London, Allen \& Unwin.

Taylor-Gooby, Peter, Larsen, Trine \& Kananen, Johannes (2004): Market Means and Welfare Ends: The UK Welfare State Experiment, in: Journal of Social Policy 33(4), pp. 573-592.

Therborn, Göran (1987): Welfare States and Capitalist Markets, in: Acta Sociologica 3o(3/4), pp. 237-254.

Timonen, Virpi (2003): Restructuring the Welfare State. Globalization and Social Policy Reform in Finland and Sweden. Cheltenham, Edward Elgar.

Titmuss, Richard (1958): Essays on the Welfare State. London, Allen \& Unwin. Tomz, Michael, Wittenberg, Jason \& King, Gary (2003): Clarify: Software for Interpreting and Presenting Statistical Results. Version 2.1. Stanford University, University of Wisconsin, and Harvard University. January 5. Available at http://gking.harvard.edu/.

Val.se (2010): Allmännna Val 20o6. Accessed at: www.val.se/tidigare_val/ val2006/index.html.

Van der Waal, Jeroen, Achterberg, Peter, Houtman, Dick, de Koster, Willem \& Manevska, Katerina (2007): 'Some are More Equal than Oth- 
ers': Economic Egalitarianism and Welfare Chauvinism in the Netherlands, in: Journal of European Social Policy 2o(4), pp. 350-363.

Van Kersbergen, Kees (1995): Social Capitalism. A Study of Christian Democracy and the Welfare State. London, Routledge.

Van Kersbergen, Kees (2002): The Politics of Welfare State Reform, in: Swiss Political Science Review 8(1), pp. 1-20.

Vis, Barbara (2009): Governments and Unpopular Social Policy Reform: Biting the Bullet or Steering Clear?, in: European Journal of Political Research, 48(1), pp. 31-57.

Vis, Barbara (2010): Politics of Risk Taking. Welfare State Reform in Advanced Democracies. Amsterdam, Amsterdam University Press.

Vis, Barbara, van Kersbergen, Kees \& Becker, Uwe (2008): The Politics of Welfare State Reform in the Netherlands: Explaining a Never-Ending Puzzle, in: Acta Politica, 43(2/3), pp. 333-356.

Volkens, Andrea (2004): Policy Changes of European Social Democrats, 1945-1998. In: Bonoli, Guiliano \& Powell, Martin (eds.): Social Democratic Party Policies in Contemporary Europe. London \& New York, Routledge. pp. 21-42.

Von Alemann, Ulrich (1999): Der Wahlsieg der SPD von 1998: Politische Achsenverschiebung oder glücklicher Ausreißer? In: Niedermayer, Oskar (ed.): Die Parteien nach der Bundestagswahl 1998. Opladen, Leske + Budrich. pp. 37-62.

Walker, Robert \& Wiseman, Michael (2003): Making Welfare Work: UK Activation Policies under New Labour, in: International Social Security Review 56(1), pp. 3-29.

Weakliem, David L. (1991): The Two Lefts? Occupation and Party Choice in France, Italy, and the Netherlands, in: American Journal of Sociology 96(6), pp. 1327-1361.

Weakliem, David L. \& Heath, Anthony F. (1994): Rational Choice and Class Voting, in: Rationality and Society 6(2), pp. 243-270.

Webb, Paul (2003): Parties and Party System: Prospects for Realignment. In: Parliamentary Affairs 56(3), pp. 283-296.

Webb, Paul (2005): The Continuing Advance of Minor Parties. In: Parliamentary Affairs 58(4), pp. 757-775.

Weber, Max (1920): Wirtschaft und Gesellschaft. Tübingen, Mohr.

Wehler, Hans-Ulrich (2008): Deutsche Gesellschaftsgeschichte. Fünfter Band: Bundesrepublik und DDR 1949-199o. Munich, C.H. Beck.

Werz, Nikolaus \& Schoon, Steffen (2007): Die mecklenburg-vorpommersche Landtagswahl vom 17. September 2006: Ein halber Regier- 
ungswechsel und das Ende des Dreiparteiensystems, in: Zeitschrift für Parlamentsfragen 38(1), pp. 67-83.

Wessels, Bernhard (2004): The German Party System: Developments After Unification. In: Reutter, Werner (ed.): Germany on the Road to 'Normalcy': Policies and Politics of the Red-Green Federal Government (1998-2002). pp. 47-65.

Zohlnhöfer, Reimut (2001): Parteien, Vetospieler und der Wettbewerb um Wählerstimmen: Die Arbeitsmarkt und Beschäftigungspolitik der Ära Kohl, in: Politische Vierteljahresschrift 42(4), pp. 655-682.

Zohlnhöfer, Reimut (2004): Die Wirtschaftspolitik der rot-grünen Koalition: Ende des Reformstaus?, in: Zeitschrift für Politikwissenschaft 14(2), pp. 381-402.

Zohlnhöfer, Reimut \& Egle, Christoph (2007): Der Episode zweitet Teil - ein Überblick über die 15. Legislaturperiode. In: Egle, Christoph \& Zohlndörfer, Reimut (eds.): Ende des rot-grünen Projektes. Eine Bilanz der Regierung Schröder. Wiesbaden, Verlag für Sozialwissenschaften. pp. 11-25. 



\section{Index}

Active labour market policies

(ALMPS) 36, 44-45, 66, 105, 109, 133, 153-156, 161-162, 164-165, 167, 171-172, 180, 203-204, 232, $247 \mathrm{n}$

Agenda 2010 30, 99, 106, 109, 112117, 124, 196

Åkesson, Jimmie 179

Arbeitslosengeld, ALG I, ALG II 104, 107-109, 116, 220-221, 242n

Arbeitslosenhilfe 104, 107-108, 221

Arbetslivsutveckling 164

Arbetsmarknadsstyrelsen (AMS), National Labour Board in Sweden 154-155

ATP pension schemes (Denmark and Sweden) 129, 154, 157

Bildt, Carl 160

Bismarckian welfare provision/ state $82,104,107$

Blair, Tony $77,81,86,95,241 \mathrm{n}$

Blame-avoidance $42,125,192-196$, $242 \mathrm{n}$

Bundesanstalt für Arbeit/Bundesagentur für Arbeit 106, 242n

Callaghan, James 79

Compulsory voting 239n, 246n

Conditionality $36,44-45,70$, 82-84, 107-110, 115, 133-137, 155, $163-166,180,184-185$
Core constituency and conceptualisation thereof 46-50

Credibility of challengers, dirty hands $58-59,75,111-113,149$, 170, 188, 190-191, 199, 205, 243n

Creeping disentitlements 136

Efterløn/early retirement scheme in Denmark 129-130, 193 - and reform of $134,136,193$, 203, 208

Electoral consequences of reforms in other countries

Austria 58

The Netherlands 203, 207

New Zealand 195, 202-203

Norway 204

Electoral system 24, 28, 30, 33, $50-52,53,66,68,73-75,77,84-$ $85,87-88,94-97,158,185-188$, 192, 194, 201-202, 204, 211

Electoral system and non-voter trade-off $50-52,73,75,77,88$, 94-96, 185, 194, 201-202, 211-212, $246 n$

Eligibility criteria $44,70,105,108-$ 109, 115, 129, 133-136, 142, 154, 16o-166, 184-185, 203-204, 244n

Eligibility period(s) 43-44, 79, 82, 107-108, 129, 134-135, 141, 155, $161,163-165,171-172,233,242$ n$243 n$ 
Ellemann Jensen, Uffe 140

Feldt, Kjell-Olof 156, 159

Fogh Rasmussen, Anders 140

Folkepension (People's Pension in Denmark and Sweden) 129, 154, 160, 162

Forlig (cross-party settlement) 190

Førtidspension and reform of 24.4n

Ghent system of unemployment insurance 160

Giddens, Anthony 23, 33, 35, 37, 61, 197-198, 207, 212

Hartz, Peter 106

Hartz reforms 99-100, 106-109, 112-114, 121, 123-125, 189, 242n$243 n$

Heath, Edward (Ted) 79

Issue ownership 25, 42, 54, 196 Job-AQTIV legislation 105, 108, 118

Job-seekers Allowance (JSA) 82, 84

Kinnock, Neil 85

Kohl, Helmut 101, 102, 104-105

Labour market reform(s) under Third Way 45, 65, 69-72, 184

- in Denmark and attitudes towards 30, 58, 127, 132-138, 141-143, 148-150, 190, 193, 198-199, 244n

- in Germany and attitudes towards 99, 105-110, 114-116, 119, 122-123, 243n

- in Great Britain and attitudes towards 81-84, 185

- in Sweden and attitudes towards 160, 163-166, 171-172 Lafontaine, Oskar 103, 112, 126
Major, John $82-83$

Mandelson, Peter 208

National Health Service (NHS) 78

National Insurance 78,82

New Deal reforms (United Kingdom) 30, 77, 82-84, 90, 95, 185, 195

New Politics of the Welfare State 24, 28, 192-193, 195, 201, 205

Nixon-goes-to-China logic 25, 195-196

Nyrup Rasmussen, Poul 127, 132133, 138, 142, 147, 149-150, 186, 190, 193, 198

Party competition (and role of) $24-25,28,50,52,55,68,74,183$, $185,187,189,204-206$

- in Denmark 138-141

- in Germany 104, 110-113, $242 \mathrm{n}$

- in Sweden 167-170

- in the United Kingdom 81, 84-88, 95

Pensions and pension reform 78 79, 99-101, 105-106, 108, 113, 121, $123,129-130,154,157,160,162-$ $163,193,210,220,241 \mathrm{n}-242 \mathrm{n}$, 24.4n-245n

Reformstau (in Germany) 104 Reinfeldt, Fredrik 169, 179

Replacement rate(s) 39, 42-45, 70-71, 78-79, 83, 85, 101, 104105, 107, 109-110, 129, 133-134, 136-137, 155-156, 160-166, 177, 184, 240n, $244 \mathrm{n}$

Riester-Rente/Riester pension reform 105-106, 118, 193, $242 \mathrm{n}$

Riester, Walter 242n

Sahlin, Mona 179 
Sarrazin, Thilo 212

Schröder, Gerhard 58, 103, 105106, 111, 114-118, 124-125, 189, $193,196,241 n-243 n$

Smith, John 85

Social Assistance 107-108, 133, $135,162,167,209,221,245 \mathrm{n}$

Social investment state 44

State Earnings-Related Pension Scheme (SERPS) 79

Suitability criteria 43-44, 107-109, 114-116, 134-135, 141, 143

Thatcher, Margaret 83

Third Road (in Sweden) 156, 159160
Unemployment insurance $245 \mathrm{n}$

- in Denmark 129, 133-137

- in Germany 104, 106-107

- in Sweden 155, 160-161, 164, 165-166

- in the United Kingdom 8182,185

Utvecklingsgaranti $\quad 162,165$

Welfare state regime(s) 4o, 67-68

conservative 67-68, 104

liberal $67-68$

social democratic $67-68,104$

Wilson, Harold 79

Workfare 36, 153-155, 166-167, $18 \mathrm{o}, 184,247 \mathrm{n}$ 



\section{CHANGING WELFARE STATES}

\section{PREVIOUSLY PUBLISHED}

Jelle Visser and Anton Hemerijck, A Dutch Miracle. Job Growth, Welfare Reform and Corporatism in the Netherlands, 1997 ISBN 9789053562710

Christoffer Green-Pedersen, The Politics of Justification. Party Competition and Welfare-State Retrenchment in Denmark and the Netherlands from 1982 to 1998, 2002 ISBN 9789053565902

Jan Høgelund, In Search of Effective Disability Policy. Comparing the Developments and Outcomes of the Dutch and Danish Disability Policies, 2003 ISBN 9789053566442

Maurizio Ferrera and Elisabetta Gualmini, Rescued by Europe? Social and Labour Market Reforms from Maastricht to Berlusconi, 2004 ISBN 9789053566510

Martin Schludi, The Reform of Bismarckian Pension Systems. A Comparison of Pension Politics in Austria, France, Germany, Italy and Sweden, 2005 ISBN 9789053567401

Uwe Becker and Herman Schwartz (eds.), Employment 'Miracles'. A Critical Comparison of the Dutch, Scandinavian, Swiss, Australian and Irish Cases Versus Germany and the US, 2005 ISBN 9789053567555

Sanneke Kuipers, The Crisis Imperative. Crisis Rhetoric and Welfare State Reform in Belgium and the Netherlands in the Early 1990s, 2006 ISBN 9789053568088

Anke Hassel, Wage Setting, Social Pacts and the Euro. A New Role for the State, 2006 ISBN 9789053569191

Ive Marx, A New Social Question? On Minimum Income Protection in the Postindustrial Era, 2007 ISBN 9789053569252

Monique Kremer, How Welfare States Care. Culture, Gender and Parenting in Europe, 2007 ISBN 9789053569757

Sabina Stiller, Ideational Leadership in German Welfare State Reform. How Politicians and Policy Ideas Transform Resilient Institutions, 2010 ISBN 9789089641861 
Barbara Vis, Politics of Risk-taking. Welfare State Reform in Advanced Democracies, 2010 ISBN 9789089642271

Bruno Palier (ed.), A Long Goodbye to Bismarck? The Politics of Welfare Reform in Continental Europe, 2010 ISBN 9789089642349

J. Timo Weishaupt, From the Manpower Revolution to the Activation Paradigm. Explaining Institutional Continuity and Change in an Integrating Europe, 2011 ISBN 9789089642523

Uwe Becker (ed.), The Changing Political Economies of Small West European Countries, 2011 ISBN 9789089643315

Romke van der Veen, Mara Yerkes and Peter Achterberg (eds.): The Transformation of Solidarity. Changing Risks and the Future of the Welfare State, 2012 ISBN 9789089643834

Alexandre Afonso: Social Concertation in Times of Austerity. European Integration and the Politics of Labour Market Reforms in Austria and Switzerland, 2013 ISBN 9789089643957 
In all advanced Western nations, policy-makers have implemented encompassing welfare state reforms in recent decades breaking with past welfare arrangements. In particular, social democracy engaged in significant policy change under the Third Way paradigm and broke with its traditional reputation on welfare that had built the ties with the core constituency in the $20^{\text {th }}$ century.

The Electoral Consequences of Third Way Welfare State Reforms: Social Democracy's Transformation and its Political Costs provides a comparative study of the electoral consequences of Third Way welfare state reforms. The book demonstrates that Third Way reforms went against the social policy preferences of social democracy's core voters and indeed produced an electoral setback for social democrats at the ballots. Moreover, and accounting for cross-national variation, the analysis shows that the nature of the setback is contingent on the electoral system and the party competition social democrats face when reforming the welfare state.

Christoph Arndt is postdoctoral fellow in the Department of Political Science and Government at Aarhus University in Denmark.

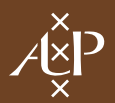

WWW.AUP.NL

Amsterdam University Press

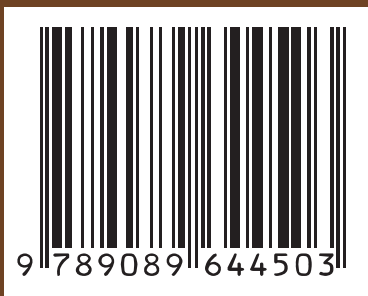

